U.S. Department of the Interior

U.S. Geological Survey

\title{
GEOHYDROLOGY AND GROUND-WATER QUALITY, BIG ELK CREEK BASIN, CHESTER COUNTY, PENNSYLVANIA, AND CECIL COUNTY, MARYLAND
}

by Ronald A. Sloto

Water-Resources Investigations Report 02-4057

In cooperation with

CHESTER COUNTY WATER RESOURCES AUTHORITY

and

CHESTER COUNTY HEALTH DEPARTMENT

New Cumberland, Pennsylvania 2002 


\section{U.S. DEPARTMENT OF THE INTERIOR \\ GALE A. NORTON, Secretary}

\section{U.S. GEOLOGICAL SURVEY}

Charles G. Groat, Director

For additional information write to:

District Chief

U.S. Geological Survey

215 Limekiln Road

New Cumberland, Pennsylvania 17070-2424

Email: dc_pa@usgs.gov

Internet Address: http://pa.water.usgs.gov
Copies of this report may be purchased from:

U.S. Geological Survey

Branch of Information Services

Box 25286

Denver Federal Center

Denver, Colorado 80225-0286

Telephone: 1-888-ASK-USGS 


\section{CONTENTS}

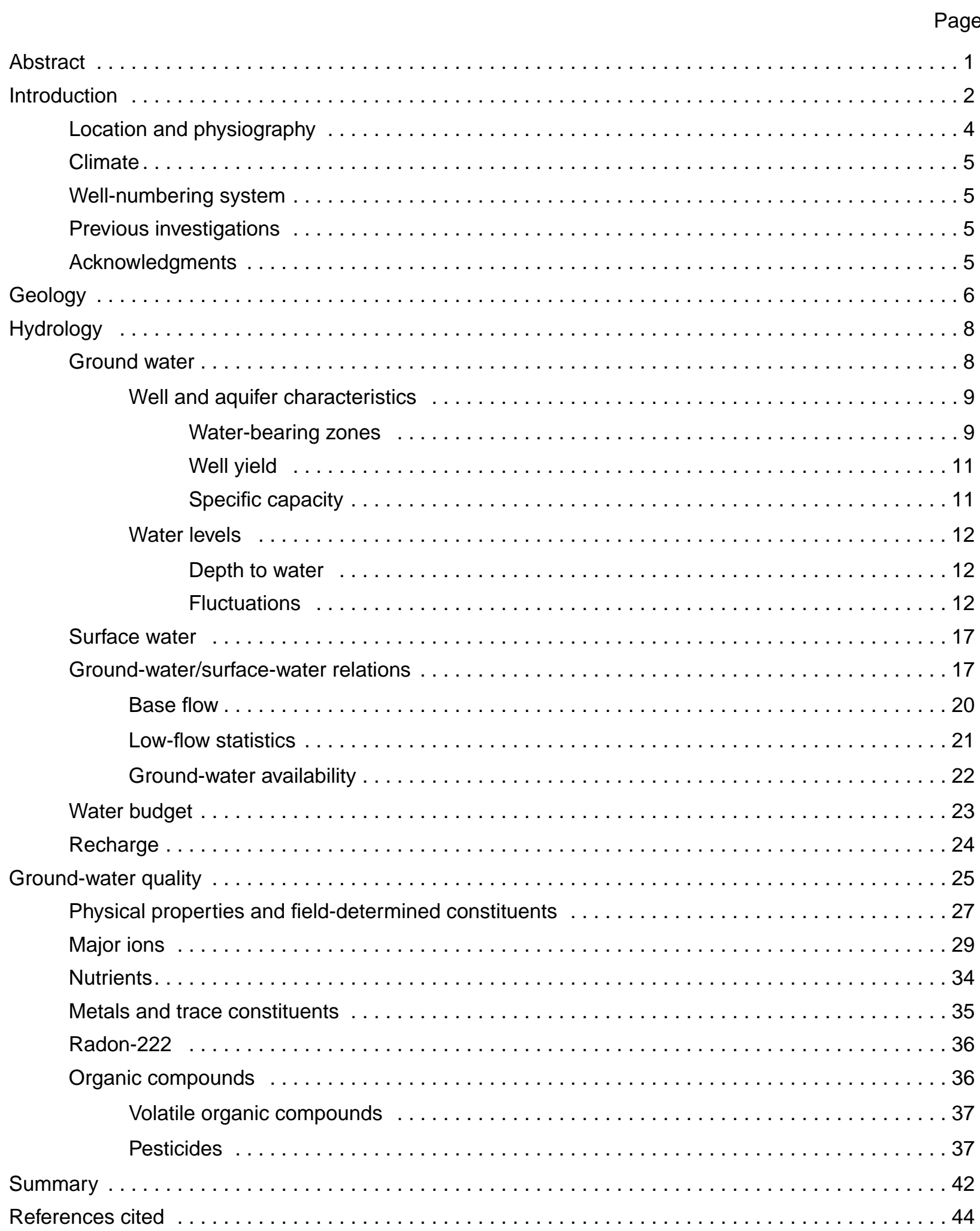




\section{ILLUSTRATIONS}

Page

Figures 1-2. Maps showing:

1. Location of the Big Elk Creek Basin, Pennsylvania and Maryland. . . . . . . . 3

2. The Big Elk Creek Basin study area, Pennsylvania and Maryland . . . . . . . 4

3. Generalized geologic map of the Big Elk Creek Basin, Pennsylvania and Maryland . . 6

4. Diagram showing wells in fractured rock $\ldots \ldots \ldots \ldots \ldots \ldots \ldots \ldots \ldots$

5. Map showing location of streamflow-measurement stations, observation wells, and precipitation gages in the Big Elk Creek Basin, Pennsylvania and Maryland . . . 14

6. Hydrographs showing depth to water in wells $\mathrm{CH}-5423, \mathrm{CH}-5428, \mathrm{CE} \mathrm{Ae} 8$, and CE Ae 9, 1998-99, Big Elk Creek Basin, Pennsylvania and Maryland . . . . . . 15

7. Hydrograph showing depth to water in well $\mathrm{CH}-254,1990-99$, Big Elk Creek Basin,

Chester County, Pennsylvania $\ldots \ldots \ldots \ldots \ldots \ldots \ldots \ldots \ldots \ldots \ldots \ldots \ldots \ldots \ldots \ldots \ldots$

8-10. Graphs showing:

8. Duration of mean daily flow of Big Elk Creek at Elk Mills, Maryland, water years 1933-99, and Little Elk Creek at Childs, Maryland,

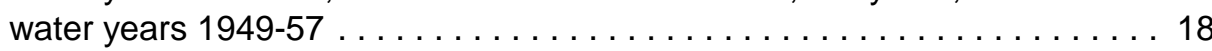

9. Relation among precipitation, ground-water levels, and streamflow, 1998-99, Big Elk Creek Basin, Pennsylvania and Maryland . . . . . . . . . . . 19

10. Cumulative annual base-flow frequency of Big Elk Creek at Elk Mills, Maryland, 1933-99, and Little Elk Creek at Childs, Maryland, 1949-57 . . . 21

11. Map showing location of wells sampled for water-quality analyses, Big Elk Creek

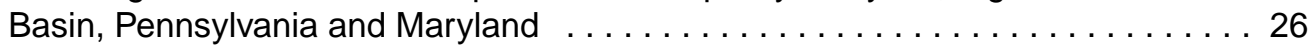

12. Graph showing relation between concentrations of sodium and chloride in ground water in the Big Elk Creek Basin, Pennsylvania and Maryland. . . . . . . 32

13. Piper diagram showing relative concentrations of major ions in ground water in the Big Elk Creek Basin, Pennsylvania . 


\section{TABLES}

\section{Page}

Table 1. Geologic units in the Big Elk Creek Basin, Pennsylvania and Maryland $\ldots \ldots \ldots \ldots 7$

2. Number of water-bearing zones reported per 100 feet of uncased borehole drilled in the Big Elk Creek Basin, Chester County, Pennsylvania . . . . . . . . . . . 10

3. Minimum, maximum, and median reported well yields for wells in the Big Elk Creek Basin, Chester County, Pennsylvania, and Cecil County, Maryland .......... 11

4. Minimum, maximum, and median reported specific capacity for wells in the Big Elk Creek Basin, Chester County, Pennsylvania, and Cecil County,

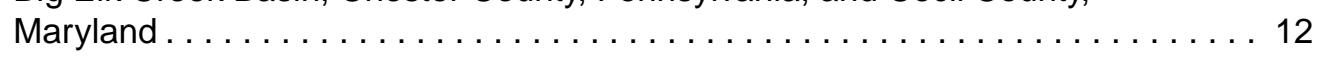

5. Minimum, maximum, and median reported depth to water in wells in the Big Elk Creek Basin, Chester County, Pennsylvania, and Cecil County, Maryland.... . 13

6. Annual streamflow and estimated annual base flow for Big Elk Creek and Little Elk Creek, Pennsylvania and Maryland, 1933-99 ............. 20

7. Low-flow statistics for streamflow-measurement station Big Elk Creek at Elk Mills, Maryland (station 01495000), based on log Pearson Type III frequency

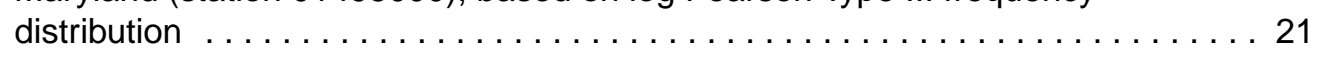

8. Ground-water availability in the Big Elk Creek Basin, Pennsylvania and Maryland. . . 22

9. Annual water budgets for the Big Elk Creek Basin, Pennsylvania and Maryland,

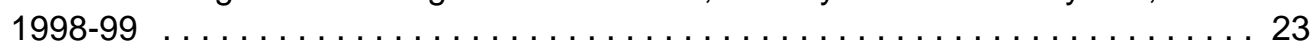

10. Estimated annual recharge for the Big Elk Creek Basin, Pennsylvania and

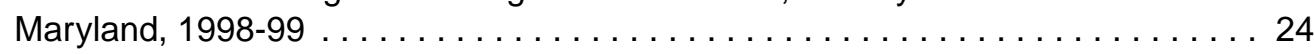

11. Summary of physical properties and field-determined constituents for water samples from wells in the Big Elk Creek Basin, Pennsylvania and

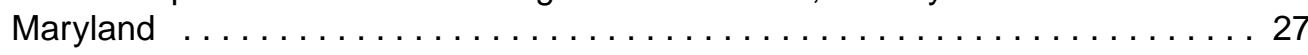

12. Summary of concentrations of major ions and radon-222 in ground water in the Big Elk Creek Basin, Pennsylvania and Maryland . ............... 30

13. U.S. Environmental Protection Agency maximum contaminant levels and secondary maximum contaminant levels for selected constituents in drinking water . . . . 31

14. Summary of concentrations of nutrients in ground water in the Big Elk Creek Basin, Pennsylvania and Maryland .............................. 34

15. Summary of concentrations of dissolved metals and trace constituents in ground water in the Big Elk Creek Basin, Pennsylvania and Maryland........... 35

16. Volatile organic compounds detected in ground water in the Big Elk Creek Basin,

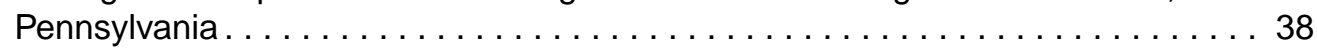

17. Pesticides detected in ground water in the Big Elk Creek Basin, Pennsylvania and Maryland ..................................... 39

18. Records of selected wells, Big Elk Creek Basin, Pennsylvania and Maryland . . . . 47

19. Water-level measurements, Big Elk Creek Basin, Pennsylvania and Maryland. . . . . 52

20. Results of field determinations and laboratory analyses for selected inorganic constituents in ground water, Big Elk Creek Basin, Pennsylvania and

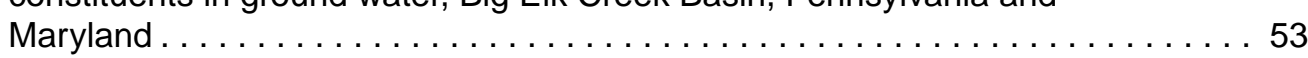

21. Results of laboratory analyses for pesticides in ground water, Big Elk Creek Basin,

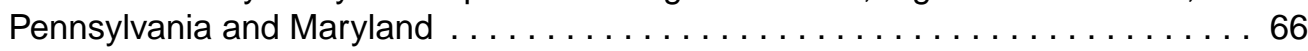




\section{CONVERSION FACTORS AND ABBREVIATIONS}

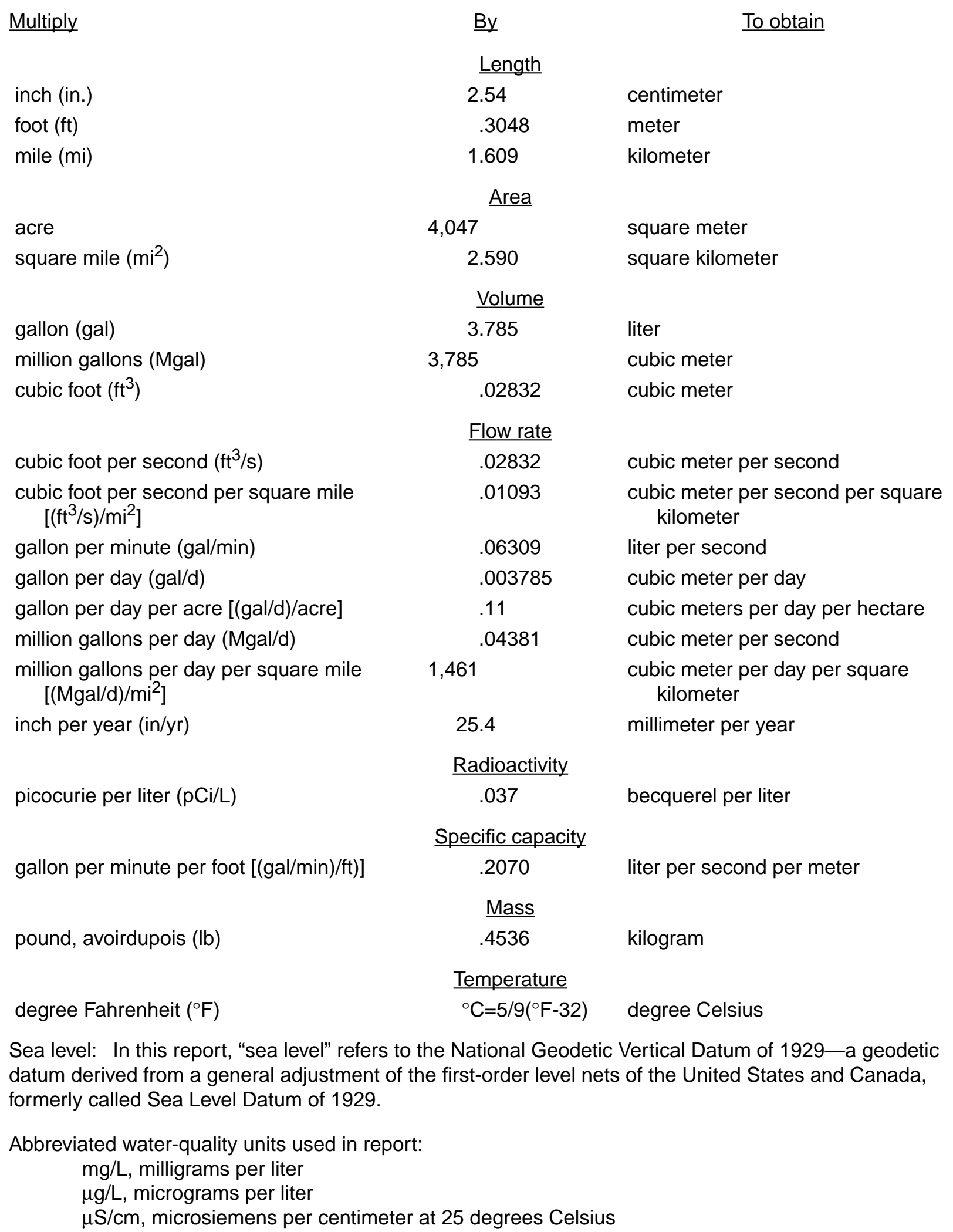




\title{
GEOHYDROLOGY AND GROUND-WATER QUALITY, BIG ELK CREEK BASIN, CHESTER COUNTY, PENNSYLVANIA AND CECIL COUNTY, MARYLAND
}

\author{
by Ronald A. Sloto
}

\begin{abstract}
A study of ground-water quantity and quality was conducted in the Big Elk Creek Basin, a rural area undergoing rapid growth. The 79.4-square mile study area is in the Piedmont Physiographic Province and is underlain almost entirely by crystalline rocks. Most of the basin in Pennsylvania is underlain by Wissahickon Schist, a fractured crystalline-rock aquifer. Yields of wells in the Wissahickon Schist range from 5 to $200 \mathrm{gal} / \mathrm{min}$ (gallons per minute); the median yield is $15 \mathrm{gal} / \mathrm{min}$. Specific capacity ranges from 0.03 to $15(\mathrm{gal} / \mathrm{min}) / \mathrm{ft}$ (gallons per minute per foot) of drawdown; the median specific capacity is $0.4(\mathrm{gal} / \mathrm{min}) / \mathrm{ft}$.
\end{abstract}

Recharge to the basin occurs by infiltration of precipitation, and ground water discharges locally to streams. The median annual ground-water discharge to streams (base flow) for 1933-99 was 10.79 in. (inches) or 0.518 (Mgal/d)/mi ${ }^{2}$ (million gallons per day per square mile), which was 63 percent of the median annual streamflow. The median annual ground-water discharge to streams ranged from $5.32 \mathrm{in}$. or $0.255(\mathrm{Mgal} / \mathrm{d}) / \mathrm{mi}^{2}$ in 1966 to $17.98 \mathrm{in}$. or $0.863(\mathrm{Mgal} / \mathrm{d}) / \mathrm{mi}^{2}$ in 1972 . Estimated ground-water availability ranges from 0.127 to $0.535(\mathrm{Mgal} / \mathrm{d}) / \mathrm{mi}^{2}$, depending on the estimation method used.

Annual water budgets were calculated for the Big Elk Creek Basin for 1998-99. The 1998-99 average annual streamflow was 15.38 in., change in ground-water storage was an increase of 1.32 in., ground-water exports were 0.03 in., and estimated evapotranspiration (ET) was 30.5 in. Despite a 12.27-in. difference in precipitation between 1998 and 1999, the percentage of precipitation as ET (65.6 and 64 percent, respectively) is similar. Estimated average annual recharge for 1998-99 was 12.12 in. [0.580 (Mgal/d)/mi²].

For this study, water samples from 20 wells in the Big Elk Creek Basin were collected for analysis for inorganic constituents and pesticides. In addition, data were available from 44 additional wells.
Major ions, in order of decreasing concentration, based on median concentrations for the Wissahickon Schist, are silica, calcium, chloride, sodium, sulfate, magnesium, and potassium. The Wissahickon Schist and Peters Creek Schist have similar water types; ground water from serpentinite, the basal unit of the Baltimore Mafic Complex that straddles the Pennsylvania-Maryland border, is distinctly different. For the Wissahickon Schist and Peters Creek Schist, no cation is predominant; calcium, magnesium, and sodium are in nearly equal concentrations expressed in milliequivalents per liter. Bicarbonate is the dominant anion. Water from serpentinite is of the magnesium bicarbonate type; magnesium is the dominant cation, and bicarbonate is the dominant anion.

Water from 2 percent of sampled wells exceeded the U.S. Environmental Protection Agency (USEPA) secondary maximum contaminant level (SMCL) for total dissolved solids. None of the chloride or sulfate concentrations exceeded the USEPA SMCL. Water from 10 percent of sampled wells exceeded the USEPA maximum contaminant level (MCL) of $10 \mathrm{mg} / \mathrm{L}$ (milligrams per liter) nitrate as nitrogen. All of those wells are in the Wissahickon Schist. The median concentration of nitrate in water samples from the Wissahickon Schist was $3.6 \mathrm{mg} / \mathrm{L}$, and the maximum concentration was $36 \mathrm{mg} / \mathrm{L}$. Except for iron and manganese, metals and other trace inorganic constituents do not appear to pose a water-quality problem. Fourteen percent of water samples analyzed for iron and 29 percent of water samples analyzed for manganese exceeded the USEPA SMCL's. The median activity of radon-222 for all formations was 2,400 pCi/L (picoCuries per liter). The median activity for water from 35 wells sampled in the Wissahickon Schist in the Big Elk Creek Basin was $2,500 \mathrm{pCi} / \mathrm{L}$. Water from 94 percent of sampled wells exceeded the proposed USEPA MCL of $300 \mathrm{pCi} / \mathrm{L}$, and water from 25 percent of sampled wells exceeded proposed USEPA alternate MCL of $4,000 \mathrm{pCi} / \mathrm{L}$. 
In addition to the 20 wells sampled for pesticides for this study, data were available for 20 other wells sampled for pesticides. The most commonly detected pesticides in the Big Elk Creek Basin are deethyl atrazine (71 percent of sampled wells), atrazine (35 percent of sampled wells), metolachlor (32 percent of sampled wells), carbaryl (19 percent of sampled wells), picloram (14 percent of sampled wells), simazine (13 percent of sampled wells), and carbofuran (11 percent of sampled wells). Most concentrations are extremely low and are in the parts per trillion range. Concentrations of pesticides detected did not exceed USEPA MCL's. Out of 43 volatile organic compounds analyzed, only 4 were detected-chloroform, total phenols, tertbutyl methyl ether (MTBE), and toluene. None of the concentrations exceeded USEPA MCL's.

\section{INTRODUCTION}

Many rural areas of southeastern Pennsylvania are undergoing a rapid population increase. New development and an expanding population increase consumptive water use, increase surface runoff, and have the potential to reduce groundwater recharge. The Big Elk Creek Basin in southeastern Pennsylvania and eastern Maryland is a rural basin that is begining to grow. Population in the Big Elk Creek Basin is projected to increase 20 percent between 1998 and 2020 with a corresponding projected increase in water demand of 162 Mgal per year (Chester County Water Resources Authority, 2001). In addition to increased demands for a reliable potable water supply, this projected growth also will require accommodating disposal of an increased volume of treated wastewater. An assessment of the ground-water resources, both quantity and quality, is necessary to guide this growth.

The Big Elk Creek Basin is between the Delaware and Susquehanna River Basins and drains directly to the Chesapeake Bay (fig. 1). The Delaware and Susquehanna River Basins have basin commissions that regulate and oversee surface- water and ground-water withdrawals. The Big Elk Creek Basin, located between these much larger basins, does not have a regulatory agency to oversee withdrawal of ground water.

In 1996, the Chester County Board of Commissioners adopted Landscapes, a comprehensive planning policy document, to guide growth management across the county (Chester County, 1996). By providing information about water quality and quantity in the Big Elk Creek Basin, the study described in this report supports the following goals of Landscapes: achieve and sustain a highquality natural resource system to protect public health and safety and support and protect a diversity of ecosystems (goal 2.1), protect a safe, longterm supply of water that is adequate for all uses (goal 2.1.1); protect and enhance the quality of ground water (goal 2.1.7); encourage a sustainable water-cycle balance within watersheds as development occurs (goal 2.1.9); and provide a safe, clean, long-term supply of water that meets the needs of all users (goal 6.1.6).

This study was done by the U.S. Geological Survey (USGS) in cooperation with the Chester County Water Resources Authority and the Chester County Health Department. The study provides county and township officials, planners, managers, and residents with the basic information necessary for management of the ground-water resource in the Big Elk Creek Basin.

This report presents and interprets groundwater quantity and quality data for the Big Elk Creek Basin in Chester County, Pa., and Cecil County, Md. The report focuses primarily on the Pennsylvania part of the basin. The report describes the geohydrology of aquifers in the basin and presents a summary of ground-water quality. Basin water budgets for the calendar years 1998 and 1999 are presented using streamflow data from the USGS streamflow-measurement station on Big Elk Creek and ground-water-level and precipitation data collected for this study. 


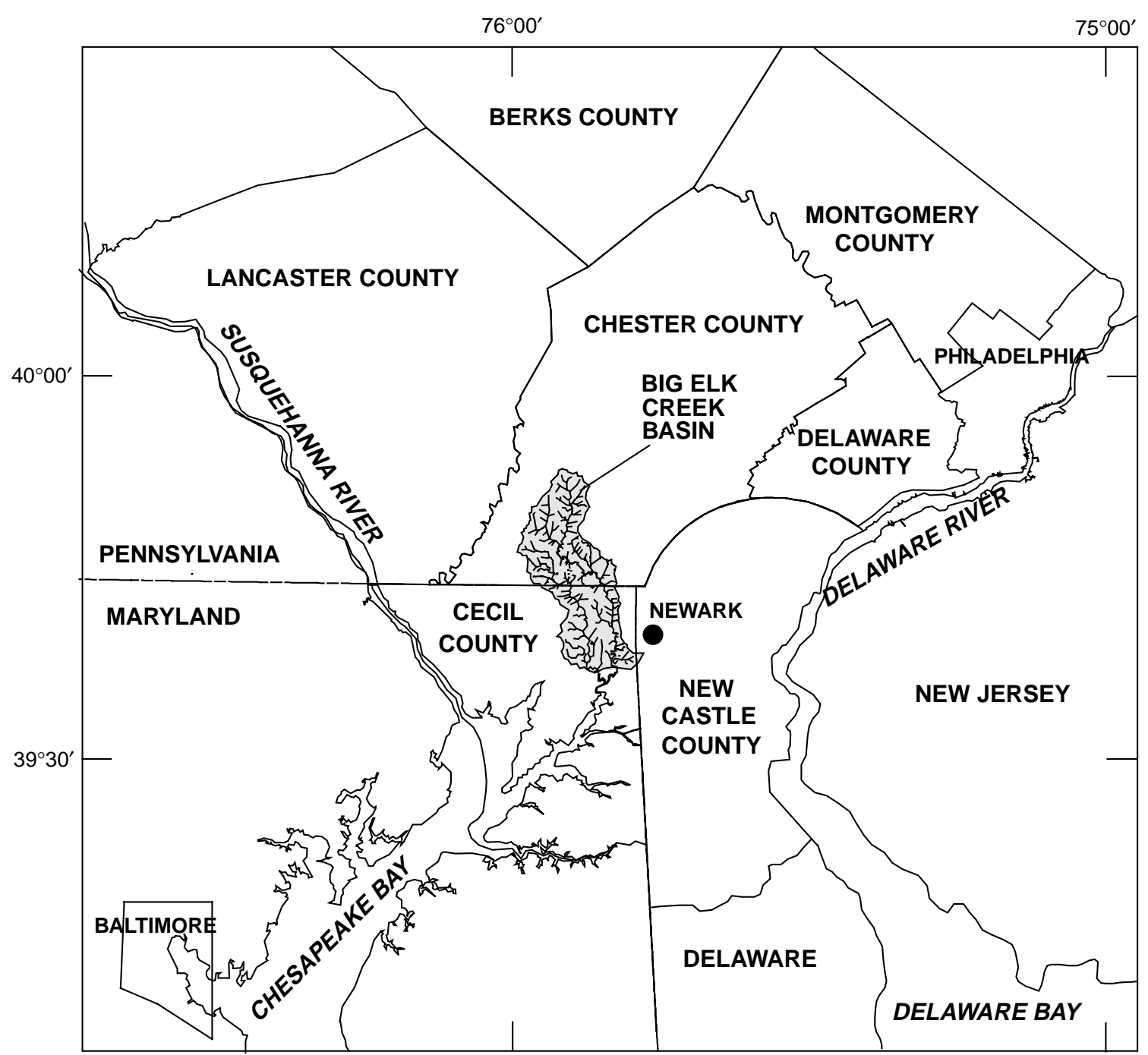

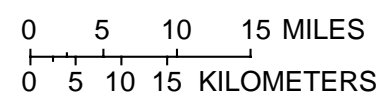

Figure 1. Location of the Big Elk Creek Basin, Pennsylvania and Maryland. 


\section{Location and Physiography}

The 79.4- $\mathrm{mi}^{2}$ study area extends from the headwaters in Chester County, Pa., downstream to the USGS streamflow-measurement station on Big Elk Creek at Elk Mills, Md., and an inactive USGS streamflow-measurement station on Little Elk Creek at Childs, Md. (fig. 2). The study area includes $52.6 \mathrm{mi}^{2}$ of the Big Elk Creek Basin and $26.8 \mathrm{mi}^{2}$ of the Little Elk Creek Basin. A small part of the Big Elk Creek Basin downstream of the study area lies in New Castle County, Del.

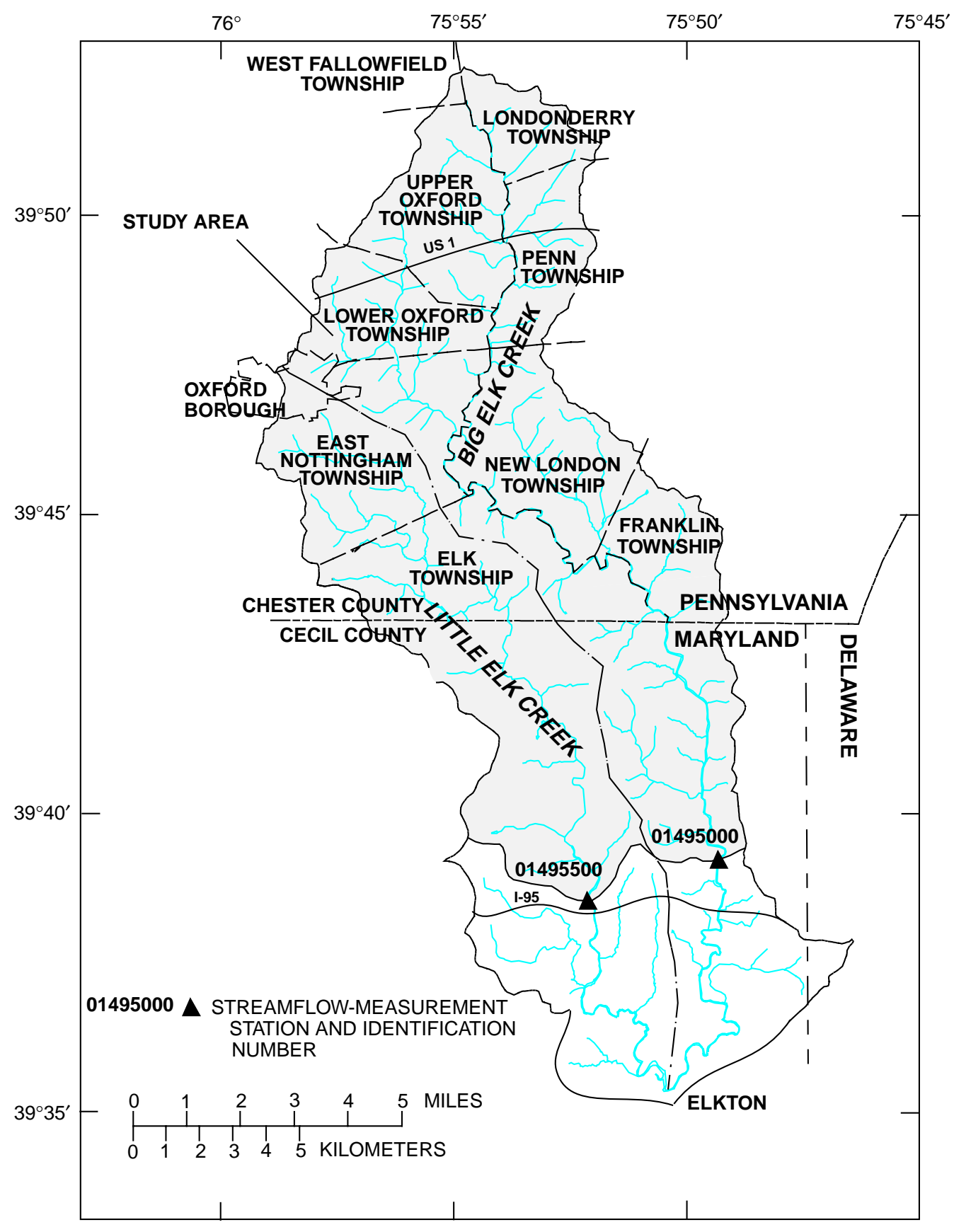

Figure 2. The Big Elk Creek Basin study area, Pennsylvania and Maryland. 
Little Elk Creek is a tributary to Big Elk Creek. Both streams flow south-southeast towards their confluence at Elkton, Md. A short distance south of Elkton, the Big Elk Creek becomes the Elk River and discharges to the Chesapeake Bay.

The Big Elk Creek Basin in the study area is in the Piedmont Physiographic Province and is underlain by crystalline rocks. The topography generally is rolling uplands, common to the Piedmont. The basin exhibits well-developed dendritic drainage patterns, and streams are moderately incised.

\section{Climate}

The climate in the Big Elk Creek Basin is a humid, modified continental climate characterized by warm summers and moderately cold winters. The nearby Atlantic Ocean exerts a considerable influence on the climate. The normal (1971-2000) mean annual temperature at the National Oceanic and Atmospheric Administration (NOAA) station at Newark, Del., approximately 3 mi east of the Big Elk Creek Basin, is $54.8^{\circ} \mathrm{F}\left(12.7^{\circ} \mathrm{C}\right)$ (National Oceanic and Atmospheric Administration, 2002). The normal (1971-2000) temperature for January, the coldest month, is $32.5^{\circ} \mathrm{F}\left(-0.3^{\circ} \mathrm{C}\right)$, and the normal temperature for July, the warmest month, is $76.4^{\circ} \mathrm{F}\left(24.7^{\circ} \mathrm{C}\right)$.

The normal annual (1971-2000) precipitation at the NOAA Newark, Del., station is 45.35 in. Precipitation is distributed fairly evenly throughout the year, although slightly more falls in May through August than in the other months. Much of the summer rainfall is supplied by thundershowers. Snowfalls seldom exceed a total of 5 to $10 \mathrm{in}$. Usually the snow cover disappears rapidly under the relatively mild winter temperatures.

\section{Well-Numbering System}

The well-numbering system in Pennsylvania is different from that in Maryland. In Pennsylvania, the well-identification number consists of a countyabbreviation prefix followed by a sequentially assigned local well number. The prefix $\mathrm{CH}$ denotes a well in Chester County. In Maryland, the wellnumbering system follows that of the Maryland Geological Survey and consists of two sets of two letters followed by a number. The first two letters of the well-identification number are the countyabbreviation prefix. The prefix CE denotes a well in Cecil County. The second two letters designate the 5 -minute quadrangle into which the county has been divided. The first letter denotes the 5-minute segment of latitude, and the second letter denotes the 5-minute segment of longitude. Wells are numbered sequentially within each 5-minute quadrangle.

\section{Previous Investigations}

In Pennsylvania, the geology was described by Bascom and Miller (1920) and Bascom and Stose (1932) and summarized by Sloto (1994). The geohydrology and ground-water quality of Chester County was described by Sloto (1994). Basic data for Chester County is given by Sloto (1989). Potentiometric-surface maps for the Big Elk Creek Basin are presented by Mohammad (2000; 2001).

In Maryland, the geology was described by Bascom and Miller (1920) and Higgins and Conant (1986; 1990). The ground-water resources are described by Overbeck and others (1958), Nutter and Otton (1969), and Otton and others (1988). Hydrologic data for Cecil County is presented by Willey and others (1987).

\section{Acknowledgments}

The cooperation of well owners who allowed access to their wells for sampling and water-level measurements is appreciated greatly. The author especially thanks the following observers who maintained and read precipitation gages for this study: Larry Fazio, Mary Gruber, William Laird, Robert Lester, Fred Muller, Rikki Saunders, Martha Straus, William Swoyer, and S.L. Walls.

Assistance and data also were provided by Cynthia Rossetti, the Elk Creeks Watershed Association, Fair Hill Natural Resources Management Area, Oxford Borough Water Department, Oxford Sewer Authority, and the Exelon Corporation. Kevin Grazul, formerly with the USGS, and Abdul Mohammad of the USGS collected data for this study. 


\section{GEOLOGY}

The Big Elk Creek Basin in the study area is underlain almost entirely by crystalline rocks of the Piedmont Physiographic Province (fig. 3). Most of these rocks have undergone more than one episode of deformation, and almost all exhibit compo- sitional alteration. The lowermost part of the study area and almost all of the Big Elk Creek Basin south of the study area is underlain by unconsolidated Coastal Plain sediments of the Potomac Group (fig. 3). The geologic units range in age from Lower Paleozoic to Cretaceous (table 1).

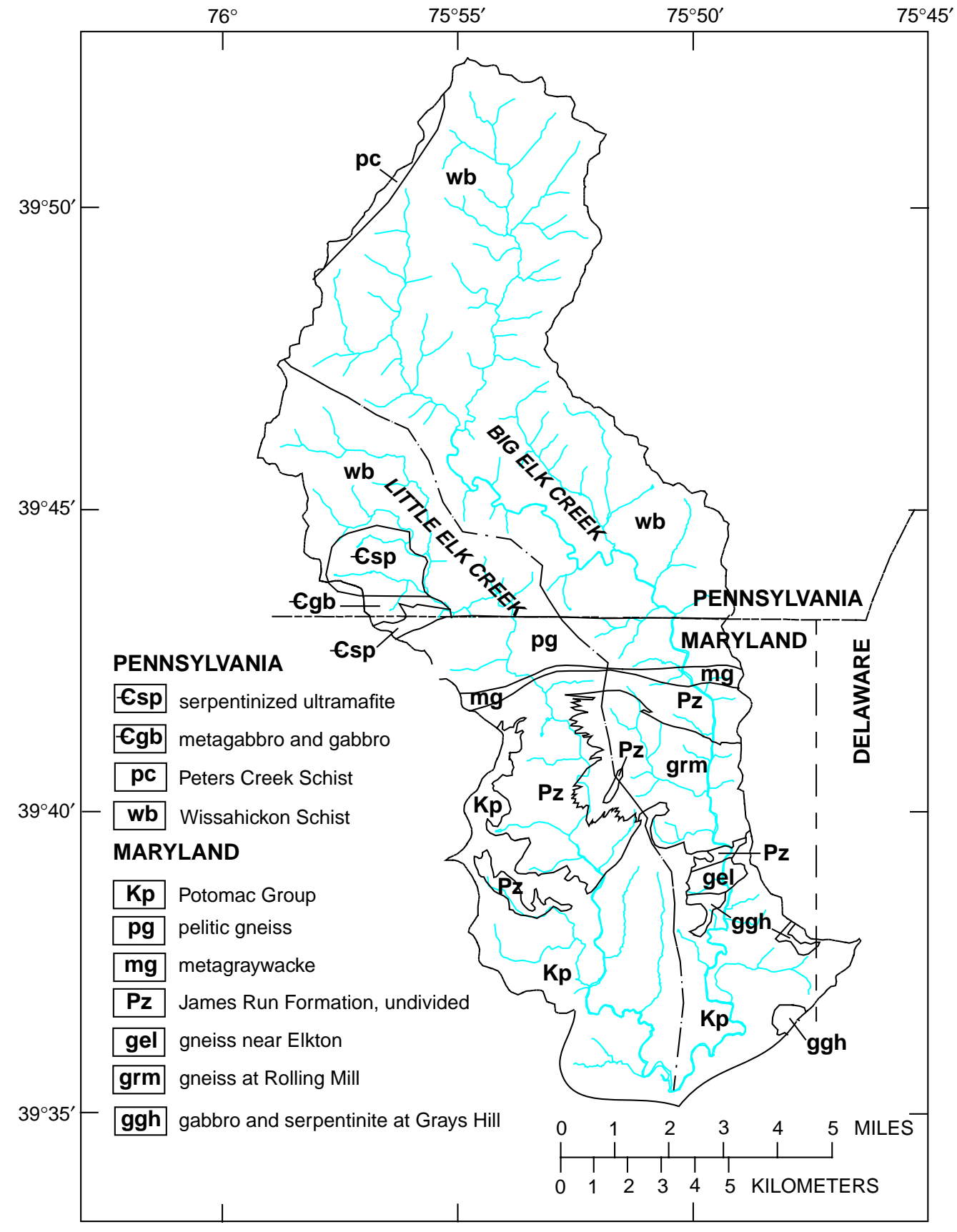

Figure 3. Generalized geologic map of the Big Elk Creek Basin, Pennsylvania and Maryland. 
Table 1. Geologic units in the Big Elk Creek Basin, Pennsylvania and Maryland

[Compiled from Sloto (1994) and Higgins and Conant (1986)]

\begin{tabular}{|c|c|c|}
\hline \multicolumn{2}{|c|}{ Geologic unit and map symbol } & \multirow{2}{*}{ Age } \\
\hline Pennsylvania & Maryland & \\
\hline \multirow{3}{*}{ Peters Creek Schist (pc) } & Potomac Group (Kp) & Upper and Lower Cretaceous \\
\hline & & Late Precambrian to Middle Ordovician \\
\hline & James Run Formation (Pz) & Lower Paleozoic \\
\hline \multirow{4}{*}{$\begin{array}{l}\text { gabbro and metagabbro (Cgb) } \\
\text { serpentinized ultramafite (Csp) }\end{array}$} & $\begin{array}{l}\text { gneiss near Elkton (gel) and gneiss at Rolling } \\
\text { Mill (grm) }\end{array}$ & Lower Paleozoic to Upper Precambrian \\
\hline & gabbro (Cgb) & Lower Paleozoic to Upper Precambrian \\
\hline & serpentinite (Csp) & Lower Paleozoic to Upper Precambrian \\
\hline & gabbro and serpentinite at Grays Hill (ggh) & Lower Paleozoic to Upper Precambrian \\
\hline & pelitic gneiss (pg) & Lower Paleozoic \\
\hline Wissahickon Schist (wb) & metagraywacke $(\mathrm{mg})$ & Lower Paleozoic \\
\hline
\end{tabular}

Most of the Big Elk Creek Basin in Pennsylvania is underlain by Wissahickon Schist. The Wissahickon Schist consists of metasediments metamorphosed to amphibolite grade. The Wissahickon is a light to medium gray, fine- to medium-grained, quartzo-aluminous schist and gneiss. Composition ranges from quartz-orthoclase-biotite and orthoclase-quartz-muscovite schist to quartz-biotite-plagioclase and quartz-plagioclase-biotite schistose gneiss. Garnet and/or sillimanite are abundant locally. Foliation generally is very well developed. In places, the Wissahickon is cut by diabase and pegmatite dikes. Bascom and Stose (1932) estimated the Wissahickon Schist and Octoraro Phyllite (formerly considered part of the Wissahickon Schist) to be 5,000 to $8,000 \mathrm{ft}$ thick.

In Maryland, the name Wissahickon Schist is no longer used. The rocks formerly assigned to the Wissahickon Schist have been subdivided into an informally named pelitic, diamictite, and metagraywacke metasedimentary lithofacies by Higgins and Conant (1990). Pelitic gneiss and metagraywacke are present in the Big Elk Creek Basin.

The metagraywacke is an interbedded, tan to grayish green, chlorite-biotite-plagioclase-muscovite-quartz gneiss or silvery-gray to grayish-green, plagioclase-quartz-biotite-muscovite schist (Higgins and Conant, 1986). It consists of pelitic schists, metasiltstones, and metagraywacke collectively referred to as metagraywacke by Higgins and Conant (1990, p. 19-20). The metagraywacke sequences commonly consist of graded metagraywacke and metasiltsone beds that range in thickness from 1 to $8 \mathrm{ft}$ and are interbedded with sections of approximately the same thickness of finely laminated pelitic schist. The layers are less than $1 / 16$ in. thick and occur in sections up to $40 \mathrm{ft}$ thick.

The pelitic gneiss is a lustrous, brown, medium- to coarse-grained, layered, strongly schistose rock riddled with quartzofeldspathic and aplitic segregations and cut by numerous pegmatite veins and veinlets. It generally is a muscovitebiotite-quartz-plagioclase gneiss with abundant garnets. It weathers to a red-brown clayey saprolite containing abundant vein quartz fragments and fairly abundant quartz grains. The contacts of the pelitic gneiss appear to be gradational with other units of the metasedimentary rock sequence (Higgins and Conant, 1990, p. 9).

The allochthonous Baltimore Mafic Complex straddles the Pennsylvania-Maryland border in the western part of the Big Elk Creek Basin. The Baltimore Mafic Complex consists of a basal unit of interlayered metamorphosed peridotite-gabbro overlain by gabbro containing upper level peridotite (Hanan and Sinha, 1989). The complex may have formed in a marginal basin originating inland from a continental margin volcanic arc or as a sub-arc plutonic complex. The basal unit is mapped as serpentinized ultramafite in Pennsylvania and serpentinite in Maryland. It is called serpentinite in this report. The serpentinite is a lustrous, highly sheared and fractured, bluish-green, talcose serpentinite or "soapstone," with no visible evidence of original texture or other features (Higgins and Conant, 1990, p. 39-41). It contains minor amounts of unserpentized ultramafic rocks and some mafic rocks. The most distinguishing feature is that it 
commonly contains significant amounts of chromite, as disseminated elongated grains and as massive pediform ore bodies.

The metagabbro and gabbro unit in Pennsylvania is called gabbro in Maryland. It is called gabbro in this report. The gabbro generally is massive hypersthene gabbro in various stages of alteration to uralite gabbro but includes minor amounts of a wide variety of mafic and, locally, ultramafic rocks (Higgins and Conant, 1990, p. 41-42). The gabbro is in thrust fault contact with the Wissahickon Schist. Hanan and Sinha (1989) estimate that the Baltimore Mafic Complex is less than $6,500 \mathrm{ft}$ thick.

Gabbroic rocks and lesser amounts of serpentinite are present in the valley of Big Elk Creek and its tributaries north of Elkton. These rocks are mapped as "gabbro and serpentinite at Grays Hill" and consist of black to very dark green, coarse- to very coarse-grained, uralized hypersthene gabbro and serpentinite. The rocks are poorly exposed and deeply weathered (Higgins and Conant, 1990, p. 42-43).

A medium-grained, plutonic-appearing rock mapped as "gneiss near Elkton" extends about $1 \mathrm{mi}$ west of Big Elk Creek. It is a well foliated, gray-tan, medium- to coarse-grained biotite-quartzplagioclase, homogeneous, well-foliated, biotite granodiorite gneiss with granoblastic texture (Higgins and Conant, 1990, p. 49). A medium gray, fine- to medium-grained biotite-plagioclase gneiss, commonly containing tiny garnets and magnetite crystals, underlies a large area between Little Elk Creek and the Delaware State line. This gneiss is mapped as "gneiss at Rolling Mill." The "gneiss at Rolling Mill" is similar petrographically to the "gneiss near Elkton" and may be correlative because the two are separated by only a thin belt of metavolcanic rocks (Higgins and Conant, 1990, p. 49).

The James Run Formation, which is undivided on figure 3 , is an interlayered quartz amphibolite and biotite-quartz-plagioclase gneiss of probable volcanic and volcaniclastic origin. The James Run Formation is divided into seven formally named members described by Higgins and Conant (1990, p. 21-37).
A small area in the northwestern corner of the Big Elk Creek Basin is underlain by the Peters Creek Schist. The Peters Creek Schist consists of a flyschoid sequence of metagraywacke and pelite rich in quartz and magnetite (Lyttle and Epstein, 1987). The Peters Creek Schist generally is a green, fine-grained, finely laminated, mica schist with numerous thin to thick interbeds of chloritebearing granular quartzite. The pelitic part usually is a quartz-muscovite-chlorite-orthoclase schist. Bascom and Stose (1932) estimate that the Peters Creek Schist is about 2,000 ft thick.

The Cretaceous-age deposits of the Potomac Group underlie the southern part of the Big Elk Creek Basin. The Potomac Group is made up of an irregular succession of lenses and layers of a thick sequence of non-marine quartzose sands, silts, clays, and gravelly sands, as well as various intermediate mixtures of these that accumulated in a fluviatile environment (Higgins and Conant, 1990, p. 124-132). The maximum thickness is about $1,300 \mathrm{ft}$.

\section{HYDROLOGY}

All of the crystalline-rock units in the Big Elk Creek Basin are considered to be aquifers. The terms geologic unit and aquifer are used interchangeably in this report. These rocks sometimes are referred to as "bedrock aquifers." Nearly all wells have casing set into the upper few feet of unweathered rock and are completed as open-hole wells. The hydrology of the unconsolidated Potomac Group is not discussed in this report but can be found in Overbeck and others (1958).

\section{Ground Water}

In crystalline rocks, ground water moves through intergranular openings in the weathered zone (saprolite) and through a network of interconnecting secondary openings_-fractures and joints -in the underlying unweathered bedrock (fig. 4). The permeability of fractured crystalline rock depends on the number of fractures, the size of the fracture openings, and the degree of interconnection of the fractures. A considerable quantity of water may be stored in the weathered zone (saprolite) where it is thick. 


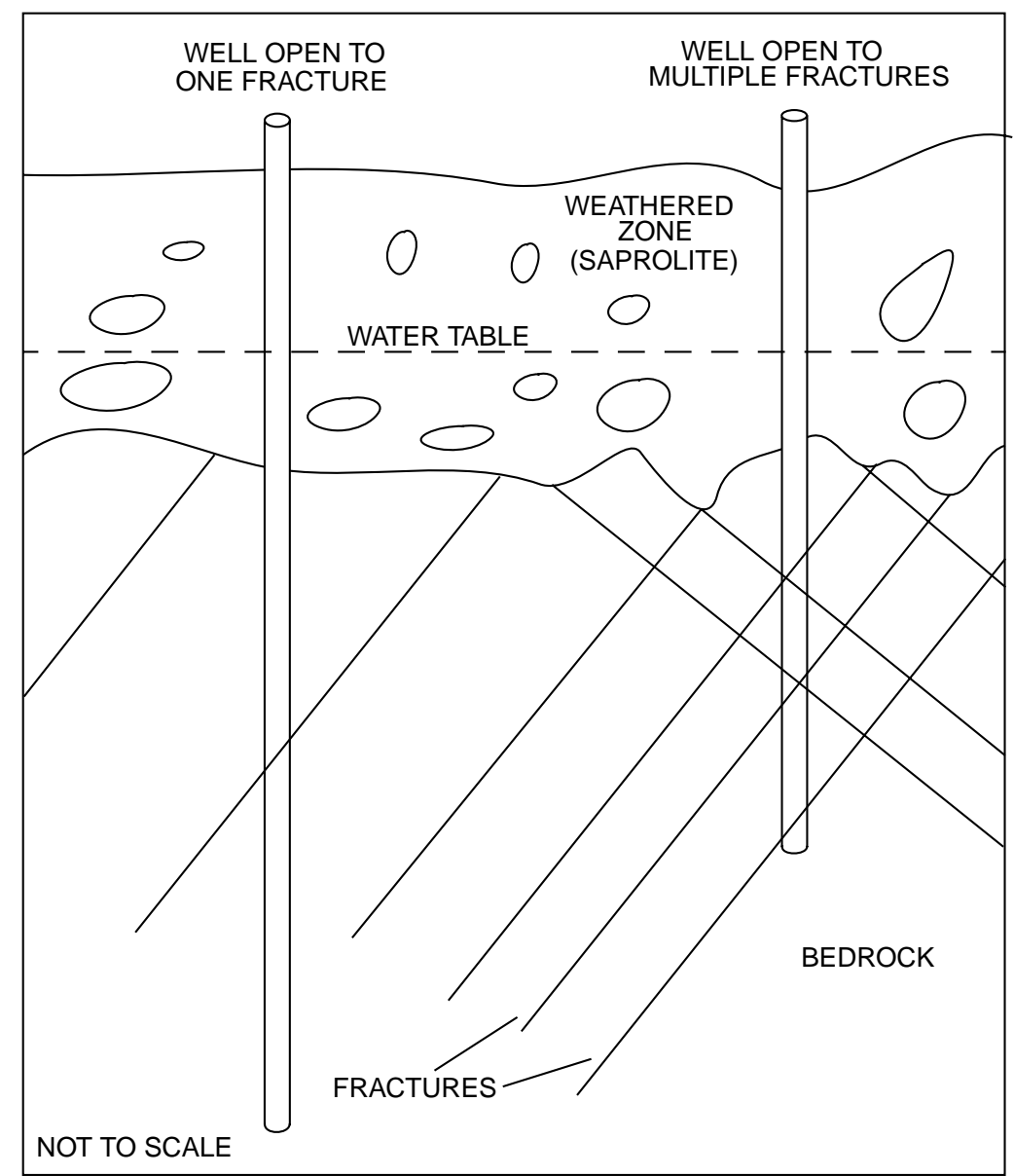

Figure 4. Diagram showing wells in fractured rock.

The ground-water-flow systems in crystalline rock are of local extent with streams acting as drains. Flow paths are short, and ground water flows from areas of higher elevation to adjacent streams. Ground-water and surface-water divides usually coincide. The hydrologic system generally is unconfined (water-table conditions), and the water table is a subdued replica of the land surface. In areas where fractures are far apart and poorly interconnected, a true water table may be absent, and each system of fractures may have its own water level. Locally, ground water may be semiconfined. A few wells flow; these wells penetrate water-bearing zones with hydraulic heads greater than the land-surface altitude.

\section{Well and Aquifer Characteristics}

Some of the aquifer characteristics used to describe ground-water flow and assess the productivity of an aquifer are the number of water-bearing zones, well yield, and specific capacity. These aquifer characteristics are discussed briefly in the following sections.

\section{Water-Bearing Zones}

Primary (intergranular) porosity below the weathered zone is nonexistent in the crystalline rocks of the Big Elk Creek Basin. Ground water flows through a network of interconnected secondary openings that comprise the water-bearing zones that provide water to wells. The number and size of the water-bearing openings determines the secondary porosity of the rock; the number, size, and degree of interconnection of the openings 
determines the secondary permeability. The larger, more numerous, and more interconnected the openings, the greater the yield of a well drilled into that rock. Where a formation is extensively fractured, permeability may be high; elsewhere, where few fractures are present, the same unit may be nearly impermeable.

The distribution of reported water-bearing zones was analyzed for wells completed in the Wissahickon Schist in the Big Elk Creek Basin, and, for comparison, in Chester County. Available data for wells completed in the Peters Creek Schist and serpentinite in the Big Elk Creek Basin were insufficient for statistical analysis. Therefore, data were analyzed for all wells in Chester County for those geologic units. Available data for wells completed in gabbro were insufficient for statistical analysis.
The frequency of water-bearing zones in the Wissahickon Schist was analyzed for 87 wells with 173 water-bearing zones in $4,865 \mathrm{ft}$ of uncased borehole and well depths to $400 \mathrm{ft}$ for the Big Elk Creek Basin and for 407 wells with 800 water-bearing zones in 46,369 ft of uncased borehole and well depths to $1,000 \mathrm{ft}$ for wells in Chester County (table 2). The frequency of water-bearing zones is expressed in units of water-bearing zones per $100 \mathrm{ft}$ of uncased borehole. Wells in the Wissahickon Schist in the Big Elk Creek Basin had a higher mean (3.56) of water-bearing zones per $100 \mathrm{ft}$ of uncased borehole than did wells in the Wissahickon Schist in Chester County (mean of 1.73). The mean number of water-bearing zones per $100 \mathrm{ft}$ of uncased borehole was similar (1.531.93) for wells in the Wissahickon Schist, Peters Creek Schist, and serpentinite in Chester County. For all geologic units, the frequency of occurrence of water-bearing zones generally decreases with depth (table 2).

Table 2. Number of water-bearing zones reported per 100 feet of uncased borehole drilled in the Big Elk Creek Basin, Chester County, Pennsylvania

[--, no data]

\begin{tabular}{|c|c|c|c|c|c|c|}
\hline \multirow{2}{*}{$\begin{array}{c}\text { Interval } \\
\text { (feet below land } \\
\text { surface) }\end{array}$} & \multicolumn{2}{|c|}{ Number of water-bearing zones } & \multirow{2}{*}{$\begin{array}{l}\text { Footage drilled } \\
\text { (feet) }\end{array}$} & \multicolumn{2}{|c|}{$\begin{array}{c}\text { Number of water-bearing } \\
\text { zones }\end{array}$} & \multirow{2}{*}{$\begin{array}{l}\text { Footage drilled } \\
\text { (feet) }\end{array}$} \\
\hline & Total & $\begin{array}{l}\text { Per } 100 \text { feet } \\
\text { of borehole }\end{array}$ & & Total & $\begin{array}{l}\text { Per } 100 \text { feet of } \\
\text { borehole }\end{array}$ & \\
\hline & \multicolumn{3}{|c|}{ Wissahickon Schist, Big Elk Creek Basin (87 wells) } & \multicolumn{3}{|c|}{ Wissahickon Schist, Chester County (407 wells } \\
\hline $0-50$ & 11 & 3.34 & 330 & 85 & 3.09 & 2,752 \\
\hline $51-100$ & 85 & 4.16 & 2,041 & 318 & 2.35 & 13,533 \\
\hline $101-150$ & 59 & 3.36 & 1,756 & 183 & 1.57 & 11,688 \\
\hline $151-200$ & 14 & 2.91 & 481 & 96 & 1.40 & 6,833 \\
\hline $201-250$ & 2 & 1.87 & 107 & 49 & 1.13 & 4,321 \\
\hline $251-300$ & 0 & 0 & 50 & 35 & 1.19 & 2,938 \\
\hline $301-350$ & 1 & 2 & 50 & 13 & .86 & 1,518 \\
\hline $351-400$ & 1 & 2 & 50 & 12 & 1.18 & 1,017 \\
\hline $401-450$ & -- & -- & -- & 4 & .73 & 546 \\
\hline $451-500$ & -- & -- & -- & 5 & 1.11 & 452 \\
\hline $501-1,000$ & -- & -- & -- & 0 & 0 & 771 \\
\hline \multirow[t]{2}{*}{ Total (mean) } & 173 & $(3.56)$ & 4,865 & 800 & $(1.73)$ & 46,369 \\
\hline & \multicolumn{3}{|c|}{ Peters Creek Schist, Chester County ( 77 wells) } & \multicolumn{3}{|c|}{ Serpentinite, Chester County ( 27 wells) } \\
\hline $0-50$ & 21 & 2.64 & 796 & 11 & 3.16 & 348 \\
\hline $51-100$ & 78 & 2.68 & 2,728 & 17 & 1.77 & 961 \\
\hline $101-150$ & 32 & 1.71 & 1,869 & 7 & 1.31 & 533 \\
\hline $151-200$ & 8 & .78 & 1,027 & 2 & .62 & 325 \\
\hline $201-250$ & 10 & 1.58 & 633 & 1 & .53 & 190 \\
\hline $251-300$ & 1 & .26 & 387 & 0 & 0 & 140 \\
\hline $301-350$ & 0 & 0 & 205 & 1 & 1.92 & 52 \\
\hline $351-400$ & 1 & 1 & 100 & -- & -- & -- \\
\hline $401-500$ & 0 & 0 & 77 & -- & -- & -- \\
\hline Total (mean) & 151 & (1.93) & 7,822 & 39 & (1.53) & 2,549 \\
\hline
\end{tabular}




\section{Well Yield}

Reported well yield is the discharge of a well measured during pumping, usually near the time of well completion, and does not represent a longterm yield for the well. Well construction, well-bore storage, pumping rate, and pumping duration can affect the well yield. Reported yields for wells in the Big Elk Creek Basin are summarized in table 3. Because few data are available for geologic units other than the Wissahickon Schist in the Big Elk Creek Basin, data for all wells in Chester and Cecil Counties for the geologic units present in the basin are given in table 3. Yields of wells in the Wissahickon Schist in the Big Elk Creek Basin range from 5 to $200 \mathrm{gal} / \mathrm{min}$ with a median yield of $15 \mathrm{gal} / \mathrm{min}$. The median yield was similar (10$15 \mathrm{gal} / \mathrm{min}$ ) for wells in all geologic units in Chester and Cecil Counties.

\section{Specific Capacity}

Specific capacity is a more meaningful measure of aquifer productivity than well yield because it can be related directly to aquifer transmissivity. Specific capacity is calculated by dividing the pumping rate of a well by the drawdown and reflects combined efficiency of the well and aquifer transmissivity. Specific capacity for a well pumped at a constant yield decreases with time.

Because few specific-capacity data are available for geologic units other than the Wissahickon Schist in the Big Elk Creek Basin, data for all wells in Chester and Cecil Counties for the geologic units present in the basin are given in table 4. Specificcapacity data are determined from aquifer tests performed by drillers, water purveyors, and consultants. The median specific capacities (0.20.4 (gal $/ \mathrm{min}) / \mathrm{ft}$ of drawdown) of all the geologic units are similar (table 4).

Table 3. Minimum, maximum, and median reported well yields for wells in the Big Elk Creek Basin, Chester County, Pennsylvania, and Cecil County, Maryland

[gal/min, gallons per minute; --, insufficient data to compute median]

\begin{tabular}{|c|c|c|c|c|}
\hline \multirow{2}{*}{ Geologic unit } & \multirow{2}{*}{$\begin{array}{l}\text { Number } \\
\text { of wells }\end{array}$} & \multicolumn{3}{|c|}{$\begin{array}{l}\text { Well yield } \\
\text { (gal/min) }\end{array}$} \\
\hline & & Minimum & Median & Maximum \\
\hline \multicolumn{5}{|l|}{ Big Elk Creek Basin } \\
\hline Peters Creek Schist & 4 & 10 & -- & 45 \\
\hline Gabbro & 3 & 15 & -- & 75 \\
\hline Serpentinite & 6 & 4 & -- & 45 \\
\hline Wissahickon Schist & 125 & 5 & 15 & 200 \\
\hline \multicolumn{5}{|l|}{ Chester County } \\
\hline Peters Creek Schist & 207 & .2 & 10 & 312 \\
\hline Gabbro & 5 & 15 & -- & 75 \\
\hline Serpentinite & 46 & 2 & 12 & 80 \\
\hline Wissahickon Schist & 808 & 0 & 15 & 412 \\
\hline \multicolumn{5}{|l|}{ Cecil County ${ }^{1}$} \\
\hline Gabbro & 35 & 3 & 10 & 100 \\
\hline Serpentinite & 23 & 2 & 10 & 200 \\
\hline Pelitic gneiss & 12 & 3 & 10 & 200 \\
\hline Metagraywacke & 20 & 1 & 10 & 100 \\
\hline
\end{tabular}

${ }^{1}$ From Otton and others (1988, p. 19). 
Table 4. Minimum, maximum, and median reported specific capacity for wells in the Big Elk Creek Basin, Chester County, Pennsylvania, and Cecil County, Maryland

[(gal/min)/ft, gallons per minute per foot of drawdown; --, insufficient data to compute median; <, less than]

\begin{tabular}{lcccc}
\hline \multicolumn{1}{c}{ Geologic unit } & $\begin{array}{c}\text { Number of } \\
\text { wells }\end{array}$ & \multicolumn{3}{c}{$\begin{array}{c}\text { Specific capacity } \\
\text { [(gal/min)/ft] }\end{array}$} \\
\cline { 3 - 5 } & & Minimum & Median & Maximum \\
\hline Big Elk Creek Basin & 5 & 0.16 & -- & 0.8 \\
Peters Creek Schist & 3 & .11 & -- & 3.4 \\
Gabbro & 6 & .04 & -- & 15 \\
Serpentinite & 84 & .03 & 0.4 & 15 \\
Wissahickon Schist & & & & \\
Chester County & 42 & $<.01$ & .4 & 11.3 \\
Peters Creek Schist & 21 & .1 & -- & 4.17 \\
Gabbro & 325 & $<.01$ & .2 & 15 \\
Serpentinite & & & .3 & 100 \\
Wissahickon Schist & 27 & $<.1$ & .01 & 17 \\
Cecil County & 19 & $<.1$ & .3 & 20 \\
Gabbro & 9 & $<.1$ & .2 & 2 \\
Serpentinite & 16 & $<.1$ & .4 & 5 \\
Pelitic gneiss & & & & \\
Metagraywacke & & & & \\
\hline
\end{tabular}

${ }^{1}$ From Otton and others (1988, p. 19).

\section{Water Levels}

Water levels measured in wells in an unconfined aquifer indicate the level of the water table. Water levels commonly are measured and reported as the depth to water below land surface. Static water levels in an aquifer that is not being pumped or stressed by other anthropogenic activities reflect natural conditions.

Approximately 800 wells were measured on a one-time only basis to construct two potentiometric-surface (water-table) maps of the Big Elk Creek Basin in Pennsylvania. The upper part of the basin was mapped by Mohammad (2000) in 1999, and the lower part was mapped by Mohammad (2001) in 2000 . On the maps, the potentiometric surface is the water table represented by measured water levels in wells. The water table is a subdued replica of the land surface. The maps show that groundwater flow paths are short, and ground-water flow is from areas of higher elevation to adjacent streams. The streams act as drains for the groundwater system.

\section{Depth to water}

Under natural conditions in an unconfined aquifer, water levels generally are closest to land surface in valleys near streams (discharge areas) and deepest below land surface on hilltops (recharge areas). Water-level data categorized by topographic position for wells in the Wissahickon Schist in the Big Elk Creek Basin show that the median depth to water is $19 \mathrm{ft}$ for wells in valleys, $25 \mathrm{ft}$ for wells on hillsides, and $30 \mathrm{ft}$ for wells on hilltops (table 5). In the Big Elk Creek Basin, the median depth to water ranged from $13 \mathrm{ft}$ for wells in serpentinite to $28 \mathrm{ft}$ for wells in Peters Creek Schist.

\section{Fluctuations}

Water levels fluctuate in response to recharge to the ground-water system from precipitation and discharge from the ground-water system to pumping wells, to the atmosphere by ground-water evapotranspiration, and to streams. Water levels in the Big Elk Creek Basin generally rise during the late fall, winter, and early spring when groundwater and soil-moisture evapotranspiration are at a minimum and recharge is at a maximum. Water 
Table 5. Minimum, maximum, and median reported depth to water in wells in the Big Elk Creek Basin, Chester County, Pennsylvania, and Cecil County, Maryland

[A negative number indicates water level above land surface; --, insufficient data to compute median]

\begin{tabular}{|c|c|c|c|c|}
\hline \multirow{2}{*}{ Geologic unit } & \multirow{2}{*}{$\begin{array}{l}\text { Number of } \\
\text { wells }\end{array}$} & \multicolumn{3}{|c|}{$\begin{array}{c}\text { Depth to water } \\
\text { (feet below land surface) }\end{array}$} \\
\hline & & Minimum & Median & Maximum \\
\hline \multicolumn{5}{|l|}{ Big Elk Creek Basin } \\
\hline Peters Creek Schist & 12 & 15 & 28 & 44 \\
\hline Gabbro & 3 & 14 & -- & 24 \\
\hline Serpentinite & 6 & 5 & 13 & 20 \\
\hline Wissahickon Schist, all wells & 209 & 0 & 25 & 73 \\
\hline Wissahickon Schist, hilltop wells & 44 & 15 & 30 & 59 \\
\hline Wissahickon Schist, hillside wells & 155 & 0 & 25 & 73 \\
\hline Wissahickon Schist, valley wells & 5 & 7 & 19 & 20 \\
\hline \multicolumn{5}{|l|}{ Chester County } \\
\hline Peters Creek Schist & 198 & 2 & 32 & 144 \\
\hline Gabbro & 4 & 8 & -- & 24 \\
\hline Serpentinite & 37 & 5 & 20 & 70 \\
\hline Wissahickon Schist & 907 & -3 & 26 & 115 \\
\hline \multicolumn{5}{|l|}{ Cecil County ${ }^{1}$} \\
\hline Gabbro & 48 & 3 & 20 & 50 \\
\hline Serpentinite & 27 & 3 & 17 & 50 \\
\hline Pelitic gneiss & 19 & 4 & 15 & 43 \\
\hline Metagraywacke & 31 & 6 & 20 & 64 \\
\hline
\end{tabular}

${ }^{1}$ From Otton and others (1988, p. 17).

levels generally decline during the late spring, summer, and early fall when ground-water evapotranspiration and soil-moisture evapotranspiration are at a maximum and recharge is at a minimum.

Water levels were measured monthly in eight wells from January 1998 through December 1999 (fig. 5). Additionally, three wells were instrumented with digital water-level recording loggers (fig. 5). Water levels in observation wells in different geologic units in the Big Elk Creek Basin show similar patterns of response to seasonal changes in recharge and evapotranspiration (fig. 6). Water levels generally decline in the summer and fall despite precipitation because recharge is offset by evapotranspiration. The range in fluctuation in these wells for 1998-99 was up to $12.55 \mathrm{ft}$.

Although the seasonal fluctuations in water levels are similar from year to year, changes in climatic conditions affect the seasonal pattern (fig. 7). For example, 1991 and 1992 were drier than normal years, and little recharge occurred during the cold months. 1996 was a wetter than normal year, and recharge occurred during the entire year. 


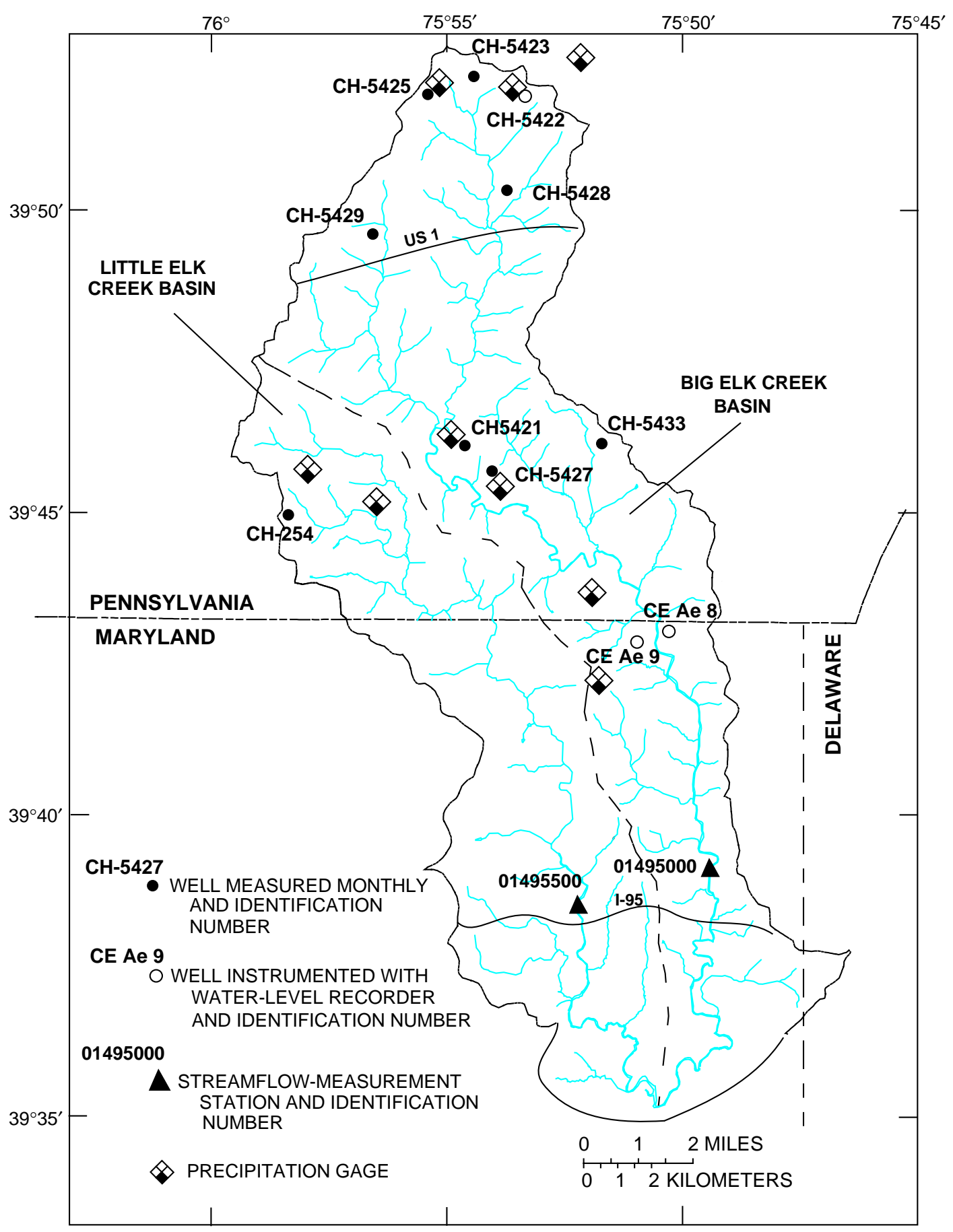

Figure 5. Location of streamflow-measurement stations, observation wells, and precipitation gages in the Big Elk Creek Basin, Pennsylvania and Maryland. 


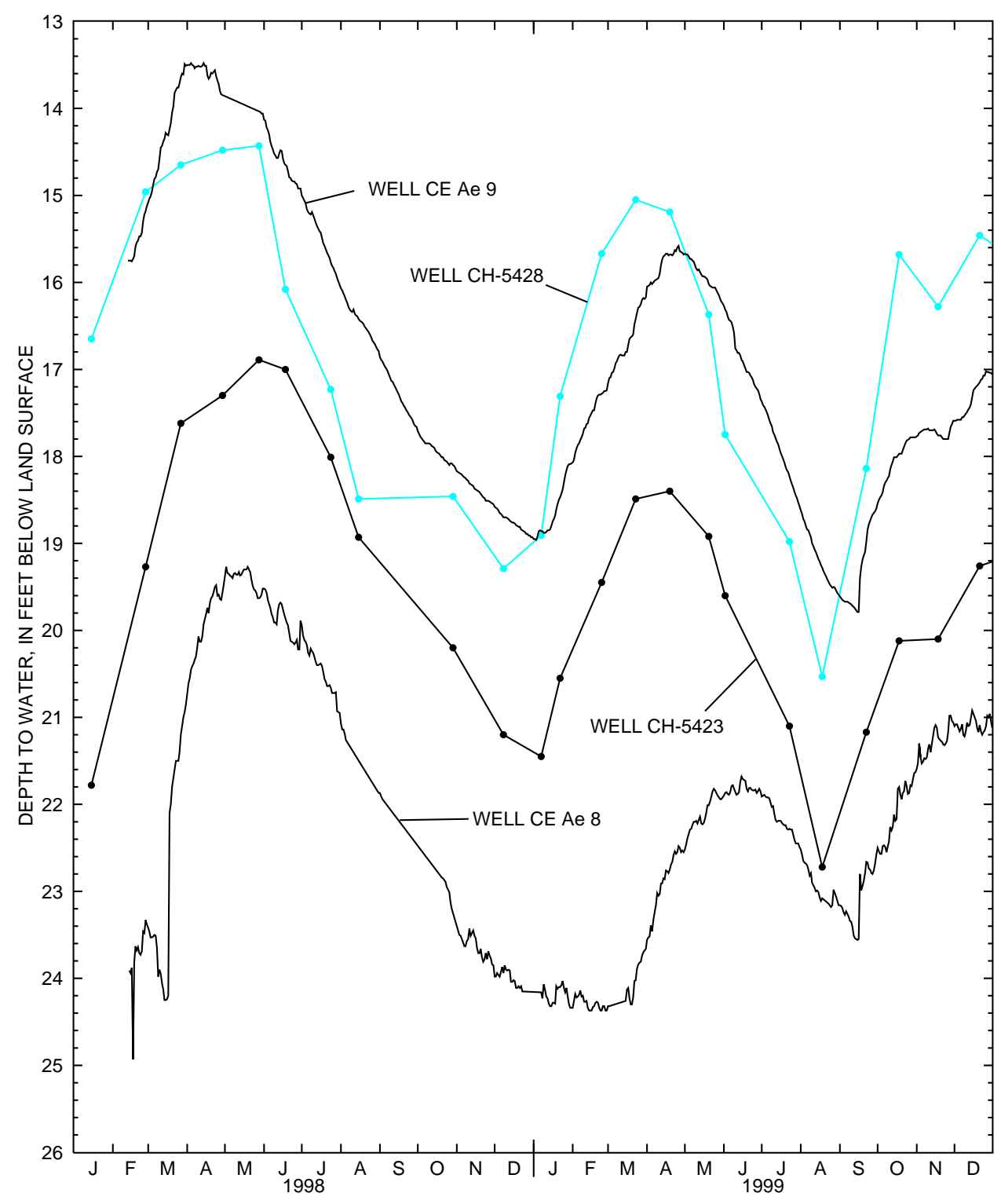

Figure 6. Depth to water in wells $\mathrm{CH}-5423, \mathrm{CH}-5428, \mathrm{CE}$ Ae 8, and $\mathrm{CE}$ Ae 9, 1998-99, Big Elk Creek Basin, Pennsylvania and Maryland. Wells $\mathrm{CH}-5423$ and $\mathrm{CH}-5428$ were measured monthly. Wells CE Ae 8 and CE Ae 9 were equipped with continuous water-level recorders. 


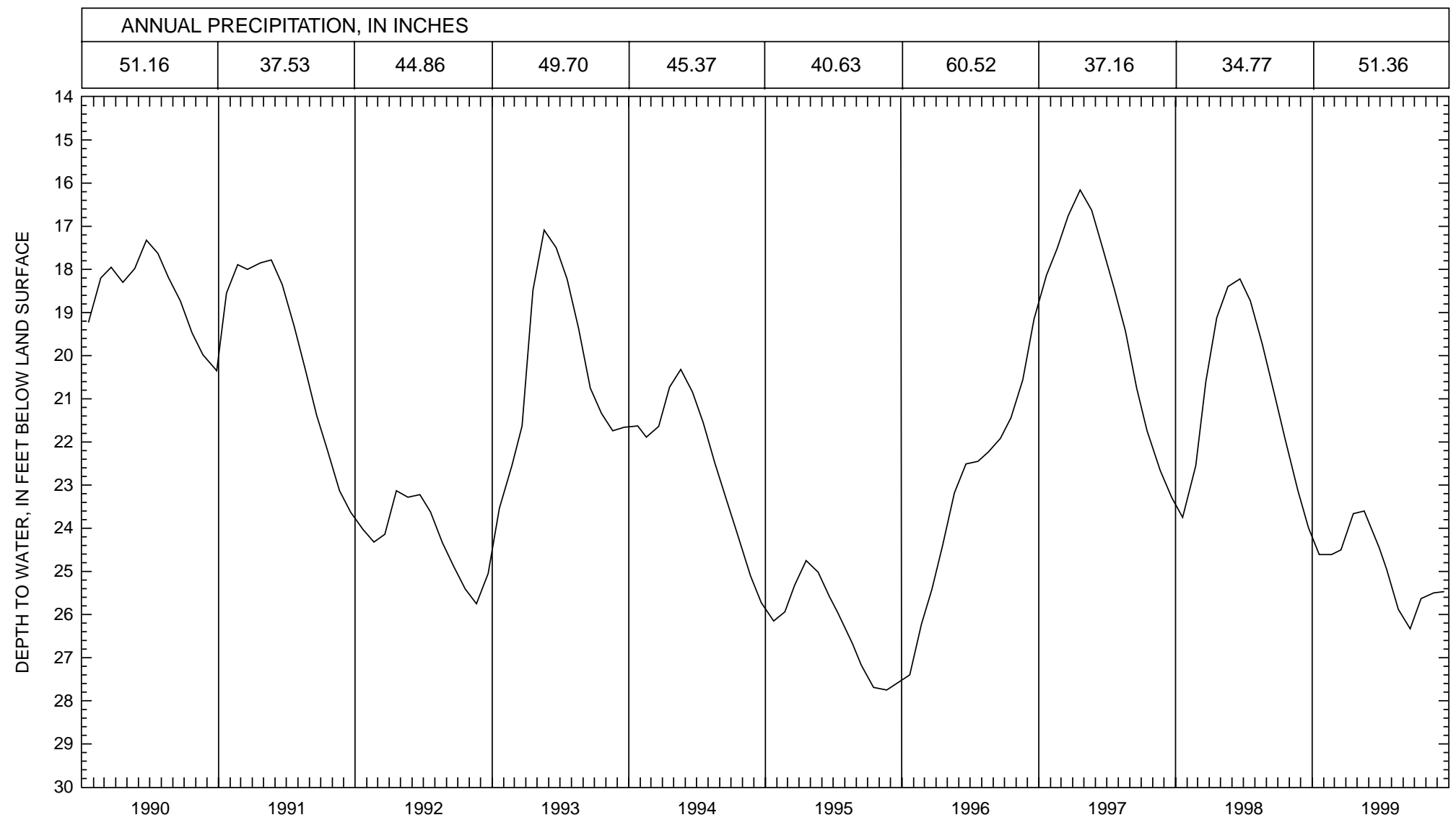

Figure 7. Depth to water in well CH-254, 1990-99, Big Elk Creek Basin, Chester County, Pennsylvania. (Precipitation data are from the National Oceanic and Atmospheric Administration Newark, Delaware, station.) 


\section{Surface Water}

Streamflow from $52.6 \mathrm{mi}^{2}$ of the Big Elk Creek Basin has been measured since April 1, 1932, at the USGS streamflow-measurement station 01495000, Big Elk Creek at Elk Mills, Md. Streamflow from $26.8 \mathrm{mi}^{2}$ of the Little Elk Creek Basin was measured from October 1, 1948, to September 30 , 1958, at the USGS streamflow-measurement station 01495500, Little Elk Creek at Childs, Md. The mean daily flow of Big Elk Creek from 1932 through 1999 was $69.1 \mathrm{ft}^{3} / \mathrm{s}$. The mean daily flow of Little Elk Creek for the period of record was $38.2 \mathrm{ft}^{3} / \mathrm{s}$ or $1.43\left(\mathrm{ft}^{3} / \mathrm{s}\right) / \mathrm{mi}^{2}$. The mean daily flow of Big Elk Creek for the same period (1948-58) was $70.4 \mathrm{ft}^{3} / \mathrm{s}$ or $1.34\left(\mathrm{ft}^{3} / \mathrm{s}\right) / \mathrm{mi}^{2}$.

The capacity of a basin to store ground water can be illustrated by flow-duration curves. A flowduration curve is a cumulative frequency curve that shows the percentage of time specified discharges were equaled or exceeded during a given period. The curve describes the flow characteristics of a stream without regard to the sequence of occurrence. The flow-duration curves for Big Elk Creek for water years (October 1 to September 30) 193299 and Little Elk Creek for water years 1949-57 are shown on figure 8 . Flow-duration curves on figure 8 are mean daily flow in cubic feet per second. The flow-duration curve for Big Elk Creek is representative of the long-term probability distribution. The curves have approximately the same slope, indicating little variability of streamflow between the basins. The curve for the Big Elk Creek is positioned higher on the graph because the drainage basin is larger. The slopes start to flatten at 10-percent exceedence, indicating a large contribution of ground-water discharge to streamflow.

\section{Ground-Water/Surface-Water Relations}

The ground-water and surface-water systems are well connected in the Big Elk Creek Basin. In most areas, streams act as drains for the shallow ground-water system and gain water. Potentiometric-surface maps for the Elk Creek Basin in
Chester County (Mohammad 2000; 2001) show water levels in wells near streams are higher than stream elevations, indicating ground water discharges to streams, and most stream reaches are gaining reaches.

Streamflow is composed of base flow and surface runoff. Base flow is ground water discharged to streams. After rainfall or snowmelt, precipitation that does not infiltrate or evaporate enters streams as surface runoff. The proportions of streamflow that are base flow and surface runoff, as well as the relation between rainfall and surface runoff in a basin, depend on the hydrologic characteristics of the basin. Commonly, more surface runoff is observed in small basins with steep slopes and low-permeability soils and rocks than in large basins with shallow slopes and high-permeability soils and rocks. In urbanized areas, pavement or other land cover with low permeability reduces natural infiltration and can increase the intensity and volume of surface runoff relative to that in undeveloped areas.

The quantity of ground water discharged to streams is related to the altitude of the water table near the stream. Olmsted and Hely (1962) found a linear relation between the monthly average ground-water level in index wells and the base flow of Brandywine Creek during winter months. The relation among precipitation, the water level measured in well CE Ae 9, and streamflow and base flow at the streamflow-measurement station Big Elk Creek at Elk Mills during 1998-99 is shown on figure 9 . The shapes of the base-flow hydrograph and water-level hydrograph are very similar. Base flow generally declines as ground-water levels decline and increases as ground-water levels increase. The time of lowest base flow generally coincides with the lowest ground-water levels. Precipitation during the summer (June through September) generally produces little increase in ground-water levels; most infiltrated precipitation replenishes soil moisture and does not recharge the ground-water system. 


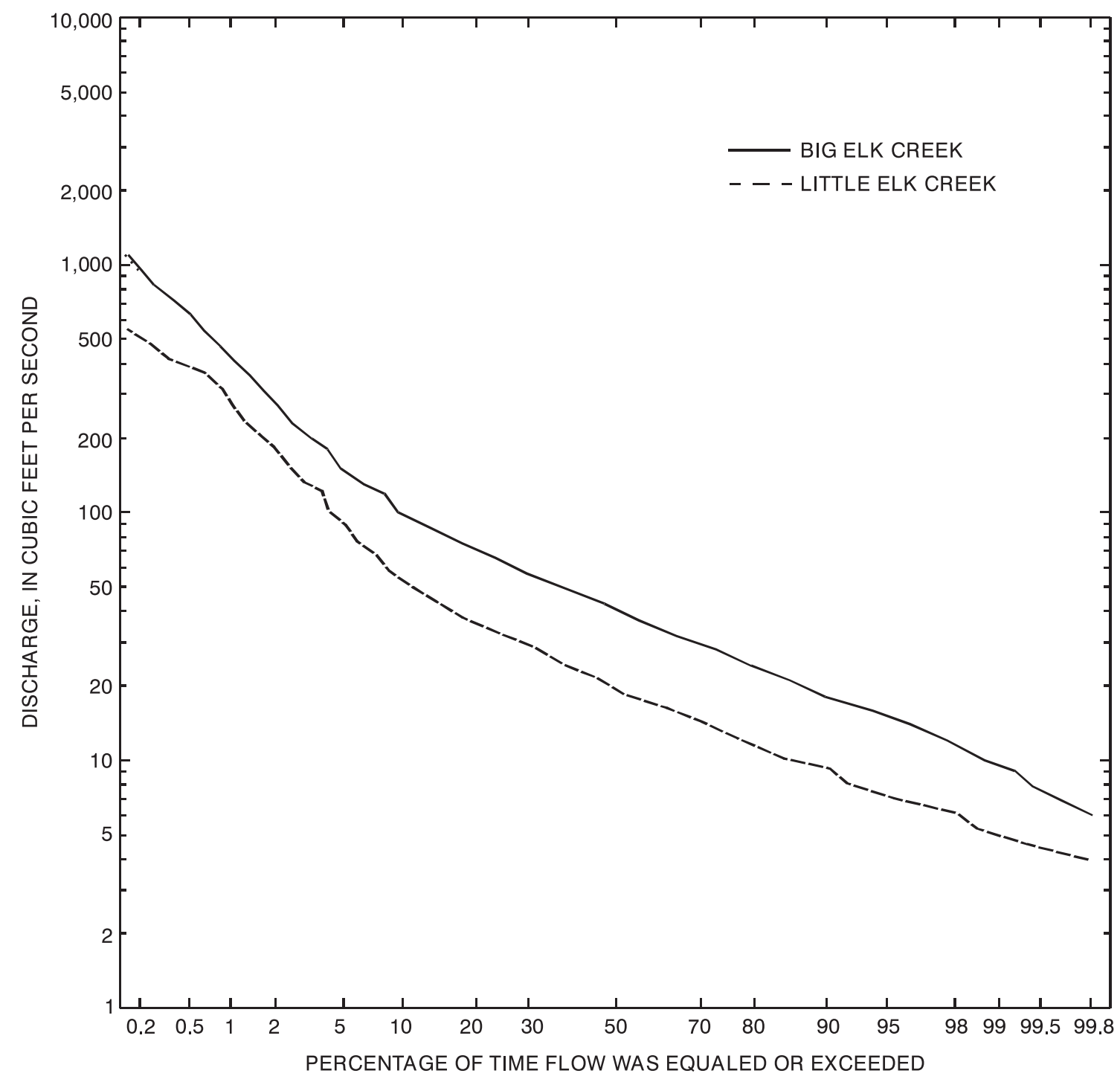

Figure 8. Duration of mean daily flow of Big Elk Creek Creek at Elk Mills, Maryland (station 01495000), water years 1933-99, and Little Elk Creek at Childs, Maryland (station 01495500), water years 1949-57. 

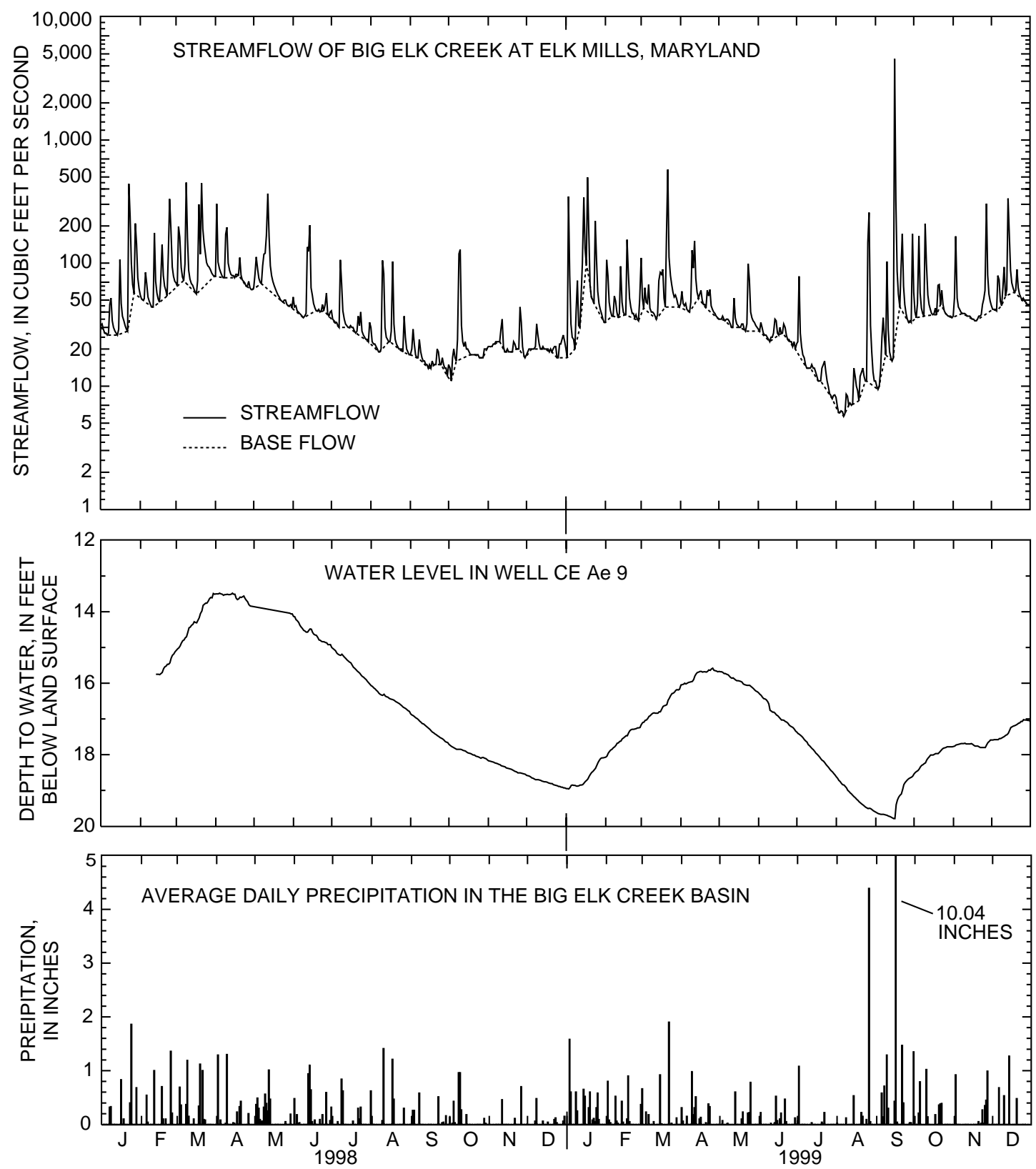

Figure 9. Relation among precipitation, ground-water levels, and streamflow, 1998-99, Big Elk Creek Basin, Pennsylvania and Maryland. 


\section{Base Flow}

Streamflow can be separated into base-flow and surface-runoff components by use of hydrograph-separation techniques (see fig. 9 for an example). Hydrographs for Big Elk Creek and Little Elk Creek for their period of record were separated into base-flow and surface-runoff components (table 6) by use of the local-minimum technique of the computer program of Sloto and Crouse (1996). A detailed discussion of hydrograph separation for Pennsylvania streams is given by White and Sloto (1991). The median base flow for Big Elk Creek in table 6 is representative of the long-term average. Streamflow, base flow, and surface runoff in table 6 are expressed in inches so that basins with different drainage areas can be easily compared. Inches can be converted to million gallons per day per square mile by multiplying by 0.048 . A comparison between the period of record (1949-57 calendar years) for Little Elk Creek at Childs, Md., and the same period for Big Elk Creek at Elk Mills, Md., is provided in table 6 . The median annual base flow for both streams is similar (10.59 in. for Big Elk Creek and 10.64 in. for Little Elk Creek). The percentage of streamflow as base flow is higher for Big Elk Creek (65.2 percent) than for Little Elk Creek (59.4 percent) because the median total flow for Big Elk Creek (16.25 in.) is less than the median total flow for Little Elk Creek (17.50 in.).
In the Big Elk Creek Basin, the median annual base flow (ground-water discharge to the stream) for calendar years 1933-99 was $10.79 \mathrm{in}$. or $0.518(\mathrm{Mgal} / \mathrm{d}) / \mathrm{mi}^{2}$, which was 63 percent of the median annual streamflow (table 6 ). The annual ground-water discharge to streams ranged from 5.32 in. or $0.255(\mathrm{Mgal} / \mathrm{d}) / \mathrm{mi}^{2}$ in 1966 to $17.98 \mathrm{in}$. or $0.863(\mathrm{Mgal} / \mathrm{d}) / \mathrm{mi}^{2}$ in 1972 . Median annual surface runoff for 1933-99 was 6.22 in., which was 37 percent of the median annual streamflow (table 6). The quantity of precipitation that becomes surface runoff depends on the season; the form (rain or snow), intensity, and duration of precipitation; and soil-moisture conditions. Frozen ground and snowmelt also may be contributing factors.

For part of the Delaware River Basin in southeastern Pennsylvania, the Delaware River Basin Commission has set a maximum ground-water withdrawal limit equal to the 25-year annual base flow recurrence (Delaware River Basin Commission, 1999, p. 30). Annual base flows for Big Elk Creek at Elk Mills for calendar years 1933-99 are shown on figure 10, which is a base-flow-frequency curve. A base-flow-frequency curve relates magnitude of base flow to frequency of occurrence. From this base-flow-frequency curve, the 25-year annual base-flow recurrence is 8.52 in., which is equal to $0.409(\mathrm{Mgal} / \mathrm{d}) / \mathrm{mi}^{2}$.

Table 6. Annual streamflow and estimated annual base flow for Big Elk Creek and Little Elk Creek, Pennsylvania and Maryland,1933-99

\begin{tabular}{lcclcc}
\hline & $\begin{array}{c}\text { Total streamflow } \\
\text { (inches) } \\
\text { and year }\end{array}$ & $\begin{array}{c}\text { Estimated base } \\
\text { flow (inches) } \\
\text { and year }\end{array}$ & $\begin{array}{c}\text { Percentage of } \\
\text { streamflow as } \\
\text { base flow and year }\end{array}$ & $\begin{array}{c}\text { Estimated surface } \\
\text { runoff (inches) } \\
\text { and year }\end{array}$ & $\begin{array}{c}\text { Percentage of } \\
\text { streamflow as } \\
\text { surface runoff }\end{array}$ \\
\hline Big Elk Creek, 1933-99 & & & & \\
Minimum & $8.65(1966)$ & $5.32(1966)$ & $49.2(1942)$ & $2.47(1954)$ & $23.6(1997)$ \\
Maximum & $33.01(1996)$ & $17.98(1972)$ & $76.4(1997)$ & $15.94(1966)$ & $50.8(1949)$ \\
Median & 17.04 & 10.79 & 63.0 & 6.22 & 37.0 \\
Big Elk Creek, 1949-57 & & & & \\
Minimum & $9.91(1954)$ & $7.45(1954)$ & $54.4(1955)$ & $2.47(1954)$ & $24.9(1954)$ \\
Maximum & $26.13(1952)$ & $16.57(1952)$ & $73.6(1949)$ & $9.56(1952)$ & $45.6(1955)$ \\
Median & 16.25 & 10.59 & 65.2 & 5.66 & 34.9 \\
Little Elk Creek, $1949-57$ & & & & \\
Minimum & $10.04(1954)$ & $7.32(1954)$ & $48.6(1955)$ & $2.73(1954)$ & $27.1(1954)$ \\
Maximum & $26.61(1952)$ & $14.80(1952)$ & $72.9(1954)$ & $11.71(1952)$ & $51.4(1955)$ \\
Median & 17.50 & 10.64 & 59.4 & 7.25 & 40.6 \\
\hline
\end{tabular}




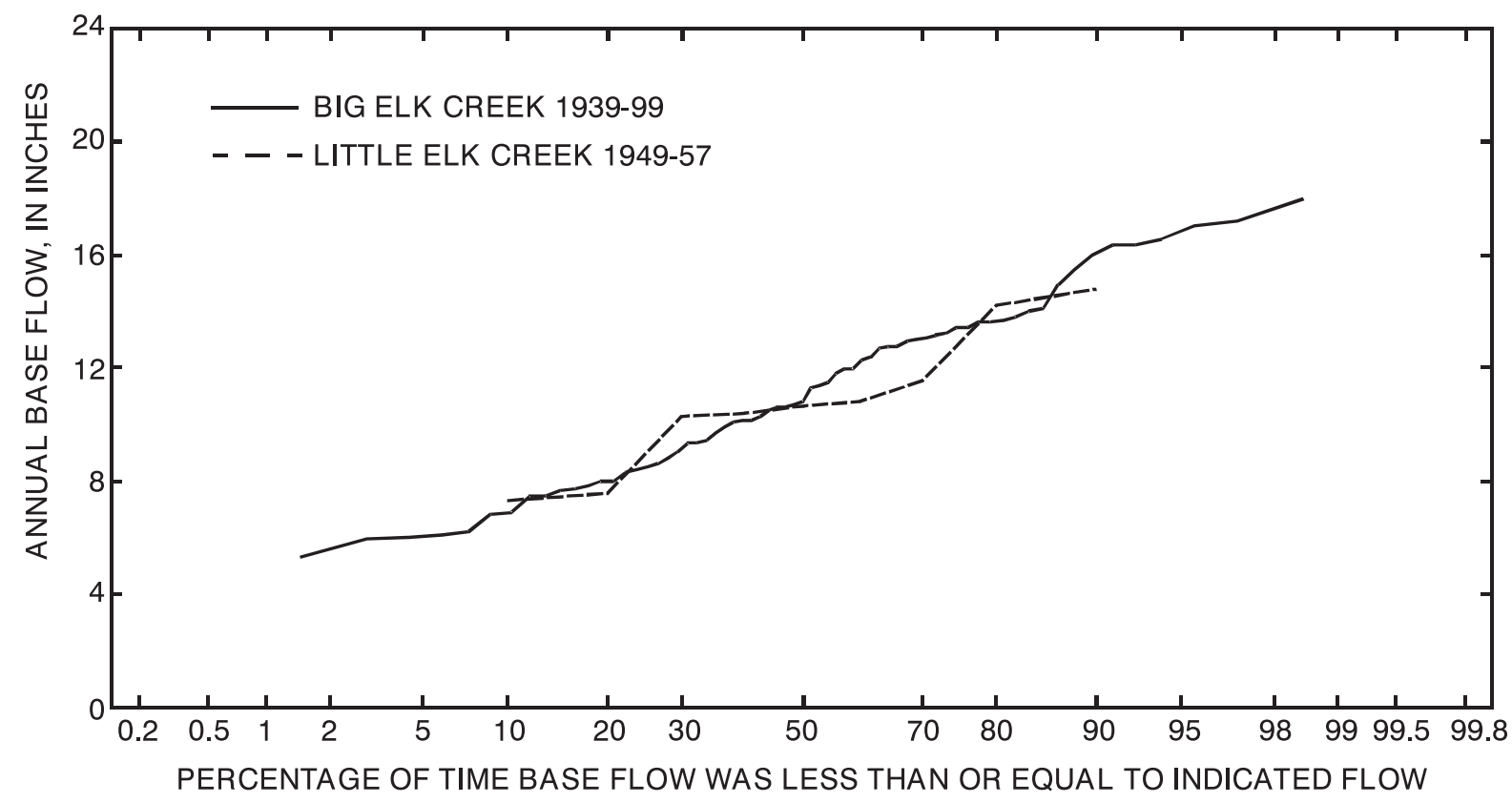

Figure 10. Cumulative annual base-flow frequency of Big Elk Creek Creek at Elk Mills, Maryland (station 01495000), 1933-99, and Little Elk Creek at Childs, Maryland (station 01495500), 1949-57.

\section{Low-Flow Statistics}

Low-flow statistics for the Big Elk Creek Basin were published in Schreffler (1998). Statistical information based on streamflow data can be used to predict future variability of streamflow, not in terms of specific events but in terms of probability of occurrence over a span of years. Low-flow statistics are derived from long-term streamflow data. The long-term data are used to calculate historical low flows and their frequency of occurrence. A statistic typically determined to characterize low flow is the 7-consecutive day, 10-year (7Q10 or $\mathrm{Q}_{7-10}$ ) low-flow value. The 7Q10 is defined as the lowest mean streamflow over 7 consecutive days, which, on average, has and probably will occur once every 10-year period. The $7 Q 10$ is of particular importance to wastewater dischargers. The 7Q10 commonly is adopted by regulators as the minimum flow to define discharge and instream pass-by permit conditions to protect stream-water quality.

Low-flow statistics determined by Schreffler (1998) include the 1-day 10-year (1Q10), 7Q10, and 30-consecutive-day 10 year (30Q10) low-flow values (table 7). These statistics are based on the minimum average 1-day, 7-day, and 30-day flow from each year of record with a recurrence interval of 10 years (cumulative probability of 0.10 ).

A 7Q10 of $1.0 \mathrm{ft}^{3} / \mathrm{s}$ means the probability is 1 in 10 that the annual minimum average 7 -consecutiveday streamflow for any year will be less than

Table 7. Low-flow statistics for streamflow-measurement station Big Elk Creek at Elk Mills, Md. (station 01495000), based on log Pearson Type III frequency distribution (from Schreffler (1998, p.15))

[1Q10, 1-day, 10-year low-flow value; 7Q10, 7-day, 10-year low-flow value; 30Q10, 30-day, 10-year low-flow value; $\mathrm{ft}^{3} / \mathrm{s}$, cubic foot per second]

\begin{tabular}{ccccc}
\hline $\begin{array}{c}\text { Period of } \\
\text { record }\end{array}$ & $\begin{array}{c}\text { LQ10 } \\
\left(\mathbf{f t}^{3} / \mathbf{s}\right)\end{array}$ & $\begin{array}{c}\mathbf{7 Q 1 0} \\
\left(\mathrm{ft}^{3} / \mathbf{s}\right)\end{array}$ & $\begin{array}{c}\mathbf{3 0 Q 1 0} \\
\left(\mathbf{f t}^{3} / \mathbf{s}\right)\end{array}$ & $\begin{array}{c}\text { Harmonic mean } \\
\left(\mathbf{f t}^{3} / \mathbf{s}\right)\end{array}$ \\
\hline April 1932-94 & 9.1 & 10.3 & 12.8 & 37.6 \\
\hline
\end{tabular}


$1.0 \mathrm{ft}^{3} / \mathrm{s}$, or that the annual minimum average 7 -consecutive-day streamflow of less than $1.0 \mathrm{ft}^{3} / \mathrm{s}$ should be expected at the site, on average, once every 10 years. Low-flow data were analyzed by Schreffler (1998) on the basis of a climatic year (April 1 to March 31). This period was used so that streamflow through the entire low-flow season, generally July through October, is included within the year. Schreffler also determined an additional low-flow statistic, the harmonic mean (table 7). The harmonic mean is determined by summing the inverses of daily mean streamflow data for the entire period of record and dividing the resulting sum into the number of data values. In Pennsylvania, the harmonic mean may be used to evaluate effects on surface water from diffuse flow of contaminated ground water under regulations of the Pennsylvania Department of Environmental Protection Land Recycling Program.

\section{Ground-Water Availability}

Ground-water availability is defined and estimated in a number of ways. It commonly is based on the concept of "safe yield," "optimal basin yield," or "perennial yield." Todd (1980, p. 363) defines "perennial yield" as the rate at which water can be withdrawn perennially from a ground-water basin under specified operating conditions without producing an undesired result. Undesired results may differ from basin to basin depending on socioeconomic and legal viewpoints and can include reduced streamflow, reduced base flow, reduced ground-water levels, well interference, and degradation of water quality.

Methods to determine ground-water availability in a basin include determinations of average annual recharge (commonly assumed to be equal to average annual base flow), dry-year base flow (McGreevy and Sloto, 1977), 1-year in 25 average annual base flow (Delaware River Basin Commission, 1999, p. 30), and the 7Q10 or a percentage of it [proposed by the Green Valleys Association (2000, p. 5-10 and 5-11) as a limit for ground-water sustainability]. A comparison of withdrawal rates using these methods is presented in table 8.

The optimal method is the one that best meets a set of socioeconomic and/or social and environmental objectives associated with the use of the water. However, all the methods indicate there will be sufficient ground water on a basin-wide scale to meet the $162 \mathrm{Mgal}$-per-year increase in demand projected to 2020 (Chester County Water Resources Authority, 2001).

Table 8. Ground-water availability in the Big Elk Creek Basin, Pennsylvania and Maryland

[7Q10, 7-day, 10-year low-flow value]

\begin{tabular}{lcc}
\hline \multirow{2}{*}{ Method of availability determination } & \multicolumn{2}{c}{ Withdrawal rate } \\
\cline { 2 - 3 } & $\begin{array}{c}\text { Million gallons per day } \\
\text { per square mile }\end{array}$ & $\begin{array}{c}\text { Gallons per day } \\
\text { per acre }\end{array}$ \\
\hline Average annual base flow & 0.535 & 836 \\
Median annual base flow & .518 & 809 \\
1-year in 25 average annual base flow & .409 & 639 \\
Dry-year base flow (1966) & .255 & 389 \\
7Q10 & .127 & 198 \\
\hline
\end{tabular}




\section{Water Budget}

A water budget is an estimate of water entering and leaving a basin plus or minus storage changes for a given time period. A water budget quantifies the hydrologic cycle and defines the water balance for a basin. Water enters as precipitation and leaves as streamflow, evapotranspiration (ET), and diversions, such as exported water. Water also is taken into or released from ground-water and soilmoisture storage. Sewer systems can import or export water into or out of a basin.

Because the water budgets in this report begin and end in winter when soil moisture usually is at field capacity, the change in soil moisture is assumed to be equal to zero, and a soil-moisture term is not included in the water-budget equation. Therefore, for basins where ground-water and surface-water divides coincide, such as the Big Elk Creek Basin, a simple annual water budget can be expressed as

$$
\mathrm{P}=\mathrm{SF}+\Delta \mathrm{GWS}+\mathrm{ET}+\mathrm{GWEXP}
$$

where $P$ is precipitation,

$S F$ is streamflow,

$\triangle G W S$ is change in ground-water storage,

$E T$ is evapotranspiration and other losses, and

GWEXP is ground water exported from the basin

All terms in the water-budget equation can be measured or estimated except ET; and, therefore, equation 1 is solved for ET.

Equation 1 was used to calculate water budgets for the Big Elk Creek Basin for 1998-99 (table 9). The water budget is expressed in inches so that water budget components can be related to precipitation and compared to other basins with different drainage areas. Inches can be converted to million gallons per day per square mile by multiplying by 0.048 . Data-collection sites necessary to calculate a water budget include one or more pre- cipitation gages $(P)$, a streamflow-measurement station (SF), and observation wells to estimate the change in ground-water storage $(\Delta G W S)$. The location of data-collection stations in the Big Elk Creek Basin is shown on figure 6.

Precipitation data for the Big Elk Creek Basin were collected at nine sites by volunteer observers. Annual precipitation in table 9 is the sum of average monthly precipitation measured at those gages. Precipitation for 1998 (41.04 in.) is below the normal (45.35 in.) for Newark, Del. The total precipitation for 1999 (53.31 in.) was above the normal for Newark, Del. Precipitation from the storm of August 26-27, 1999, was 4.38 in., and precipitation from Hurricane Floyd (September 16, 1999) was $10.04 \mathrm{in}$. If the 14.42 in. of precipitation from these two storms were subtracted from the annual total, precipitation for 1999 would be 38.89 in., which is below the normal for Newark, Del.

Streamflow was measured at the streamflowmeasurement station Big Elk Creek at Elk Mills, Md. On the basis of the streamflow record, the surface runoff from Hurricane Floyd was 3.48 in. However, precipitation was 10.04 in., and it is unlikely that all the remaining 6.56 in. of water infiltrated or evaporated. This discrepancy is reflected in the ET term and may cause ET to be overestimated in the water budget for 1999 .

Ground-water storage is the water in and moving through the ground-water system. A positive change (gain) in ground-water storage indicates an increase in the volume of water in the ground-water system. A negative change (loss) in ground-water storage indicates a decrease in the volume of water in the ground-water system. Water-level data from January of each year from 10 observation wells (table 19) were used to calculate the annual change in ground-water storage. The median

Table 9. Annual water budgets for the Big Elk Creek Basin, Pennsylvania and Maryland, 1998-99

[A negative number indicates a decrease in ground-water storage.]

\begin{tabular}{lccccccc}
\hline Year & $\begin{array}{c}\text { Precipitation } \\
\text { (inches) }\end{array}$ & $\begin{array}{c}\text { Streamflow } \\
\text { (inches) }\end{array}$ & $\begin{array}{c}\text { Percentage of } \\
\text { precipitation as } \\
\text { streamflow }\end{array}$ & $\begin{array}{c}\text { Change in } \\
\text { ground- } \\
\text { water } \\
\text { storage } \\
\text { (inches) }\end{array}$ & $\begin{array}{c}\text { Ground- } \\
\text { water } \\
\text { exports } \\
\text { (inches) }\end{array}$ & $\begin{array}{c}\text { Evapotranspiration } \\
\text { and other losses } \\
\text { (inches) }\end{array}$ & $\begin{array}{c}\text { Percentage of } \\
\text { precipitation as } \\
\text { evapotranspiration }\end{array}$ \\
\hline 1998 & 41.04 & 14.22 & 34.7 & -0.12 & 0.03 & 26.91 & 34.11 \\
1999 & 53.31 & 16.54 & 31.0 & 2.76 & .02 & 65.6 \\
Average & 47.18 & 15.38 & 37.5 & 1.32 & .03 & 30.50 & 64.8 \\
\hline
\end{tabular}


annual change in water level was multiplied by 0.08 , the specific yield of the zone of water-level fluctuation in crystalline rocks (McGreevy and Sloto, 1980, p. 18), to calculate the annual change in ground-water storage. Annual changes in water level ranged from 3.07 to $-3.15 \mathrm{ft}$ for 1998 with an average change of $-0.12 \mathrm{ft}$. Annual changes in water level ranged from 6.92 to $-1.48 \mathrm{ft}$ for 1999 with an average change of $2.76 \mathrm{ft}$. The rise in water level caused by recharge from the August 26-27, 1999, storm and Hurricane Floyd calculated by comparing the August 18 and September 22, 1999, measurements ranged from -0.45 to $5.72 \mathrm{ft}$ with an average rise of $2.71 \mathrm{ft}$.

Ground water is exported from wells pumped in the basin by the Oxford Borough Water Department. The Oxford Borough Water Department pumped 93.2 Mgal in 1998 and 82.2 Mgal in 1999 from the Big Elk Creek Basin. The Oxford Sewer Authority uses a spray irrigation system for disposal in the Big Elk Creek Basin. The quantity of effluent sprayed was $62 \mathrm{Mgal}$ in 1998 and 63.5 Mgal in 1999. The percentage of the effluent that recharged the ground-water system is unknown. Assuming that 50 percent of the effluent is returned to the ground-water system as recharge, the net ground-water export from the basin was 31.2 and 18.7 Mgal for 1998 and 1999, respectively. This is equal to $0.03 \mathrm{in} / \mathrm{yr}$ for 1998 and $0.02 \mathrm{in} / \mathrm{yr}$ for 1999

The ET term in the water budget includes ET, other losses, and errors in the measurement of the other water-budget components. Estimated ET calculated using equation 1 was 26.91 and 34.10 in. for 1998 and 1999, respectively. Despite a 12.27-in. difference in precipitation between 1998 and 1999, the percentage of precipitation as ET (65.6 and 64 percent, respectively) is similar (table 9).

\section{Recharge}

All natural recharge to the ground-water system in the Big Elk Creek Basin is derived from local precipitation. Some additional recharge is derived from the Oxford Sewer Authority spray irrigation system. Infiltrated precipitation first replenishes soil moisture. After the soil-moisture deficit has been satisfied, infiltrated precipitation recharges the ground-water system. Recharge to the groundwater system depends on many factors, including the duration and intensity of precipitation, antecedent soil-moisture conditions, slope, quantity of impervious surface areas associated with urbanization, and soil and bedrock characteristics. Recharge varies from season to season and from year to year. Generally, recharge occurs on hilltops and hillsides; topographically low areas commonly are discharge areas.

Annual recharge was estimated for the Big Elk Creek Basin for 1998-99 (table 10) by the following equation:

$$
\begin{aligned}
& \mathrm{R}=\mathrm{BF}+\Delta \mathrm{GWS}+\mathrm{GWET}+\mathrm{GWEXP}, \text { (2) } \\
& \text { where } R \text { is estimated recharge, } \\
& B F \text { is base flow, } \\
& \Delta G W S \text { is change in ground-water storage, } \\
& \text { GWET is estimated ground-water } \\
& \quad \text { evapotranspiration, and } \\
& \text { GWEXP is ground water exported from the basin. }
\end{aligned}
$$

Base flow was estimated by the local minimum computer hydrograph-separation technique of Sloto and Crouse (1996). Ground-water ET is ET directly from the saturated zone; it takes place where the water table is close to the land surface. Ground-water ET is estimated to be about 2 in/yr on the basis of simulations of hydrologic budgets using a ground-water-flow model by Sloto (1991). Olmsted and Hely (1962, p. 13) estimated an annual ground-water ET of 5.5 in/yr for the Piedmont. Most observation wells used to calculate change in ground-water storage do not have water levels close to land surface; therefore, loss to

Table 10. Estimated annual recharge for the Big Elk Creek Basin, Pennsylvania and Maryland, 1998-99

[A negative number indicates a decrease in ground-water storage.]

\begin{tabular}{llccccc}
\hline Year & $\begin{array}{c}\text { Recharge } \\
\text { (inches) }\end{array}$ & $\begin{array}{c}\text { Percentage of } \\
\text { precipitation as } \\
\text { recharge }\end{array}$ & $\begin{array}{c}\text { Base flow } \\
\text { (inches) }\end{array}$ & $\begin{array}{c}\text { Change in } \\
\text { ground-water } \\
\text { storage } \\
\text { (inches) }\end{array}$ & $\begin{array}{c}\text { Estimated } \\
\text { ground-water } \\
\text { evapotranspiration } \\
\text { (inches) }\end{array}$ & $\begin{array}{c}\text { Ground-water } \\
\text { exports } \\
\text { (inches) }\end{array}$ \\
\hline 1998 & 11.28 & 27.4 & 9.37 & -0.12 & 2.00 & 0.03 \\
1999 & 12.95 & 24.3 & 8.28 & 2.76 & 2.00 & .02 \\
Average & 12.12 & 25.9 & 8.83 & 1.32 & 2.00 & .03 \\
\hline
\end{tabular}


ground-water ET is not reflected in water levels from these wells. Estimated recharge in table 10 is given in inches so that recharge can be related to precipitation and compared to other basins with different drainage areas. Inches can be converted to million gallons per day per square mile by multiplying by 0.048 .

Estimated recharge calculated using equation 2 was 11.28 in. $\left[0.540(\mathrm{Mgal} / \mathrm{d}) / \mathrm{mi}^{2}\right]$ in 1998 , and 12.95 in. $\left[0.621(\mathrm{Mgal} / \mathrm{d}) / \mathrm{mi}^{2}\right]$ in 1999 . Average estimated annual recharge for 1998-99 was $12.12 \mathrm{in.}$ [0.580 $\left.(\mathrm{Mgal} / \mathrm{d}) / \mathrm{mi}^{2}\right]$; this is equal to a recharge rate of $909 \mathrm{gal} / \mathrm{d}$ per acre. Recharge as a percentage of precipitation was 27.4 percent for 1998 and 24.3 percent for 1999, respectively. Average annual recharge for $1998-99$ as a percentage of average annual precipitation was 25.9 percent.

\section{GROUND-WATER QUALITY}

The quality of water is determined primarily by the type and quantity of substances dissolved in it. As water moves through the hydrologic cycle, gases and minerals from the atmosphere, soil, and rock are dissolved. Additional substances may be added by anthropogenic activities. Nutrients from septic systems and fertilizers, salts from road salting and septic systems, pesticides, and industrial solvents and chemicals can be introduced into ground water. Biological activity also can change the chemical composition of ground water.

Major ions dissolved from soil and rock make up most dissolved solutes in ground water; the remainder mostly comes from constituents dissolved in precipitation. Major cations (positively charged ions) are calcium $\left(\mathrm{Ca}^{+2}\right)$, sodium $\left(\mathrm{Na}^{+}\right)$, magnesium $\left(\mathrm{Mg}^{+2}\right)$, and potassium $\left(\mathrm{K}^{+}\right)$. Major anions (negatively charged ions) are bicarbonate $\left(\mathrm{HCO}_{3}^{-}\right)$, sulfate $\left(\mathrm{SO}_{4}^{-2}\right)$, chloride $\left(\mathrm{Cl}^{-}\right)$, nitrate $\left(\mathrm{NO}_{3}{ }^{-}\right)$, and fluoride $\left(\mathrm{F}^{-}\right)$. Silica $\left(\mathrm{SiO}_{2}\right)$ is a major constituent commonly present as undissociated silicic acid $\left(\mathrm{H}_{4} \mathrm{SiO}_{4}\right)$, an uncharged ion, below a pH of 10 .

Precipitation is the primary source of water for the ground-water system in the Big Elk Creek Basin. Precipitation contains trace and major elements scavenged from the atmosphere. The source of constituents in precipitation can be natural, such as sodium and chloride from the ocean, or anthropogenic, such as sodium and chloride from road salt. Atmospheric precipitation commonly is a major source of chloride and nitrogen. The average concentration of selected major ions in precipitation in Chester County is given by Sloto (1994, p. 57) and summarized by Senior and others (1997, p. 47). Precipitation quality in the Big Elk Creek Basin should be similar. For typical precipitation in Pennsylvania, the dominant anions are sulfate and nitrate, and the dominant cations are hydrogen and ammonium. Rain from summer storms is relatively enriched in sodium and chloride from the ocean, and precipitation from winter storms is relatively enriched in sulfur and nitrogen from the burning of fossil fuels.

$\mathrm{pH}$ is a measurement of the activity of hydrogen ions in water and is expressed in logarithmic units with a $\mathrm{pH}$ of 7 considered neutral. Water with a $\mathrm{pH}$ less than 7 is acidic; water with a $\mathrm{pH}$ greater than 7 is basic. The $\mathrm{pH}$ of distilled water in contact with the atmosphere is about 5.6 because of dissolution of carbon dioxide. However, in southeastern Pennsylvania where emissions from combustion of fossil fuels contribute to acidity of atmospheric precipitation, the $\mathrm{pH}$ commonly is less than 5 . The median $\mathrm{pH}$ measured by Lynch and others (1992) for 1982-91 was 4.24. Acidic precipitation can react aggressively with some minerals to accelerate mineral weathering.

Ground-water composition evolves through a series of chemical interactions with minerals in the aquifer. Some chemical reactions are mediated biologically, such as denitrification, during which nitrate is reduced to nitrogen gas. The main chemical reactions are mineral dissolution and precipitation, mineral weathering, ion adsorption and exchange, and natural radioactive decay. Sources of many elements in natural waters and general and important chemical reactions governing water chemistry are summarized by Hem (1985).

In crystalline rocks, silicate minerals are the most abundant minerals. These minerals can include feldspars, micas, and quartz. Other minerals that may be present are pyrite (a sulfide), secondary iron and manganese hydroxides, and traceelement oxides. The weathering of feldspars and micas causes an increase in alkalinity, $\mathrm{pH}$, and concentrations of dissolved silica, sodium, calcium, magnesium, and/or potassium. The weathering of pyrite can cause an increase in the concentration of dissolved sulfate and a decrease in $\mathrm{pH}$.

For this study, water samples were collected from 20 wells for analysis for inorganic constituents and pesticides. The USGS has collected and analyzed ground-water samples in the Big Elk Creek 
Basin since 1925, and data were available from an additional 44 wells. A few wells are at or just over the drainage divide. These data were collected for previous studies and for a ground-water-quality sampling program conducted by the USGS in cooperation with the Chester County Water
Resources Authority and the Chester County Health Department. Ground-water samples were analyzed by the USGS. Complete analyses are given in tables 20 and 21 . Locations of sampled wells are shown on figure 11 .

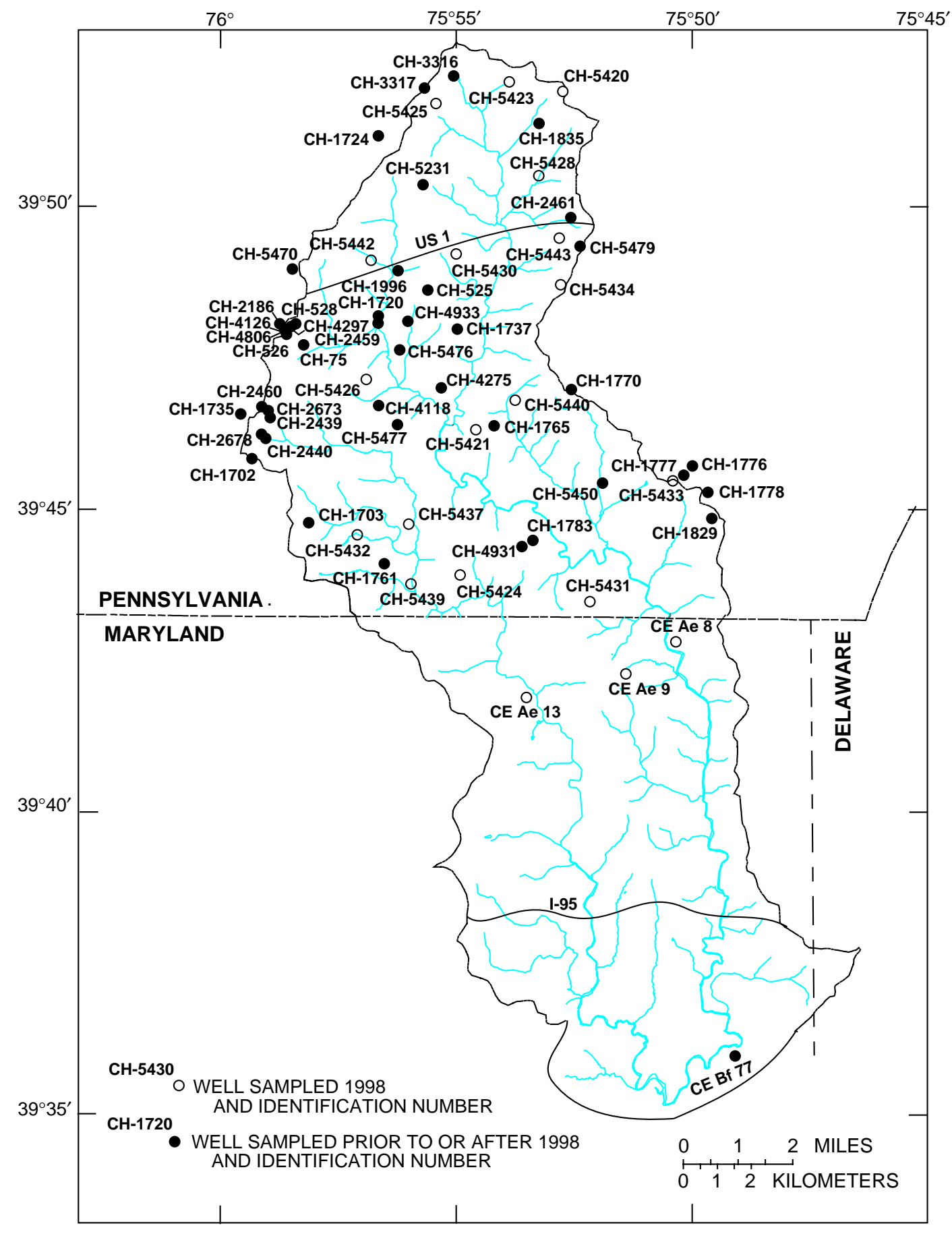

Figure 11. Location of wells sampled for water-quality analyses, Big Elk Creek Basin, Pennsylvania and Maryland. 


\section{Physical Properties and Field-Determined Constituents}

Water quality may be characterized by physical properties and the concentration of dissolved and suspended constituents. Physical properties and chemical constituents determined in the field include $\mathrm{pH}$, specific conductance, hardness, alkalinity, temperature, and the concentration of dissolved oxygen; these properties are unstable and are measured in the field at the time a water sample is collected.

The range and median $\mathrm{pH}$, specific conductance, alkalinity, hardness, temperature, and concentration of dissolved oxygen in ground water in the Big Elk Creek Basin are presented in table 11.
Complete chemical analyses are given in table 20 . The $\mathrm{pH}$, alkalinity, and dissolved-oxygen concentration were measured in the field according to established procedures (Wood, 1981). Where more than one analysis of water was available for a well, the most recent one was used for statistical analysis. Extreme values may represent anthropogenic contamination.

The median $\mathrm{pH}$ of water (5.9) from wells in the Wissahickon Schist is acidic. Only three water samples were collected from serpentinite; the $\mathrm{pH}$ ranged from 7.8 to 8.5. McGreevy and Sloto (1977, p. 47) reported the median $\mathrm{pH}$ of ground water in serpentinite was 8.1 .

Table 11. Summary of physical properties and field-determined constituents for water samples from wells in the Big Elk Creek Basin, Pennsylvania and Maryland

$\left[{ }^{\circ} \mathrm{C}\right.$, degrees Celsius; $\mu \mathrm{S} / \mathrm{cm}$, microsiemens per centimeter at 25 degrees Celsius; $\mathrm{mg} / \mathrm{L}$, milligrams per liter; --, insufficient data to compute median]

\begin{tabular}{|c|c|c|c|c|}
\hline $\begin{array}{l}\text { Property or constituent and } \\
\text { geologic unit }\end{array}$ & $\begin{array}{l}\text { Number of } \\
\text { samples }\end{array}$ & Minimum & Median & Maximum \\
\hline \multicolumn{5}{|l|}{$\overline{\mathrm{pH}}$} \\
\hline Peters Creek Schist & 4 & 4.8 & -- & 7.1 \\
\hline Serpentinite & 3 & 7.8 & -- & 8.5 \\
\hline Wissahickon Schist & 48 & 5.2 & 5.9 & 7.7 \\
\hline Pelitic gneiss & 2 & 6 & -- & 6.6 \\
\hline \multicolumn{5}{|l|}{ Specific conductance $(\mu \mathrm{S} / \mathrm{cm})$} \\
\hline Peters Creek Schist & 4 & 54 & -- & 500 \\
\hline Serpentinite & 3 & 396 & -- & 457 \\
\hline Wissahickon Schist & 46 & 50 & 160 & 849 \\
\hline Pelitic gneiss & 3 & 128 & -- & 699 \\
\hline \multicolumn{5}{|l|}{ Alkalinity $\left(\mathrm{mg} / \mathrm{L}\right.$ as $\left.\mathrm{CaCO}_{3}\right)$} \\
\hline Peters Creek Schist & 2 & 2 & -- & 18 \\
\hline Serpentinite & 1 & 243 & -- & -- \\
\hline Wissahickon Schist & 34 & 6 & 20 & 90 \\
\hline Pelitic gneiss & 0 & -- & -- & -- \\
\hline \multicolumn{5}{|l|}{ Hardness $^{1}\left(\mathrm{mg} / \mathrm{L}\right.$ as $\left.\mathrm{CaCO}_{3}\right)$} \\
\hline Peters Creek Schist & 3 & 13 & -- & 80 \\
\hline Serpentinite & 3 & 220 & -- & 250 \\
\hline Wissahickon Schist & 41 & 9 & 38 & 99 \\
\hline Pelitic gneiss & 3 & 42 & -- & 320 \\
\hline \multicolumn{5}{|l|}{ Temperature $\left({ }^{\circ} \mathrm{C}\right)$} \\
\hline Peters Creek Schist & 2 & 13.5 & -- & 15 \\
\hline Serpentinite & 3 & 13.7 & -- & 18.1 \\
\hline Wissahickon Schist & 40 & 11.5 & 13.6 & 18 \\
\hline Pelitic gneiss & 3 & 12.9 & -- & 13.2 \\
\hline \multicolumn{5}{|l|}{ Dissolved oxygen (mg/L) } \\
\hline Peters Creek Schist & 1 & 9.3 & -- & -- \\
\hline Serpentinite & 1 & 1.8 & -- & -- \\
\hline Wissahickon Schist & 23 & 3.4 & 7.5 & 10 \\
\hline Pelitic gneiss & 0 & -- & -- & -- \\
\hline
\end{tabular}

${ }^{1}$ Includes both laboratory determinations and computed values. 
Specific conductance is a measurement of the ability of water to conduct an electric current and is expressed in units of microsiemens per centimeter at $25^{\circ} \mathrm{C}$. Specific conductance is related directly to the concentration of dissolved solids; the higher the specific conductance, the greater the concentration of dissolved solids. The concentration of total dissolved solids (TDS) can be estimated by multiplying specific conductance by 0.65 (Sloto, 1994 , p. 58). The median specific conductance of water from wells in the Wissahickon Schist is a relatively low $160 \mu \mathrm{S} / \mathrm{cm}$.

The alkalinity of water is the capacity for solutes (bases) it contains to react with and neutralize acid and is expressed in terms of an equivalent amount of calcium carbonate. Alkalinity is produced by dissolution of minerals or reactions that generate bicarbonate, carbonate, or other basic anions. Bicarbonate alkalinity predominates in most natural ground water. The median alkalinity of water from wells in the Wissahickon Schist is $20 \mathrm{mg} / \mathrm{L}$.

Hardness is a poorly defined property of water and is caused by the dissolved alkaline earth elements, chiefly calcium and magnesium. Hard water restricts the lathering and cleaning action of soap and causes the formation of encrustations when water is heated. Hardness usually is expressed in equivalent concentrations of calcium carbonate. Hardness is classified by Dufor and Becker (1964, p. 27) as: soft, 0-60 mg/L; moderately hard, 61 $120 \mathrm{mg} / \mathrm{L}$; hard, 121-180 mg/L; and very hard, more than $180 \mathrm{mg} / \mathrm{L}$. Water from wells in the Wissahickon Schist is soft; the median hardness is $38 \mathrm{mg} / \mathrm{L}$. Only three water samples were collected from serpentinite; the hardness ranged from 220 to $250 \mathrm{mg} / \mathrm{L}$, which would classify the water as very hard.

The median temperature of water samples from wells in the Wissahickon Schist is $13.6^{\circ} \mathrm{C}$ $\left(56.5^{\circ} \mathrm{F}\right)$. Ground-water temperature commonly is similar to the mean annual air temperature. The 1971-2000 normal annual air temperature at the NOAA station in Newark, Del., is $54.8^{\circ} \mathrm{F}\left(12.7^{\circ} \mathrm{C}\right)$. Ground-water temperatures measured monthly from December 1983 to December 1984 in six wells in different parts of Chester County by Sloto (1987) had an average annual fluctuation range of about $3.3^{\circ} \mathrm{C}\left(6^{\circ} \mathrm{F}\right)$.

Dissolved oxygen in ground water indicates infiltration of recharge is rapid and/or few biological and chemical reactions that consume oxygen have taken place. Oxygen can be consumed in the oxidation of organic and inorganic (including minerals) compounds. Ground water in fractured-rock aquifers in the Piedmont commonly contains some dissolved oxygen. For the range of ground-water temperature observed in the basin (11.5 to $18.1^{\circ} \mathrm{C}$ ), the saturated concentration of dissolved oxygen ranges from 6.5 to $11 \mathrm{mg} / \mathrm{L}$ (American Public Health Association and others, 1995, p. 4-99). The concentration of dissolved oxygen in ground water from the Wissahickon Schist ranges from 3.4 to $10 \mathrm{mg} / \mathrm{L}$; the median concentration is $7.5 \mathrm{mg} / \mathrm{L}$. 


\section{Major lons}

Major ions dissolved from soil and rock constitute most of the dissolved solutes in ground water; some solutes are dissolved in precipitation. Major ions, in order of decreasing concentration, in the ground water of the Big Elk Creek Basin, based on median concentrations for the Wissahickon Schist (table 12), are silica, calcium, chloride, sodium, sulfate, magnesium, and potassium. Complete chemical analyses for major ions are given in table 20 .

Because the number of water-quality analyses for wells in geologic units other than the Wissahickon Schist is small, these analyses may not be representative of the water quality of those units. Differences in ground-water quality among geologic units were not tested statistically.

The U.S. Environmental Protection Agency (USEPA) has set maximum contaminant levels (MCL's) and secondary maximum contaminant levels (SMCL's) for some constituents in drinking water (table 13). MCL's usually are set because elevated concentrations of these constituents may cause adverse health effects. SMCL's usually are set for aesthetic reasons; elevated concentrations of these constituents may impart an undesirable taste or odor to water.

Total dissolved solids (TDS) is a measurement of the total solutes in water. Water from crystalline rocks, which are resistant to weathering, generally contain low concentrations of TDS. The USEPA SMCL for TDS concentration in drinking water is $500 \mathrm{mg} / \mathrm{L}$. Water from only 1 of 49 wells sampled (2 percent) in the Big Elk Creek Basin exceeded the SMCL for TDS; a water sample from well CE Ae 9 in the pelitic schist had a TDS concentration of $599 \mathrm{mg} / \mathrm{L}$. The median concentration of TDS in water samples from the Wissahickon Schist is $100 \mathrm{mg} / \mathrm{L}$.

Mineral sources of calcium include calcite $\left(\mathrm{CaCO}_{3}\right)$, dolomite $\left[\mathrm{CaMg}\left(\mathrm{CO}_{3}\right)_{2}\right]$, and anorthite $\left(\mathrm{CaAl} \mathrm{Si}_{2} \mathrm{O}_{8}\right)$ or other calcium-bearing feldspars. Sources of magnesium include dolomite and chlorite $\left[\mathrm{Mg}_{5} \mathrm{Al}_{2} \mathrm{Si}_{3} \mathrm{O}_{10}(\mathrm{OH})_{8}\right]$. Median concentrations of calcium and magnesium in water samples from the Wissahickon Schist are 9.3 and $3.9 \mathrm{mg} / \mathrm{L}$, respectively (table 12). Serpentinite is a calciumdeficient and magnesium-rich rock. The calcium concentration of three water samples from serpentinite ranged from 1.8 to $4.6 \mathrm{mg} / \mathrm{L}$, and the magnesium concentration ranged from 53 to $59 \mathrm{mg} / \mathrm{L}$.
Mineral sources of potassium include mica [muscovite, $\mathrm{KAl}_{3} \mathrm{Si}_{3} \mathrm{O}_{10}(\mathrm{OH})_{2}$ and biotite, $\left.\mathrm{K}(\mathrm{Mg}, \mathrm{Fe})_{3} \mathrm{AlSi}_{3} \mathrm{O}_{10}(\mathrm{OH})_{2}\right]$ and orthoclase, a potassium-bearing feldspar $\left(\mathrm{KAl}_{3} \mathrm{Si}_{3} \mathrm{O}_{8}\right)$, which are abundant in crystalline rocks. Potassium also is a component in fertilizers. The median concentration of potassium in water samples from the Wissahickon Schist is $1.7 \mathrm{mg} / \mathrm{L}$ (table 12).

Mineral sources of sodium include albite $\left(\mathrm{NaAl}_{3} \mathrm{Si}_{3} \mathrm{O}_{8}\right)$ or other sodium-bearing feldspars and clay minerals. Road salt is a source of sodium and may produce elevated sodium concentrations in ground water. The median concentration of sodium in water samples from the Wissahickon Schist is $6.7 \mathrm{mg} / \mathrm{L}$ (table 12). The predominant natural source of chloride in the Big Elk Creek Basin probably is precipitation. Chloride concentrations in precipitation (median $0.5 \mathrm{mg} / \mathrm{L}$, Sloto, 1994, p. 57) can be increased by evaporation before infiltration.

The minimum reported concentrations of chloride in ground water (about 2-6 mg/L) probably represent natural background concentrations (table 20). Chloride concentrations range up to $218 \mathrm{mg} / \mathrm{L}$ (table 12). Elevated concentrations of chloride in the Big Elk Creek Basin probably are caused by anthropogenic activities, such as input from road salt, fertilizers, and septic systems. Increases in chloride concentration commonly are accompanied by increases in sodium. A linear relation between concentrations of sodium and chloride is evident for ground-water samples (fig. 12). If the sole source of sodium and chloride were salt as $\mathrm{NaCl}$, the mass ratio of chloride to sodium should be the same in ground water as in salt (about 1.54), although cation exchange can affect ion ratios. Because the mass ratio is greater than 1.54 for chloride to sodium, the data suggest sources of chloride other than salt. In southeastern Pennsylvania, both calcium chloride and sodium chloride salts are applied to roads in the winter months. None of the chloride concentrations in the groundwater samples exceeded the USEPA SMCL of $250 \mathrm{mg} / \mathrm{L}$ for chloride. The median concentration of chloride in water samples from the Wissahickon Schist is $8.3 \mathrm{mg} / \mathrm{L}$. 
Table 12. Summary of concentrations of major ions and radon-222 in ground water in the Big Elk Creek Basin, Pennsylvania and Maryland

[mg/L, milligrams per liter; $\mathrm{pCi} / \mathrm{L}$, picocuries per liter <, less than; --, insufficient data to compute median]

\begin{tabular}{|c|c|c|c|c|}
\hline \multirow{2}{*}{ Constituent } & \multirow{2}{*}{$\begin{array}{l}\text { Number } \\
\text { of wells } \\
\text { sampled }\end{array}$} & \multicolumn{3}{|c|}{ Concentrations (mg/L) } \\
\hline & & Minimum & Median & Maximum \\
\hline \multicolumn{5}{|l|}{ Total dissolved solids (mg/L) } \\
\hline Peters Creek Schist & 3 & 79 & -- & 263 \\
\hline Serpentinite & 3 & 230 & -- & 249 \\
\hline Wissahickon Schist & 38 & 33 & 100 & 231 \\
\hline Pelitic gneiss & 3 & 102 & -- & 599 \\
\hline \multicolumn{5}{|l|}{ Calcium (mg/L) } \\
\hline Peters Creek Schist & 3 & 2.9 & -- & 27.1 \\
\hline Serpentinite & 3 & 1.8 & -- & 4.6 \\
\hline Wissahickon Schist & 38 & 1.9 & 9.3 & 66.1 \\
\hline Pelitic gneiss & 3 & 13.3 & -- & 66.1 \\
\hline \multicolumn{5}{|l|}{ Chloride (mg/L) } \\
\hline Peters Creek Schist & 4 & 4.1 & -- & 150 \\
\hline Serpentinite & 3 & 4.9 & -- & 5.4 \\
\hline Wissahickon Schist & 47 & 1.8 & 8.3 & 130 \\
\hline Pelitic gneiss & 3 & 3.3 & -- & 218 \\
\hline \multicolumn{5}{|l|}{ Fluoride (mg/L) } \\
\hline Peters Creek Schist & 3 & $<.1$ & -- & .1 \\
\hline Serpentinite & 3 & $<.1$ & -- & $<.1$ \\
\hline Wissahickon Schist & 40 & $<.1$ & $<.1$ & .5 \\
\hline Pelitic gneiss & 3 & $<.1$ & -- & $<.1$ \\
\hline \multicolumn{5}{|l|}{ Magnesium (mg/L) } \\
\hline Peters Creek Schist & 3 & 1.5 & -- & 3.2 \\
\hline Serpentinite & 3 & 53 & -- & 59 \\
\hline Wissahickon Schist & 38 & .8 & 3.9 & 36.7 \\
\hline Pelitic gneiss & 3 & 2.2 & -- & 37.4 \\
\hline \multicolumn{5}{|l|}{ Potassium (mg/L) } \\
\hline Peters Creek Schist & 3 & .7 & -- & 1.8 \\
\hline Serpentinite & 3 & .1 & -- & .2 \\
\hline Wissahickon Schist & 37 & .4 & 1.7 & 3.3 \\
\hline Pelitic gneiss & 3 & 1 & -- & 2.1 \\
\hline \multicolumn{5}{|l|}{ Radon-222 (pCi/L) } \\
\hline Peters Creek Schist & 2 & 4,300 & -- & 5,300 \\
\hline Serpentinite & 3 & 42 & -- & 392 \\
\hline Wissahickon Schist & 35 & 285 & 2,500 & 11,000 \\
\hline Pelitic gneiss & 3 & 528 & -- & 2,400 \\
\hline \multicolumn{5}{|l|}{ Silica (mg/L) } \\
\hline Peters Creek Schist & 3 & 12 & -- & 23.9 \\
\hline Serpentinite & 3 & 5.3 & -- & 46.8 \\
\hline Wissahickon Schist & 37 & 7.5 & 18 & 34 \\
\hline Pelitic gneiss & 3 & 28 & -- & 34 \\
\hline \multicolumn{5}{|l|}{ Sodium (mg/L) } \\
\hline Peters Creek Schist & 3 & 4.5 & -- & 5.8 \\
\hline Serpentinite & 3 & 1.5 & -- & 3.4 \\
\hline Wissahickon Schist & 38 & 2.5 & 6.7 & 33.3 \\
\hline Pelitic gneiss & 3 & 7.6 & -- & 38.8 \\
\hline \multicolumn{5}{|l|}{ Sulfate (mg/L) } \\
\hline Peters Creek Schist & 3 & 12 & -- & 23.9 \\
\hline Serpentinite & 3 & 3.5 & -- & 8.8 \\
\hline Wissahickon Schist & 45 & .1 & 4 & 21 \\
\hline Pelitic gneiss & 3 & 10.1 & & 20.3 \\
\hline
\end{tabular}


Table 13. U.S. Environmental Protection Agency maximum contaminant levels and secondary maximum contaminant levels for selected constituents in drinking water [From U.S. Environmental Protection Agency, 1991; 1992a; and 1999; concentrations in micrograms per liter except as indicated; $\mathrm{mg} / \mathrm{L}$, milligrams per liter; pCi/L, picocuries per liter; --, no set limit]

\begin{tabular}{|c|c|c|}
\hline Constituent & $\begin{array}{c}\text { Maximum } \\
\text { contaminant } \\
\text { level }\end{array}$ & $\begin{array}{c}\text { Secondary } \\
\text { maximum } \\
\text { contaminant level }\end{array}$ \\
\hline \multicolumn{3}{|l|}{ Inorganic } \\
\hline Arsenic & 50 & -- \\
\hline Barium (mg/L) & 1 & -- \\
\hline Cadmium & 5 & -- \\
\hline Chloride (mg/L) & -- & 250 \\
\hline Chromium & 100 & -- \\
\hline Copper & -- & 1,000 \\
\hline Fluoride & 4 & 2 \\
\hline Iron & -- & 300 \\
\hline Lead & ${ }^{1} 15$ & -- \\
\hline Manganese & -- & 50 \\
\hline Mercury & 2 & -- \\
\hline Nitrate as nitrogen (mg/L) & 10 & -- \\
\hline Nitrite as nitrogen (mg/L) & 1 & -- \\
\hline Selenium & 50 & -- \\
\hline Silver & -- & 100 \\
\hline Sulfate (mg/L) & -- & 250 \\
\hline Total dissolved solids (mg/L) & -- & 500 \\
\hline Zinc (mg/L) & -- & 5 \\
\hline \multicolumn{3}{|l|}{ Organic } \\
\hline Benzene & 5 & -- \\
\hline Carbon tetrachloride & 5 & -- \\
\hline 1,2-dichloroethane & 5 & -- \\
\hline 1,1-dichloroethylene & 7 & -- \\
\hline 1,2-dichloropropane & 5 & -- \\
\hline Ethylbenzene & 700 & -- \\
\hline PCB & .5 & -- \\
\hline Styrene & .1 & -- \\
\hline Tetrachloroethylenen (PCE) & 5 & -- \\
\hline Toluene & 1,000 & -- \\
\hline 1,1,1-trichloroethane (TCA) & 200 & -- \\
\hline Trichloroethylene (TCE) & 5 & -- \\
\hline Vinyl chloride & 2 & -- \\
\hline Xylenes & 10,000 & -- \\
\hline \multicolumn{3}{|l|}{ Pesticide } \\
\hline Alachlor & 2 & -- \\
\hline Atrazine & 3 & -- \\
\hline Chlordane & 2 & -- \\
\hline Endrin & .2 & -- \\
\hline Heptachlor & .4 & -- \\
\hline Heptachlor epoxide & .2 & -- \\
\hline Lindane & 4 & -- \\
\hline Methoxychlor & 100 & -- \\
\hline Toxaphene & 5 & -- \\
\hline $2,4-D$ & 100 & -- \\
\hline 2,4,5-TP (silvex) & 10 & -- \\
\hline \multicolumn{3}{|l|}{ Radionuclide } \\
\hline Radon-222, no indoor air program (pCi/L) & ${ }^{2} 300$ & -- \\
\hline Radon-222, with indoor air program (pCi/L) & ${ }^{2} 4,000$ & -- \\
\hline
\end{tabular}

${ }^{1}$ Action level.

2 Proposed. 


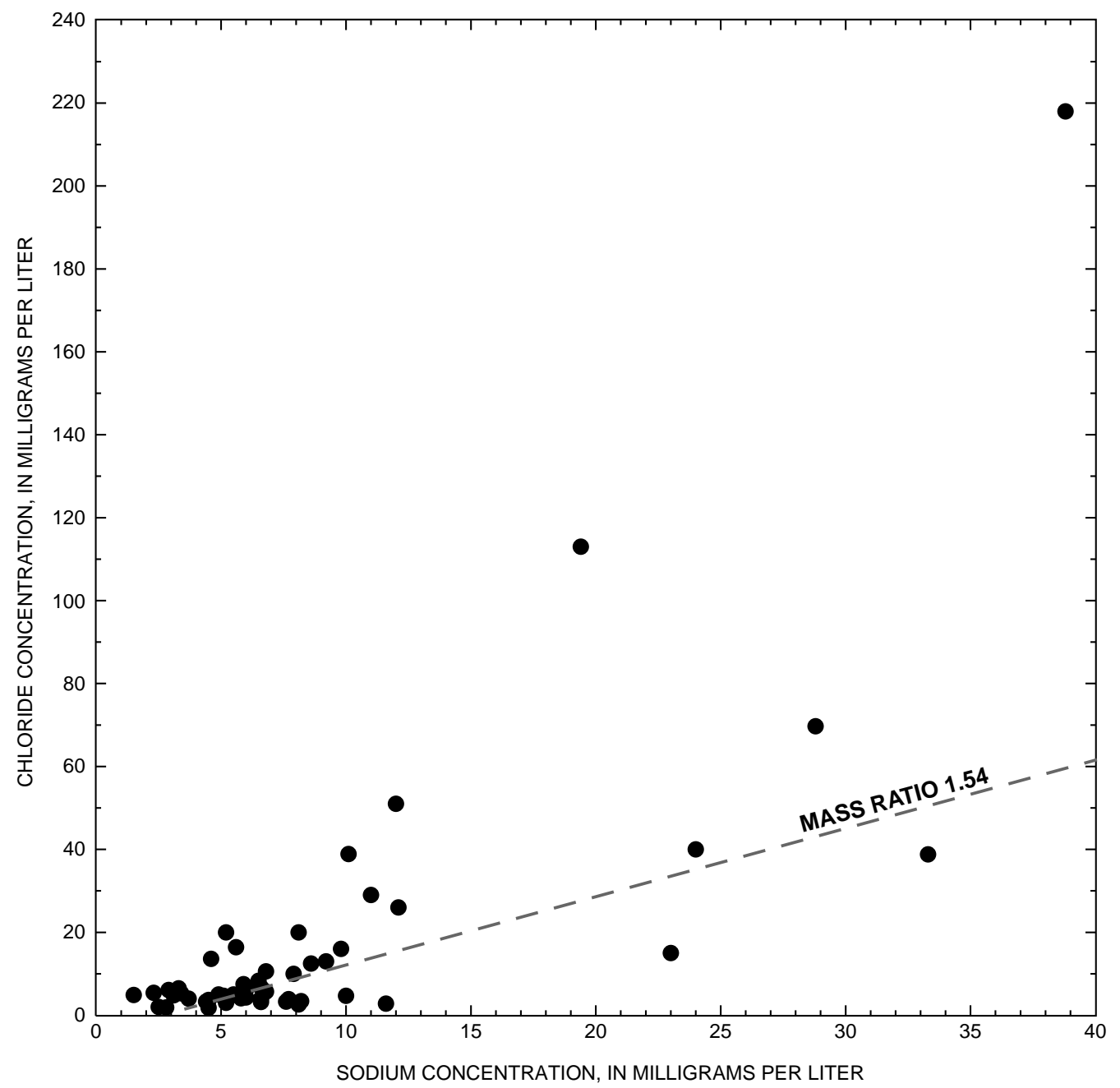

Figure 12. Relation between concentrations of sodium and chloride in ground water in the Big Elk Creek Basin, Pennsylvania and Maryland.

Sulfate $\left(\mathrm{SO}_{4}{ }^{-2}\right)$ is a common constituent of ground water derived from atmospheric precipitation and minerals. Sulfuric acid generated during coal combustion contributes to the acidity of rain in eastern Pennsylvania-the median concentration of sulfate in precipitation in Chester County is about 10 mg/L (Sloto, 1994, p. 57). Mineral sources of sulfur include metallic sulfides, such as pyrite $\left(\mathrm{FeS}_{2}\right)$. Sewage is another source of sulfate. Most sulfate in the ground water in the Big Elk Creek Basin probably is from natural mineral sources. The median concentration of sulfate in water samples from the Wissahickon Schist is $4 \mathrm{mg} / \mathrm{L}$. None of the sulfate concentrations in the ground-water samples exceeded the USEPA SMCL of $250 \mathrm{mg} / \mathrm{L}$ for sulfate. 
Waters commonly are characterized by the relative percentage of major ions in solution. A trilinear diagram for cations and anions (expressed in milliequivalents per liter), known as a Piper diagram (fig. 13), shows ground-water compositions (water types) that reflect aquifer mineralogy and chemical loads to ground water. According to Hem (1985, p. 166), a water in which no one cation or anion constitutes as much as 50 percent of the totals should be recognized as a mixed water type and identified by the names of all the important cations and anions. Ground water from the Wissa- hickon Schist and Peters Creek Schist is of a similar water type; ground water from the serpentinite is distinctly different. For the Wissahickon Schist and Peters Creek Schist, no cation is predominant; calcium, magnesium, and sodium are in nearly equal concentrations expressed in milliequivalents per liter. Bicarbonate is the dominant anion. Ground water from serpentinite is of the magnesium bicarbonate type; magnesium is the dominant cation, and bicarbonate is the dominant anion.

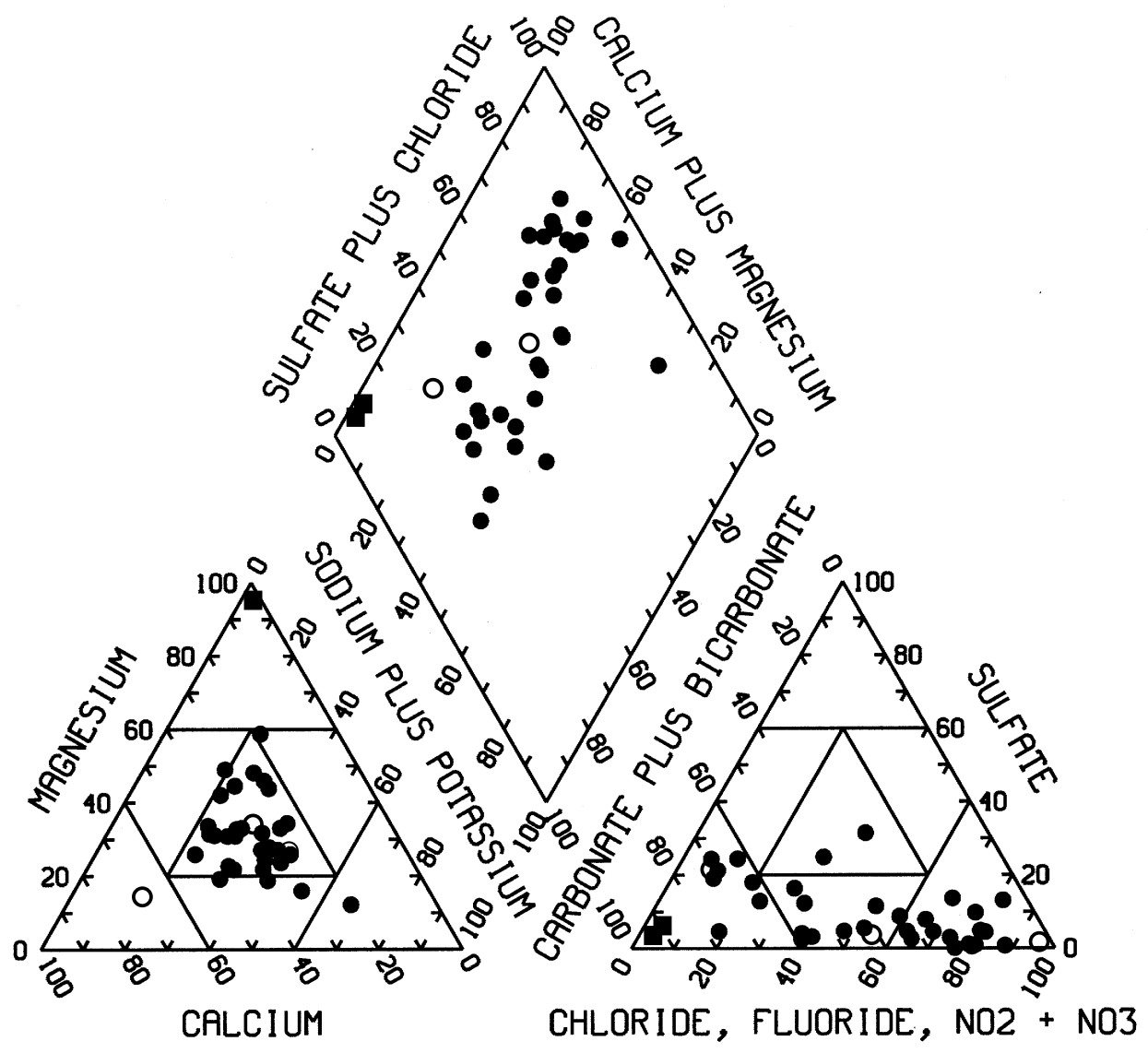

PERCENTAGE OF TOTAL MILLIEQUIVALENTS PER LITER

\section{EXPLANATION}

- WISSAHICKON SCHIST

O PETERS CREEK SCHIST

- SERPENTINITE

Figure 13. Relative concentrations of major ions in ground water in the Big Elk Creek Basin, Pennsylvania. 


\section{Nutrients}

Nutrients in ground water include nitrogen and phosphorus species, which are essential for plant and animal growth. Nitrogen is found in water principally as nitrate $\left(\mathrm{NO}_{3}\right)$, nitrite $\left(\mathrm{NO}_{2}\right)$, and ammonia $\left(\mathrm{NH}_{4}\right)$. Phosphorus is found in water principally as a form of the orthophosphate ion species. Nutrient concentrations above natural background levels indicate pollution resulting from human activities. Sources of nutrients in ground water include fertilizers, storm runoff, animal wastes, and effluent from septic systems. Concentrations of nutrients are summarized in table 14. Complete chemical analyses for nutrients are given in table 20 .

Some nitrate concentrations in table 14 were computed by subtracting the concentration of nitrite from the concentration of nitrate plus nitrite. When nitrite was below the detection limit, zero was used in the computation. The median concentration of nitrate in water samples from the Wissahickon
Schist is $3.6 \mathrm{mg} / \mathrm{L}$ (table 14). Of 60 water samples from wells in the Big Elk Creek Basin, concentrations of nitrate exceed the USEPA MCL of $10 \mathrm{mg} / \mathrm{L}$ nitrate as nitrogen in water from 6 wells (10 percent of wells sampled). All of these wells are in the Wissahickon Schist. The maximum concentration was $36 \mathrm{mg} / \mathrm{L}$.

Nitrite, ammonia, and phosphorus species generally are present in concentrations less than $0.10 \mathrm{mg} / \mathrm{L}$; median concentrations of these constituents for the Wissahickon Schist are equal to or less than $0.02 \mathrm{mg} / \mathrm{L}$ (table 14). Concentrations of ammonia or phosphate above background concentrations in ground water can indicate contamination, as can elevated concentrations of nitrate. Ammonium $\left(\mathrm{NH}_{4}^{+}\right)$is the dominant form of ammonia $\left(\mathrm{NH}_{3}\right)$ in most natural waters. Ammonium commonly is oxidized to form nitrate and rarely is detected in uncontaminated ground water in concentrations greater than about $0.5 \mathrm{mg} / \mathrm{L}$.

Table 14. Summary of concentrations of nutrients in ground water in the Big Elk Creek Basin, Pennsylvania and Maryland

[All concentrations are given in milligrams per liter; <, less than; --, insufficient data to compute median]

\begin{tabular}{|c|c|c|c|c|}
\hline \multirow{2}{*}{ Constituent } & \multirow{2}{*}{$\begin{array}{l}\text { Number } \\
\text { of wells } \\
\text { sampled }\end{array}$} & \multicolumn{3}{|c|}{ Concentration } \\
\hline & & Minimum & Median & Maximum \\
\hline \multicolumn{5}{|l|}{ Nitrate as nitrogen } \\
\hline Peters Creek Schist & 3 & $<0.050$ & -- & 4.1 \\
\hline Serpentinite & 3 & .050 & -- & .392 \\
\hline Wissahickon Schist & 48 & $<.050$ & 3.6 & 36 \\
\hline Pelitic gneiss & 3 & $<.050$ & -- & 2.31 \\
\hline \multicolumn{5}{|l|}{ Nitrite as nitrogen } \\
\hline Peters Creek Schist & 4 & $<.010$ & -- & $<.010$ \\
\hline Serpentinite & 3 & $<.010$ & -- & .013 \\
\hline Wissahickon Schist & 43 & $<.010$ & $<.010$ & .012 \\
\hline Pelitic gneiss & 3 & $<.010$ & -- & $<.010$ \\
\hline \multicolumn{5}{|l|}{ Ammonia as nitrogen } \\
\hline Peters Creek Schist & 3 & $<.010$ & -- & .022 \\
\hline Serpentinite & 3 & .020 & -- & .052 \\
\hline Wissahickon Schist & 43 & $<.010$ & .010 & .080 \\
\hline Pelitic gneiss & 3 & $<.020$ & -- & .024 \\
\hline \multicolumn{5}{|l|}{ Phosphorus } \\
\hline Peters Creek Schist & 2 & $<.010$ & -- & .040 \\
\hline Serpentinite & 2 & $<.010$ & -- & -- \\
\hline Wissahickon Schist & 21 & $<.010$ & $<.050$ & .105 \\
\hline Pelitic gneiss & 3 & $<.050$ & -- & $<.050$ \\
\hline \multicolumn{5}{|c|}{ Orthophosphate as phosphorus } \\
\hline Peters Creek Schist & 3 & $<.010$ & -- & .040 \\
\hline Serpentinite & 3 & .010 & -- & .028 \\
\hline Wissahickon Schist & 40 & $<.010$ & .020 & .090 \\
\hline Pelitic gneiss & 3 & .015 & -- & .028 \\
\hline
\end{tabular}




\section{Metals and Trace Constituents}

Metals, such as iron, lead, and manganese, and trace constituents, such as arsenic, typically are present in low concentrations (less than $1 \mathrm{mg} / \mathrm{L}$ ) in water samples from wells in the Big Elk Creek Basin. Other constituents, such as antimony and silver, may be present but commonly are not analyzed. If present, concentrations generally are below the detection limit of analytical instruments or procedures. The USEPA has established MCL's and SMCL's for some of these constituents in drinking water (table 13).

Most metals and trace constituents in natural ground water are leached from the soil or dissolved from the underlying bedrock in minute quantities by circulating ground water. Some are present in precipitation. Many metals are soluble in acidic water. Copper, lead, and zinc in tap water may be leached from household plumbing systems by acidic ground water. Copper leached from pipes commonly is deposited as blue or green precipitates on plumbing fixtures.

Data on the concentration of metals and other trace constituents in ground water are summarized in table 15. Except for iron and manganese, these constituents do not pose a water-quality problem in the Big Elk Creek Basin. The median concentrations of constituents in table 15 represent natural background concentrations. Data for trace constituents are difficult to evaluate statistically because concentrations commonly are below detection limits. In addition, a constituent may have several detection limits. The action level for lead (table 13), as defined by the USEPA, means a public water purveyor must take corrective action if the concentration of lead is above $15 \mu \mathrm{g} / \mathrm{L}$ in more than 10 percent of tap-water samples collected during any monitoring period. The USEPA SMCL's were exceeded only for iron and manganese.

Table 15. Summary of concentrations of dissolved metals and trace constituents in ground water in the Big Elk Creek Basin, Pennsylvania and Maryland

[All concentrations are given in micrograms per liter; <, less than; --, insufficient data to compute median]

\begin{tabular}{|c|c|c|c|c|c|}
\hline \multirow{2}{*}{ Constituent } & \multirow{2}{*}{$\begin{array}{c}\text { Number of } \\
\text { samples }\end{array}$} & \multirow{2}{*}{$\begin{array}{c}\text { Number of } \\
\text { samples above } \\
\text { detection level }\end{array}$} & \multicolumn{3}{|c|}{ Concentration } \\
\hline & & & Minimum & Median & Maximum \\
\hline Aluminum & 12 & 6 & $<1$ & -- & 50 \\
\hline Antimony & 3 & 3 & $<1$ & -- & -- \\
\hline Arsenic & 41 & 7 & $<1$ & $<1$ & 2 \\
\hline Barium & 36 & 29 & 4 & -- & 208 \\
\hline Boron & 12 & 2 & $<20$ & $<20$ & 80 \\
\hline Cadmium & 46 & 3 & $<.1$ & -- & 8 \\
\hline Chromium & 46 & 4 & $<1$ & -- & 14.3 \\
\hline Cobalt & 35 & 0 & $<1$ & -- & -- \\
\hline Copper & 42 & 18 & $<1$ & -- & 380 \\
\hline Iron & 60 & 42 & $<1$ & 20 & 3,400 \\
\hline Lead & 46 & 13 & $<1$ & -- & 10 \\
\hline Lithium & 33 & 18 & $<1$ & -- & 12.7 \\
\hline Manganese & 49 & 41 & 2 & 20 & 330 \\
\hline Mercury & 20 & 0 & $<.1$ & -- & -- \\
\hline Nickel & 41 & 12 & $<1$ & -- & 39 \\
\hline Selenium & 11 & 4 & $<1$ & $<1$ & 3 \\
\hline Silver & 35 & 0 & $<1$ & -- & -- \\
\hline Zinc & 43 & 22 & 1 & $<20$ & 1,300 \\
\hline
\end{tabular}


Elevated concentrations of iron and manganese in water may impart a bitter taste and stain laundry and plumbing fixtures. The USEPA SMCL's are set for aesthetic rather than health reasons. Sources of iron in ground water include minerals in the bedrock, such as pyroxenes, amphiboles, hematite, magnetite, and pyrite, and corrosion of iron well casings. Bacterial activity may elevate iron concentrations. Sources of manganese in ground water include minerals in the bedrock, such as biotite and hornblende. Of the water samples analyzed, 9 of 59 samples (15 percent) analyzed for iron and 16 of 56 samples (29 percent) analyzed for manganese exceeded the USEPA SMCL. Water samples exceeding the $300 \mu \mathrm{g} / \mathrm{L}$ USEPA SMCL for iron were from six wells in Wissahickon Schist, one well in Peters Creek Schist, one well in pegmatite, and one well in pelitic gneiss. Water samples exceeding the $50 \mu \mathrm{g} / \mathrm{L}$ USEPA SMCL for manganese were from 13 wells in Wissahickon Schist, 1 well in Peters Creek Schist, 1 well in pegmatite, and 1 well in pelitic gneiss. Water from three wells in Wissahickon Schist $(\mathrm{CH}-1778$, $\mathrm{CH}-3316$, and $\mathrm{CH}-5430)$, one well in Peters Creek Schist $(\mathrm{CH}-5425)$, one well in pegmatite (CH-5450), and one well in pelitic gneiss (CE Ae 8) had concentrations of both iron and manganese that exceeded the USEPA SMCL's (table 20).

\section{Radon-222}

Radon-222 is a naturally occurring, colorless, odorless, radioactive gas that is soluble in water. It is produced through the radioactive decay of uranium and radium, which is present naturally in soil and in minerals in bedrock. The rate of radon's radioactive decay is defined by its half-life, which is the time required for one half of the amount of radon present to break down to form other elements. Radon has a short half-life of 3.8 days. The Surgeon General of the United States has recognized exposure to radon gas as being second only to cigarette smoking as a cause of lung cancer (U.S. Environmental Protection Agency, 1992b). Radon gas can cause lung cancer if inhaled because its decay products can accumulate in the lungs and damage lung tissue. Radon moves from its source in rocks and soils through voids and fractures. It can enter buildings as a gas through foundation cracks, or it can dissolve in ground water and be carried to buildings through the use of water-supply wells. The USEPA has proposed an
MCL of $300 \mathrm{pCi} / \mathrm{L}$ for radon-222 in drinking water for water systems without an individual indoor air radon program and $4,000 \mathrm{pCi} / \mathrm{L}$ for water systems with an individual indoor air radon program (U.S. Environmental Protection Agency, 1999). Radon222 in the ground water of Chester County is discussed in detail by Senior (1998) and summarized by Sloto and Senior (1998).

Water samples from 44 wells were analyzed for radon-222 activity (table 12). The samples were collected from 35 wells in the Wissahickon Schist, 3 wells in serpentinite, 2 wells in the Peters Creek Schist, 3 wells in pelitic gneiss, and 1 well in pegmatite. Radon-222 activity in ground water generally differs among rock types and can vary considerably within the same geologic formation.

The median activity for all formations sampled in the Big Elk Creek Basin was 2,400 pCi/L. Water from 41 of 44 wells sampled (94 percent) in the basin exceeded $300 \mathrm{pCi} / \mathrm{L}$, and water from 5 of 44 wells sampled ( 25 percent) exceeded $4,000 \mathrm{pCi} / \mathrm{L}$. The median activity for water from 35 wells sampled in the Wissahickon Schist was $2,500 \mathrm{pCi} / \mathrm{L}$ (table 12). Activities of radon-222 in water samples from the Wissahickon Schist ranged over three orders of magnitude-from 285 to $11,000 \mathrm{pCi} / \mathrm{L}$. Radon-222 activities in water from one of three wells sampled in serpentinite (33 percent) exceeded $300 \mathrm{pCi} / \mathrm{L}$; the maximum activity was $392 \mathrm{pCi} / \mathrm{L}$. Serpentinite contains few radioactive minerals. Radon-222 activities in water from both wells sampled in the Peters Creek Schist exceeded 4,000 pCi/L. Of all the geologic units sampled in Chester County, ground water in the Peters Creek Schist has the highest median radon222 activity $(4,400 \mathrm{pCi} / \mathrm{L})$, and ground water in serpentinite has the lowest median radon-222 activity (150 pCi/L) (Sloto and Senior, 1998).

\section{Organic Compounds}

One of the most serious consequences of urbanization is the introduction of human-made organic compounds into the subsurface environment. Some of these compounds have been entering the ground-water system for decades, but awareness of their presence in drinking-water supplies did not begin until the mid-1970's, when analytical techniques became available to detect their presence. The USEPA has set MCL's for some organic compounds in drinking water (table 13). 


\section{Volatile Organic Compounds}

Volatile organic compounds (VOC's) are used extensively in industrial, commercial, and household applications. Their presence in ground water presents a serious problem for public water suppliers, industries, and domestic well owners that rely on ground water. Many VOC's are confirmed or suspected human or animal carcinogens. VOC's generally enter the ground-water system by spills, leakage from storage tanks, discharge from septic systems, and from lagoons and disposal sites. Once in the ground-water system, VOC's are difficult to remove, and treatment generally is expensive.

Water samples analyzed for VOC's are summarized in table 16, which also includes total phenols, total polychlorinated biphenyls (PCB), and total polychlorinated napthalenes (PCN). The choice of wells for sampling generally was biased toward wells where the potential existed for the presence of VOC's in ground water, such as near landfills and industrial sites. Out of 43 compounds analyzed, only 4 were detected-chloroform, total phenols, tert-butyl methyl ether (MTBE), and toluene. None of the samples exceeded USEPA MCL's. This is different from Chester County as a whole, where VOC's were detected in 32 percent of wells sampled, and the most commonly detected compounds in decreasing order were trichloroethylene (TCE), 1,1,1-trichloroethane (TCA), and 1,2-transdichlorethylene (Sloto, 1994, p. 70-71).

\section{Pesticides}

Pesticides are used widely in the Big Elk Creek Basin. Pesticides are divided into insecticides and herbicides on the basis of their use. Insecticides are used in agricultural areas to control crop-damaging insects and in residential areas to control household and garden insects. Herbicides are used to control weeds that compete with crops in agricultural areas and home gardens. They also are used to control broad-leaf weeds on lawns and turf and to defoliate utility, railroad, and highway rights-of-way. For this study, water samples were collected from 20 wells and analyzed for pesticides. An additional 20 wells in the Big Elk Creek Basin were sampled for pesticides prior to this study. Not all wells were sampled for the same pesticides. A summary of pesticide data is presented in table 17. Complete analyses are presented in table 21.
The most commonly detected pesticides in the Big Elk Creek Basin are deethyl atrazine (71 percent of sampled wells), atrazine (35 percent of sampled wells), metolachlor (32 percent of sampled wells), carbaryl (19 percent of sampled wells), picloram (14 percent of sampled wells), simazine (13 percent of sampled wells), and carbofuran (11 percent of sampled wells). Most concentrations are extremely low and are in the parts per trillion range (table 17). A concentration of $0.003 \mu \mathrm{g} / \mathrm{L}$ is equivalent to 3 parts pesticide per trillion $(1,000,000,000,000)$ parts water. Pesticide concentrations detected did not exceed USEPA MCL's (table 13). Only pesticides detected in water samples are discussed below.

Atmospheric deposition may be the source of some pesticides in ground water. The atmosphere is now recognized as a major pathway by which pesticides can be transported and deposited in areas sometimes removed from their source. Pesticides have been found in both rain and air in all parts of the United States sampled by the USGS. The most commonly detected pesticides in rain in decreasing order are atrazine, alachlor, lindane, alpha- $\mathrm{HCH}$, methoxychlor, DDT, deethyl atrazine, dieldrin, and simazine. The most commonly detected pesticides in the air in decreasing order are DDT, methidathion, lindane, alpha- $\mathrm{HCH}$, diazinon, heptachlor, malathion, and dieldrin (U.S. Geological Survey, 1995).

Atrazine, cyanazine, and simazine belong to a class of compounds known as triazine herbicides. Deethyl atrazine is a major degradation product of atrazine. The triazine herbicides are used mainly for preemergence applications on corn, soybeans, hay, and other crops for control of grassy and broadleaf weeds. Atrazine was detected in water from 12 of 34 wells sampled (35 percent), and deethyl atrazine was detected in water from 22 of 31 wells sampled (71 percent). In Chester County, atrazine commonly is used to control weeds in corn, soybeans, and hay crops. In 1997, atrazine was the most heavily used herbicide; an estimated 75-82 million pounds were applied in the United States (Aspelin and Grube, 1999). Effective in 1993, its use for non-crop vegetation in fallow and noncrop land was eliminated by the USEPA. Microbial activity possibly accounts for significant degradation of atrazine in soil (U.S. Environmental Protection Agency, 2001). 
Table 16. Volatile organic compounds detected in ground water in the Big Elk Creek Basin, Pennsylvania

[Concentrations given in micrograms per liter; --, concentration below detection limit]

\begin{tabular}{|c|c|c|c|}
\hline Compound & $\begin{array}{l}\text { Number of } \\
\text { wells } \\
\text { sampled }\end{array}$ & $\begin{array}{l}\text { Number of wells with } \\
\text { concentration above } \\
\text { detection limit }\end{array}$ & $\begin{array}{c}\text { Maximum } \\
\text { concentration }\end{array}$ \\
\hline Benzene & 14 & 0 & -- \\
\hline Bromodichloromethane & 14 & 0 & -- \\
\hline Bromoform & 14 & 0 & -- \\
\hline Carbon tetrachloride & 14 & 0 & -- \\
\hline Chlorobenzene & 14 & 0 & -- \\
\hline Chloroethane & 11 & 0 & -- \\
\hline 2-Chloroethyl vinyl ether & 11 & 0 & -- \\
\hline Chloroform & 14 & 1 & 0.2 \\
\hline Dibromochloromethane & 14 & 0 & -- \\
\hline 1,2-Dibromoethylene & 2 & 0 & -- \\
\hline 1,2-Dibromomethane & 4 & 0 & -- \\
\hline 1,2-Dichlorobenzene & 9 & 0 & -- \\
\hline 1,3-Dichlorobenzene & 9 & 0 & -- \\
\hline 1,4-Dichlorobenzene & 9 & 0 & -- \\
\hline Dichlorodifluoromethane & 14 & 0 & -- \\
\hline 1,1-Dichloroethane & 14 & 0 & -- \\
\hline 1,2-Dichloroethane & 14 & 0 & -- \\
\hline 1,1-Dichloroethylene & 14 & 0 & -- \\
\hline cis-1,2,-Dichloroethylene & 3 & 0 & -- \\
\hline trans-1,2,-Dichloroethylene & 14 & 0 & -- \\
\hline 1,2-Dichloropropane & 14 & 0 & -- \\
\hline Dichloropropene & 11 & 0 & -- \\
\hline cis-1,3-Dichloropropene & 5 & 0 & -- \\
\hline trans-1,3-Dichloropropene & 5 & 0 & -- \\
\hline Ethylbenzene & 14 & 0 & -- \\
\hline Methyl bromide & 11 & 0 & -- \\
\hline Methylchloride & 5 & 0 & -- \\
\hline Methylene chloride & 14 & 0 & -- \\
\hline Phenols, total & 10 & 4 & 2 \\
\hline Polychlorinated napthalenes, total & 10 & 0 & -- \\
\hline Polychlorinated biphenyls, total & 10 & 0 & -- \\
\hline Styrene & 8 & 0 & -- \\
\hline 1,1,2,2-Tetrachloroethane & 11 & 0 & -- \\
\hline tert-Butyl methyl ether (MTBE) & 3 & 1 & .1 \\
\hline Tetrachloroethylene (PCE) & 14 & 0 & -- \\
\hline Toluene & 14 & 1 & .11 \\
\hline 1,1,1-Trichloroethane (TCA) & 14 & 0 & -- \\
\hline 1,1,2-Trichloroethane & 11 & 0 & -- \\
\hline Trichloroethylene (TCE) & 14 & 0 & -- \\
\hline Trichlorofluoromethane & 14 & 0 & -- \\
\hline 1,1,2-Trichlorofluoromethane (Freon 113) & 3 & 0 & -- \\
\hline Vinyl chloride & 14 & 0 & -- \\
\hline Xylene & 7 & 0 & -- \\
\hline
\end{tabular}


Table 17. Pesticides detected in ground water in the Big Elk Creek Basin, Pennsylvania and Maryland [All concentrations are given in micrograms per liter; <, less than; --, no data; $\mathrm{E}$, concentration is below the reporting limit and is estimated]

\begin{tabular}{|c|c|c|c|c|}
\hline Compound & $\begin{array}{c}\text { Number of } \\
\text { wells sampled }\end{array}$ & $\begin{array}{l}\text { Number of wells } \\
\text { with concentration } \\
\text { above reporting limit }\end{array}$ & $\begin{array}{c}\text { Minimum } \\
\text { concentration }\end{array}$ & $\begin{array}{c}\text { Maximum } \\
\text { concentration }\end{array}$ \\
\hline Acetochlor & 26 & 0 & $<0.002$ & -- \\
\hline Alachlor & 34 & 1 & $<.002$ & 2.49 \\
\hline Aldrin & 16 & 0 & $<.01$ & -- \\
\hline Alpha BHC & 27 & 0 & $<.002$ & -- \\
\hline Ametryne & 8 & 0 & $<.05$ & -- \\
\hline Atrazine & 34 & 12 & $<.001$ & .209 \\
\hline Benfluralin & 27 & 0 & $<.002$ & -- \\
\hline Butylate & 27 & 0 & $<.002$ & -- \\
\hline Carbaryl & 27 & 5 & $<.003$ & $.015 \mathrm{E}$ \\
\hline Carbofuran & 27 & 3 & $<.003$ & $.073 \mathrm{E}$ \\
\hline Carbophenothion & 9 & 0 & $<.01$ & -- \\
\hline Chlordane & 16 & 0 & $<.1$ & -- \\
\hline Chlorpyrifos & 33 & 0 & $<.01$ & -- \\
\hline Cyanazine & 31 & 1 & $<.004$ & .007 \\
\hline DCPA & 27 & 0 & $<.002$ & -- \\
\hline DDD & 16 & 0 & $<.01$ & -- \\
\hline DDE & 37 & 0 & $<.006$ & -- \\
\hline DDT & 16 & 0 & $<.01$ & -- \\
\hline Deethyl atrazine & 31 & 22 & $<.002$ & .33 \\
\hline DEF & 6 & 0 & $<.1$ & -- \\
\hline Diazinon & 35 & 2 & $<.002$ & 57 \\
\hline Dicamba & 7 & 0 & $<.04$ & -- \\
\hline Dieldrin & 40 & 2 & $<.001$ & .056 \\
\hline Disulfoton & 33 & 0 & $<.017$ & -- \\
\hline Endosulfan & 16 & 0 & $<.01$ & -- \\
\hline Endrin & 16 & 0 & $<.01$ & -- \\
\hline EPTC & 27 & 0 & $<.002$ & -- \\
\hline Ethalfluralin & 27 & 0 & $<.004$ & -- \\
\hline Ethion & 9 & 1 & $<.01$ & .02 \\
\hline Ethoprop & 27 & 0 & $<.003$ & -- \\
\hline Fonofos & 32 & 0 & $<.01$ & -- \\
\hline Heptachlor & 16 & 0 & $<.01$ & -- \\
\hline Heptachlor epoxide & 16 & 0 & $<.01$ & -- \\
\hline Lindane & 40 & 2 & $<.004$ & .03 \\
\hline Linuron & 27 & 0 & $<.002$ & -- \\
\hline Malathion & 35 & 2 & $.002 \mathrm{E}$ & 25 \\
\hline Methoxychlor & 16 & 1 & $<.01$ & .09 \\
\hline Methyl azinphos & 27 & 0 & $<.001$ & -- \\
\hline Methyl parathion & 35 & 0 & $<.01$ & -- \\
\hline Metolachlor & 34 & 11 & $<.002$ & .1 \\
\hline Metribuzin & 32 & 0 & $<.004$ & -- \\
\hline Mirex & 16 & 0 & $<.01$ & -- \\
\hline Molinate & 27 & 0 & $<.004$ & -- \\
\hline
\end{tabular}


Table 17. Pesticides detected in ground water in the Big Elk Creek Basin, Pennsylvania and Maryland-Continued [All concentrations are given in micrograms per liter; <, less than; --, no data; $\mathrm{E}$, concentration is below the reporting limit and is estimated]

\begin{tabular}{|c|c|c|c|c|}
\hline Compound & $\begin{array}{c}\text { Number of } \\
\text { wells sampled }\end{array}$ & $\begin{array}{l}\text { Number of wells } \\
\text { with concentration } \\
\text { above reporting limit }\end{array}$ & $\begin{array}{c}\text { Minimum } \\
\text { concentration }\end{array}$ & $\begin{array}{c}\text { Maximum } \\
\text { concentration }\end{array}$ \\
\hline Napropamide & 27 & 0 & $<0.003$ & -- \\
\hline Parathion & 35 & 0 & $<.01$ & -- \\
\hline Pebulate & 27 & 0 & $<.004$ & -- \\
\hline Pendimethalin & 27 & 0 & $<.004$ & -- \\
\hline Permethrin & 27 & 0 & $<.005$ & -- \\
\hline Perthane & 16 & 0 & $<.1$ & -- \\
\hline Phorate & 33 & 0 & $<.002$ & -- \\
\hline Picloram & 7 & 1 & $<.05$ & 0.32 \\
\hline Prometone & 32 & 0 & $<.018$ & -- \\
\hline Prometryn & 8 & 0 & $<.1$ & -- \\
\hline Pronamide & 27 & 0 & $<.003$ & -- \\
\hline Propachlor & 27 & 0 & $<.007$ & -- \\
\hline Propanil & 27 & 0 & $<.004$ & -- \\
\hline Propargite & 27 & 0 & $<.013$ & -- \\
\hline Propazine & 8 & 0 & $<.05$ & -- \\
\hline Silvex & 7 & 0 & $<.02$ & -- \\
\hline Simazine & 40 & 5 & $.003 \mathrm{E}$ & .041 \\
\hline Tebuthiuron & 27 & 0 & $<.01$ & -- \\
\hline Terbacil & 27 & 1 & $<.007$ & .034 \\
\hline Terbufos & 27 & 0 & $<.013$ & -- \\
\hline Thiobencarb & 27 & 1 & $<.002$ & $.003 \mathrm{E}$ \\
\hline Toxaphene & 16 & 0 & $<.1$ & -- \\
\hline Triallate & 27 & 0 & $<.001$ & -- \\
\hline Trifluralin & 30 & 1 & $<.002$ & .001 \\
\hline 2,6-Diethylaniline & 26 & 0 & $<.003$ & -- \\
\hline $2,4,5-T$ & 7 & 0 & $<.04$ & -- \\
\hline 2,4-D & 7 & 0 & $<.04$ & -- \\
\hline 2,4-DP & 5 & 0 & $<.01$ & -- \\
\hline
\end{tabular}

Simazine was detected in water from 5 of 40 wells sampled ( 13 percent). Simazine is a preemergence herbicide used on a number of crops, as well as in noncrop areas. Simazine is used to control broad-leaved weeds and annual grasses in field corn; alfalfa, vegetable, and ornamental crops; turf grass; orchards; and vineyards. At higher application rates, it is used for nonselective weed control in industrial areas.

Cyanazine was detected in water from 1 of 31 wells sampled. Cyanazine is a widely used preand postemergent herbicide to control grasses and broadleaf weeds primarily on corn fields. Cyanazine is atrazine with cyanide attached to it. In 1997, cyanazine was the eighth most heavily applied her- bicide; an estimated 18-22 million pounds were applied in the United States (Aspelin and Grube, 1999). Cyanazine is classified by the USEPA as a restricted-use pesticide. In 1995, the USEPA announced it had reached an agreement with the manufacturer to phase out cyanazine for use in the United States. All sales and distribution were prohibited after December 31, 1999 (U.S. Environmental Protection Agency, 1995).

The amide class of pesticides includes alachlor and metolachlor. Metolachlor was detected in water from 11 of 34 wells sampled (32 percent), and alachlor was detected in water from 1 of 34 wells sampled. Metolachlor is a preemergence herbicide used to control some broadleaf and 
annual grassy weeds in field corn, soybeans, grain sorghum, highway right-of-ways, and woody ornamentals. In 1997, metolachlor was the second most heavily applied herbicide; an estimated 6369 million pounds were applied in the United States (Aspelin and Grube, 1999).

Alachlor is a pre- and postemergent herbicide used to control annual grasses and many broadleaved weeds mainly on corn and soybean fields, but it also is used in commercial nurseries. In 1997, cyanazine was the twelfth most heavily applied herbicide; an estimated 13-16 million pounds were applied in the United States (Aspelin and Grube, 1999). It is used widely in Chester County.

The carbamate class of insecticides includes carbaryl, carbofuran, and thiobencarb. Carbaryl was detected in water from 5 of 27 wells sampled (19 percent), carbofuran was detected in water from 3 of 27 wells sampled ( 11 percent), and thiobencarb was detected in water from 1 of 27 wells sampled. Carbaryl is a wide-spectrum insecticide that controls a range of chewing and sucking insects on more than 120 agricultural crops, as well as on poultry, livestock, and pets. Carbaryl also has been used to control earthworms in turf and grass. Carbofuran is a widespectrum pesticide that controls insects, mites, and nematodes on field, fruit, vegetable, and forest crops. Thiobencarb most commonly is used on rice crops, but it also is used to control grasses and broadleaf weeds in such crops as lettuce, celery, and endive.

Picloram was detected in water from one of seven wells sampled (14 percent). Picloram belongs to the pyridine family of compounds. It is a systemic herbicide used to control broad-leaved weeds, brush, and broadleaf trees on pasture, rights-of-way along roads and power lines, forestland, and some grains. It also is used to control plants on industrial facility sites.

The organochlorine class of compounds includes DDT, dieldrin, lindane, and methoxychlor. Organochlorine compounds were the first organic pesticides developed and have been in use since the 1940's. Organochlorine insecticides have low solubility in water, are persistent in the environment, and are strongly bioaccumulated by many organisms. The use of many organochlorine insecticides has been prohibited or restricted to limited uses by the USEPA. In Chester County, endrin, lindane, and methoxychlor are or have been used by mushroom growers.
Dieldrin was detected in water from 2 of 40 wells sampled (5 percent). Dieldrin is a highly persistent organochlorine compound that has low mobility in soil. It has been used as a contact insecticide to control soil pests, termites, and many other pests. Dieldrin also is a degradation product of the pesticide aldrin. Aldrin is converted rapidly to dieldrin under most environmental conditions. Dieldrin is more persistent in soils with a high organic matter content. Most uses for aldrin and dieldrin were banned in 1975; at present, these compounds are no longer produced in or imported into the United States. The use of dieldrin has been restricted by the USEPA to certified personnel for application below the ground surface or within structures to control termites.

Lindane was detected in water from 2 of 40 wells sampled (5 percent). Sloto (1994, p. 73) found lindane to be the most commonly detected organochlorine pesticide in Chester County. It generally is associated with the mushroom industry. Lindane is an insecticide fumigant used on a wide range of soil-dwelling and plant-eating insects. Most uses of lindane in agriculture and in the dairy industry have been cancelled by the USEPA. Lindane is no longer manufactured in the United States. Lindane presently is used primarily for lumber and seed treatment and in lotions, creams, and shampoos for the control of fleas, lice, and mites.

Methoxychlor was detected in water from 1 of 16 wells sampled. Methoxychlor is an analog of DDT. Methoxychlor is used as an insecticide against flies, mosquitoes, cockroaches, chiggers, and a wide variety of other insects. It is used on agricultural crops, livestock, animal feed, grain storage, home gardens, and on pets. Methoxychlor is registered for use on fruits, vegetables, forage crops, and shade trees. It also is registered for veterinary use to kill parasites on dairy and beef cattle.

Organophosphorus insecticides have been used as substitutes for the banned organochlorine insecticides because they are less persistent in the environment and more selective in their targets. The organophosphorus class of compounds includes diazinon, ethion, and malathion. Diazinon was detected in water from 2 of 35 wells sampled (6 percent). Diazinon, first marketed in 1948, is a non-systemic insecticide used on home gardens and farms to control a wide variety of sucking and leaf-eating insects. It is used on fruit trees, corn, tobacco, potatoes, and horticultural plants. It com- 
monly is used in Chester County for control of the European corn borer, lawn-damaging insects, and on trees and shrubs. Diazinon is an ingredient in pest strips, household ant and roach sprays, and pet flea and tick collars. Over 13 million pounds of diazinon are applied annually in the United States (U.S. Environmental Protection Agency, 2000a). On March 31, 2001, the USEPA began a phase out of diazinon because of its potential health risks to children (U.S. Environmental Protection Agency, 2000b). The highest concentration of diazinon measured in a water sample from the Big Elk Creek Basin $(57 \mu \mathrm{g} / \mathrm{L})$ was from a well at a former mushroom-growing operation. Sloto (1994, p. 74) found diazinon to be the most commonly detected organophosphorus pesticide in Chester County; it was found in water samples from 13 percent of wells sampled.

Ethion was detected in water from one of nine wells sampled. Ethion is an insecticide used to kill aphids, mites, scales, leafhoppers, maggots, and foliar feeding larvae. It is used on a wide variety of food, fiber, and ornamental crops, including greenhouse crops, lawns, and turf.

Malathion was detected in water from 2 of 35 wells sampled ( 6 percent). Malathion is a nonsystemic, wide-spectrum insecticide introduced in 1950. Malathion is used for the control of sucking and chewing insects on fruits and vegetables and to control mosquitoes, flies, household insects, and animal and human parasites. The highest concentration of malathion measured in a water sample from the Big Elk Creek Basin $(25 \mu \mathrm{g} / \mathrm{L})$ was from a well at a former mushroom-growing operation.

Trifluralin was detected in water from 1 of 30 wells sampled. In 1997, trifluralin was the tenth most heavily applied herbicide; an estimated 21-25 million pounds were applied in the United States (Aspelin and Grube, 1999). Trifluralin belongs to the dinitroaniline class of compounds. It is a selective, preemergence herbicide used to control many annual grasses and broadleaf weeds on a wide variety of crops including alfalfa, barley, corn, soybeans, and wheat. It also is used on vegetable crops and in orchards.
Terbacil was detected in water from 1 of 27 wells sampled. Terbacil belongs to the uracil class of compounds. It is a selective herbicide used for control of annual grasses, broad-leaved weeds, and some perennial weeds in alfalfa and fruit trees. It is sprayed on soil surfaces preferably just before, or during, the period of active weed growth.

\section{SUMMARY}

The 79.4-mi ${ }^{2}$ Big Elk Creek study area extends from the headwaters in Chester County, Pa., downstream to the USGS streamflow-measurement station on Big Elk Creek at Elk Mills, Md., (52.6 mi²), and an inactive USGS streamflow-measurement station on Little Elk Creek at Childs, Md. $\left(26.8 \mathrm{mi}^{2}\right)$. Little Elk Creek is a tributary to Big Elk Creek.

The Big Elk Creek Basin in the study area is in the Piedmont Physiographic Province and is underlain almost entirely by crystalline rocks. Most of the basin in Pennsylvania is underlain by Wissahickon Schist. In Maryland, the rocks formerly assigned to the Wissahickon Schist in the Big Elk Creek Basin have been subdivided into an informally named pelitic and metagraywacke metasedimentary lithofacies. All the crystalline-rock geologic units in the Big Elk Creek Basin are bedrock aquifers. The ground-water-flow system in crystalline rock is local with streams acting as drains. Flow paths are short, and ground water flows from areas of higher elevation to adjacent streams. The hydrologic system generally is under unconfined (watertable) conditions. Ground water flows through a network of interconnected secondary openings that comprise the water-bearing zones that provide water to wells. The larger, more numerous, and more interconnected the openings, the greater the yield of a well.

Wells in the Wissahickon Schist in the Big Elk Creek Basin had a mean of 3.56 water-bearing zones per $100 \mathrm{ft}$ of uncased borehole. The frequency of occurrence of water-bearing zones generally decreases with depth. Yields of wells in the Wissahickon Schist range from 5 to $200 \mathrm{gal} / \mathrm{min}$; the median yield is $15 \mathrm{gal} / \mathrm{min}$. The specific capacity of wells in the Wissahickon Schist ranges from 0.03 to $15(\mathrm{gal} / \mathrm{min}) / \mathrm{ft}$; the median specific capacity is $0.4(\mathrm{gal} / \mathrm{min}) / \mathrm{ft}$. 
Ground-water levels generally rise during the late fall, winter, and early spring when groundwater and soil-moisture evapotranspiration are at a minimum and recharge is at a maximum. Water levels generally decline during the late spring, summer, and early fall when ground-water evapotranspiration and soil-moisture evapotranspiration are at a maximum, and recharge is at a minimum. The range in water-level fluctuation for 1998-99 was up to $12.55 \mathrm{ft}$. Water levels generally are closest to land surface in valleys near streams (discharge areas) and deepest below land surface on hilltops (recharge areas).

Ground water discharged to streams provides more than half of streamflow. Streamflow is composed of base flow and surface runoff. Base flow is ground water discharged to streams. Streamflow hydrographs for Big Elk Creek and Little Elk Creek for their period of record were separated into baseflow and surface-runoff components. The median base flow for Big Elk Creek is representative of a long-term average. In the Big Elk Creek Basin, the median annual ground-water discharge to the stream (base flow) for 1933-99 was 10.79 in. or $0.518(\mathrm{Mgal} / \mathrm{d}) / \mathrm{mi}^{2}$, which was 63 percent of the median annual streamflow. The median annual ground-water discharge to streams ranged from 5.32 in. or $0.255(\mathrm{Mgal} / \mathrm{d}) / \mathrm{mi}^{2}$ in 1966 to $17.98 \mathrm{in}$. or $0.863(\mathrm{Mgal} / \mathrm{d}) / \mathrm{mi}^{2}$ in 1972 . Median annual surface runoff for 1933-99 was 6.22 in., which was 37 percent of the median annual streamflow.

Ground-water availability is defined and estimated in a number of ways. Estimated groundwater availability for the Big Elk Creek Basin ranges from 0.127 to $0.535(\mathrm{Mgal} / \mathrm{d}) / \mathrm{mi}^{2}$, depending on the method used. The optimal method is the one that best meets a set of socioeconomic and/or social and environmental objectives associated with the use of the water.

Water budgets were calculated for the Big Elk Creek Basin for 1998-99. The 1998-99 average streamflow was 15.38 in. The average change in ground-water storage was an increase of 1.32 in. The net ground-water exports from the basin averaged $0.03 \mathrm{in} / \mathrm{yr}$. Estimated average annual ET was 30.50 in. Recharge was estimated for the Big Elk Creek Basin for 1998-99. Estimated recharge was 11.22 in. [0.540 (Mgal/d)/mi $\left.{ }^{2}\right]$ in 1998, and $12.95 \mathrm{in.}\left[0.621(\mathrm{Mgal} / \mathrm{d}) / \mathrm{mi}^{2}\right]$ in 1999. Estimated average annual recharge for $1998-99$ was $12.12 \mathrm{in.}$ $\left[0.580(\mathrm{Mgal} / \mathrm{d}) / \mathrm{mi}^{2}\right]$; this is equal to a rate of $909 \mathrm{gal} / \mathrm{d}$ per acre.
For this study, water samples from 20 wells were collected for analysis for inorganic constituents and pesticides, and data were available from an additional 44 wells. Physical properties and chemical constituents determined in the field include $\mathrm{pH}$, specific conductance, hardness, alkalinity, temperature, and the concentration of dissolved oxygen. The median $\mathrm{pH}$ of water from wells in the Wissahickon Schist, the principal aquifer in the study area, is moderately acidic ( $\mathrm{pH}$ of 5.9). The median specific conductance of water from wells in the Wissahickon Schist is a relatively low $160 \mu \mathrm{S} / \mathrm{cm}$. The median alkalinity of water from wells in the Wissahickon Schist is $20 \mathrm{mg} / \mathrm{L}$. Water from wells in the Wissahickon Schist is soft; the median hardness is $38 \mathrm{mg} / \mathrm{L}$. The median temperature of ground-water samples from wells in the Wissahickon Schist is $13.6^{\circ} \mathrm{C}\left(56.5^{\circ} \mathrm{F}\right)$, which is near the mean annual air temperature. The median concentration of dissolved oxygen in ground water from the Wissahickon Schist was $7.5 \mathrm{mg} / \mathrm{L}$.

Major ions, in order of decreasing concentration, in the ground water of the Elk Creek Basin, based on median concentrations for the Wissahickon Schist, are silica, calcium, chloride, sodium, sulfate, magnesium, and potassium. Water from only 1 of 49 wells sampled ( 2 percent) in the Big Elk Creek Basin exceeded the USEPA SMCL of $500 \mathrm{mg} / \mathrm{L}$ for TDS. The median concentration of TDS in water samples from the Wissahickon Schist is $100 \mathrm{mg} / \mathrm{L}$. The median concentration of chloride in water samples from the Wissahickon Schist is $8.3 \mathrm{mg} / \mathrm{L}$. None of the chloride concentrations in the ground-water samples exceeded the USEPA SMCL of $250 \mathrm{mg} / \mathrm{L}$ for chloride. The median concentration of sulfate in water samples from the Wissahickon Schist is $4 \mathrm{mg} / \mathrm{L}$. None of the sulfate concentrations in the ground-water samples exceeded the USEPA SMCL of $250 \mathrm{mg} / \mathrm{L}$ for sulfate.

The median concentration of nitrate in water samples from the Wissahickon Schist is $3.6 \mathrm{mg} / \mathrm{L}$. Of 60 water samples from wells in the Big Elk Creek Basin, concentrations of nitrate exceed the USEPA MCL of $10 \mathrm{mg} / \mathrm{L}$ nitrate as nitrogen in water from 6 wells ( 10 percent of wells sampled), all of which are in the Wissahickon Schist. The maximum concentration was $36 \mathrm{mg} / \mathrm{L}$. Nitrite, ammonia, and phosphorus species generally are present in concentrations less than $0.10 \mathrm{mg} / \mathrm{L}$. 
Eight of 59 water samples (14 percent) analyzed for iron and 16 of 56 samples (29 percent) analyzed for manganese exceeded the USEPA SMCL's. Water samples exceeding the $300 \mu \mathrm{g} / \mathrm{L}$ USEPA SMCL for iron were from six wells in Wissahickon Schist, one well in Peters Creek Schist, one well in pegmatite, and one well in pelitic gneiss. Water samples exceeding the $50 \mu \mathrm{g} / \mathrm{L}$ USEPA SMCL for manganese were from 13 wells in the Wissahickon Schist, 1 well in the Peters Creek Schist, 1 well in pegmatite, and 1 well in pelitic gneiss.

Water from 41 of 44 wells in the Big Elk Creek Basin sampled (94 percent) for radon-222 exceeded $300 \mathrm{pCi} / \mathrm{L}$, the proposed USEPA MCL, and water from 5 of 44 wells sampled (25 percent) exceeded $4,000 \mathrm{pCi} / \mathrm{L}$, the proposed USEPA alternate $M C L$. The median activity for all formations was $2,400 \mathrm{pCi} / \mathrm{L}$. The median activity for water from 35 wells sampled in the Wissahickon Schist was $2,500 \mathrm{pCi} / \mathrm{L}$. Activities of radon-222 in water samples from the Wissahickon Schist ranged over three orders of magnitude-from 285 to $11,000 \mathrm{pCi} / \mathrm{L}$. Radon-222 activities in water from one of three wells sampled in serpentinite (33 percent) exceeded $300 \mathrm{pCi} / \mathrm{L}$; the maximum activity was $392 \mathrm{pCi} / \mathrm{L}$. Serpentinite contains few radioactive minerals. Radon-222 activities in water from both wells sampled in the Peters Creek Schist exceeded 4,000 pCi/L.

Out of 43 VOC compounds analyzed, only 4 were detected: chloroform, total phenols, tert-butyl methyl ether (MTBE), and toluene. None of the concentrations exceeded USEPA MCL's.

For this study, 20 wells were sampled for pesticides, and data were available for 20 additional wells sampled for pesticides. Not all wells were sampled for the same pesticides. The most commonly detected pesticides in the Big Elk Creek Basin are deethyl atrazine (71 percent of sampled wells), atrazine (35 percent of sampled wells), metolachlor (32 percent of sampled wells), carbaryl (19 percent of sampled wells), picloram (14 percent of sampled wells), simazine (13 percent of sampled wells), and carbofuran (11 percent of sampled wells). Most concentrations are extremely low and are in the parts per trillion range. Concentrations of pesticides detected did not exceed USEPA MCL's.

\section{REFERENCES CITED}

Aspelin, A.L., and Grube, A.H., 1999, Pesticide industry sales and usage 1996 and 1997 market estimates: U.S. Environmental Protection Agency Report 733-R-99-001, 46 p.

American Public Health Association, American Water Works Association, and Water Pollution Control Association, 1995, Standard methods for the examination of water and waste water (16th ed.): Washington, D.C., American Public Health Association [variously paginated].

Bascom, Florence, and Miller, B.L., 1920, Description of the Elkton and Wilmington quadrangles: U.S. Geological Survey Geologic Atlas, Folio 221, 22 p.

Bascom, Florence, and Stose, G.W., 1932, Description of the Coatesville and West Chester quadrangles: U.S. Geological Survey Geologic Atlas, Folio 223, 15 p.

Chester County, 1996, Landscapes - Managing change in Chester County 1996-2020 Comprehensive plan policy element: West Chester, Pa., 128 p.

Chester County Water Resources Authority, 2001, Chester County, Pennsylvania water resources compendium: West Chester, Pa. [variously paginated].

Delaware River Basin Commission, 1999, Ground water protected area regulations southeastern Pennsylvania: West Trenton, N.J., 41 p.

Dufor, C.N., and Becker, Edith, 1964, Public water supplies of the 100 largest cities in the United States, 1962: U.S. Geological Survey WaterSupply Paper 1812, $364 \mathrm{p}$.

Green Valleys Association, 2000, Sustainable watershed management for northern Chester County watersheds: Birchrunville, Pa. [variously paginated].

Hanan, B.B., and Sinha, A.K., 1989, Petrology and tectonic affinity of the Baltimore Mafic Complex, Maryland: Geological Society of America Special Paper 231, p. 1-18.

Hem, J.D., 1985, Study and interpretation of the chemical characteristics of natural water: U.S. Geological Survey Water-Supply Paper 2254, $263 \mathrm{p}$. 


\section{REFERENCES CITED-Continued}

Higgins, M.W., and Conant, L.B., 1986, Geologic map of Cecil County: Maryland Geological Survey, 1 pl., scale 1:62,500.

1990, The geology of Cecil County, Maryland: Maryland Geological Survey Bulletin 37, $183 \mathrm{p}$.

Lynch, J.A., Horner, K.S., Grimm, J.W., and Corbett, E.S.,1992, Atmospheric depositionSpatial and temporal variations in Pennsylvania-1991: University Park, Pa., Pennsylvania State University Environmental Resources Research Institute Report ER9207A, 274 p.

Lyttle, P.T., and Epstein, J.B., 1987, Geologic map of the Newark $1^{\circ} \times 2^{\circ}$ quadrangle, New Jersey, Pennsylvania, and New York: U.S. Geological Survey Miscellaneous Investigations Series Map I-1715, 2 pl., scale 1:250,000.

McGreevy, L.J., and Sloto, R.A., 1977, Groundwater resources of Chester County, Pennsylvania: U.S. Geological Survey WaterResources Investigations Report 77-67, 76 p.

Mohammad, Abdul, 2000, Altitude and configuration of the potentiometric surface in upper Elk Creek watershed, Chester County, Pennsylvania, January through June 1999: U.S. Geological Survey Open-File Report 99475, 1 pl., scale 1:24,000.

2001, Altitude and configuration of the potentiometric surface in lower Elk Creek watershed, Chester County, Pennsylvania, March through September 2000:

U.S. Geological Survey Open-File Report 01-329, 1 pl., scale 1:24,000.

National Oceanic and Atmospheric Administration, 2002, Monthly station normals of temperature, precipitation, and heating and cooling degree days 1971-2000: National Oceanic and Atmospheric Administration Climatography of the United States No. 81, 9 p.

Nutter, L.J., and Otton, E.G., 1969, Ground-water occurrence in the Maryland Piedmont: Maryland Geological Survey Report of Investigations 10, 56 p.
Olmsted, F.H., and Hely, A.G., 1962, Relation between ground water and surface water in Brandywine Creek Basin, Pennsylvania: U.S. Geological Survey Professional Paper 417-A, $21 \mathrm{p}$.

Otton, E.G., Wiley, R.E., McGregor, R.A., Achmad, G.J., Hiortdahl, S.N., and Gerhart, J.M., 1988, Water resources and estimated effects of ground-water development, Cecil County, Maryland: Maryland Geological Survey Bulletin 34, 133 p.

Overbeck, R.M., Slaughter, T.H., and Hulme, A.E., 1958, Water resources of Cecil, Kent, and Queen Annes Counties: Maryland Department of Geology, Mines, and Water Resources Bulletin 21, $478 \mathrm{p}$.

Schreffler, C.L., 1998, Low-flow statistics of selected streams in Chester County, Pennsylvania: U.S. Geological Survey WaterResources Investigations Report 98-4117, $43 \mathrm{p}$.

Senior, L.A., 1998, Radon-222 in the ground water of Chester County, Pennsylvania: U.S. Geological Survey Water-Resources Investigations Report 98-4169, 77 p.

Senior, L.A., Sloto, R.A., and Reif, A.G., 1997, Geohydrology and water quality, West Valley Creek Basin, Chester County, Pennsylvania: U.S. Geological Survey Water-Resources Investigations Report 94-4137, 160 p.

Sloto, R.A., 1987, Effect of urbanization on the water resources of eastern Chester County, Pennsylvania: U.S. Geological Survey WaterResources Investigations Report 87-4098, $131 \mathrm{p}$.

1989, Selected ground-water data, Chester County, Pennsylvania: U.S. Geological Survey Open-File Report 87-217, 198 p.

1991, Geohydrology and simulation of ground-water flow in the carbonate rocks of the Valley Creek Basin, eastern Chester County, Pennsylvania: U.S. Geological Survey WaterResources Investigations Report 89-4169, $60 \mathrm{p}$.

1994, Geology, hydrology, and ground-water quality of Chester County, Pennsylvania: Chester County Water Resources Authority Water-Resource Report 2, 127 p. 


\section{REFERENCES CITED-Continued}

Sloto, R.A., and Crouse, M.Y., 1996, HYSEPA computer program for hydrograph separation and analysis: U.S. Geological Survey WaterResources Investigations Report 96-4040, $46 \mathrm{p}$.

Sloto, R.A., and Senior, L.A., 1998, Radon in the ground water of Chester County, Pennsylvania: U.S. Geological Survey Fact Sheet 120-98, $4 \mathrm{p}$.

Todd, D.K., 1980, Ground water hydrology (2d ed.): New York, John Wiley and Sons, 535 p.

U.S. Environmental Protection Agency, 1991, Maximum contaminant level goals and national primary drinking water regulations for lead and copper; final rule: Federal Register, June 7, 1991 , p. 26,460-26,563.

1992a, Drinking water regulations, U.S. Code of Federal Regulations, Title 40, Part 141.61, Part 141.62, and Part 143.30; revised December, 1992: Washington, U.S. Environmental Protection Agency Office of Water, $12 \mathrm{p}$.

1992b, Consumers guide to radon reduction-How to reduce radon levels in your home: EPA Report 402-K92-003, $17 \mathrm{p}$.

1995, International pesticide notice cyanazine pesticide voluntarily canceled and uses phased out: accessed September 7, 2001, at URL www.epa.gov/oppfead1/17b/cyanazin.htm

1999, National primary drinking water regulation, Radon-222, proposed rule: Federal Register, v. 64, no. 211, November 2, 1999, p. 59,245-59,294. 2000a, Diazinon summary: accessed September 7, 2001, at URL www.epa.gov/pesticides/op/diazinon/summary. htm

2000b, EPA announces elimination of all indoor uses of widely-used pesticide diazinon: press release accessed September 7, 2001, at URL $h t t p: / / y o s e m i t e . e p a . g o v / o p a /$ admpress.nsf/b1ab9f485b098972852562e700 4dc686/c8cdc9ea7d5ff585852569ac0077bd31

2001, Technical fact sheet on atrazine: accessed September 7, 2001, at URL http://www.epa.gov/OGWDW/dwh/tsoc/atrazine.html

U.S. Geological Survey, 1995, Pesticides in the atmosphere: U.S. Geological Survey Fact Sheet 152-95, $4 \mathrm{p}$.

White, K.E., and Sloto, R.A., 1991, Base-flowfrequency characteristics of selected Pennsylvania streams: U.S. Geological Survey Water-Resources Investigations Report 90-4161, 66 p.

Willey, R.E., McGregor, R.A., deGrouchy, Joanne, and Tompkins, M.D., 1987, Hydrologic data for Cecil County, Maryland: Maryland Geological Survey Basic Data Report 16, 150 p.

Wood, W.W., 1981, Guidelines for collection and field analysis of ground-water samples for selected unstable constituents: U.S. Geological Survey Techniques of WaterResources Investigations, book 1, chap. D2, $24 \mathrm{p}$. 
Table 18. Records of selected wells, Big Elk Creek Basin, Pennsylvania and Maryland

Township or borough: Name refers to township unless noted as borough.

Driller license number: 0110, Brown Brothers Drilling; 0154, Leroy Myers; 0176, R. Walter Slaugh and Son; 1083, Kenneth L. Madron; 0248, Thomas G. Keyes; 0319, Myers Brothers Drilling; 0384, E.J. Myers and Sons; 1583, J. Ernest Brewer; 1715, Arthur A. Astle; 1878, Cooks Environmental Services; 1889, David Powell

Use of site: $U$, unused; $W$, withdrawal; $O$, observation well.

Use of water: $\mathrm{C}$, commercial; $\mathrm{H}$, domestic; I, industrial; P, public supply; $\mathrm{S}$, stock watering; T, institutional; $U$, unused.

Topographic setting: F, flat; H, hilltop; S, slope; V, valley.

Hydrogeologic unit codes: 300WSCK, Wissahickon Formation; 300PRCK, Peters Creek Schist; 000SPRN, serpentinite; 000PGMT, pegmatite; 300UFGB, gabbro and serpentinite at Gray's Hill; 300MGCK, metagraywacke

Altitude of land surface is estimated from topographic maps. Datum is sea level.

Water level is in feet below land surface. $F$ indicates flowing well.

Date water level measued is year, month, and date.

[--, no data; gal/min, gallons per minute; (gal/min)/ft, gallons per minute per foot of drawdown] 
Table 18. Records of selected wells, Big Elk Creek Basin, Pennsylvania and Maryland-Continued

\begin{tabular}{|c|c|c|c|c|c|c|c|c|c|}
\hline \multirow{2}{*}{$\begin{array}{c}\text { Well- } \\
\text { identification } \\
\text { number }\end{array}$} & \multicolumn{2}{|c|}{ Location } & \multirow{2}{*}{$\begin{array}{l}\text { Township or } \\
\text { borough }\end{array}$} & \multirow{2}{*}{$\begin{array}{l}\text { Driller } \\
\text { license } \\
\text { number }\end{array}$} & \multirow{2}{*}{$\begin{array}{c}\text { Year } \\
\text { drilled }\end{array}$} & \multicolumn{2}{|c|}{ Primary } & \multirow{2}{*}{$\begin{array}{c}\text { Elevation } \\
\text { of land } \\
\text { surface }\end{array}$} & \multirow{2}{*}{$\begin{array}{l}\text { Topo- } \\
\text { graphic } \\
\text { setting }\end{array}$} \\
\hline & $\begin{array}{l}\text { Latitude } \\
\text { (degrees) }\end{array}$ & $\begin{array}{l}\text { Longitude } \\
\text { (degrees) }\end{array}$ & & & & $\begin{array}{l}\text { Use of } \\
\text { site }\end{array}$ & $\begin{array}{l}\text { Use of } \\
\text { water }\end{array}$ & & \\
\hline $\mathrm{CH}-75$ & 394735 & 755809 & Oxford Borough & -- & 1938 & W & $P$ & 509 & $S$ \\
\hline $\mathrm{CH}-254$ & 394457 & 755816 & East Nottingham & 0384 & 1982 & 0 & $U$ & 517 & $\mathrm{~F}$ \\
\hline $\mathrm{CH}-525$ & 394829 & 755537 & Lower Oxford & -- & 1907 & $U$ & $\mathrm{~T}$ & 540 & $\mathrm{H}$ \\
\hline $\mathrm{CH}-526$ & 394745 & 755830 & Lower Oxford & 0390 & 1911 & W & $P$ & 590 & $\mathrm{H}$ \\
\hline $\mathrm{CH}-528$ & 394755 & 755820 & Lower Oxford & -- & -- & W & $P$ & 560 & S \\
\hline $\mathrm{CH}-1702$ & 394545 & 755912 & East Nottingham & 0110 & 1972 & W & $\mathrm{H}$ & 563 & $\mathrm{H}$ \\
\hline $\mathrm{CH}-1703$ & 394445 & 755800 & East Nottingham & 0176 & 1972 & W & $\mathrm{H}$ & 522 & S \\
\hline $\mathrm{CH}-1720$ & 394803 & 755638 & Lower Oxford & 0176 & 1969 & W & $\mathrm{H}$ & 444 & S \\
\hline $\mathrm{CH}-1722$ & 395115 & 755502 & Upper Oxford & 0110 & 1970 & W & $\mathrm{H}$ & 552 & S \\
\hline $\mathrm{CH}-1724$ & 395056 & 755640 & Upper Oxford & 0176 & 1971 & W & C & 606 & S \\
\hline $\mathrm{CH}-1735$ & 394628 & 755926 & East Nottingham & 0176 & 1967 & W & $\mathrm{H}$ & 540 & S \\
\hline $\mathrm{CH}-1737$ & 394752 & 755459 & Lower Oxford & 0176 & 1966 & W & $\mathrm{H}$ & 517 & S \\
\hline $\mathrm{CH}-1761$ & 394407 & 755625 & Elk & 0176 & 1968 & W & $\mathrm{H}$ & 365 & S \\
\hline $\mathrm{CH}-1765$ & 394620 & 755412 & New London & 0176 & 1966 & W & $\mathrm{H}$ & 466 & S \\
\hline $\mathrm{CH}-1770$ & 394657 & 755236 & New London & 0176 & 1966 & W & $\mathrm{H}$ & 484 & S \\
\hline $\mathrm{CH}-1776$ & 394545 & 755005 & Franklin & 0110 & 1971 & W & $\mathrm{H}$ & 315 & S \\
\hline $\mathrm{CH}-1777$ & 394536 & 755016 & Franklin & 0110 & 1971 & $U$ & $P$ & 340 & S \\
\hline $\mathrm{CH}-1778$ & 394519 & 754938 & Franklin & 0248 & 1971 & W & $P$ & 290 & S \\
\hline $\mathrm{CH}-1783$ & 394433 & 755322 & Elk & 0110 & 1972 & W & $\mathrm{H}$ & 370 & $S$ \\
\hline $\mathrm{CH}-1829$ & 394455 & 754940 & Franklin & 0154 & 1966 & W & $\mathrm{H}$ & 410 & S \\
\hline $\mathrm{CH}-1835$ & 395110 & 755321 & Londonderry & 0110 & 1971 & W & $\mathrm{H}$ & 555 & S \\
\hline $\mathrm{CH}-1996$ & 394848 & 755615 & Lower Oxford & 0176 & 1965 & W & $\mathrm{T}$ & 440 & v \\
\hline $\mathrm{CH}-2186$ & 394755 & 755839 & Lower Oxford & -- & 1941 & W & $P$ & 538 & S \\
\hline $\mathrm{CH}-2439$ & 394625 & 755850 & East Nottingham & -- & -- & W & $\mathrm{H}$ & 525 & $\mathrm{~F}$ \\
\hline $\mathrm{CH}-2440$ & 394605 & 755855 & East Nottingham & -- & -- & W & $\mathrm{H}$ & 520 & $\mathrm{~F}$ \\
\hline $\mathrm{CH}-2459$ & 394800 & 755640 & Lower Oxford & -- & -- & W & $\mathrm{H}$ & 420 & S \\
\hline $\mathrm{CH}-2460$ & 394635 & 755901 & East Nottingham & -- & -- & W & $\mathrm{H}$ & 555 & $\mathrm{~F}$ \\
\hline $\mathrm{CH}-2461$ & 394940 & 755240 & Penn & -- & -- & W & 1 & 500 & S \\
\hline $\mathrm{CH}-2673$ & 394630 & 755851 & East Nottingham & -- & -- & W & $\mathrm{H}$ & 540 & S \\
\hline $\mathrm{CH}-2678$ & 394609 & 755901 & East Nottingham & -- & -- & $\mathrm{U}$ & C & 530 & S \\
\hline CH-3039 & 394810 & 755515 & Lower Oxford & 0176 & 1967 & W & $\mathrm{H}$ & 520 & S \\
\hline $\mathrm{CH}-3316$ & 395154 & 755509 & West Fallowfield & -- & -- & W & S & 590 & $\mathrm{~F}$ \\
\hline $\mathrm{CH}-3317$ & 395142 & 755544 & Upper Oxford & -- & -- & W & $\mathrm{H}$ & 635 & $\mathrm{~F}$ \\
\hline $\mathrm{CH}-4118$ & 394638 & 755636 & East Nottingham & 1583 & 1984 & W & $\mathrm{H}$ & 500 & S \\
\hline $\mathrm{CH}-4126$ & 394752 & 755828 & Lower Oxford & 0176 & 1937 & W & $\mathrm{H}$ & 575 & $\mathrm{~F}$ \\
\hline $\mathrm{CH}-4275$ & 394656 & 755518 & East Nottingham & 1083 & 1990 & W & $\mathrm{H}$ & 411 & S \\
\hline $\mathrm{CH}-4297$ & 394752 & 755822 & Lower Oxford & 1083 & 1984 & W & $\mathrm{H}$ & 553 & S \\
\hline $\mathrm{CH}-4806$ & 394750 & 755829 & Lower Oxford & -- & 1937 & w & $\mathrm{H}$ & 574 & $\mathrm{~F}$ \\
\hline $\mathrm{CH}-4931$ & 394425 & 755333 & Elk & 1878 & 1992 & W & $\mathrm{H}$ & 410 & $\mathrm{~F}$ \\
\hline $\mathrm{CH}-4933$ & 394759 & 755601 & Lower Oxford & 0176 & 1976 & W & $\mathrm{H}$ & 480 & $\mathrm{H}$ \\
\hline $\mathrm{CH}-5231$ & 395010 & 755544 & Upper Oxford & 0384 & -- & W & $\mathrm{H}$ & 610 & $\mathrm{H}$ \\
\hline $\mathrm{CH}-5420$ & 395143 & 755256 & Londonderry & -- & -- & W & $\mathrm{H}$ & 625 & $\mathrm{~F}$ \\
\hline $\mathrm{CH}-5421$ & 394616 & 755434 & New London & -- & -- & w & $\mathrm{H}$ & 469 & $\mathrm{~F}$ \\
\hline $\mathrm{CH}-5422$ & 395141 & 755254 & Londonderry & -- & -- & W & 1 & 619 & S \\
\hline $\mathrm{CH}-5423$ & 395149 & 755359 & Londonderry & -- & -- & U & $\mathrm{H}$ & 579 & $\mathrm{~F}$ \\
\hline
\end{tabular}


Table 18. Records of selected wells, Big Elk Creek Basin, Pennsylvania and Maryland-Continued

\begin{tabular}{|c|c|c|c|c|c|c|c|c|}
\hline \multirow{2}{*}{$\begin{array}{l}\text { Hydro- } \\
\text { geologic } \\
\text { unit }\end{array}$} & \multirow{2}{*}{$\begin{array}{l}\text { Depth } \\
\text { of well } \\
\text { (feet) }\end{array}$} & \multicolumn{2}{|c|}{ Casing } & \multirow{2}{*}{$\begin{array}{l}\text { Water level } \\
\quad \text { (feet) }\end{array}$} & \multirow{2}{*}{$\begin{array}{l}\text { Date water level } \\
\text { measured }\end{array}$} & \multirow{2}{*}{$\begin{array}{l}\text { Reported } \\
\text { yield } \\
\text { (gal/min) }\end{array}$} & \multirow{2}{*}{$\begin{array}{c}\text { Specific } \\
\text { capacity } \\
\text { [(gal//min)/ft] }\end{array}$} & \multirow{2}{*}{$\begin{array}{c}\text { Well- } \\
\text { identification } \\
\text { number }\end{array}$} \\
\hline & & $\begin{array}{l}\text { Diameter } \\
\text { (inches) }\end{array}$ & $\begin{array}{l}\text { Depth } \\
\text { (feet) }\end{array}$ & & & & & \\
\hline 300WSCK & 400 & 8 & 70 & 0.00 & 19381222 & 116 & 0.8 & $\mathrm{CH}-75$ \\
\hline 300WSCK & 250 & -- & 102 & 26.33 & 19990920 & 7 & -- & $\mathrm{CH}-254$ \\
\hline 300WSCK & 184 & 8 & 38 & 20.00 & 19250101 & 38 & .2 & $\mathrm{CH}-525$ \\
\hline 300WSCK & 1,000 & 8 & -- & -- & -- & 45 & -- & $\mathrm{CH}-526$ \\
\hline 300WSCK & 478 & 8 & -- & -- & -- & 85 & -- & $\mathrm{CH}-528$ \\
\hline 300WSCK & 103 & 6 & 95 & 32.53 & 19811221 & 20 & 1.67 & $\mathrm{CH}-1702$ \\
\hline 300WSCK & 146 & 6 & 106 & 21.00 & 19740620 & 15 & .1 & $\mathrm{CH}-1703$ \\
\hline 300WSCK & 111 & 6 & 78 & 31.00 & 19740624 & 10 & .13 & $\mathrm{CH}-1720$ \\
\hline 300WSCK & 120 & 6 & 82 & 28.00 & 19700616 & 120 & 15 & $\mathrm{CH}-1722$ \\
\hline 300PRCK & 247 & 6 & 42 & 35.00 & 19740624 & 18 & .16 & $\mathrm{CH}-1724$ \\
\hline 300WSCK & 106 & 6 & 40 & 44.00 & 19670125 & 10 & .02 & $\mathrm{CH}-1735$ \\
\hline 300WSCK & 68 & 6 & 36 & 33.00 & 19660906 & 25 & 1.25 & $\mathrm{CH}-1737$ \\
\hline 000SRPN & 73 & 6 & 21 & 5.00 & 19680722 & 30 & 1.5 & $\mathrm{CH}-1761$ \\
\hline 300WSCK & 72 & 6 & 52 & 38.00 & 19660824 & 25 & 2.08 & $\mathrm{CH}-1765$ \\
\hline 300WSCK & 72 & 6 & 60 & 22.00 & 19660610 & 25 & 1.9 & $\mathrm{CH}-1770$ \\
\hline 300WSCK & 33 & 6 & 20 & 21.00 & 19710907 & 75 & 75 & $\mathrm{CH}-1776$ \\
\hline 300WSCK & 167 & 6 & 31 & 3.00 & 19711104 & 100 & 14.3 & $\mathrm{CH}-1777$ \\
\hline 300WSCK & 300 & 8 & 250 & -3.00 & 19710118 & 130 & .6 & $\mathrm{CH}-1778$ \\
\hline 300WSCK & 83 & 6 & 42 & 25.00 & 19720602 & 12 & 1.7 & $\mathrm{CH}-1783$ \\
\hline 300WSCK & 165 & 6 & 54 & 31.00 & 19661101 & 15 & .31 & $\mathrm{CH}-1829$ \\
\hline 300WSCK & 63 & 6 & 57 & 13.00 & 19740727 & 400 & 400 & $\mathrm{CH}-1835$ \\
\hline 300WSCK & 300 & 8 & 40 & 7.00 & 19650601 & 160 & 3.02 & $\mathrm{CH}-1996$ \\
\hline 300WSCK & 400 & 8 & 56 & 3.00 & 19410501 & 90 & .58 & $\mathrm{CH}-2186$ \\
\hline 300WSCK & -- & -- & -- & -- & -- & -- & -- & $\mathrm{CH}-2439$ \\
\hline 300WSCK & -- & -- & -- & -- & -- & -- & -- & $\mathrm{CH}-2440$ \\
\hline 300WSCK & -- & -- & -- & -- & -- & -- & -- & $\mathrm{CH}-2459$ \\
\hline 300WSCK & -- & -- & -- & -- & -- & -- & -- & $\mathrm{CH}-2460$ \\
\hline 300WSCK & -- & -- & -- & -- & -- & -- & -- & $\mathrm{CH}-2461$ \\
\hline 300WSCK & -- & -- & -- & -- & -- & -- & -- & $\mathrm{CH}-2673$ \\
\hline 300WSCK & -- & -- & -- & -- & -- & -- & -- & $\mathrm{CH}-2678$ \\
\hline 300WSCK & 87 & 6 & 72 & 8.00 & 19670325 & 20 & .62 & CH-3039 \\
\hline 300WSCK & -- & -- & -- & -- & -- & -- & -- & $\mathrm{CH}-3316$ \\
\hline 300PRCK & -- & -- & -- & -- & -- & -- & -- & $\mathrm{CH}-3317$ \\
\hline 300WSCK & 160 & 6 & 63 & 44.09 & 19910708 & 20 & .57 & $\mathrm{CH}-4118$ \\
\hline 300WSCK & 118 & -- & -- & -- & -- & -- & -- & $\mathrm{CH}-4126$ \\
\hline 300WSCK & -- & 6 & -- & 13.81 & 19920909 & -- & -- & $\mathrm{CH}-4275$ \\
\hline 300WSCK & 165 & 6 & 101 & 19.76 & 19921001 & 30 & -- & CH-4297 \\
\hline 300WSCK & -- & 6 & -- & -- & -- & -- & -- & $\mathrm{CH}-4806$ \\
\hline 300WSCK & 132 & 6 & 59 & 25.29 & 19940721 & 41 & 3.2 & $\mathrm{CH}-4931$ \\
\hline 300WSCK & 157 & 5 & 87 & 34.3 & 19931124 & 6 & .14 & $\mathrm{CH}-4933$ \\
\hline 300WSCK & 100 & 6 & 70 & 30.52 & 19950814 & -- & -- & $\mathrm{CH}-5231$ \\
\hline 300WSCK & 185 & 6 & -- & 14.69 & 19980609 & -- & -- & $\mathrm{CH}-5420$ \\
\hline 300WSCK & 204 & -- & -- & 54.31 & 19980202 & -- & -- & $\mathrm{CH}-5421$ \\
\hline 300WSCK & 49.4 & 6 & -- & 21.42 & 20000920 & -- & -- & CH-5422 \\
\hline 300WSCK & 70 & -- & -- & 21.78 & 19980107 & -- & -- & $\mathrm{CH}-5423$ \\
\hline
\end{tabular}


Table 18. Records of selected wells, Big Elk Creek Basin, Pennsylvania and Maryland-Continued

\begin{tabular}{|c|c|c|c|c|c|c|c|c|c|}
\hline \multirow{2}{*}{$\begin{array}{l}\text { Well- } \\
\text { identification } \\
\text { number }\end{array}$} & \multicolumn{2}{|c|}{ Location } & \multirow{2}{*}{$\begin{array}{l}\text { Township or } \\
\text { borough }\end{array}$} & \multirow{2}{*}{$\begin{array}{l}\text { Driller } \\
\text { license } \\
\text { number }\end{array}$} & \multirow{2}{*}{$\begin{array}{l}\text { Year } \\
\text { drilled }\end{array}$} & \multicolumn{2}{|c|}{ Primary } & \multirow{2}{*}{$\begin{array}{l}\text { Elevation } \\
\text { of land } \\
\text { surface }\end{array}$} & \multirow{2}{*}{$\begin{array}{l}\text { Topo- } \\
\text { graphic } \\
\text { setting }\end{array}$} \\
\hline & $\begin{array}{c}\text { Latitude } \\
\text { (degrees) }\end{array}$ & $\begin{array}{c}\text { Longitude } \\
\text { (degrees) }\end{array}$ & & & & $\begin{array}{l}\text { Use of } \\
\text { site }\end{array}$ & $\begin{array}{l}\text { Use of } \\
\text { water }\end{array}$ & & \\
\hline $\mathrm{CH}-5424$ & 394357 & 755452 & Elk & -- & -- & W & $\mathrm{H}$ & 391 & $\mathrm{~F}$ \\
\hline $\mathrm{CH}-5425$ & 395128 & 755530 & Upper Oxford & -- & -- & W & $\mathrm{H}$ & 605 & $\mathrm{H}$ \\
\hline $\mathrm{CH}-5426$ & 394703 & 755651 & East Nottingham & -- & -- & W & $\mathrm{H}$ & 506 & $\mathrm{H}$ \\
\hline $\mathrm{CH}-5427$ & 394539 & 755345 & New London & -- & -- & W & $\mathrm{H}$ & 489 & $\mathrm{~F}$ \\
\hline $\mathrm{CH}-5428$ & 395020 & 755321 & Penn & -- & -- & W & $\mathrm{H}$ & 490 & $\mathrm{~S}$ \\
\hline $\mathrm{CH}-5429$ & 394936 & 755638 & Upper Oxford & -- & -- & W & $\mathrm{H}$ & 550 & $\mathrm{~F}$ \\
\hline $\mathrm{CH}-5430$ & 394904 & 755502 & Upper Oxford & -- & -- & W & C & 531 & $\mathrm{~F}$ \\
\hline $\mathrm{CH}-5431$ & 394333 & 755210 & Elk & -- & -- & W & $\mathrm{H}$ & 396 & $\mathrm{~F}$ \\
\hline $\mathrm{CH}-5432$ & 394434 & 755700 & Elk & -- & -- & W & $\mathrm{H}$ & 400 & $\mathrm{~F}$ \\
\hline $\mathrm{CH}-5433$ & 394530 & 755030 & Franklin & -- & -- & W & $\mathrm{H}$ & 411 & $\mathrm{H}$ \\
\hline $\mathrm{CH}-5434$ & 394836 & 755252 & Penn & -- & -- & W & $\mathrm{H}$ & 550 & $S$ \\
\hline $\mathrm{CH}-5436$ & 394328 & 755203 & Elk & 1290 & 1994 & W & $\mathrm{H}$ & 375 & $\mathrm{H}$ \\
\hline $\mathrm{CH}-5437$ & 394445 & 755556 & Elk & 0319 & -- & W & $\mathrm{H}$ & 405 & $\mathrm{H}$ \\
\hline $\mathrm{CH}-5438$ & 394445 & 755557 & Elk & 0319 & -- & W & $\mathrm{H}$ & 407 & $\mathrm{H}$ \\
\hline $\mathrm{CH}-5439$ & 394348 & 755552 & Elk & -- & -- & W & $\mathrm{H}$ & 342 & $\mathrm{~F}$ \\
\hline $\mathrm{CH}-5440$ & 394645 & 755346 & New London & -- & -- & W & $\mathrm{H}$ & 393 & $S$ \\
\hline $\mathrm{CH}-5442$ & 394857 & 755648 & Lower Oxford & -- & -- & W & $\mathrm{H}$ & 561 & $S$ \\
\hline $\mathrm{CH}-5443$ & 394921 & 755255 & Penn & -- & -- & W & $\mathrm{C}$ & 522 & $\mathrm{~F}$ \\
\hline $\mathrm{CH}-5450$ & 394527 & 755156 & New London & 1083 & 1999 & W & $\mathrm{H}$ & 265 & $S$ \\
\hline $\mathrm{CH}-5470$ & 394847 & 755824 & Lower Oxford & 1715 & 1992 & W & C & 552 & $S$ \\
\hline $\mathrm{CH}-5476$ & 394732 & 755610 & East Nottingham & 0319 & 1996 & W & $\mathrm{H}$ & 412 & S \\
\hline $\mathrm{CH}-5477$ & 394620 & 755612 & East Nottingham & 1889 & 1995 & W & $\mathrm{H}$ & 482 & $\mathrm{H}$ \\
\hline $\mathrm{CH}-5479$ & 394913 & 755229 & Penn & 0176 & 1939 & W & $\mathrm{H}$ & 557 & $S$ \\
\hline CE Ae 8 & 394256 & 755023 & -- & -- & -- & $U$ & $\mathrm{H}$ & 230 & $S$ \\
\hline CE Ae 9 & 394225 & 755125 & -- & -- & -- & W & $\mathrm{H}$ & 360 & $\mathrm{H}$ \\
\hline CE Ae 13 & 394201 & 755327 & -- & -- & -- & W & $\mathrm{H}$ & 303 & $\mathrm{~S}$ \\
\hline CE Bf 77 & 393621 & 754903 & -- & -- & 1964 & W & $\mathrm{H}$ & 40 & $S$ \\
\hline
\end{tabular}


Table 18. Records of selected wells, Big Elk Creek Basin, Pennsylvania and Maryland-Continued

\begin{tabular}{|c|c|c|c|c|c|c|c|c|}
\hline \multirow{2}{*}{$\begin{array}{l}\text { Hydro- } \\
\text { geologic } \\
\text { unit }\end{array}$} & \multirow{2}{*}{$\begin{array}{l}\text { Depth } \\
\text { of well } \\
\text { (feet) }\end{array}$} & \multicolumn{2}{|c|}{ Casing } & \multirow{2}{*}{$\begin{array}{l}\text { Water level } \\
\text { (feet) }\end{array}$} & \multirow{2}{*}{$\begin{array}{l}\text { Date water level } \\
\text { measured }\end{array}$} & \multirow{2}{*}{$\begin{array}{c}\text { Reported } \\
\text { yield } \\
\text { (gal } / \text { min) }\end{array}$} & \multirow{2}{*}{$\begin{array}{c}\text { Specific } \\
\text { capacity } \\
{[(\text { gal } / \text { min }) / f t]}\end{array}$} & \multirow{2}{*}{$\begin{array}{c}\text { Well- } \\
\text { identification } \\
\text { number }\end{array}$} \\
\hline & & $\begin{array}{l}\text { Diameter } \\
\text { (inches) }\end{array}$ & $\begin{array}{c}\text { Depth } \\
\text { (feet) }\end{array}$ & & & & & \\
\hline 300WSCK & 140 & -- & -- & 2.33 & 19980624 & -- & -- & $\mathrm{CH}-5424$ \\
\hline 300PRCK & 97 & 5 & -- & 17.20 & 19980701 & -- & -- & $\mathrm{CH}-5425$ \\
\hline 300WSCK & 260 & 5 & 125 & 42.23 & -- & 6 & -- & $\mathrm{CH}-5426$ \\
\hline 300WSCK & -- & -- & -- & -- & -- & -- & -- & $\mathrm{CH}-5427$ \\
\hline 300WSCK & -- & -- & -- & 16.65 & 19980202 & -- & -- & $\mathrm{CH}-5428$ \\
\hline 300WSCK & 70 & -- & -- & -- & -- & -- & -- & $\mathrm{CH}-5429$ \\
\hline 300WSCK & -- & -- & -- & -- & -- & -- & -- & $\mathrm{CH}-5430$ \\
\hline 300WSCK & 131 & 6 & 80 & 30.85 & 19980130 & -- & -- & $\mathrm{CH}-5431$ \\
\hline 000SRPN & 118 & -- & -- & 23.29 & 19980714 & -- & -- & $\mathrm{CH}-5432$ \\
\hline 300WSCK & -- & -- & -- & 28.70 & 19980202 & -- & -- & $\mathrm{CH}-5433$ \\
\hline 300WSCK & 100 & -- & -- & 16.50 & 19980715 & -- & -- & $\mathrm{CH}-5434$ \\
\hline 300WSCK & 280 & 6 & 80 & -- & -- & 6 & -- & $\mathrm{CH}-5436$ \\
\hline 300WSCK & 150 & 6 & -- & 37.00 & 19981118 & -- & -- & $\mathrm{CH}-5437$ \\
\hline 300WSCK & 175 & 6 & 105 & -- & -- & -- & -- & $\mathrm{CH}-5438$ \\
\hline 000SRPN & 43 & -- & -- & 7.22 & 19980130 & 6 & -- & $\mathrm{CH}-5439$ \\
\hline 300WSCK & 323 & 6 & -- & 18.12 & 19981104 & -- & -- & $\mathrm{CH}-5440$ \\
\hline 300WSCK & 75 & -- & -- & -- & -- & -- & -- & $\mathrm{CH}-5442$ \\
\hline 300WSCK & 111 & 6 & -- & 37.36 & 19981112 & -- & -- & $\mathrm{CH}-5443$ \\
\hline 000PGMT & 302 & 6 & 81 & 20.36 & 20000911 & 30 & -- & $\mathrm{CH}-5450$ \\
\hline 300PRCK & 120 & 6 & 97 & 24.95 & 19960822 & 45 & 0.08 & $\mathrm{CH}-5470$ \\
\hline 300WSCK & 390 & 6 & 70 & 31.76 & 19960904 & 8 & -- & $\mathrm{CH}-5476$ \\
\hline 300WSCK & 345 & 6 & 92 & 43.39 & 19960904 & 4 & -- & $\mathrm{CH}-5477$ \\
\hline 300WSCK & 105 & 5 & -- & 8.00 & 19960905 & -- & -- & $\mathrm{CH}-5479$ \\
\hline 300MGCK & 78 & -- & -- & 58.70 & 19980202 & -- & -- & $\mathrm{CE}$ Ae 8 \\
\hline 300MGCK & 235 & -- & -- & 15.75 & 19980203 & -- & -- & CE Ae 9 \\
\hline 300MGCK & 201 & -- & -- & 46.15 & -- & -- & -- & $\mathrm{CE} \mathrm{Ae} 13$ \\
\hline 300UFGB & 201 & 6 & 135 & $\mathrm{~F}$ & 19640428 & 25 & -- & CE Bf 77 \\
\hline
\end{tabular}


Table 19. Water-level measurements, Big Elk Creek Basin, Pennsylvania and Maryland [--, no data]

\begin{tabular}{|c|c|c|c|c|c|c|c|c|c|c|c|}
\hline Date & CH-5421 & CH-5423 & CH-5425 & CH-5427 & CH-5428 & CH-5429 & CH-5433 & CE Ae 8 & CE Ae 9 & Date & CH-254 \\
\hline $01 / 15 / 1998$ & 54.31 & 21.78 & 21.18 & 65.30 & 16.65 & 4.25 & 28.70 & 24.57 & 15.75 & $1 / 20 / 1998$ & 23.75 \\
\hline 02/27/1998 & 53.46 & 19.27 & 17.91 & 58.56 & 14.96 & 3.85 & 26.50 & 23.23 & 15.09 & 2/24/1998 & 22.55 \\
\hline 03/27/1998 & 51.25 & 17.62 & 15.79 & 65.45 & 14.65 & 3.10 & 19.42 & 21.14 & 13.62 & 3/23/1998 & 20.60 \\
\hline 04/29/1998 & 51.01 & 17.30 & 17.13 & 54.90 & 14.48 & 3.60 & 18.36 & 18.56 & 13.95 & 4/21/1998 & 19.12 \\
\hline 05/28/1998 & 50.75 & 16.89 & 17.87 & 56.25 & 14.43 & 3.77 & 18.92 & 21.85 & 14.01 & 5/21/1998 & 18.40 \\
\hline 06/18/1998 & 51.40 & 17.00 & 17.72 & 55.80 & 16.08 & 5.18 & 19.79 & 20.00 & 14.89 & 6/22/1998 & 18.22 \\
\hline 07/24/1998 & 52.00 & 18.01 & 19.36 & -- & 17.23 & 4.87 & 26.10 & -- & -- & 7/20/1998 & 18.73 \\
\hline 08/15/1998 & 53.04 & 18.93 & 20.52 & 57.08 & 18.49 & 5.17 & 22.41 & 21.87 & 16.85 & 8/21/1998 & 19.74 \\
\hline 10/29/1998 & 55.60 & 20.20 & 20.28 & 58.52 & 18.46 & 5.79 & 25.02 & -- & 17.98 & 10/20/1998 & 21.90 \\
\hline $12 / 08 / 1998$ & 55.07 & 21.20 & 21.27 & 57.91 & 19.29 & 5.70 & 25.35 & 23.75 & 18.62 & $11 / 24 / 1998$ & 23.13 \\
\hline 01/07/1999 & 55.69 & 21.45 & 20.43 & 62.87 & 18.91 & 5.40 & 25.63 & 24.14 & 18.90 & 12/22/1998 & 23.99 \\
\hline 01/22/1999 & 55.34 & 20.55 & 18.95 & 67.45 & 17.31 & 4.22 & 26.15 & 24.03 & 18.46 & 1/20/1999 & 24.61 \\
\hline 02/24/1999 & 54.71 & 19.45 & 18.17 & 61.48 & 15.67 & 4.23 & 29.25 & 24.25 & 17.29 & 2/22/1999 & 24.61 \\
\hline 03/23/1999 & 54.19 & 18.49 & 16.75 & 64.42 & 15.05 & 3.47 & 24.49 & 23.87 & 16.45 & 3/19/1999 & 24.50 \\
\hline 04/19/1999 & 53.61 & 18.40 & 17.84 & 58.66 & 15.19 & 3.54 & 21.96 & 22.27 & 15.79 & 4/21/1999 & 23.66 \\
\hline 05/20/1999 & 53.38 & 18.92 & 18.82 & 57.72 & 16.37 & 4.18 & 20.98 & 21.85 & 16.11 & 5/20/1999 & 23.60 \\
\hline 06/22/1999 & 54.55 & 19.60 & 19.82 & 63.08 & 17.75 & 5.38 & 21.88 & 21.82 & 17.04 & 6/29/1999 & 24.45 \\
\hline 07/23/1999 & 55.97 & 21.10 & 21.17 & 63.83 & 18.98 & 6.97 & 23.26 & 22.34 & 18.16 & 7/19/1999 & 24.95 \\
\hline 08/18/1999 & 56.03 & 22.72 & 23.21 & 64.64 & 20.53 & 9.45 & 24.05 & 23.08 & 19.21 & 8/19/1999 & 25.88 \\
\hline 09/22/1999 & 54.44 & 21.17 & 18.62 & 58.92 & 18.14 & 4.75 & 24.35 & 22.67 & 18.75 & 9/20/1999 & 26.33 \\
\hline 10/18/1999 & 52.97 & 20.12 & 17.63 & -- & 15.68 & 4.28 & 22.36 & 21.81 & 18.10 & 10/19/1999 & 25.63 \\
\hline $11 / 18 / 1999$ & 53.00 & 20.10 & 19.04 & 60.88 & 16.28 & 4.46 & 21.48 & 21.22 & 17.76 & 11/22/1999 & 25.50 \\
\hline $12 / 21 / 1999$ & 53.17 & 19.26 & 17.57 & 55.95 & 15.46 & 3.25 & 21.67 & 20.99 & 17.05 & 12/20/1999 & 25.47 \\
\hline $01 / 24 / 2000$ & 52.53 & 19.09 & 18.57 & 53.92 & 15.78 & 3.99 & 21.85 & 20.97 & 16.71 & $1 / 21 / 2000$ & 25.00 \\
\hline
\end{tabular}


Table 20. Results of field determinations and laboratory analyses for selected inorganic constituents in ground water, Big Elk Creek Basin, Pennsylvania and Maryland

$\mu \mathrm{S} / \mathrm{cm}$, microsiemens per centimeter at 25 degrees Celsius;

${ }^{\circ} \mathrm{C}$, degrees Celsius;

$\mathrm{mg} / \mathrm{L}$, milligram per liter;

$\mu \mathrm{g} / \mathrm{L}$, micrograms per liter;

ND, not detected with detection limit not reported;

$<$, less than;

--, no data;

E, estimated concentration;

$\mathrm{U}$, below detection limit, detection limit unknown;

Geologic Unit Codes:

300WSCK, Wissahickon Schist;

300PRCK, Peters Creek Schist;

O0OSPRN, serpentinite;

000PGMT, pegmatite;

300UFGB, gabbro and serpentinite at Gray's Hill;

300MGCK, metagraywacke 
Table 20. Results of field determinations and laboratory analyses for selected inorganic constituents, Big Elk Creek Basin, Pennsylvania and Maryland-Continued

\begin{tabular}{|c|c|c|c|c|c|c|c|}
\hline $\begin{array}{c}\text { Well- } \\
\text { identification } \\
\text { number }\end{array}$ & $\begin{array}{c}\text { Geologic } \\
\text { unit }\end{array}$ & $\begin{array}{c}\text { Sample } \\
\text { date }\end{array}$ & $\begin{array}{c}\text { Dissolved } \\
\text { oxygen } \\
\text { (mg/L) }\end{array}$ & $\begin{array}{c}\text { pH } \\
\text { (standard } \\
\text { units) }\end{array}$ & $\begin{array}{c}\text { Specific } \\
\text { conduc- } \\
\text { tance } \\
(\mu \mathrm{S} / \mathrm{cm})\end{array}$ & $\begin{array}{c}\text { Alkalinity } \\
\text { (mg/L as } \\
\left.\mathrm{CaCO}_{3}\right)\end{array}$ & $\begin{array}{c}\text { Water } \\
\text { temperature } \\
\left({ }^{\circ} \mathrm{C}\right)\end{array}$ \\
\hline $\mathrm{CH}-75$ & 300WSCK & $7 / 14 / 86$ & -- & 5.6 & 165 & -- & 14 \\
\hline $\mathrm{CH}-75$ & 300WSCK & 8/23/90 & 8.5 & 5.2 & 192 & 90 & 13 \\
\hline $\mathrm{CH}-75$ & $300 W S C K$ & $8 / 8 / 00$ & 5.7 & 5.6 & 227 & -- & 14.1 \\
\hline $\mathrm{CH}-525$ & $300 W S C K$ & 9/21/25 & -- & -- & -- & 18 & -- \\
\hline $\mathrm{CH}-526$ & 300WSCK & 9/21/25 & -- & -- & -- & 26 & -- \\
\hline $\mathrm{CH}-528$ & 300 WSCK & $9 / 21 / 25$ & -- & -- & -- & 13 & -- \\
\hline $\mathrm{CH}-1702$ & $300 W S C K$ & $10 / 14 / 74$ & -- & 5.9 & 50 & 9 & \\
\hline $\mathrm{CH}-1703$ & $300 W S C K$ & $8 / 5 / 91$ & 7.5 & 6.4 & 76 & 52 & 14.5 \\
\hline $\mathrm{CH}-1720$ & 300WSCK & 10/1/92 & 5.9 & 6 & 239 & -- & 13.5 \\
\hline $\mathrm{CH}-1720$ & 300WSCK & $4 / 6 / 93$ & 6.3 & 5.9 & 240 & 52 & 13 \\
\hline $\mathrm{CH}-1720$ & $300 W S C K$ & 6/10/93 & 6 & 5.9 & 253 & -- & 13.5 \\
\hline $\mathrm{CH}-1720$ & 300WSCK & 9/16/93 & 6.9 & 5.9 & 302 & -- & 13.5 \\
\hline $\mathrm{CH}-1724$ & 300PRCK & $10 / 14 / 74$ & -- & 6.2 & 115 & -- & -- \\
\hline $\mathrm{CH}-1735$ & 300WSCK & $9 / 6 / 00$ & 9.4 & 5.4 & 283 & 16 & 14.7 \\
\hline $\mathrm{CH}-1737$ & 300WSCK & $7 / 11 / 91$ & 7.6 & 6.4 & 235 & 28 & 14 \\
\hline $\mathrm{CH}-1761$ & 000SRPN & 8/22/91 & 1.8 & 8.5 & 457 & -- & 14 \\
\hline $\mathrm{CH}-1765$ & $300 \mathrm{WSCK}$ & 8/22/91 & 9.9 & 5.7 & 164 & 10 & 13.5 \\
\hline $\mathrm{CH}-1770$ & $300 W S C K$ & $10 / 15 / 74$ & -- & 5.8 & 190 & 8 & -- \\
\hline $\mathrm{CH}-1776$ & 300WSCK & $10 / 15 / 74$ & -- & 6.4 & 70 & 10 & -- \\
\hline $\mathrm{CH}-1777$ & 300WSCK & $8 / 1 / 74$ & -- & 7.2 & -- & 35 & -- \\
\hline $\mathrm{CH}-1778$ & $300 W S C K$ & $1 / 14 / 71$ & -- & 7.7 & -- & 41 & -- \\
\hline $\mathrm{CH}-1783$ & 300 WSCK & $10 / 15 / 74$ & -- & 6.2 & 80 & 15 & -- \\
\hline $\mathrm{CH}-1829$ & $300 W S C K$ & 8/31/95 & 7 & 5.3 & 849 & 12 & 13.5 \\
\hline $\mathrm{CH}-1835$ & 300WSCK & $10 / 14 / 74$ & -- & 5.7 & 70 & 7 & -- \\
\hline $\mathrm{CH}-1996$ & 300WSCK & 2/27/74 & -- & 6.0 & -- & 27 & -- \\
\hline $\mathrm{CH}-2186$ & 300WSCK & 8/18/93 & 7.2 & 6.1 & 141 & 20 & 13.5 \\
\hline $\mathrm{CH}-2439$ & 300WSCK & $8 / 17 / 81$ & -- & 5.9 & 105 & -- & 17 \\
\hline $\mathrm{CH}-2440$ & $300 W S C K$ & $8 / 17 / 81$ & -- & 5.7 & 180 & -- & 18 \\
\hline $\mathrm{CH}-2459$ & 300WSCK & $8 / 4 / 82$ & -- & 5.4 & 105 & -- & 11.5 \\
\hline $\mathrm{CH}-2460$ & 300WSCK & $8 / 4 / 82$ & -- & 5.6 & 235 & -- & 14 \\
\hline $\mathrm{CH}-2461$ & 300WSCK & $8 / 4 / 82$ & -- & 5.7 & 130 & -- & 13.5 \\
\hline $\mathrm{CH}-2461$ & 300WSCK & 7/7/83 & -- & 5.8 & 165 & -- & 13 \\
\hline $\mathrm{CH}-2461$ & 300WSCK & $8 / 8 / 95$ & 6.4 & 5.8 & 229 & 22 & 13.5 \\
\hline $\mathrm{CH}-2673$ & 300WSCK & $8 / 6 / 85$ & -- & 5.7 & 208 & 40 & 16 \\
\hline $\mathrm{CH}-2678$ & 300WSCK & 8/28/84 & -- & 5.8 & 225 & -- & 14.5 \\
\hline $\mathrm{CH}-2678$ & $300 W S C K$ & $6 / 25 / 85$ & -- & 5.7 & 265 & 20 & 15 \\
\hline $\mathrm{CH}-3316$ & 300WSCK & 8/8/88 & -- & 6.7 & 180 & -- & 13 \\
\hline $\mathrm{CH}-3316$ & 300WSCK & $9 / 6 / 90$ & 0 & 6.8 & 193 & 57 & 12.5 \\
\hline $\mathrm{CH}-3317$ & 300PRCK & 8/8/88 & -- & 4.8 & 500 & -- & 15 \\
\hline $\mathrm{CH}-4118$ & 300WSCK & $7 / 8 / 91$ & 9 & 5.7 & 94 & 8 & 14 \\
\hline $\mathrm{CH}-4126$ & 300WSCK & $8 / 7 / 91$ & 9.2 & 5.9 & 202 & 14 & 13.5 \\
\hline $\mathrm{CH}-4275$ & $300 \mathrm{WSCK}$ & 9/9/92 & 7.1 & 6 & 154 & 21 & 14 \\
\hline
\end{tabular}


Table 20. Results of field determinations and laboratory analyses for selected inorganic constituents, Big Elk Creek Basin, Pennsylvania and Maryland-Continued

\begin{tabular}{|c|c|c|c|c|c|c|c|c|}
\hline $\begin{array}{c}\text { Well- } \\
\text { identification } \\
\text { number }\end{array}$ & $\begin{array}{c}\text { Sample } \\
\text { date }\end{array}$ & $\begin{array}{c}\text { Total } \\
\text { hardness } \\
(\mathrm{mg} / \mathrm{L} \text { as } \\
\left.\mathrm{CaCO}_{3}\right)\end{array}$ & $\begin{array}{c}\text { Calcium, } \\
\text { dissolved } \\
\text { (mg/L } \\
\text { as Ca) }\end{array}$ & $\begin{array}{c}\text { Magnesium, } \\
\text { dissolved } \\
(\mathrm{mg} / \mathrm{L} \\
\text { as } \mathrm{Mg})\end{array}$ & $\begin{array}{l}\text { Potassium, } \\
\text { dissolved } \\
\text { (mg/L } \\
\text { as K) }\end{array}$ & $\begin{array}{l}\text { Sodium, } \\
\text { dissolved } \\
(\mathrm{mg} / \mathrm{L} \\
\text { as } \mathrm{Na})\end{array}$ & $\begin{array}{c}\text { Chloride, } \\
\text { dissolved } \\
\text { (mg/L } \\
\text { as } \mathrm{Cl})\end{array}$ & $\begin{array}{c}\text { Fluoride, } \\
\text { dissolved } \\
\text { (mg/L } \\
\text { as F) }\end{array}$ \\
\hline $\mathrm{CH}-75$ & $7 / 14 / 86$ & -- & -- & -- & -- & -- & 21 & -- \\
\hline $\mathrm{CH}-75$ & 8/23/90 & -- & -- & -- & -- & -- & 26 & -- \\
\hline $\mathrm{CH}-75$ & $8 / 8 / 00$ & 65 & 13.6 & 7.62 & 2.5 & 12.1 & 33 & $<0.1$ \\
\hline $\mathrm{CH}-525$ & $9 / 21 / 25$ & 32 & 5.4 & 4.6 & 1.6 & 3.7 & 4 & -- \\
\hline $\mathrm{CH}-526$ & $9 / 21 / 25$ & 28 & 6 & 3.2 & 1.8 & 4.5 & 1.8 & -- \\
\hline $\mathrm{CH}-528$ & $9 / 21 / 25$ & 18 & 3.9 & 1.9 & 1.3 & 2.8 & 1.9 & -- \\
\hline $\mathrm{CH}-1702$ & $10 / 14 / 74$ & 9 & 1.9 & 1 & .4 & 2.5 & 2 & .1 \\
\hline $\mathrm{CH}-1703$ & $8 / 5 / 91$ & 15 & 3.2 & 1.8 & 1.5 & 5.2 & 3 & .1 \\
\hline $\mathrm{CH}-1720$ & 10/1/92 & -- & -- & -- & -- & -- & 21 & $<.1$ \\
\hline $\mathrm{CH}-1720$ & $4 / 6 / 93$ & 73 & 17 & 7.5 & 3 & 15 & 22 & $<.1$ \\
\hline $\mathrm{CH}-1720$ & 6/10/93 & 80 & 19 & 8 & 3 & 16 & 27 & $<.1$ \\
\hline $\mathrm{CH}-1720$ & 9/16/93 & 81 & 19 & 8.1 & 2.9 & 24 & 40 & $<.1$ \\
\hline $\mathrm{CH}-1724$ & $10 / 14 / 74$ & 27 & 5.6 & 3.2 & .7 & 5.5 & 5 & .1 \\
\hline $\mathrm{CH}-1735$ & $9 / 6 / 00$ & 37 & 9.26 & 3.35 & 2.9 & 33.3 & 38.8 & $<.1$ \\
\hline $\mathrm{CH}-1737$ & $7 / 11 / 91$ & 52 & 11 & 5.9 & 1 & 9.8 & 16 & $<.1$ \\
\hline $\mathrm{CH}-1761$ & $8 / 22 / 91$ & 250 & 4.2 & 59 & .2 & 2.3 & 5.4 & $<.1$ \\
\hline $\mathrm{CH}-1765$ & $8 / 22 / 91$ & 51 & 9.4 & 6.6 & 2.1 & 5.2 & 20 & $<.1$ \\
\hline $\mathrm{CH}-1770$ & $10 / 15 / 74$ & 47 & 6.5 & 7.5 & 2 & 8.1 & 20 & .1 \\
\hline $\mathrm{CH}-1776$ & $10 / 15 / 74$ & 10 & 2.5 & .8 & 1.2 & 4.4 & 3.3 & .1 \\
\hline $\mathrm{CH}-1777$ & $8 / 1 / 74$ & 36 & -- & -- & -- & -- & 4.5 & .2 \\
\hline $\mathrm{CH}-1778$ & $1 / 14 / 71$ & 34 & -- & -- & -- & -- & 13 & 0 \\
\hline $\mathrm{CH}-1783$ & $10 / 15 / 74$ & 17 & 3.5 & 1.9 & 1.3 & 4.9 & 5 & .1 \\
\hline CH-1829 & 8/31/95 & -- & -- & -- & -- & -- & 130 & -- \\
\hline $\mathrm{CH}-1835$ & $10 / 14 / 74$ & 11 & 2 & 1.5 & .6 & 3.1 & 4.8 & .1 \\
\hline $\mathrm{CH}-1996$ & 2/27/74 & 48 & & & & & 5.5 & .1 \\
\hline $\mathrm{CH}-2186$ & 8/18/93 & 47 & 11 & 4.8 & 1.7 & 6.5 & 8.3 & $<0.1$ \\
\hline CH-2439 & $8 / 17 / 81$ & -- & -- & -- & -- & -- & -- & -- \\
\hline $\mathrm{CH}-2440$ & $8 / 17 / 81$ & -- & -- & -- & -- & -- & -- & -- \\
\hline $\mathrm{CH}-2459$ & $8 / 4 / 82$ & -- & -- & -- & -- & -- & -- & -- \\
\hline $\mathrm{CH}-2460$ & $8 / 4 / 82$ & -- & -- & -- & -- & -- & -- & -- \\
\hline $\mathrm{CH}-2461$ & $8 / 4 / 82$ & -- & -- & -- & -- & -- & -- & -- \\
\hline $\mathrm{CH}-2461$ & 7/7/83 & -- & -- & -- & -- & -- & -- & -- \\
\hline $\mathrm{CH}-2461$ & $8 / 8 / 95$ & 71 & 16 & 7.5 & 3 & 7.9 & 10 & $<.1$ \\
\hline $\mathrm{CH}-2673$ & $8 / 6 / 85$ & -- & -- & -- & -- & -- & -- & -- \\
\hline CH-2678 & 8/28/84 & -- & -- & -- & -- & -- & -- & -- \\
\hline $\mathrm{CH}-2678$ & $6 / 25 / 85$ & 81 & 19 & 8.2 & -- & 12 & 51 & -- \\
\hline $\mathrm{CH}-3316$ & 8/8/88 & -- & -- & -- & -- & -- & 5.7 & -- \\
\hline $\mathrm{CH}-3316$ & 9/6/90 & -- & -- & -- & -- & -- & 6.7 & -- \\
\hline CH-3317 & 8/8/88 & -- & -- & -- & -- & -- & 150 & -- \\
\hline $\mathrm{CH}-4118$ & $7 / 8 / 91$ & 27 & 2.6 & 5 & 1.3 & 2.9 & 6.1 & $<.1$ \\
\hline $\mathrm{CH}-4126$ & $8 / 7 / 91$ & -- & -- & -- & -- & -- & 31 & $<.1$ \\
\hline $\mathrm{CH}-4275$ & 9/9/92 & -- & -- & -- & -- & -- & 17 & $<.1$ \\
\hline
\end{tabular}


Table 20. Results of field determinations and laboratory analyses for selected inorganic constituents, Big Elk Creek Basin, Pennsylvania and Maryland-Continued

\begin{tabular}{|c|c|c|c|c|c|c|c|c|}
\hline $\begin{array}{c}\text { Well- } \\
\text { identification } \\
\text { number }\end{array}$ & $\begin{array}{c}\text { Sample } \\
\text { date }\end{array}$ & $\begin{array}{c}\text { Silica, } \\
\text { dissolved } \\
(\mathrm{mg} / \mathrm{L} \\
\left.\text { as } \mathrm{SiO}_{2}\right)\end{array}$ & $\begin{array}{c}\text { Sulfate, } \\
\text { dissolved } \\
\left(\mathrm{mg} / \mathrm{L} \text { as } \mathrm{SO}_{4}\right)\end{array}$ & $\begin{array}{c}\text { Solids, } \\
\text { residue at } 180{ }^{\circ} \mathrm{C}, \\
\text { dissolved } \\
(\mathrm{mg} / \mathrm{L})\end{array}$ & $\begin{array}{l}\text { Radon-222, } \\
\text { dissolved } \\
(\mathrm{pCi} / \mathrm{L})\end{array}$ & $\begin{array}{c}\mathrm{NO}_{2}+\mathrm{NO}_{3} \\
\text { dissolved } \\
\text { (mg/L as } \mathrm{N} \text { ) }\end{array}$ & $\begin{array}{c}\text { Nitrogen } \\
\text { nitrate, } \\
\text { dissolved } \\
(\mathrm{mg} / \mathrm{L} \text { as } \mathrm{N})\end{array}$ & $\begin{array}{c}\text { Nitrogen } \\
\text { nitrite, } \\
\text { dissolved } \\
(\mathrm{mg} / \mathrm{L} \text { as } \mathrm{N})\end{array}$ \\
\hline $\mathrm{CH}-75$ & $7 / 14 / 86$ & -- & 5 & 110 & 4,200 & 7.6 & 7.58 & 0.02 \\
\hline $\mathrm{CH}-75$ & 8/23/90 & -- & 16 & 125 & 2,900 & 7.4 & -- & $<.010$ \\
\hline $\mathrm{CH}-75$ & $8 / 8 / 00$ & 16.6 & 12.1 & -- & -- & 4.75 & -- & $<.010$ \\
\hline $\mathrm{CH}-525$ & $9 / 21 / 25$ & 23 & 5 & 74 & -- & -- & 3.6 & -- \\
\hline $\mathrm{CH}-526$ & $9 / 21 / 25$ & 24 & 8.9 & 68 & -- & -- & .12 & -- \\
\hline $\mathrm{CH}-528$ & $9 / 21 / 25$ & 18 & 4.9 & 48 & -- & -- & 1.3 & -- \\
\hline $\mathrm{CH}-1702$ & $10 / 14 / 74$ & 14 & 5.1 & 33 & -- & 1.1 & 1.1 & $<.010$ \\
\hline $\mathrm{CH}-1703$ & $8 / 5 / 91$ & 19 & 3 & 57 & 2,900 & 2.2 & -- & $<.010$ \\
\hline $\mathrm{CH}-1720$ & 10/1/92 & -- & 2.4 & 164 & 3,900 & 11 & -- & $<.010$ \\
\hline $\mathrm{CH}-1720$ & $4 / 6 / 93$ & 28 & 3 & 185 & 4,500 & 11 & -- & $<.010$ \\
\hline $\mathrm{CH}-1720$ & 6/10/93 & 28 & 3.4 & 200 & 3,800 & 11 & -- & $<.010$ \\
\hline $\mathrm{CH}-1720$ & 9/16/93 & 30 & 4 & 198 & 4,100 & 13 & -- & $<.010$ \\
\hline $\mathrm{CH}-1724$ & $10 / 14 / 74$ & 14 & $<1.0$ & 79 & -- & 4.1 & 4.1 & $<.010$ \\
\hline $\mathrm{CH}-1735$ & $9 / 6 / 00$ & 17.1 & 10.4 & -- & 4,400 & 8.47 & -- & $<.010$ \\
\hline $\mathrm{CH}-1737$ & 7/11/91 & 14 & 4.6 & 113 & $2 ; 500$ & 14 & -- & $<.010$ \\
\hline $\mathrm{CH}-1761$ & 8/22/91 & 28 & 3.5 & 239 & 120 & .05 & -- & $<.010$ \\
\hline $\mathrm{CH}-1765$ & 8/22/91 & 13 & 3 & 115 & 1,400 & 8 & -- & $<.010$ \\
\hline $\mathrm{CH}-1770$ & $10 / 15 / 74$ & 11 & .5 & 112 & -- & 9.7 & 9.7 & $<.010$ \\
\hline $\mathrm{CH}-1776$ & $10 / 15 / 74$ & 15 & 2.9 & 50 & -- & .18 & .18 & $<.010$ \\
\hline $\mathrm{CH}-1777$ & $8 / 1 / 74$ & -- & 12 & 89 & -- & -- & .42 & -- \\
\hline $\mathrm{CH}-1778$ & $1 / 14 / 71$ & -- & 7 & 112 & -- & -- & .71 & -- \\
\hline $\mathrm{CH}-1783$ & $10 / 15 / 74$ & 16 & 1.4 & 57 & -- & 2.1 & 2.1 & $<.010$ \\
\hline $\mathrm{CH}-1829$ & 8/31/95 & -- & -- & -- & 1,500 & 36 & -- & $<.010$ \\
\hline $\mathrm{CH}-1835$ & $10 / 14 / 74$ & 10 & $<1.0$ & 40 & -- & 2 & 2 & $<.010$ \\
\hline $\mathrm{CH}-1996$ & 2/27/74 & -- & 3 & 86 & -- & -- & 3.5 & -- \\
\hline $\mathrm{CH}-2186$ & 8/18/93 & 17 & 5.3 & -- & 5,200 & 7.1 & -- & $<.010$ \\
\hline $\mathrm{CH}-2439$ & 8/17/81 & -- & -- & -- & -- & 3.1 & 3.09 & .01 \\
\hline $\mathrm{CH}-2440$ & 8/17/81 & -- & -- & -- & -- & 2.9 & 2.89 & .01 \\
\hline $\mathrm{CH}-2459$ & $8 / 4 / 82$ & -- & -- & -- & -- & -- & -- & -- \\
\hline $\mathrm{CH}-2460$ & $8 / 4 / 82$ & -- & -- & -- & -- & -- & -- & -- \\
\hline $\mathrm{CH}-2461$ & $8 / 4 / 82$ & -- & -- & -- & -- & -- & -- & -- \\
\hline $\mathrm{CH}-2461$ & $7 / 7 / 83$ & -- & -- & -- & -- & 7 & -- & $<.010$ \\
\hline $\mathrm{CH}-2461$ & 8/8/95 & 20 & 2.6 & -- & 3,000 & 15 & -- & $<.010$ \\
\hline $\mathrm{CH}-2673$ & $8 / 6 / 85$ & -- & -- & -- & -- & 9.8 & 9.78 & .02 \\
\hline $\mathrm{CH}-2678$ & $8 / 28 / 84$ & -- & -- & -- & -- & 7.3 & -- & $<.010$ \\
\hline $\mathrm{CH}-2678$ & $6 / 25 / 85$ & -- & 1.1 & 226 & -- & 2.2 & -- & $<.010$ \\
\hline $\mathrm{CH}-3316$ & 8/8/88 & -- & 21 & 122 & -- & $<0.100$ & -- & $<.010$ \\
\hline $\mathrm{CH}-3316$ & $9 / 6 / 90$ & -- & 21 & 119 & 11,000 & $<.100$ & -- & $<.010$ \\
\hline $\mathrm{CH}-3317$ & 8/8/88 & -- & .7 & 263 & -- & 2.9 & -- & $<.010$ \\
\hline $\mathrm{CH}-4118$ & $7 / 8 / 91$ & 7.5 & .2 & 56 & 1,400 & 6.8 & -- & $<.010$ \\
\hline $\mathrm{CH}-4126$ & $8 / 7 / 91$ & -- & .2 & 135 & 5,100 & 6.5 & -- & $<.010$ \\
\hline $\mathrm{CH}-4275$ & 9/9/92 & -- & 7 & 107 & 4,200 & 5.9 & -- & $<.010$ \\
\hline
\end{tabular}


Table 20. Results of field determinations and laboratory analyses for selected inorganic constituents, Big Elk Creek Basin, Pennsylvania and Maryland-Continued

\begin{tabular}{|c|c|c|c|c|c|c|c|c|}
\hline $\begin{array}{c}\text { Well- } \\
\text { identification } \\
\text { number }\end{array}$ & $\begin{array}{l}\text { Sample } \\
\text { date }\end{array}$ & $\begin{array}{c}\text { Nitrogen } \\
\text { ammonia, } \\
\text { dissolved } \\
\text { (mg/L as N) }\end{array}$ & $\begin{array}{c}\text { Phosphate, } \\
\text { ortho, } \\
\text { dissolved } \\
\left(\mathrm{mg} / \mathrm{L} \text { as } \mathrm{PO}_{4}\right)\end{array}$ & $\begin{array}{l}\text { Phosphorus, } \\
\text { dissolved } \\
\text { (mg/L as } \mathrm{P} \text { ) }\end{array}$ & $\begin{array}{c}\text { Phosphate, } \\
\text { ortho, } \\
\text { dissolved } \\
\text { (mg/L as } \mathrm{P})\end{array}$ & $\begin{array}{c}\text { Aluminum, } \\
\text { dissolved } \\
(\mu \mathrm{g} / \mathrm{L} \text { as Al) }\end{array}$ & $\begin{array}{c}\text { Antimony, } \\
\text { dissolved } \\
(\mu \mathrm{g} / \mathrm{L} \text { as } \mathrm{Sb})\end{array}$ & $\begin{array}{c}\text { Arsenic, } \\
\text { dissolved } \\
(\mu \mathrm{g} / \mathrm{L} \text { as As })\end{array}$ \\
\hline $\mathrm{CH}-75$ & $7 / 14 / 86$ & 0.02 & 0.061 & 0.02 & 0.02 & -- & -- & -- \\
\hline $\mathrm{CH}-75$ & $8 / 23 / 90$ & $<.010$ & -- & -- & -- & -- & -- & $<1.0$ \\
\hline $\mathrm{CH}-75$ & $8 / 8 / 00$ & $<.020$ & .04 & .019 & .013 & -- & -- & -- \\
\hline $\mathrm{CH}-525$ & $9 / 21 / 25$ & -- & -- & -- & -- & -- & -- & -- \\
\hline $\mathrm{CH}-526$ & $9 / 21 / 25$ & -- & -- & -- & -- & -- & -- & -- \\
\hline $\mathrm{CH}-528$ & 9/21/25 & -- & -- & -- & -- & -- & -- & -- \\
\hline $\mathrm{CH}-1702$ & $10 / 14 / 74$ & .02 & 0 & -- & $<.010$ & 10 & -- & $<1.0$ \\
\hline $\mathrm{CH}-1703$ & $8 / 5 / 91$ & $<.010$ & .092 & -- & .03 & -- & -- & -- \\
\hline $\mathrm{CH}-1720$ & $10 / 1 / 92$ & $<.010$ & .123 & -- & .04 & -- & -- & $<1.0$ \\
\hline $\mathrm{CH}-1720$ & $4 / 6 / 93$ & .01 & .153 & -- & .05 & -- & -- & -- \\
\hline $\mathrm{CH}-1720$ & 6/10/93 & .01 & .184 & -- & .06 & -- & -- & -- \\
\hline $\mathrm{CH}-1720$ & $9 / 16 / 93$ & .01 & .123 & -- & .04 & -- & -- & -- \\
\hline $\mathrm{CH}-1724$ & $10 / 14 / 74$ & .01 & .123 & -- & .04 & 10 & -- & 2 \\
\hline $\mathrm{CH}-1735$ & $9 / 6 / 00$ & $<.020$ & .126 & .047 & .041 & -- & -- & $<2.0$ \\
\hline $\mathrm{CH}-1737$ & $7 / 11 / 91$ & .02 & .092 & -- & .03 & -- & -- & -- \\
\hline $\mathrm{CH}-1761$ & 8/22/91 & .02 & .061 & -- & .02 & -- & -- & -- \\
\hline $\mathrm{CH}-1765$ & $8 / 22 / 91$ & .01 & .031 & -- & .01 & -- & -- & -- \\
\hline $\mathrm{CH}-1770$ & $10 / 15 / 74$ & .03 & .031 & -- & .01 & 50 & -- & $<1.0$ \\
\hline $\mathrm{CH}-1776$ & $10 / 15 / 74$ & .01 & .153 & -- & .05 & $<100$ & -- & $<1.0$ \\
\hline $\mathrm{CH}-1777$ & $8 / 1 / 74$ & -- & .061 & -- & .02 & -- & -- & -- \\
\hline $\mathrm{CH}-1778$ & $1 / 14 / 71$ & -- & -- & -- & -- & -- & -- & -- \\
\hline $\mathrm{CH}-1783$ & $10 / 15 / 74$ & .03 & .092 & -- & .03 & $<100$ & -- & $<1.0$ \\
\hline $\mathrm{CH}-1829$ & $8 / 31 / 95$ & $<.015$ & .031 & -- & .01 & -- & -- & -- \\
\hline $\mathrm{CH}-1835$ & $10 / 14 / 74$ & .01 & .061 & -- & .02 & 20 & -- & $<1.0$ \\
\hline $\mathrm{CH}-1996$ & $2 / 27 / 74$ & -- & .031 & -- & .01 & -- & -- & -- \\
\hline $\mathrm{CH}-2186$ & 8/18/93 & $<.010$ & .061 & -- & .02 & -- & -- & -- \\
\hline $\mathrm{CH}-2439$ & $8 / 17 / 81$ & .01 & -- & -- & -- & -- & -- & 1 \\
\hline $\mathrm{CH}-2440$ & $8 / 17 / 81$ & .02 & -- & -- & -- & -- & -- & 1 \\
\hline $\mathrm{CH}-2459$ & $8 / 4 / 82$ & -- & -- & -- & -- & -- & -- & 1 \\
\hline $\mathrm{CH}-2460$ & $8 / 4 / 82$ & -- & -- & -- & -- & -- & -- & 1 \\
\hline $\mathrm{CH}-2461$ & $8 / 4 / 82$ & -- & -- & -- & -- & -- & -- & 1 \\
\hline $\mathrm{CH}-2461$ & $7 / 7 / 83$ & .01 & -- & -- & -- & -- & -- & -- \\
\hline $\mathrm{CH}-2461$ & $8 / 8 / 95$ & $<.015$ & -- & $<.010$ & $<.010$ & -- & -- & $<1.0$ \\
\hline $\mathrm{CH}-2673$ & $8 / 6 / 85$ & .08 & -- & -- & -- & -- & -- & $<1.0$ \\
\hline $\mathrm{CH}-2678$ & 8/28/84 & $<.010$ & -- & -- & -- & 10 & -- & $<1.0$ \\
\hline $\mathrm{CH}-2678$ & $6 / 25 / 85$ & -- & -- & -- & -- & $<10$ & -- & 1 \\
\hline $\mathrm{CH}-3316$ & $8 / 8 / 88$ & .02 & -- & -- & -- & -- & -- & \\
\hline $\mathrm{CH}-3316$ & $9 / 6 / 90$ & .01 & -- & -- & -- & -- & -- & $<1.0$ \\
\hline $\mathrm{CH}-3317$ & 8/8/88 & $<.010$ & -- & -- & -- & -- & -- & -- \\
\hline $\mathrm{CH}-4118$ & $7 / 8 / 91$ & $<.010$ & -- & -- & $<.010$ & -- & -- & -- \\
\hline $\mathrm{CH}-4126$ & $8 / 7 / 91$ & .02 & -- & -- & $<.010$ & -- & -- & -- \\
\hline $\mathrm{CH}-4275$ & 9/9/92 & .08 & -- & -- & $<.010$ & -- & -- & $<1.0$ \\
\hline
\end{tabular}


Table 20. Results of field determinations and laboratory analyses for selected inorganic constituents, Big Elk Creek Basin, Pennsylvania and Maryland-Continued

\begin{tabular}{|c|c|c|c|c|c|c|c|c|}
\hline $\begin{array}{l}\text { Well- } \\
\text { identification } \\
\text { number }\end{array}$ & $\begin{array}{c}\text { Sample } \\
\text { date }\end{array}$ & $\begin{array}{c}\text { Barium, } \\
\text { dissolved } \\
(\mu \mathrm{g} / \mathrm{L} \text { as } \mathrm{Ba})\end{array}$ & $\begin{array}{c}\text { Boron, } \\
\text { dissolved } \\
(\mu \mathrm{g} / \mathrm{L} \text { as } \\
\text { B) }\end{array}$ & $\begin{array}{c}\text { Cad- } \\
\text { mium, } \\
\text { dissolved } \\
(\mu \mathrm{g} / \mathrm{L} \text { as } \mathrm{Cd})\end{array}$ & $\begin{array}{l}\text { Chromium, } \\
\text { dissolved } \\
(\mu \mathrm{g} / \mathrm{L} \text { as Cr) }\end{array}$ & $\begin{array}{c}\text { Cobalt, } \\
\text { dissolved } \\
(\mu \mathrm{g} / \mathrm{L} \text { as Co })\end{array}$ & $\begin{array}{c}\text { Copper, } \\
\text { dissolved } \\
(\mu \mathrm{g} / \mathrm{L} \text { as } \mathrm{Cu})\end{array}$ & $\begin{array}{c}\text { Iron, } \\
\text { dissolved } \\
(\mu \mathrm{g} / \mathrm{L} \text { as } \mathrm{Fe})\end{array}$ \\
\hline $\mathrm{CH}-75$ & $7 / 14 / 86$ & -- & -- & -- & -- & -- & -- & -- \\
\hline $\mathrm{CH}-75$ & $8 / 23 / 90$ & -- & -- & 8 & $<1.0$ & -- & 26 & 10 \\
\hline $\mathrm{CH}-75$ & $8 / 8 / 00$ & -- & $<16$ & -- & -- & -- & -- & 60 \\
\hline $\mathrm{CH}-525$ & $9 / 21 / 25$ & -- & -- & -- & -- & -- & -- & 110 \\
\hline $\mathrm{CH}-526$ & $9 / 21 / 25$ & -- & -- & -- & -- & -- & -- & 410 \\
\hline $\mathrm{CH}-528$ & $9 / 21 / 25$ & -- & -- & -- & -- & -- & -- & 60 \\
\hline $\mathrm{CH}-1702$ & $10 / 14 / 74$ & $<100$ & $<20$ & ND & ND & ND & $<20$ & 120 \\
\hline $\mathrm{CH}-1703$ & $8 / 5 / 91$ & -- & -- & -- & -- & -- & -- & 20 \\
\hline $\mathrm{CH}-1720$ & 10/1/92 & -- & -- & $<1.0$ & $<1.0$ & -- & 18 & 40 \\
\hline $\mathrm{CH}-1720$ & $4 / 6 / 93$ & -- & -- & -- & -- & -- & -- & 80 \\
\hline $\mathrm{CH}-1720$ & 6/10/93 & -- & -- & -- & -- & -- & -- & 50 \\
\hline $\mathrm{CH}-1720$ & 9/16/93 & -- & -- & -- & -- & -- & -- & $<10$ \\
\hline $\mathrm{CH}-1724$ & $10 / 14 / 74$ & $<100$ & $<20$ & ND & ND & ND & 110 & 20 \\
\hline $\mathrm{CH}-1735$ & $9 / 6 / 00$ & -- & 16 & -- & -- & -- & -- & $<10$ \\
\hline $\mathrm{CH}-1737$ & 7/11/91 & -- & -- & -- & -- & -- & -- & 30 \\
\hline $\mathrm{CH}-1761$ & 8/22/91 & -- & -- & -- & -- & -- & -- & $<1$ \\
\hline $\mathrm{CH}-1765$ & $8 / 22 / 91$ & -- & -- & -- & -- & -- & -- & $<1$ \\
\hline $\mathrm{CH}-1770$ & $10 / 15 / 74$ & $<100$ & $<20$ & $<2.0$ & ND & ND & 40 & 80 \\
\hline $\mathrm{CH}-1776$ & $10 / 15 / 74$ & $<100$ & $<20$ & ND & ND & ND & ND & 50 \\
\hline $\mathrm{CH}-1777$ & $8 / 1 / 74$ & -- & -- & -- & -- & -- & -- & 1,970 \\
\hline $\mathrm{CH}-1778$ & 1/14/71 & -- & -- & -- & -- & -- & -- & 400 \\
\hline $\mathrm{CH}-1783$ & $10 / 15 / 74$ & $<100$ & $<20$ & ND & ND & ND & ND & 20 \\
\hline $\mathrm{CH}-1829$ & $8 / 31 / 95$ & -- & -- & -- & -- & -- & -- & -- \\
\hline $\mathrm{CH}-1835$ & $10 / 14 / 74$ & $<100$ & $<20$ & ND & ND & ND & 90 & 20 \\
\hline $\mathrm{CH}-1996$ & 2/27/74 & -- & -- & -- & -- & -- & -- & 390 \\
\hline $\mathrm{CH}-2186$ & 8/18/93 & 13 & -- & $<1.0$ & $<5.0$ & $<3$ & $<10$ & 10 \\
\hline $\mathrm{CH}-2439$ & $8 / 17 / 81$ & -- & -- & $<1.0$ & $<1.0$ & -- & -- & $<10$ \\
\hline $\mathrm{CH}-2440$ & $8 / 17 / 81$ & -- & -- & $<1.0$ & $<1.0$ & -- & -- & 30 \\
\hline $\mathrm{CH}-2459$ & $8 / 4 / 82$ & -- & -- & 1 & $<1.0$ & -- & 20 & -- \\
\hline $\mathrm{CH}-2460$ & $8 / 4 / 82$ & -- & -- & $<1.0$ & $<1.0$ & -- & 33 & $<1$ \\
\hline $\mathrm{CH}-2461$ & $8 / 4 / 82$ & -- & -- & $<1.0$ & $<1.0$ & -- & 6 & $<1$ \\
\hline $\mathrm{CH}-2461$ & 7/7/83 & -- & -- & -- & -- & -- & -- & -- \\
\hline $\mathrm{CH}-2461$ & $8 / 8 / 95$ & 52 & -- & $<1.0$ & $<5.0$ & $<3$ & $<10$ & 10 \\
\hline $\mathrm{CH}-2673$ & $8 / 6 / 85$ & & -- & $<1.0$ & 3 & -- & 58 & 90 \\
\hline CH-2678 & 8/28/84 & $<100$ & $<20$ & 1 & $<10.0$ & -- & 2 & 20 \\
\hline CH-2678 & $6 / 25 / 85$ & 72 & $<20$ & $<1.0$ & 10 & -- & 4 & 10 \\
\hline $\mathrm{CH}-3316$ & 8/8/88 & -- & -- & -- & -- & -- & -- & -- \\
\hline $\mathrm{CH}-3316$ & $9 / 6 / 90$ & -- & -- & 1 & $<1.0$ & -- & 1 & 3,400 \\
\hline $\mathrm{CH}-3317$ & 8/8/88 & -- & -- & -- & -- & -- & -- & -- \\
\hline $\mathrm{CH}-4118$ & 7/8/91 & -- & -- & -- & -- & -- & -- & 20 \\
\hline $\mathrm{CH}-4126$ & $8 / 7 / 91$ & -- & -- & -- & -- & -- & -- & 10 \\
\hline $\mathrm{CH}-4275$ & 9/9/92 & -- & -- & $<1.0$ & $<1.0$ & -- & 17 & 80 \\
\hline
\end{tabular}


Table 20. Results of field determinations and laboratory analyses for selected inorganic constituents,

Big Elk Creek Basin, Pennsylvania and Maryland-Continued

\begin{tabular}{|c|c|c|c|c|c|c|c|c|c|}
\hline $\begin{array}{c}\text { Well- } \\
\text { identification } \\
\text { number }\end{array}$ & $\begin{array}{l}\text { Sample } \\
\text { date }\end{array}$ & $\begin{array}{l}\text { Lead, } \\
\text { dissolved } \\
(\mu \mathrm{g} / \mathrm{L} \text { as } \\
\mathrm{Pb})\end{array}$ & $\begin{array}{c}\text { Lithium, } \\
\text { dissolved } \\
\text { ( } \mu \mathrm{g} / \mathrm{L} \text { as } \mathrm{Li})\end{array}$ & $\begin{array}{c}\text { Man- } \\
\text { ganese, } \\
\text { dissolved } \\
(\mu \mathrm{g} / \mathrm{L} \text { as } \mathrm{Mn})\end{array}$ & $\begin{array}{c}\text { Mercury, } \\
\text { dissolved } \\
(\mu \mathrm{g} / \mathrm{L} \text { as } \\
\mathrm{Hg})\end{array}$ & $\begin{array}{c}\text { Nickel, } \\
\text { dissolved } \\
(\mu \mathrm{g} / \mathrm{L} \text { as Ni) }\end{array}$ & $\begin{array}{c}\text { Selenium, } \\
\text { dissolved } \\
(\mu \mathrm{g} / \mathrm{L} \text { as } \mathrm{Se})\end{array}$ & $\begin{array}{c}\text { Silver, } \\
\text { dissolved } \\
(\mu \mathrm{g} / \mathrm{L} \text { as Ag) }\end{array}$ & $\begin{array}{c}\text { Zinc, } \\
\text { dissolved } \\
(\mu \mathrm{g} / \mathrm{L} \text { as } \\
\mathrm{Zn})\end{array}$ \\
\hline $\mathrm{CH}-75$ & $7 / 14 / 86$ & -- & -- & -- & -- & -- & -- & -- & -- \\
\hline $\mathrm{CH}-75$ & $8 / 23 / 90$ & 5 & -- & 55 & $<0.1$ & -- & -- & -- & $<3$ \\
\hline $\mathrm{CH}-75$ & $8 / 8 / 00$ & -- & -- & 103 & & -- & -- & -- & -- \\
\hline $\mathrm{CH}-525$ & $9 / 21 / 25$ & -- & -- & -- & -- & -- & -- & -- & -- \\
\hline $\mathrm{CH}-526$ & $9 / 21 / 25$ & -- & -- & -- & -- & -- & -- & -- & -- \\
\hline $\mathrm{CH}-528$ & $9 / 21 / 25$ & -- & -- & -- & -- & -- & -- & -- & -- \\
\hline $\mathrm{CH}-1702$ & $10 / 14 / 74$ & $<2$ & $<10.0$ & 80 & $<.5$ & 4 & $<2.0$ & ND & 120 \\
\hline $\mathrm{CH}-1703$ & $8 / 5 / 91$ & -- & -- & 6 & -- & -- & -- & -- & -- \\
\hline $\mathrm{CH}-1720$ & 10/1/92 & $<1$ & -- & 2 & $<.1$ & -- & -- & -- & 4 \\
\hline $\mathrm{CH}-1720$ & 4/6/93 & -- & -- & 7 & -- & -- & -- & -- & -- \\
\hline $\mathrm{CH}-1720$ & 6/10/93 & -- & -- & $<10$ & -- & -- & -- & -- & -- \\
\hline $\mathrm{CH}-1720$ & 9/16/93 & -- & -- & 20 & -- & -- & -- & -- & -- \\
\hline $\mathrm{CH}-1724$ & $10 / 14 / 74$ & $<2$ & $<10.0$ & $<10$ & $<.5$ & 3 & $<1.0$ & ND & $<20$ \\
\hline $\mathrm{CH}-1735$ & $9 / 6 / 00$ & -- & -- & 22 & -- & -- & -- & -- & -- \\
\hline $\mathrm{CH}-1737$ & $7 / 11 / 91$ & -- & -- & 41 & -- & -- & -- & -- & -- \\
\hline $\mathrm{CH}-1761$ & 8/22/91 & -- & -- & 1 & -- & -- & -- & -- & -- \\
\hline $\mathrm{CH}-1765$ & $8 / 22 / 91$ & -- & -- & 26 & -- & -- & -- & -- & -- \\
\hline $\mathrm{CH}-1770$ & $10 / 15 / 74$ & 4 & $<10.0$ & 160 & $<.5$ & 4 & $<1.0$ & ND & 1,300 \\
\hline $\mathrm{CH}-1776$ & $10 / 15 / 74$ & 2 & $<10.0$ & $<10$ & $<.5$ & 3 & 3 & ND & 220 \\
\hline $\mathrm{CH}-1777$ & $8 / 1 / 74$ & -- & -- & 40 & -- & -- & -- & -- & -- \\
\hline $\mathrm{CH}-1778$ & $1 / 14 / 71$ & -- & -- & 180 & -- & -- & -- & -- & -- \\
\hline $\mathrm{CH}-1783$ & $10 / 15 / 74$ & 2 & $<10.0$ & $<10$ & $<.5$ & $<2$ & 2 & ND & 30 \\
\hline $\mathrm{CH}-1829$ & $8 / 31 / 95$ & -- & -- & -- & -- & -- & -- & -- & -- \\
\hline $\mathrm{CH}-1835$ & $10 / 14 / 74$ & 3 & $<10.0$ & $<10$ & $<.5$ & 8 & 2 & ND & 20 \\
\hline $\mathrm{CH}-1996$ & $2 / 27 / 74$ & -- & -- & 40 & -- & -- & -- & -- & -- \\
\hline $\mathrm{CH}-2186$ & 8/18/93 & $<10$ & 9 & 27 & -- & $<10$ & -- & $<1$ & 33 \\
\hline $\mathrm{CH}-2439$ & $8 / 17 / 81$ & $<1$ & -- & 3 & $<.1$ & 3 & -- & -- & -- \\
\hline $\mathrm{CH}-2440$ & $8 / 17 / 81$ & 1 & -- & 3 & $<.1$ & 3 & -- & -- & -- \\
\hline $\mathrm{CH}-2459$ & $8 / 4 / 82$ & 1 & -- & 3 & $<.1$ & $<1$ & $<1.0$ & -- & 68 \\
\hline $\mathrm{CH}-2460$ & $8 / 4 / 82$ & 2 & -- & 20 & $<.1$ & 2 & $<1.0$ & -- & 13 \\
\hline $\mathrm{CH}-2461$ & $8 / 4 / 82$ & 1 & -- & 5 & $<.1$ & 1 & $<1.0$ & -- & $<4$ \\
\hline $\mathrm{CH}-2461$ & $7 / 7 / 83$ & -- & -- & -- & -- & -- & -- & -- & -- \\
\hline $\mathrm{CH}-2461$ & $8 / 8 / 95$ & 10 & 8 & 3 & $<.1$ & $<10$ & -- & $<1$ & $<3$ \\
\hline CH-2673 & $8 / 6 / 85$ & 1 & -- & 110 & $<.1$ & 5 & $<1.0$ & -- & 80 \\
\hline CH-2678 & 8/28/84 & 1 & 10 & 10 & $<.1$ & & -- & -- & 20 \\
\hline $\mathrm{CH}-2678$ & $6 / 25 / 85$ & 4 & 10 & 23 & $<.1$ & $<1$ & -- & -- & 27 \\
\hline $\mathrm{CH}-3316$ & 8/8/88 & -- & -- & -- & -- & -- & -- & -- & -- \\
\hline $\mathrm{CH}-3316$ & $9 / 6 / 90$ & $<1$ & & 330 & $<.1$ & -- & -- & -- & $<3$ \\
\hline CH-3317 & $8 / 8 / 88$ & -- & -- & -- & -- & -- & -- & -- & -- \\
\hline $\mathrm{CH}-4118$ & $7 / 8 / 91$ & -- & -- & 11 & -- & -- & -- & -- & -- \\
\hline $\mathrm{CH}-4126$ & $8 / 7 / 91$ & -- & -- & $<10$ & -- & -- & -- & -- & -- \\
\hline $\mathrm{CH}-4275$ & 9/9/92 & $<1$ & & 36 & $<.1$ & -- & -- & -- & $<3$ \\
\hline
\end{tabular}


Table 20. Results of field determinations and laboratory analyses for selected inorganic constituents, Big Elk Creek Basin, Pennsylvania and Maryland-Continued

\begin{tabular}{|c|c|c|c|c|c|c|c|}
\hline $\begin{array}{c}\text { Well- } \\
\text { identification } \\
\text { number }\end{array}$ & $\begin{array}{c}\text { Geologic } \\
\text { unit }\end{array}$ & $\begin{array}{c}\text { Sample } \\
\text { date }\end{array}$ & $\begin{array}{c}\text { Dissolved } \\
\text { oxygen } \\
\text { (mg/L) }\end{array}$ & $\begin{array}{c}\text { pH } \\
\text { (standard } \\
\text { units) }\end{array}$ & $\begin{array}{c}\text { Specific } \\
\text { conduc- } \\
\text { tance } \\
(\mu \mathrm{S} / \mathrm{cm})\end{array}$ & $\begin{array}{c}\text { Alkalinity } \\
(\mathrm{mg} / \mathrm{L} \text { as } \\
\left.\mathrm{CaCO}_{3}\right)\end{array}$ & $\begin{array}{c}\text { Water } \\
\text { temperature } \\
\left({ }^{\circ} \mathrm{C}\right)\end{array}$ \\
\hline $\mathrm{CH}-4297$ & 300WSCK & $10 / 1 / 92$ & 7.2 & 6.2 & 228 & 22 & 13.5 \\
\hline $\mathrm{CH}-4806$ & 300WSCK & 6/28/94 & 9.4 & 5.7 & 248 & 26 & 12 \\
\hline $\mathrm{CH}-4931$ & 300WSCK & 7/21/94 & 10 & 5.3 & 74 & 6 & 12.9 \\
\hline $\mathrm{CH}-4933$ & 300WSCK & $7 / 14 / 94$ & 8.9 & 7.4 & 106 & 16 & 14.7 \\
\hline $\mathrm{CH}-5231$ & 300WSCK & 8/14/95 & 9 & 5.8 & 161 & 20 & 13 \\
\hline $\mathrm{CH}-5420$ & 300WSCK & 6/9/98 & -- & 6.1 & 179 & -- & 14.3 \\
\hline $\mathrm{CH}-5421$ & 300WSCK & 6/10/98 & -- & 6.3 & 173 & -- & -- \\
\hline $\mathrm{CH}-5423$ & 300WSCK & 6/16/98 & -- & 5.2 & 162 & -- & 14.3 \\
\hline $\mathrm{CH}-5424$ & 300WSCK & 6/24/98 & -- & 5.7 & 85 & -- & 13.6 \\
\hline $\mathrm{CH}-5425$ & 300PRCK & 7/1/98 & -- & 7.1 & 191 & -- & 15.5 \\
\hline $\mathrm{CH}-5426$ & 300WSCK & $11 / 5 / 98$ & -- & 6.8 & 81 & -- & 13.2 \\
\hline $\mathrm{CH}-5428$ & 300WSCK & $11 / 3 / 98$ & -- & 7.4 & 131 & -- & 14.6 \\
\hline $\mathrm{CH}-5430$ & 300WSCK & 7/7/98 & 6.5 & 5.3 & 374 & -- & 18.1 \\
\hline $\mathrm{CH}-5431$ & 300WSCK & 7/7/98 & -- & 7.1 & 126 & -- & 14.1 \\
\hline $\mathrm{CH}-5432$ & 000SRPN & 7/14/98 & -- & 7.8 & 410 & -- & 13.7 \\
\hline $\mathrm{CH}-5433$ & 300WSCK & 7/14/98 & -- & 5.9 & 169 & -- & 16.5 \\
\hline $\mathrm{CH}-5434$ & 300WSCK & 7/15/98 & -- & 6.0 & 89 & -- & 14.6 \\
\hline CH-5437 & 300WSCK & $11 / 18 / 98$ & -- & 6.0 & 154 & -- & 14.0 \\
\hline CH-5439 & O00SRPN & $11 / 16 / 98$ & -- & 8.3 & 396 & -- & 18.1 \\
\hline $\mathrm{CH}-5440$ & 300WSCK & $11 / 4 / 98$ & -- & -- & 134 & -- & 12.2 \\
\hline $\mathrm{CH}-5442$ & 300WSCK & $11 / 24 / 98$ & 6.9 & 5.8 & 88 & -- & 12.5 \\
\hline $\mathrm{CH}-5443$ & 300WSCK & $11 / 12 / 98$ & 7.5 & 6.4 & 284 & -- & 13.2 \\
\hline $\mathrm{CH}-5450$ & 000PGMT & $9 / 11 / 00$ & .2 & 6.9 & 101 & -- & 13.3 \\
\hline $\mathrm{CH}-5470$ & 300PRCK & 8/22/96 & 9.3 & 5.4 & 54 & -- & 13.5 \\
\hline $\mathrm{CH}-5476$ & 300WSCK & $9 / 4 / 96$ & 3.4 & 6.8 & 158 & 44 & 13 \\
\hline CH-5477 & 300WSCK & $9 / 4 / 96$ & 7.1 & 5.9 & 126 & 23 & 12.5 \\
\hline CH-5479 & 300WSCK & $9 / 5 / 96$ & 6.7 & 6 & 82 & -- & 13.5 \\
\hline CE Ae 8 & 300MGCK & $10 / 28 / 98$ & -- & -- & 128 & -- & 12.9 \\
\hline CE Ae 9 & 300MGCK & $10 / 26 / 98$ & -- & 6 & 784 & -- & 12.9 \\
\hline CE Ae 13 & 300MGCK & 12/3/98 & -- & 6.6 & 699 & -- & 13.2 \\
\hline CE Bf 77 & $300 U F G B$ & 3/31/83 & -- & 8.1 & 242 & -- & 13 \\
\hline
\end{tabular}


Table 20. Results of field determinations and laboratory analyses for selected inorganic constituents, Big Elk Creek Basin, Pennsylvania and Maryland-Continued

\begin{tabular}{|c|c|c|c|c|c|c|c|c|}
\hline $\begin{array}{c}\text { Well- } \\
\text { identification } \\
\text { number }\end{array}$ & $\begin{array}{c}\text { Sample } \\
\text { date }\end{array}$ & $\begin{array}{c}\text { Total } \\
\text { hardness } \\
(\mathrm{mg} / \mathrm{L} \text { as } \\
\left.\mathrm{CaCO}_{3}\right)\end{array}$ & $\begin{array}{c}\text { Calcium, } \\
\text { dissolved } \\
(\mathrm{mg} / \mathrm{L} \\
\text { as Ca) }\end{array}$ & $\begin{array}{c}\text { Magnesium, } \\
\text { dissolved } \\
(\mathrm{mg} / \mathrm{L} \\
\text { as } \mathrm{Mg})\end{array}$ & $\begin{array}{c}\text { Potassium, } \\
\text { dissolved } \\
(\mathrm{mg} / \mathrm{L} \\
\text { as K) }\end{array}$ & $\begin{array}{c}\text { Sodium, } \\
\text { dissolved } \\
(\mathrm{mg} / \mathrm{L} \\
\text { as } \mathrm{Na})\end{array}$ & $\begin{array}{l}\text { Chloride, } \\
\text { dissolved } \\
\text { (mg/L } \\
\text { as } \mathrm{Cl})\end{array}$ & $\begin{array}{c}\text { Fluoride, } \\
\text { dissolved } \\
\text { (mg/L } \\
\text { as F) }\end{array}$ \\
\hline $\mathrm{CH}-4297$ & $10 / 1 / 92$ & -- & -- & -- & -- & -- & 20 & $<0.1$ \\
\hline $\mathrm{CH}-4806$ & 6/28/94 & 65 & 14 & 7.1 & 3.3 & 11 & 29 & $<.1$ \\
\hline $\mathrm{CH}-4931$ & 7/21/94 & 20 & 2.8 & 3.1 & 1.7 & 3.3 & 6.5 & $<.1$ \\
\hline $\mathrm{CH}-4933$ & $7 / 14 / 94$ & 28 & 5.6 & 3.4 & 1.4 & 6.6 & 6.7 & $<.1$ \\
\hline $\mathrm{CH}-5231$ & 8/14/95 & -- & -- & -- & -- & -- & 14 & -- \\
\hline $\mathrm{CH}-5420$ & 6/9/98 & 56 & 7.7 & 8.84 & 1 & 8.6 & 12.5 & $<.1$ \\
\hline $\mathrm{CH}-5421$ & 6/10/98 & 59 & 15.6 & 4.88 & 2.8 & 6.8 & 10.6 & $<.1$ \\
\hline $\mathrm{CH}-5423$ & 6/16/98 & 53 & 8.34 & 7.8 & 2.1 & 4.6 & 13.6 & $<.1$ \\
\hline $\mathrm{CH}-5424$ & 6/24/98 & 22 & 4.89 & 2.36 & 2.1 & 5.1 & 4.7 & $<.1$ \\
\hline CH-5425 & $7 / 1 / 98$ & 80 & 27.1 & 3.08 & 1.8 & 5.8 & 4.1 & .1 \\
\hline $\mathrm{CH}-5426$ & $11 / 5 / 98$ & 18 & 3.26 & 2.36 & .9 & 7.7 & 3.9 & $<.1$ \\
\hline CH-5428 & 11/3/98 & 47 & 13.5 & 3.3 & 1.6 & 6 & 6.2 & $<.1$ \\
\hline $\mathrm{CH}-5430$ & $7 / 7 / 98$ & 94 & 15.5 & 13.2 & 2.2 & 28.8 & 69.7 & $<.1$ \\
\hline $\mathrm{CH}-5431$ & $7 / 7 / 98$ & 38 & 10.1 & 3.07 & 1.9 & 8.2 & 3.4 & .2 \\
\hline $\mathrm{CH}-5432$ & 7/14/98 & 230 & 4.55 & 54.1 & .1 & 1.5 & 4.9 & $<.1$ \\
\hline $\mathrm{CH}-5433$ & 7/14/98 & 47 & 12.4 & 3.87 & 2.5 & 9.2 & 13 & $<.1$ \\
\hline CH-5434 & 7/15/98 & 23 & 5.8 & 2.1 & 1.7 & 6.6 & 3.2 & $<.1$ \\
\hline CH-5437 & $11 / 18 / 98$ & 48 & 10.2 & 5.49 & 2.6 & 5.6 & 16.4 & $<.1$ \\
\hline CH-5439 & $11 / 16 / 98$ & 220 & 1.8 & 53 & .2 & 3.4 & 5.3 & $<.1$ \\
\hline $\mathrm{CH}-5440$ & $11 / 4 / 98$ & 41 & 11.7 & 2.79 & 1.6 & 11.6 & 2.8 & .2 \\
\hline CH-5442 & $11 / 24 / 98$ & 22 & 5.23 & 2.06 & 1.3 & 6.8 & 5.7 & $<.1$ \\
\hline $\mathrm{CH}-5443$ & $11 / 12 / 98$ & 99 & 23.4 & 9.73 & 1.9 & 10.1 & 38.9 & $<.1$ \\
\hline $\mathrm{CH}-5450$ & $9 / 11 / 00$ & 24 & 5.53 & 2.54 & 1.8 & 8.1 & 2.6 & .2 \\
\hline $\mathrm{CH}-5470$ & 8/22/96 & 13 & 2.9 & 1.5 & .8 & 4.5 & 3.7 & $<.1$ \\
\hline $\mathrm{CH}-5476$ & $9 / 4 / 96$ & 49 & 14 & 3.4 & 1.7 & 10 & 4.7 & .5 \\
\hline $\mathrm{CH}-5477$ & $9 / 4 / 96$ & 37 & 8.4 & 3.9 & 1.7 & 5.9 & 7.5 & $<.1$ \\
\hline CH-5479 & $9 / 5 / 96$ & 21 & 5.5 & 1.7 & 1.7 & 6.6 & 4 & $<.1$ \\
\hline CE Ae 8 & $10 / 28 / 98$ & 42 & 13.3 & 2.17 & 2.1 & 7.6 & 3.3 & $<.1$ \\
\hline CE Ae 9 & $10 / 26 / 98$ & 270 & 47.9 & 37.4 & 1.3 & 38.8 & 218 & $<.1$ \\
\hline CE Ae 13 & 12/3/98 & 320 & 66.1 & 36.7 & 1 & 19.4 & 113 & $<.1$ \\
\hline CE Bf 77 & 3/31/83 & -- & 18 & 5.8 & 3.6 & 23 & 15 & $<.1$ \\
\hline
\end{tabular}


Table 20. Results of field determinations and laboratory analyses for selected inorganic constituents, Big Elk Creek Basin, Pennsylvania and Maryland-Continued

\begin{tabular}{|c|c|c|c|c|c|c|c|c|}
\hline $\begin{array}{c}\text { Well- } \\
\text { identification } \\
\text { number }\end{array}$ & $\begin{array}{c}\text { Sample } \\
\text { date }\end{array}$ & $\begin{array}{c}\text { Silica, } \\
\text { dissolved } \\
(\mathrm{mg} / \mathrm{L} \\
\left.\text { as } \mathrm{SiO}_{2}\right)\end{array}$ & $\begin{array}{c}\text { Sulfate, } \\
\text { dissolved } \\
\left(\mathrm{mg} / \mathrm{L} \text { as } \mathrm{SO}_{4}\right)\end{array}$ & $\begin{array}{c}\text { Solids, } \\
\text { residue at } 180^{\circ} \mathrm{C}, \\
\text { dissolved } \\
(\mathrm{mg} / \mathrm{L})\end{array}$ & $\begin{array}{l}\text { Radon-222, } \\
\text { dissolved } \\
(\mathrm{pCi} / \mathrm{L})\end{array}$ & $\begin{array}{c}\mathrm{NO}_{2}+\mathrm{NO}_{3} \\
\text { dissolved } \\
(\mathrm{mg} / \mathrm{L} \text { as } \mathrm{N})\end{array}$ & $\begin{array}{c}\text { Nitrogen } \\
\text { nitrate, } \\
\text { dissolved } \\
\text { (mg/L as } \mathrm{N})\end{array}$ & $\begin{array}{c}\text { Nitrogen } \\
\text { nitrite, } \\
\text { dissolved } \\
\text { (mg/L as } \mathrm{N} \text { ) }\end{array}$ \\
\hline $\mathrm{CH}-4297$ & $10 / 1 / 92$ & -- & 4.3 & 145 & 3,300 & 11 & 11 & 0.01 \\
\hline $\mathrm{CH}-4806$ & 6/28/94 & 19 & .1 & -- & 5,800 & 12 & -- & $<.010$ \\
\hline $\mathrm{CH}-4931$ & 7/21/94 & 9.5 & 1.5 & 57 & 2,000 & 4.6 & -- & $<.010$ \\
\hline $\mathrm{CH}-4933$ & $7 / 14 / 94$ & 22 & 1 & 81 & 3,500 & -- & -- & $<.010$ \\
\hline $\mathrm{CH}-5231$ & 8/14/95 & -- & -- & -- & 2,200 & 7.1 & -- & $<.010$ \\
\hline $\mathrm{CH}-5420$ & 6/9/98 & 18 & 8.6 & 117 & 2,800 & 6.33 & 6.32 & .011 \\
\hline $\mathrm{CH}-5421$ & 6/10/98 & 18.8 & 9.4 & 117 & 2,100 & 3.41 & 3.4 & .01 \\
\hline $\mathrm{CH}-5423$ & 6/16/98 & 11.9 & 2.2 & 112 & 3,700 & -- & -- & -- \\
\hline $\mathrm{CH}-5424$ & 6/24/98 & 17.3 & 2 & 69 & 2,000 & 3.55 & -- & $<.010$ \\
\hline $\mathrm{CH}-5425$ & $7 / 1 / 98$ & 23.9 & 18.2 & 127 & 5,300 & $<.050$ & -- & $<.010$ \\
\hline $\mathrm{CH}-5426$ & $11 / 5 / 98$ & 21.8 & .5 & 78 & 936 & 4.23 & -- & $<.010$ \\
\hline $\mathrm{CH}-5428$ & 11/3/98 & 16.6 & 8.5 & 90 & 1,600 & .38 & -- & $<.010$ \\
\hline $\mathrm{CH}-5430$ & 7/7/98 & 13.8 & 19.1 & 212 & 1,700 & 6.96 & -- & $<.010$ \\
\hline $\mathrm{CH}-5431$ & 7/7/98 & 29.6 & 11.9 & 80 & 586 & .08 & -- & $<.010$ \\
\hline $\mathrm{CH}-5432$ & $7 / 14 / 98$ & 46.8 & 8.8 & 249 & 392 & .403 & .392 & .011 \\
\hline $\mathrm{CH}-5433$ & $7 / 14 / 98$ & 25.3 & 20.6 & 114 & 9,800 & 2.31 & 2.3 & .011 \\
\hline $\mathrm{CH}-5434$ & 7/15/98 & 30.4 & 1.3 & 82 & 2,500 & 3.4 & 3.38 & .012 \\
\hline $\mathrm{CH}-5437$ & $11 / 18 / 98$ & 13.4 & .4 & 133 & 5,100 & 7.91 & -- & $<.010$ \\
\hline $\mathrm{CH}-5439$ & $11 / 16 / 98$ & 5.3 & 6.8 & 230 & 42 & .147 & .134 & .013 \\
\hline $\mathrm{CH}-5440$ & $11 / 4 / 98$ & 22.7 & 5.9 & 98 & 285 & $<.050$ & -- & $<.010$ \\
\hline $\mathrm{CH}-5442$ & $11 / 24 / 98$ & 21.4 & .1 & 82 & 2,400 & 2.79 & -- & $<.010$ \\
\hline $\mathrm{CH}-5443$ & $11 / 12 / 98$ & 26.1 & 13.2 & 231 & 980 & 6.36 & 6.35 & .011 \\
\hline $\mathrm{CH}-5450$ & $9 / 11 / 00$ & 29.6 & 7.9 & -- & 311 & $<.050$ & & $<.010$ \\
\hline $\mathrm{CH}-5470$ & 8/22/96 & 12 & $<.1$ & -- & 4,300 & 3.8 & -- & $<.010$ \\
\hline $\mathrm{CH}-5476$ & $9 / 4 / 96$ & 16 & 8.6 & -- & 1,400 & 2.4 & -- & $<.010$ \\
\hline $\mathrm{CH}-5477$ & $9 / 4 / 96$ & 10 & .5 & -- & 2,100 & 9.3 & 9.29 & .01 \\
\hline $\mathrm{CH}-5479$ & 9/5/96 & 25 & .9 & -- & 3,700 & 2.6 & -- & $<.010$ \\
\hline $\mathrm{CE}$ Ae 8 & $10 / 28 / 98$ & 28 & 13.6 & 102 & 1,200 & $<.050$ & -- & $<.010$ \\
\hline CE Ae 9 & $10 / 26 / 98$ & 28.9 & 10.1 & 599 & 2,390 & 2.31 & -- & $<.010$ \\
\hline $\mathrm{CE}$ Ae 13 & 12/3/98 & 34 & 20.3 & 457 & 528 & 2.9 & -- & $<.010$ \\
\hline CE Bf 77 & 3/31/83 & 18 & 6.2 & 145 & -- & $<.1$ & -- & -- \\
\hline
\end{tabular}


Table 20. Results of field determinations and laboratory analyses for selected inorganic constituents, Big Elk Creek Basin, Pennsylvania and Maryland-Continued

\begin{tabular}{|c|c|c|c|c|c|c|c|c|}
\hline $\begin{array}{c}\text { Well- } \\
\text { identification } \\
\text { number }\end{array}$ & $\begin{array}{c}\text { Sample } \\
\text { date }\end{array}$ & $\begin{array}{c}\text { Nitrogen } \\
\text { ammonia, } \\
\text { dissolved } \\
\text { (mg/L as N) }\end{array}$ & $\begin{array}{c}\text { Phosphate, } \\
\text { ortho, } \\
\text { dissolved } \\
\left(\mathrm{mg} / \mathrm{L} \text { as } \mathrm{PO}_{4}\right)\end{array}$ & $\begin{array}{l}\text { Phosphorus, } \\
\text { dissolved } \\
\text { (mg/L as P) }\end{array}$ & $\begin{array}{l}\text { Phosphate, } \\
\text { ortho, } \\
\text { dissolved } \\
\text { (mg/L as P) }\end{array}$ & $\begin{array}{l}\text { Aluminum, } \\
\text { dissolved } \\
\text { ( } \mu \mathrm{g} / \mathrm{L} \text { as } \mathrm{Al})\end{array}$ & $\begin{array}{l}\text { Antimony, } \\
\text { dissolved } \\
(\mu \mathrm{g} / \mathrm{L} \text { as Sb) }\end{array}$ & $\begin{array}{c}\text { Arsenic, } \\
\text { dissolved } \\
(\mu \mathrm{g} / \mathrm{L} \text { as As })\end{array}$ \\
\hline $\mathrm{CH}-4297$ & $10 / 1 / 92$ & 0.02 & 0.061 & -- & 0.02 & -- & -- & -- \\
\hline $\mathrm{CH}-4806$ & 6/28/94 & .01 & .061 & -- & .02 & -- & -- & -- \\
\hline $\mathrm{CH}-4931$ & $7 / 21 / 94$ & .03 & -- & $<0.010$ & $<.010$ & -- & -- & -- \\
\hline $\mathrm{CH}-4933$ & $7 / 14 / 94$ & $<.010$ & .184 & .08 & .06 & -- & -- & -- \\
\hline $\mathrm{CH}-5231$ & 8/14/95 & .05 & -- & -- & $<.010$ & -- & -- & -- \\
\hline $\mathrm{CH}-5420$ & $6 / 9 / 98$ & .034 & .172 & .016 & .056 & -- & -- & $<1.0$ \\
\hline $\mathrm{CH}-5421$ & 6/10/98 & .035 & -- & $<.010$ & $<.010$ & -- & -- & $<1.0$ \\
\hline $\mathrm{CH}-5423$ & 6/16/98 & -- & -- & -- & -- & -- & -- & $<1.0$ \\
\hline $\mathrm{CH}-5424$ & 6/24/98 & .022 & .037 & .018 & .012 & -- & -- & $<1.0$ \\
\hline $\mathrm{CH}-5425$ & $7 / 1 / 98$ & .022 & -- & $<.010$ & $<.010$ & -- & -- & $<1.0$ \\
\hline $\mathrm{CH}-5426$ & $11 / 5 / 98$ & $<.020$ & .251 & .073 & .082 & -- & -- & $<1.0$ \\
\hline $\mathrm{CH}-5428$ & $11 / 3 / 98$ & $<.020$ & .031 & $<.050$ & .01 & -- & -- & $<1.0$ \\
\hline $\mathrm{CH}-5430$ & 7/7/98 & $<.020$ & .061 & $<.010$ & .02 & -- & -- & $<1.0$ \\
\hline $\mathrm{CH}-5431$ & 7/7/98 & $<.020$ & .181 & .074 & .059 & -- & -- & $<1.0$ \\
\hline $\mathrm{CH}-5432$ & $7 / 14 / 98$ & .052 & .086 & $<.010$ & .028 & -- & -- & $<1.0$ \\
\hline $\mathrm{CH}-5433$ & $7 / 14 / 98$ & .057 & .178 & .105 & .058 & -- & -- & $<1.0$ \\
\hline $\mathrm{CH}-5434$ & 7/15/98 & .064 & .181 & .058 & .059 & -- & -- & $<1.0$ \\
\hline $\mathrm{CH}-5437$ & $11 / 18 / 98$ & .025 & .058 & $<.050$ & .019 & -- & -- & $<1.0$ \\
\hline $\mathrm{CH}-5439$ & $11 / 16 / 98$ & .022 & .031 & $<.050$ & .01 & -- & -- & $<1.0$ \\
\hline $\mathrm{CH}-5440$ & $11 / 4 / 98$ & .027 & .08 & $<.050$ & .026 & -- & -- & $<1.0$ \\
\hline $\mathrm{CH}-5442$ & $11 / 24 / 98$ & .021 & .034 & $<.050$ & .011 & -- & -- & $<1.0$ \\
\hline $\mathrm{CH}-5443$ & $11 / 12 / 98$ & .042 & .058 & $<.050$ & .019 & -- & -- & $<1.0$ \\
\hline $\mathrm{CH}-5450$ & $9 / 11 / 00$ & $<.020$ & .092 & -- & .03 & $<1$ & $<1$ & -- \\
\hline $\mathrm{CH}-5470$ & 8/22/96 & $<.015$ & .092 & .04 & .03 & -- & -- & $<1.0$ \\
\hline $\mathrm{CH}-5476$ & $9 / 4 / 96$ & $<.015$ & -- & .03 & $<.010$ & -- & -- & -- \\
\hline $\mathrm{CH}-5477$ & $9 / 4 / 96$ & .07 & -- & -- & $<.010$ & 5 & $<1$ & -- \\
\hline CH-5479 & 9/5/96 & $<.015$ & .276 & .07 & .09 & 3 & $<1$ & -- \\
\hline CE Ae 8 & $10 / 28 / 98$ & $<.020$ & .046 & $<.050$ & .015 & -- & -- & $<1.0$ \\
\hline CE Ae 9 & $10 / 26 / 98$ & .024 & .061 & $<.050$ & .02 & -- & -- & $<1.0$ \\
\hline CE Ae 13 & $12 / 3 / 98$ & $<.020$ & .086 & $<.050$ & .028 & -- & -- & $<1.0$ \\
\hline CE Bf 77 & $3 / 31 / 83$ & -- & -- & -- & $<.010$ & $<100$ & -- & 1 \\
\hline
\end{tabular}


Table 20. Results of field determinations and laboratory analyses for selected inorganic constituents, Big Elk Creek Basin, Pennsylvania and Maryland-Continued

\begin{tabular}{|c|c|c|c|c|c|c|c|c|}
\hline $\begin{array}{c}\text { Well- } \\
\text { identification } \\
\text { number }\end{array}$ & $\begin{array}{c}\text { Sample } \\
\text { date }\end{array}$ & $\begin{array}{c}\text { Barium, } \\
\text { dissolved } \\
(\mu \mathrm{g} / \mathrm{L} \text { as } \mathrm{Ba})\end{array}$ & $\begin{array}{c}\text { Boron, } \\
\text { dissolved } \\
(\mu \mathrm{g} / \mathrm{L} \text { as } \\
\text { B) }\end{array}$ & $\begin{array}{c}\text { Cad- } \\
\text { mium, } \\
\text { dissolved } \\
(\mu \mathrm{g} / \mathrm{L} \text { as } \mathrm{Cd})\end{array}$ & $\begin{array}{l}\text { Chromium, } \\
\text { dissolved } \\
(\mu \mathrm{g} / \mathrm{L} \text { as } \mathrm{Cr})\end{array}$ & $\begin{array}{c}\text { Cobalt, } \\
\text { dissolved } \\
(\mu \mathrm{g} / \mathrm{L} \text { as Co })\end{array}$ & $\begin{array}{c}\text { Copper, } \\
\text { dissolved } \\
(\mu \mathrm{g} / \mathrm{L} \text { as } \mathrm{Cu})\end{array}$ & $\begin{array}{c}\text { Iron, } \\
\text { dissolved } \\
(\mu \mathrm{g} / \mathrm{L} \text { as } \mathrm{Fe})\end{array}$ \\
\hline $\mathrm{CH}-4297$ & $10 / 1 / 92$ & -- & -- & & & -- & & 30 \\
\hline $\mathrm{CH}-4806$ & $6 / 28 / 94$ & 120 & -- & $<1.0$ & $<5.0$ & $<3$ & 20 & 40 \\
\hline $\mathrm{CH}-4931$ & $7 / 21 / 94$ & -- & -- & -- & -- & -- & -- & -- \\
\hline CH-4933 & $7 / 14 / 94$ & -- & -- & -- & -- & -- & -- & 10 \\
\hline $\mathrm{CH}-5231$ & $8 / 14 / 95$ & -- & -- & -- & -- & -- & -- & -- \\
\hline $\mathrm{CH}-5420$ & 6/9/98 & 2 & -- & $<8.0$ & $<14.0$ & $<12$ & $<10$ & $<10$ \\
\hline $\mathrm{CH}-5421$ & 6/10/98 & 13 & -- & $<8.0$ & $<14.0$ & $<12$ & $<10$ & $<10$ \\
\hline $\mathrm{CH}-5423$ & 6/16/98 & 75 & -- & $<8.0$ & $<14.0$ & $<12$ & 36 & $<10$ \\
\hline CH-5424 & 6/24/98 & 5 & -- & $<8.0$ & $<14.0$ & $<12$ & $<10$ & $<10$ \\
\hline $\mathrm{CH}-5425$ & $7 / 1 / 98$ & 4 & -- & $<8.0$ & $<14.0$ & $<12$ & $<10$ & 450 \\
\hline $\mathrm{CH}-5426$ & $11 / 5 / 98$ & 2 & -- & $<8.0$ & $<14.0$ & $<7$ & $9 \mathrm{E}$ & $10 \mathrm{E}$ \\
\hline CH-5428 & $11 / 3 / 98$ & 15 & -- & $<8.0$ & $<14.0$ & $<7$ & $<10$ & $10 \mathrm{E}$ \\
\hline $\mathrm{CH}-5430$ & 7/7/98 & 123 & -- & $<8.0$ & $<14.0$ & $<12$ & $<10$ & 710 \\
\hline $\mathrm{CH}-5431$ & 7/7/98 & 6 & -- & $<8.0$ & $<14.0$ & $<12$ & $<10$ & 200 \\
\hline $\mathrm{CH}-5432$ & $7 / 14 / 98$ & 1 & -- & $<8.0$ & $<14.0$ & $<12$ & $<10$ & $<10$ \\
\hline $\mathrm{CH}-5433$ & $7 / 14 / 98$ & 10 & -- & $<8.0$ & $<14.0$ & $<12$ & $<10$ & $<10$ \\
\hline $\mathrm{CH}-5434$ & $7 / 15 / 98$ & 21 & -- & $<8.0$ & $<14.0$ & $<12$ & 29 & $<10$ \\
\hline $\mathrm{CH}-5437$ & $11 / 18 / 98$ & 125 & -- & $<8.0$ & $<14.0$ & $<7$ & $7 \mathrm{E}$ & $<10$ \\
\hline CH-5439 & $11 / 16 / 98$ & 4 & -- & $<8.0$ & $<14.0$ & $<7$ & $<10$ & $<10$ \\
\hline $\mathrm{CH}-5440$ & $11 / 4 / 98$ & 14 & -- & $<8.0$ & $<14.0$ & $<7$ & $<10$ & 60 \\
\hline $\mathrm{CH}-5442$ & $11 / 24 / 98$ & 18 & -- & $<8.0$ & $<14.0$ & $<7$ & $9 \mathrm{E}$ & 120 \\
\hline $\mathrm{CH}-5443$ & $11 / 12 / 98$ & 110 & -- & $<8.0$ & $<14.0$ & $<7$ & $<10$ & 40 \\
\hline $\mathrm{CH}-5450$ & $9 / 11 / 00$ & 32 & -- & $<1.0$ & $<.8$ & $<1$ & $<1$ & 1,560 \\
\hline $\mathrm{CH}-5470$ & 8/22/96 & 17 & -- & $<1.0$ & $<5.0$ & $<3$ & 10 & $<1$ \\
\hline $\mathrm{CH}-5476$ & 9/4/96 & 16 & -- & $<1.0$ & $<5.0$ & $<3$ & $<10$ & $<1$ \\
\hline $\mathrm{CH}-5477$ & 9/4/96 & 54 & -- & $<1.0$ & $<1.0$ & $<1$ & 6 & 10 \\
\hline CH-5479 & 9/5/96 & 25 & 4 & $<1.0$ & $<1.0$ & $<1$ & 28 & 10 \\
\hline CE Ae 8 & $10 / 28 / 98$ & 14 & -- & $<8.0$ & $<14.0$ & $<7$ & $<10$ & 250 \\
\hline CE Ae 9 & $10 / 26 / 98$ & 208 & -- & $<8.0$ & 14.2 & $<7$ & $<10$ & 110 \\
\hline $\mathrm{CE} \mathrm{Ae} 13$ & $12 / 3 / 98$ & 15 & -- & $<8.0$ & $<14.0$ & $<7$ & 41 & $<10$ \\
\hline CE Bf 77 & $3 / 31 / 83$ & -- & 80 & $<1.0$ & 10 & -- & -- & 160 \\
\hline
\end{tabular}


Table 20. Results of field determinations and laboratory analyses for selected inorganic constituents, Big Elk Creek Basin, Pennsylvania and Maryland-Continued

\begin{tabular}{|c|c|c|c|c|c|c|c|c|c|}
\hline $\begin{array}{c}\text { Well- } \\
\text { identification } \\
\text { number }\end{array}$ & $\begin{array}{c}\text { Sample } \\
\text { date }\end{array}$ & $\begin{array}{c}\text { Lead, } \\
\text { dissolved } \\
(\mu \mathrm{g} / \mathrm{L} \text { as } \\
\mathrm{Pb})\end{array}$ & $\begin{array}{l}\text { Lithium, } \\
\text { dissolved } \\
(\mu \mathrm{g} / \mathrm{L} \text { as } \mathrm{Li})\end{array}$ & $\begin{array}{c}\text { Man- } \\
\text { ganese, } \\
\text { dissolved } \\
(\mu \mathrm{g} / \mathrm{L} \text { as } \mathrm{Mn})\end{array}$ & $\begin{array}{l}\text { Mercury, } \\
\text { dissolved } \\
(\mu \mathrm{g} / \mathrm{L} \text { as } \\
\mathrm{Hg})\end{array}$ & $\begin{array}{c}\text { Nickel, } \\
\text { dissolved } \\
(\mu \mathrm{g} / \mathrm{L} \text { as } \mathrm{Ni})\end{array}$ & $\begin{array}{c}\text { Selenium, } \\
\text { dissolved } \\
(\mu \mathrm{g} / \mathrm{L} \text { as } \mathrm{Se})\end{array}$ & $\begin{array}{c}\text { Silver, } \\
\text { dissolved } \\
(\mu \mathrm{g} / \mathrm{L} \text { as Ag) }\end{array}$ & $\begin{array}{c}\text { Zinc, } \\
\text { dissolved } \\
(\mu \mathrm{g} / \mathrm{L} \text { as } \\
\mathrm{Zn})\end{array}$ \\
\hline $\mathrm{CH}-4297$ & $10 / 1 / 92$ & -- & -- & 20 & -- & -- & -- & -- & -- \\
\hline $\mathrm{CH}-4806$ & 6/28/94 & 10 & 7 & 52 & -- & $<10$ & -- & $<1$ & 17 \\
\hline $\mathrm{CH}-4931$ & $7 / 21 / 94$ & -- & -- & 38 & -- & -- & -- & -- & -- \\
\hline $\mathrm{CH}-4933$ & $7 / 14 / 94$ & -- & -- & 5 & -- & -- & -- & -- & -- \\
\hline $\mathrm{CH}-5231$ & 8/14/95 & -- & -- & & -- & -- & -- & -- & -- \\
\hline $\mathrm{CH}-5420$ & 6/9/98 & $<100$ & 6.7 & 55 & -- & $<40$ & -- & $<4$ & $<20$ \\
\hline $\mathrm{CH}-5421$ & 6/10/98 & $<100$ & 7.5 & $<4$ & -- & $<40$ & -- & $<4$ & $<20$ \\
\hline $\mathrm{CH}-5423$ & 6/16/98 & $<100$ & $<4.0$ & 32 & -- & $<40$ & -- & $<4$ & $<20$ \\
\hline $\mathrm{CH}-5424$ & 6/24/98 & $<100$ & $<4.0$ & 5 & -- & $<40$ & -- & $<4$ & 40 \\
\hline $\mathrm{CH}-5425$ & $7 / 1 / 98$ & $<100$ & 6.2 & 416 & -- & $<40$ & -- & $<4$ & 24 \\
\hline $\mathrm{CH}-5426$ & $11 / 5 / 98$ & $<100$ & $5.0 \mathrm{E}$ & 11 & -- & $<40$ & -- & $<4$ & $<20$ \\
\hline $\mathrm{CH}-5428$ & 11/3/98 & $<100$ & $<6.0$ & 8 & -- & $<40$ & -- & $<4$ & $<20$ \\
\hline $\mathrm{CH}-5430$ & 7/7/98 & $<100$ & $<4.0$ & 147 & -- & $<40$ & -- & $<4$ & $<20$ \\
\hline $\mathrm{CH}-5431$ & 7/7/98 & $<100$ & 12.7 & 107 & -- & $<40$ & -- & $<4$ & $<20$ \\
\hline $\mathrm{CH}-5432$ & 7/14/98 & $<100$ & $<4.0$ & $<4$ & -- & $<40$ & -- & $<4$ & $<20$ \\
\hline $\mathrm{CH}-5433$ & $7 / 14 / 98$ & $<100$ & 8.3 & $<4$ & -- & $<40$ & -- & $<4$ & $<20$ \\
\hline $\mathrm{CH}-5434$ & 7/15/98 & $<100$ & 5 & $<4$ & -- & $<40$ & -- & $<4$ & $<20$ \\
\hline CH-5437 & 11/18/98 & $<100$ & $3.9 \mathrm{E}$ & 22 & -- & $<40$ & -- & $<4$ & $<20$ \\
\hline CH-5439 & 11/16/98 & $<100$ & $<6.0$ & $<3$ & -- & $<40$ & -- & $<4$ & $<20$ \\
\hline $\mathrm{CH}-5440$ & $11 / 4 / 98$ & $<100$ & 6.4 & 99 & -- & $<40$ & -- & $<4$ & $<20$ \\
\hline $\mathrm{CH}-5442$ & $11 / 24 / 98$ & $<100$ & $<6.0$ & 61 & -- & $<40$ & -- & $<4$ & $7 \mathrm{E}$ \\
\hline $\mathrm{CH}-5443$ & $11 / 12 / 98$ & $<100$ & 6 & 6 & -- & $<40$ & -- & $<4$ & $<20$ \\
\hline CH-5450 & $9 / 11 / 00$ & $<1$ & -- & 161 & -- & $<1$ & -- & $<1$ & 1 \\
\hline $\mathrm{CH}-5470$ & 8/22/96 & $<10$ & $<4.0$ & 16 & $<.1$ & $<10$ & -- & $<1$ & 9 \\
\hline $\mathrm{CH}-5476$ & $9 / 4 / 96$ & $<10$ & 5 & 33 & -- & $<10$ & -- & $<1$ & $<3$ \\
\hline $\mathrm{CH}-5477$ & $9 / 4 / 96$ & $<1$ & -- & 64 & -- & 4 & -- & $<1$ & 10 \\
\hline $\mathrm{CH}-5479$ & 9/5/96 & $<1$ & -- & 2 & -- & $<1$ & -- & $<1$ & 38 \\
\hline CE Ae 8 & 10/28/98 & $<100$ & 9.1 & 100 & -- & $<40$ & -- & $<4$ & $<20$ \\
\hline CE Ae 9 & 10/26/98 & $<100$ & $3.3 \mathrm{E}$ & 10 & -- & $39 \mathrm{E}$ & -- & $<4$ & $18 \mathrm{E}$ \\
\hline CE Ae 13 & $12 / 3 / 98$ & $<100$ & 6.4 & $<3$ & -- & $<40$ & -- & $<4$ & $18 \mathrm{E}$ \\
\hline CE Bf 77 & $3 / 31 / 83$ & $<10$ & -- & 10 & $<.1$ & -- & -- & -- & -- \\
\hline
\end{tabular}


Table 21. Results of laboratory analyses for pesticides in ground water, Big Elk Creek Basin, Pennsylvania and Maryland

All concentrations are given in micrograms per liter;

Date is year, month, day;

--, no data;

$<$, less than;

E, estimated concentration 
Table 21. Results of laboratory analyses for pesticides in ground water, Big Elk Creek Basin, Pennsylvania and Maryland-Continued

\begin{tabular}{|c|c|c|c|c|c|c|c|}
\hline $\begin{array}{c}\text { Well- } \\
\text { identification } \\
\text { number }\end{array}$ & $\begin{array}{l}\text { Date of } \\
\text { sample }\end{array}$ & $\begin{array}{l}\text { Acetochlor, } \\
\text { dissolved }\end{array}$ & $\begin{array}{l}\text { Alachlor, } \\
\text { dissolved }\end{array}$ & $\begin{array}{c}\text { Alachlor, } \\
\text { total }\end{array}$ & $\begin{array}{c}\text { Aldrin, } \\
\text { total }\end{array}$ & $\begin{array}{c}\text { Alpha BHC, } \\
\text { dissolved }\end{array}$ & $\begin{array}{l}\text { Ametryn, } \\
\text { dissolved }\end{array}$ \\
\hline $\mathrm{CH}-75$ & 19900823 & -- & -- & $<0.1$ & $<0.010$ & -- & -- \\
\hline $\mathrm{CH}-1720$ & 19921001 & -- & $<0.050$ & -- & -- & -- & $<0.05$ \\
\hline $\mathrm{CH}-1720$ & 19930610 & -- & -- & -- & $<.010$ & -- & -- \\
\hline $\mathrm{CH}-1735$ & 20000906 & $<0.002$ & $<.002$ & -- & -- & $<0.002$ & -- \\
\hline $\mathrm{CH}-2186$ & 19930818 & -- & $<.002$ & -- & $<.010$ & $<.002$ & -- \\
\hline $\mathrm{CH}-2439$ & 19810817 & -- & -- & -- & $<.010$ & -- & -- \\
\hline $\mathrm{CH}-2440$ & 19810817 & -- & -- & -- & $<.010$ & -- & -- \\
\hline $\mathrm{CH}-2459$ & 19820804 & -- & -- & -- & $<.010$ & -- & -- \\
\hline $\mathrm{CH}-2460$ & 19820804 & -- & -- & -- & $<.010$ & -- & -- \\
\hline $\mathrm{CH}-2461$ & 19820804 & -- & -- & -- & $<.010$ & -- & -- \\
\hline $\mathrm{CH}-2461$ & 19830707 & -- & -- & -- & & -- & -- \\
\hline $\mathrm{CH}-2461$ & 19950808 & $<.002$ & 2.49 & -- & $<.010$ & $<.002$ & -- \\
\hline $\mathrm{CH}-3316$ & 19880808 & -- & -- & $<.1$ & $<.010$ & -- & -- \\
\hline $\mathrm{CH}-3316$ & 19900906 & -- & -- & -- & -- & -- & -- \\
\hline $\mathrm{CH}-3317$ & 19880808 & -- & -- & $<.1$ & $<.010$ & -- & -- \\
\hline $\mathrm{CH}-4126$ & 19910807 & -- & $<.050$ & -- & $<.010$ & -- & $<.05$ \\
\hline $\mathrm{CH}-4297$ & 19921001 & -- & $<.050$ & -- & $<.010$ & -- & $<.05$ \\
\hline $\mathrm{CH}-4806$ & 19940628 & -- & $<.050$ & -- & $<.010$ & -- & $<.05$ \\
\hline $\mathrm{CH}-4931$ & 19940721 & $<.002$ & $<.002$ & -- & -- & $<.002$ & -- \\
\hline $\mathrm{CH}-4933$ & 19940714 & $<.002$ & $<.002$ & -- & -- & $<.002$ & -- \\
\hline $\mathrm{CH}-5420$ & 19980615 & $<.002$ & $<.002$ & -- & -- & $<.002$ & -- \\
\hline $\mathrm{CH}-5421$ & 19980615 & $<.002$ & $<.002$ & -- & -- & $<.002$ & -- \\
\hline $\mathrm{CH}-5423$ & 19980616 & $<.002$ & $<.002$ & -- & -- & $<.002$ & -- \\
\hline $\mathrm{CH}-5424$ & 19980624 & $<.002$ & $<.002$ & -- & -- & $<.002$ & -- \\
\hline $\mathrm{CH}-5425$ & 19980701 & $<.002$ & $<.002$ & -- & -- & $<.002$ & -- \\
\hline $\mathrm{CH}-5426$ & 19981105 & $<.002$ & $<.002$ & -- & -- & $<.002$ & -- \\
\hline $\mathrm{CH}-5428$ & 19981103 & $<.002$ & $<.002$ & -- & -- & $<.002$ & -- \\
\hline $\mathrm{CH}-5430$ & 19980707 & $<.002$ & $<.002$ & -- & -- & $<.002$ & -- \\
\hline $\mathrm{CH}-5431$ & 19980707 & $<.002$ & $<.002$ & -- & -- & $<.002$ & -- \\
\hline $\mathrm{CH}-5432$ & 19980714 & $<.002$ & $<.002$ & -- & -- & $<.002$ & -- \\
\hline $\mathrm{CH}-5433$ & 19980714 & $<.002$ & $<.002$ & -- & -- & $<.002$ & -- \\
\hline $\mathrm{CH}-5434$ & 19980715 & $<.002$ & $<.002$ & -- & -- & $<.002$ & -- \\
\hline $\mathrm{CH}-5437$ & 19981118 & $<.002$ & $<.002$ & -- & -- & $<.002$ & -- \\
\hline $\mathrm{CH}-5439$ & 19981116 & $<.002$ & $<.002$ & -- & -- & $<.002$ & -- \\
\hline $\mathrm{CH}-5440$ & 19981104 & $<.002$ & $<.002$ & -- & -- & $<.002$ & -- \\
\hline $\mathrm{CH}-5442$ & 19981124 & $<.002$ & $<.002$ & -- & -- & $<.002$ & -- \\
\hline $\mathrm{CH}-5443$ & 19981112 & $<.002$ & $<.002$ & -- & -- & $<.002$ & -- \\
\hline $\mathrm{CH}-5450$ & 20000911 & $<.002$ & $<.002$ & -- & -- & $<.002$ & -- \\
\hline $\mathrm{CH}-5470$ & 19960822 & $<.002$ & $<.002$ & -- & $<.010$ & $<.002$ & -- \\
\hline $\mathrm{CH}-5476$ & 19960904 & -- & -- & -- & $<.010$ & -- & -- \\
\hline $\mathrm{CH}-5477$ & 19960904 & -- & -- & -- & $<.010$ & -- & -- \\
\hline $\mathrm{CE}$ Ae 8 & 19981028 & $<.002$ & $<.002$ & -- & -- & $<.002$ & -- \\
\hline CE Ae 9 & 19981026 & $<.002$ & $<.002$ & -- & -- & $<.002$ & -- \\
\hline $\mathrm{CE} \mathrm{Ae} 13$ & 19981203 & $<.002$ & $<.002$ & -- & -- & $<.002$ & -- \\
\hline
\end{tabular}


Table 21. Results of laboratory analyses for pesticides in ground water, Big Elk Creek Basin, Pennsylvania and Maryland-Continued

\begin{tabular}{|c|c|c|c|c|c|c|c|}
\hline $\begin{array}{l}\text { Well- } \\
\text { identification } \\
\text { number }\end{array}$ & $\begin{array}{l}\text { Date of } \\
\text { sample }\end{array}$ & $\begin{array}{c}\text { Ametryne, } \\
\text { total }\end{array}$ & $\begin{array}{l}\text { Atrazine, } \\
\text { dissolved }\end{array}$ & $\begin{array}{c}\text { Atrazine } \\
\text { total }\end{array}$ & $\begin{array}{l}\text { Benfluralin, } \\
\text { total }\end{array}$ & $\begin{array}{l}\text { Butylate, } \\
\text { dissolved }\end{array}$ & $\begin{array}{l}\text { Carbaryl, } \\
\text { dissolved }\end{array}$ \\
\hline $\mathrm{CH}-75$ & 19900823 & $<0.1$ & -- & 0.1 & -- & -- & -- \\
\hline $\mathrm{CH}-1720$ & 19921001 & -- & $<0.050$ & -- & -- & -- & -- \\
\hline $\mathrm{CH}-1720$ & 19930610 & -- & -- & -- & -- & -- & -- \\
\hline $\mathrm{CH}-1735$ & 20000906 & -- & $<.004$ & -- & $<0.002$ & $<0.002$ & $<0.003$ \\
\hline CH-2186 & 19930818 & -- & $<.001$ & -- & $<.002$ & $<.002$ & $<.003$ \\
\hline $\mathrm{CH}-2439$ & 19810817 & -- & -- & -- & -- & -- & -- \\
\hline $\mathrm{CH}-2440$ & 19810817 & -- & -- & -- & -- & -- & -- \\
\hline CH-2459 & 19820804 & -- & -- & -- & -- & -- & -- \\
\hline $\mathrm{CH}-2460$ & 19820804 & -- & -- & -- & -- & -- & -- \\
\hline $\mathrm{CH}-2461$ & 19820804 & -- & -- & -- & -- & -- & -- \\
\hline $\mathrm{CH}-2461$ & 19830707 & $<.1$ & -- & .2 & -- & -- & -- \\
\hline $\mathrm{CH}-2461$ & 19950808 & -- & .172 & & $<.002$ & $<.002$ & $.015 \mathrm{E}$ \\
\hline $\mathrm{CH}-3316$ & 19880808 & $<.1$ & -- & $<.1$ & -- & -- & -- \\
\hline $\mathrm{CH}-3316$ & 19900906 & -- & -- & -- & -- & -- & -- \\
\hline $\mathrm{CH}-3317$ & 19880808 & $<.1$ & -- & $<.1$ & -- & -- & -- \\
\hline $\mathrm{CH}-4126$ & 19910807 & -- & $<.050$ & -- & -- & -- & -- \\
\hline $\mathrm{CH}-4297$ & 19921001 & -- & $<.050$ & -- & -- & -- & -- \\
\hline $\mathrm{CH}-4806$ & 19940628 & -- & $<.050$ & -- & -- & -- & -- \\
\hline $\mathrm{CH}-4931$ & 19940721 & -- & .006 & -- & $<.002$ & $<.002$ & $<.003$ \\
\hline $\mathrm{CH}-4933$ & 19940714 & -- & $<.001$ & -- & $<.002$ & $<.002$ & $<.003$ \\
\hline $\mathrm{CH}-5420$ & 19980615 & -- & .005 & -- & $<.002$ & $<.002$ & $.012 \mathrm{E}$ \\
\hline $\mathrm{CH}-5421$ & 19980615 & -- & .014 & -- & $<.002$ & $<.002$ & $<.003$ \\
\hline $\mathrm{CH}-5423$ & 19980616 & -- & .011 & -- & $<.002$ & $<.002$ & $.007 \mathrm{E}$ \\
\hline $\mathrm{CH}-5424$ & 19980624 & -- & $<.001$ & -- & $<.002$ & $<.002$ & $<.003$ \\
\hline $\mathrm{CH}-5425$ & 19980701 & -- & .01 & -- & $<.002$ & $<.002$ & $<.003$ \\
\hline $\mathrm{CH}-5426$ & 19981105 & -- & $<.001$ & -- & $<.002$ & $<.002$ & $<.003$ \\
\hline CH-5428 & 19981103 & -- & $<.001$ & -- & $<.002$ & $<.002$ & $<.003$ \\
\hline $\mathrm{CH}-5430$ & 19980707 & -- & .209 & -- & $<.002$ & $<.002$ & $.012 \mathrm{E}$ \\
\hline $\mathrm{CH}-5431$ & 19980707 & -- & $<.001$ & -- & $<.002$ & $<.002$ & $<.003$ \\
\hline $\mathrm{CH}-5432$ & 19980714 & -- & $<.001$ & -- & $<.002$ & $<.002$ & $<.003$ \\
\hline $\mathrm{CH}-5433$ & 19980714 & -- & $<.001$ & -- & $<.002$ & $<.002$ & $<.003$ \\
\hline $\mathrm{CH}-5434$ & 19980715 & -- & $<.001$ & -- & $<.002$ & $<.002$ & $<.003$ \\
\hline $\mathrm{CH}-5437$ & 19981118 & -- & $.003 E$ & -- & $<.002$ & $<.002$ & $<.003$ \\
\hline CH-5439 & 19981116 & -- & $<.001$ & -- & $<.002$ & $<.002$ & $<.003$ \\
\hline $\mathrm{CH}-5440$ & 19981104 & -- & $<.001$ & -- & $<.002$ & $<.002$ & $<.003$ \\
\hline $\mathrm{CH}-5442$ & 19981124 & -- & $<.001$ & -- & $<.002$ & $<.002$ & $<.003$ \\
\hline $\mathrm{CH}-5443$ & 19981112 & -- & .005 & -- & $<.002$ & $<.002$ & $<.003$ \\
\hline $\mathrm{CH}-5450$ & 20000911 & -- & $<.001$ & -- & $<.002$ & $<.002$ & $<.003$ \\
\hline $\mathrm{CH}-5470$ & 19960822 & -- & .007 & -- & $<.002$ & $<.002$ & $<.003$ \\
\hline $\mathrm{CH}-5476$ & 19960904 & -- & -- & -- & -- & -- & -- \\
\hline $\mathrm{CH}-5477$ & 19960904 & -- & -- & -- & -- & -- & -- \\
\hline CE Ae 8 & 19981028 & -- & $<.004$ & -- & $<.002$ & $<.002$ & $.007 \mathrm{E}$ \\
\hline CE Ae 9 & 19981026 & -- & $<.001$ & -- & $<.002$ & $<.002$ & $<.003$ \\
\hline CE Ae 13 & 19981203 & -- & .02 & -- & $<.002$ & $<.002$ & $<.003$ \\
\hline
\end{tabular}


Table 21. Results of laboratory analyses for pesticides in ground water, Big Elk Creek Basin, Pennsylvania and Maryland-Continued

\begin{tabular}{|c|c|c|c|c|c|c|c|}
\hline $\begin{array}{c}\text { Well- } \\
\text { identification } \\
\text { number }\end{array}$ & $\begin{array}{l}\text { Date of } \\
\text { sample }\end{array}$ & $\begin{array}{l}\text { Carbofuran, } \\
\text { dissolved }\end{array}$ & $\begin{array}{c}\text { Carbophenothion, } \\
\text { dissolved }\end{array}$ & $\begin{array}{c}\text { Chlordane, } \\
\text { total }\end{array}$ & $\begin{array}{l}\text { Chlorpyrifos, } \\
\text { dissolved }\end{array}$ & $\begin{array}{c}\text { Chlorpyrifos, } \\
\text { total }\end{array}$ & $\begin{array}{l}\text { Cyanazine, } \\
\text { dissolved }\end{array}$ \\
\hline $\mathrm{CH}-75$ & 19900823 & -- & $<0.01$ & $<0.1$ & -- & $<0.01$ & -- \\
\hline $\mathrm{CH}-1720$ & 19921001 & -- & -- & -- & -- & -- & $<0.200$ \\
\hline $\mathrm{CH}-1720$ & 19930610 & -- & $<.01$ & $<.1$ & -- & $<.01$ & -- \\
\hline $\mathrm{CH}-1735$ & 20000906 & $0.030 \mathrm{E}$ & -- & -- & $<0.004$ & -- & $<.004$ \\
\hline $\mathrm{CH}-2186$ & 19930818 & $<.003$ & -- & $<.1$ & $<.004$ & -- & $<.004$ \\
\hline $\mathrm{CH}-2439$ & 19810817 & -- & -- & $<.1$ & -- & -- & -- \\
\hline $\mathrm{CH}-2440$ & 19810817 & -- & -- & $<.1$ & -- & -- & -- \\
\hline $\mathrm{CH}-2459$ & 19820804 & -- & -- & $<.1$ & -- & -- & -- \\
\hline $\mathrm{CH}-2460$ & 19820804 & -- & -- & $<.1$ & -- & -- & -- \\
\hline $\mathrm{CH}-2461$ & 19820804 & -- & -- & $<.1$ & -- & -- & -- \\
\hline $\mathrm{CH}-2461$ & 19830707 & -- & $<.01$ & -- & -- & -- & -- \\
\hline $\mathrm{CH}-2461$ & 19950808 & $.010 \mathrm{E}$ & -- & $<.1$ & $<.004$ & -- & $<.004$ \\
\hline $\mathrm{CH}-3316$ & 19880808 & -- & $<.01$ & $<.1$ & -- & -- & -- \\
\hline $\mathrm{CH}-3316$ & 19900906 & -- & -- & -- & -- & -- & -- \\
\hline $\mathrm{CH}-3317$ & 19880808 & -- & $<.01$ & $<.1$ & -- & -- & -- \\
\hline $\mathrm{CH}-4126$ & 19910807 & -- & $<.01$ & $<.1$ & -- & $<.01$ & $<.200$ \\
\hline $\mathrm{CH}-4297$ & 19921001 & -- & $<.01$ & $<.1$ & -- & $<.01$ & $<.200$ \\
\hline $\mathrm{CH}-4806$ & 19940628 & -- & $<.01$ & $<.1$ & -- & $<.01$ & $<.200$ \\
\hline $\mathrm{CH}-4931$ & 19940721 & $<.003$ & -- & -- & $<.004$ & -- & $<.004$ \\
\hline $\mathrm{CH}-4933$ & 19940714 & $<.003$ & -- & -- & $<.004$ & -- & $<.004$ \\
\hline $\mathrm{CH}-5420$ & 19980615 & $<.003$ & -- & -- & $<.004$ & -- & $<.004$ \\
\hline $\mathrm{CH}-5421$ & 19980615 & $<.003$ & -- & -- & $<.004$ & -- & $<.004$ \\
\hline $\mathrm{CH}-5423$ & 19980616 & $<.003$ & -- & -- & $<.004$ & -- & $<.004$ \\
\hline $\mathrm{CH}-5424$ & 19980624 & $<.003$ & -- & -- & $<.004$ & -- & $<.004$ \\
\hline $\mathrm{CH}-5425$ & 19980701 & $<.003$ & -- & -- & $<.004$ & -- & $<.004$ \\
\hline $\mathrm{CH}-5426$ & 19981105 & $<.003$ & -- & -- & $<.004$ & -- & $<.004$ \\
\hline $\mathrm{CH}-5428$ & 19981103 & $<.003$ & -- & -- & $<.004$ & -- & $<.004$ \\
\hline $\mathrm{CH}-5430$ & 19980707 & $<.003$ & -- & -- & $<.004$ & -- & $<.004$ \\
\hline $\mathrm{CH}-5431$ & 19980707 & $<.003$ & -- & -- & $<.004$ & -- & $<.004$ \\
\hline $\mathrm{CH}-5432$ & 19980714 & $<.003$ & -- & -- & $<.004$ & -- & $<.004$ \\
\hline $\mathrm{CH}-5433$ & 19980714 & $<.003$ & -- & -- & $<.004$ & -- & $<.004$ \\
\hline $\mathrm{CH}-5434$ & 19980715 & $<.003$ & -- & -- & $<.004$ & -- & $<.004$ \\
\hline $\mathrm{CH}-5437$ & 19981118 & $<.003$ & -- & -- & $<.004$ & -- & $<.004$ \\
\hline $\mathrm{CH}-5439$ & 19981116 & $<.003$ & -- & -- & $<.004$ & -- & $<.004$ \\
\hline $\mathrm{CH}-5440$ & 19981104 & $<.003$ & -- & -- & $<.004$ & -- & $<.004$ \\
\hline $\mathrm{CH}-5442$ & 19981124 & $<.003$ & -- & -- & $<.004$ & -- & $<.004$ \\
\hline $\mathrm{CH}-5443$ & 19981112 & $<.003$ & -- & -- & $<.004$ & -- & $<.004$ \\
\hline $\mathrm{CH}-5450$ & 20000911 & $<.003$ & -- & -- & $<.004$ & -- & $<.004$ \\
\hline $\mathrm{CH}-5470$ & 19960822 & $.073 \mathrm{E}$ & -- & $<.1$ & $<.004$ & -- & $<.004$ \\
\hline CH-5476 & 19960904 & -- & $<.01$ & $<.1$ & -- & $<.01$ & -- \\
\hline $\mathrm{CH}-5477$ & 19960904 & -- & -- & $<.1$ & -- & -- & -- \\
\hline CE Ae 8 & 19981028 & $<.003$ & -- & -- & $<.004$ & -- & .007 \\
\hline CE Ae 9 & 19981026 & $<.003$ & -- & -- & $<.004$ & -- & $<.004$ \\
\hline CE Ae 13 & 19981203 & $<.003$ & -- & -- & $<.004$ & -- & $<.004$ \\
\hline
\end{tabular}


Table 21. Results of laboratory analyses for pesticides in ground water, Big Elk Creek Basin, Pennsylvania and Maryland-Continued

\begin{tabular}{|c|c|c|c|c|c|c|c|c|}
\hline $\begin{array}{c}\text { Well- } \\
\text { identification } \\
\text { number }\end{array}$ & $\begin{array}{l}\text { Date of } \\
\text { sample }\end{array}$ & $\begin{array}{c}\text { Cyanazine, } \\
\text { total }\end{array}$ & $\begin{array}{c}\text { DCPA, } \\
\text { dissolved }\end{array}$ & $\begin{array}{c}\text { P,P'-DDD, } \\
\text { total }\end{array}$ & $\begin{array}{l}\text { P,P' DDE, } \\
\text { dissolved }\end{array}$ & $\begin{array}{l}\text { P,P'-DDE, } \\
\text { total }\end{array}$ & $\begin{array}{l}\text { P,P'-DDT, } \\
\text { total }\end{array}$ & $\begin{array}{l}\text { Deethyl } \\
\text { atrazine, } \\
\text { dissolved }\end{array}$ \\
\hline $\mathrm{CH}-75$ & 19900823 & $<0.1$ & -- & $<0.010$ & -- & $<0.010$ & $<0.010$ & -- \\
\hline $\mathrm{CH}-1720$ & 19921001 & -- & -- & -- & -- & -- & -- & $<0.050$ \\
\hline $\mathrm{CH}-1720$ & 19930610 & -- & -- & $<.010$ & -- & $<.010$ & $<.010$ & -- \\
\hline $\mathrm{CH}-1735$ & 20000906 & -- & $<0.002$ & -- & $<0.006$ & -- & -- & $.032 \mathrm{E}$ \\
\hline $\mathrm{CH}-2186$ & 19930818 & -- & $<.002$ & $<.010$ & $<.006$ & $<.010$ & $<.010$ & $.047 \mathrm{E}$ \\
\hline $\mathrm{CH}-2439$ & 19810817 & -- & -- & $<.010$ & -- & $<.010$ & $<.010$ & -- \\
\hline $\mathrm{CH}-2440$ & 19810817 & -- & -- & $<.010$ & -- & $<.010$ & $<.010$ & -- \\
\hline $\mathrm{CH}-2459$ & 19820804 & -- & -- & $<.010$ & -- & $<.010$ & $<.010$ & -- \\
\hline $\mathrm{CH}-2460$ & 19820804 & -- & -- & $<.010$ & -- & $<.010$ & $<.010$ & -- \\
\hline $\mathrm{CH}-2461$ & 19820804 & -- & -- & $<.010$ & -- & $<.010$ & $<.010$ & -- \\
\hline $\mathrm{CH}-2461$ & 19830707 & $<.1$ & -- & -- & -- & -- & -- & -- \\
\hline $\mathrm{CH}-2461$ & 19950808 & -- & $<.002$ & $<.010$ & $<.006$ & $<.010$ & $<.010$ & $.19 \mathrm{E}$ \\
\hline $\mathrm{CH}-3316$ & 19880808 & $<.1$ & -- & $<.010$ & -- & $<.010$ & $<.010$ & -- \\
\hline $\mathrm{CH}-3316$ & 19900906 & -- & -- & -- & -- & -- & -- & -- \\
\hline $\mathrm{CH}-3317$ & 19880808 & $<.1$ & -- & $<.010$ & -- & $<.010$ & $<.010$ & -- \\
\hline $\mathrm{CH}-4126$ & 19910807 & -- & -- & $<.010$ & -- & $<.010$ & $<.010$ & .2 \\
\hline $\mathrm{CH}-4297$ & 19921001 & -- & -- & $<.010$ & -- & $<.010$ & $<.010$ & .06 \\
\hline $\mathrm{CH}-4806$ & 19940628 & -- & -- & $<.010$ & -- & $<.010$ & $<.010$ & .2 \\
\hline $\mathrm{CH}-4931$ & 19940721 & -- & $<.002$ & -- & $<.006$ & -- & -- & $.014 \mathrm{E}$ \\
\hline $\mathrm{CH}-4933$ & 19940714 & -- & $<.002$ & -- & $<.006$ & -- & -- & $.076 \mathrm{E}$ \\
\hline $\mathrm{CH}-5420$ & 19980615 & -- & $<.002$ & -- & $<.006$ & -- & -- & $.28 \mathrm{E}$ \\
\hline $\mathrm{CH}-5421$ & 19980615 & -- & $<.002$ & -- & $<.006$ & -- & -- & $.20 \mathrm{E}$ \\
\hline $\mathrm{CH}-5423$ & 19980616 & -- & $<.002$ & -- & $<.006$ & -- & -- & $.10 \mathrm{E}$ \\
\hline $\mathrm{CH}-5424$ & 19980624 & -- & $<.002$ & -- & $<.006$ & -- & -- & $.03 \mathrm{E}$ \\
\hline $\mathrm{CH}-5425$ & 19980701 & -- & $<.002$ & -- & $<.006$ & -- & -- & $.003 \mathrm{E}$ \\
\hline $\mathrm{CH}-5426$ & 19981105 & -- & $<.002$ & -- & $<.006$ & -- & -- & $<.002$ \\
\hline CH-5428 & 19981103 & -- & $<.002$ & -- & $<.006$ & -- & -- & $.011 \mathrm{E}$ \\
\hline $\mathrm{CH}-5430$ & 19980707 & -- & $<.002$ & -- & $<.006$ & -- & -- & $.33 \mathrm{E}$ \\
\hline $\mathrm{CH}-5431$ & 19980707 & -- & $<.002$ & -- & $<.006$ & -- & -- & $<.002$ \\
\hline $\mathrm{CH}-5432$ & 19980714 & -- & $<.002$ & -- & $<.006$ & -- & -- & $<.002$ \\
\hline $\mathrm{CH}-5433$ & 19980714 & -- & $<.002$ & -- & $<.006$ & -- & -- & $<.002$ \\
\hline $\mathrm{CH}-5434$ & 19980715 & -- & $<.002$ & -- & $<.006$ & -- & -- & $<.002$ \\
\hline $\mathrm{CH}-5437$ & 19981118 & -- & $<.002$ & -- & $<.006$ & -- & -- & $.32 \mathrm{E}$ \\
\hline $\mathrm{CH}-5439$ & 19981116 & -- & $<.002$ & -- & $<.006$ & -- & -- & $<.002$ \\
\hline $\mathrm{CH}-5440$ & 19981104 & -- & $<.002$ & -- & $<.006$ & -- & -- & $<.002$ \\
\hline $\mathrm{CH}-5442$ & 19981124 & -- & $<.002$ & -- & $<.006$ & -- & -- & $.038 \mathrm{E}$ \\
\hline $\mathrm{CH}-5443$ & 19981112 & -- & $<.002$ & -- & $<.006$ & -- & -- & $.018 \mathrm{E}$ \\
\hline $\mathrm{CH}-5450$ & 20000911 & -- & $<.002$ & -- & $<.006$ & -- & -- & $<.002$ \\
\hline $\mathrm{CH}-5470$ & 19960822 & -- & $<.002$ & $<.010$ & $<.006$ & $<.010$ & $<.010$ & $.13 \mathrm{E}$ \\
\hline CH-5476 & 19960904 & -- & -- & $<.010$ & -- & $<.010$ & $<.010$ & -- \\
\hline $\mathrm{CH}-5477$ & 19960904 & -- & -- & $<.010$ & -- & $<.010$ & $<.010$ & -- \\
\hline CE Ae 8 & 19981028 & -- & $<.004$ & -- & $<.012$ & -- & -- & $.003 \mathrm{E}$ \\
\hline CE Ae 9 & 19981026 & -- & $<.002$ & -- & $<.006$ & -- & -- & $.090 \mathrm{E}$ \\
\hline $\mathrm{CE}$ Ae 13 & 19981203 & -- & $<.002$ & -- & $<.006$ & -- & -- & $.038 \mathrm{E}$ \\
\hline
\end{tabular}


Table 21. Results of laboratory analyses for pesticides in ground water, Big Elk Creek Basin, Pennsylvania and Maryland-Continued

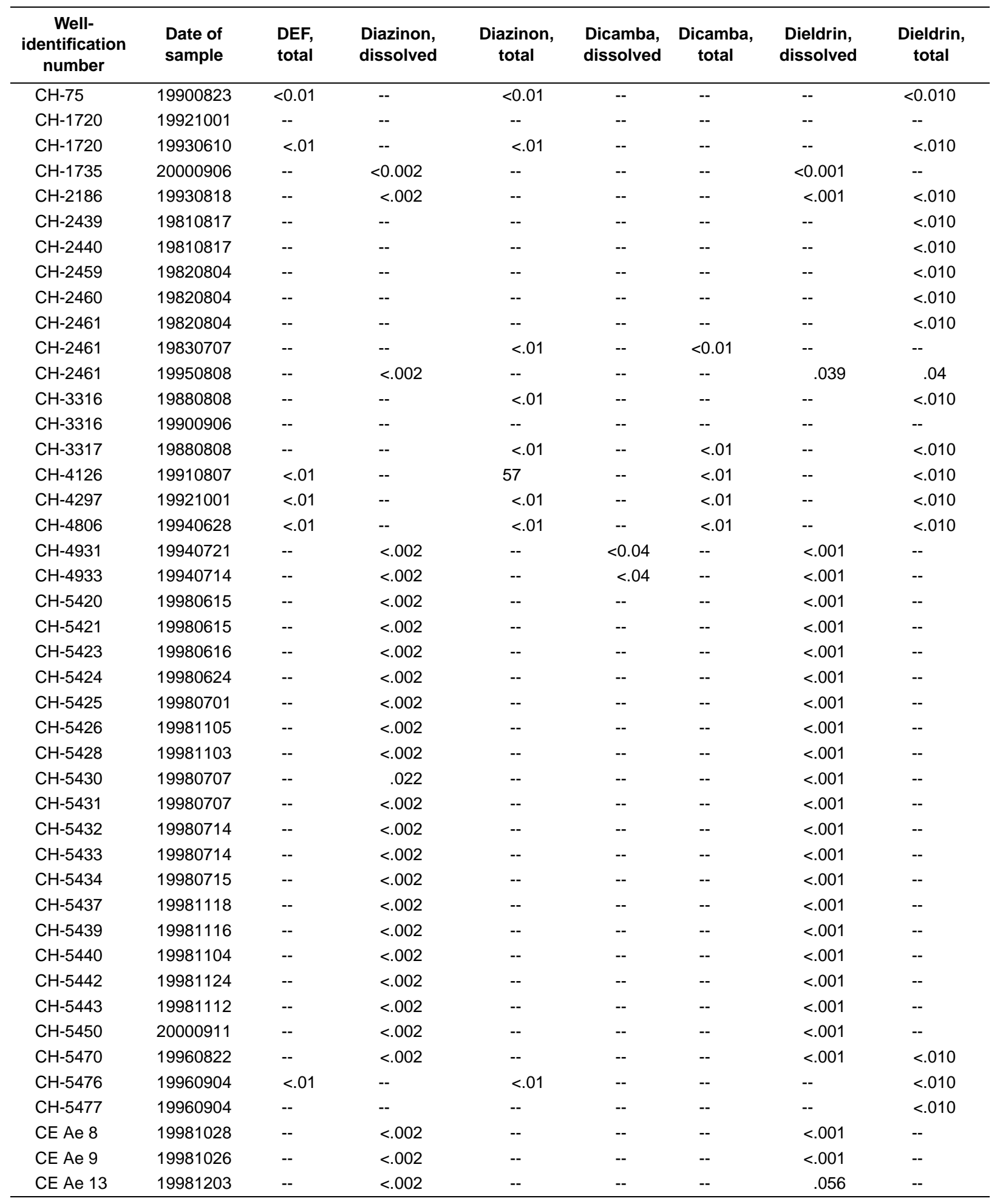


Table 21. Results of laboratory analyses for pesticides in ground water, Big Elk Creek Basin, Pennsylvania and Maryland-Continued

\begin{tabular}{|c|c|c|c|c|c|c|c|c|}
\hline $\begin{array}{c}\text { Well- } \\
\text { identification } \\
\text { number }\end{array}$ & $\begin{array}{l}\text { Date of } \\
\text { sample }\end{array}$ & $\begin{array}{l}\text { Disulfoton, } \\
\text { dissolved }\end{array}$ & $\begin{array}{l}\text { Disulfoton, } \\
\text { total }\end{array}$ & $\begin{array}{l}\text { Endosulfan, } \\
\text { total }\end{array}$ & $\begin{array}{l}\text { Endrin, } \\
\text { total }\end{array}$ & $\begin{array}{c}\text { EPTC, } \\
\text { dissolved }\end{array}$ & $\begin{array}{l}\text { Ethalfluralin, } \\
\text { dissolved }\end{array}$ & $\begin{array}{l}\text { Ethion, } \\
\text { total }\end{array}$ \\
\hline $\mathrm{CH}-75$ & 19900823 & -- & $<0.01$ & $<0.010$ & $<0.010$ & -- & -- & $<0.01$ \\
\hline $\mathrm{CH}-1720$ & 19921001 & -- & -- & -- & -- & -- & -- & -- \\
\hline $\mathrm{CH}-1720$ & 19930610 & -- & $<.01$ & $<.010$ & $<.010$ & -- & -- & $<.01$ \\
\hline $\mathrm{CH}-1735$ & 20000906 & $<0.017$ & -- & -- & -- & $<0.002$ & $<0.004$ & -- \\
\hline $\mathrm{CH}-2186$ & 19930818 & $<.017$ & -- & $<.010$ & $<.010$ & $<.002$ & $<.004$ & -- \\
\hline $\mathrm{CH}-2439$ & 19810817 & -- & -- & $<.010$ & $<.010$ & -- & -- & -- \\
\hline $\mathrm{CH}-2440$ & 19810817 & -- & -- & $<.010$ & $<.010$ & -- & -- & -- \\
\hline $\mathrm{CH}-2459$ & 19820804 & -- & -- & $<.010$ & $<.010$ & -- & -- & -- \\
\hline $\mathrm{CH}-2460$ & 19820804 & -- & -- & $<.010$ & $<.010$ & -- & -- & -- \\
\hline $\mathrm{CH}-2461$ & 19820804 & -- & -- & $<.010$ & $<.010$ & -- & -- & -- \\
\hline $\mathrm{CH}-2461$ & 19830707 & -- & -- & -- & -- & -- & -- & $<.01$ \\
\hline $\mathrm{CH}-2461$ & 19950808 & $<.017$ & -- & $<.010$ & $<.010$ & .01 & $<.004$ & -- \\
\hline $\mathrm{CH}-3316$ & 19880808 & -- & -- & $<.010$ & $<.010$ & -- & -- & $<.01$ \\
\hline $\mathrm{CH}-3316$ & 19900906 & -- & -- & -- & -- & -- & -- & -- \\
\hline $\mathrm{CH}-3317$ & 19880808 & -- & -- & $<.010$ & $<.010$ & -- & -- & $<.01$ \\
\hline $\mathrm{CH}-4126$ & 19910807 & -- & $<.01$ & $<.010$ & $<.010$ & -- & -- & .02 \\
\hline $\mathrm{CH}-4297$ & 19921001 & -- & $<.01$ & $<.010$ & $<.010$ & -- & -- & $<.01$ \\
\hline $\mathrm{CH}-4806$ & 19940628 & -- & $<.01$ & $<.010$ & $<.010$ & -- & -- & $<.01$ \\
\hline $\mathrm{CH}-4931$ & 19940721 & $<.017$ & -- & -- & -- & $<.002$ & $<.004$ & -- \\
\hline $\mathrm{CH}-4933$ & 19940714 & $<.017$ & -- & -- & -- & $<.002$ & $<.004$ & -- \\
\hline $\mathrm{CH}-5420$ & 19980615 & $<.017$ & -- & -- & -- & $<.002$ & $<.004$ & -- \\
\hline $\mathrm{CH}-5421$ & 19980615 & $<.017$ & -- & -- & -- & $<.002$ & $<.004$ & -- \\
\hline $\mathrm{CH}-5423$ & 19980616 & $<.017$ & -- & -- & -- & $<.002$ & $<.004$ & -- \\
\hline $\mathrm{CH}-5424$ & 19980624 & $<.017$ & -- & -- & -- & $<.002$ & $<.004$ & -- \\
\hline $\mathrm{CH}-5425$ & 19980701 & $<.017$ & -- & -- & -- & $<.002$ & $<.004$ & -- \\
\hline $\mathrm{CH}-5426$ & 19981105 & $<.017$ & -- & -- & -- & $<.002$ & $<.004$ & -- \\
\hline $\mathrm{CH}-5428$ & 19981103 & $<.017$ & -- & -- & -- & $<.002$ & $<.004$ & -- \\
\hline $\mathrm{CH}-5430$ & 19980707 & $<.017$ & -- & -- & -- & $<.002$ & $<.004$ & -- \\
\hline $\mathrm{CH}-5431$ & 19980707 & $<.017$ & -- & -- & -- & $<.002$ & $<.004$ & -- \\
\hline $\mathrm{CH}-5432$ & 19980714 & $<.017$ & -- & -- & -- & $<.002$ & $<.004$ & -- \\
\hline $\mathrm{CH}-5433$ & 19980714 & $<.017$ & -- & -- & -- & $<.002$ & $<.004$ & -- \\
\hline $\mathrm{CH}-5434$ & 19980715 & $<.017$ & -- & -- & -- & $<.002$ & $<.004$ & -- \\
\hline $\mathrm{CH}-5437$ & 19981118 & $<.017$ & -- & -- & -- & $<.002$ & $<.004$ & -- \\
\hline CH-5439 & 19981116 & $<.017$ & -- & -- & -- & $<.002$ & $<.004$ & -- \\
\hline $\mathrm{CH}-5440$ & 19981104 & $<.017$ & -- & -- & -- & $<.002$ & $<.004$ & -- \\
\hline CH-5442 & 19981124 & $<.017$ & -- & -- & -- & $<.002$ & $<.004$ & -- \\
\hline $\mathrm{CH}-5443$ & 19981112 & $<.017$ & -- & -- & -- & $<.002$ & $<.004$ & -- \\
\hline $\mathrm{CH}-5450$ & 20000911 & $<.017$ & -- & -- & -- & $<.002$ & $<.004$ & -- \\
\hline $\mathrm{CH}-5470$ & 19960822 & $<.017$ & -- & $<.010$ & $<.010$ & $<.002$ & $<.004$ & -- \\
\hline $\mathrm{CH}-5476$ & 19960904 & -- & $<.01$ & $<.010$ & $<.010$ & -- & -- & $<.01$ \\
\hline CH-5477 & 19960904 & -- & -- & $<.010$ & $<.010$ & -- & -- & -- \\
\hline CE Ae 8 & 19981028 & $<.017$ & -- & -- & -- & $<.002$ & $<.004$ & -- \\
\hline CE Ae 9 & 19981026 & $<.017$ & -- & -- & -- & $<.002$ & $<.004$ & -- \\
\hline CE Ae 13 & 19981203 & $<.017$ & -- & -- & -- & $<.002$ & $<.004$ & -- \\
\hline
\end{tabular}


Table 21. Results of laboratory analyses for pesticides in ground water, Big Elk Creek Basin, Pennsylvania and Maryland-Continued

\begin{tabular}{|c|c|c|c|c|c|c|c|c|}
\hline $\begin{array}{c}\text { Well- } \\
\text { identification } \\
\text { number }\end{array}$ & $\begin{array}{l}\text { Date of } \\
\text { sample }\end{array}$ & $\begin{array}{l}\text { Ethoprop, } \\
\text { dissolved }\end{array}$ & $\begin{array}{l}\text { Fonofos, } \\
\text { dissolved }\end{array}$ & $\begin{array}{c}\text { Fonofos, } \\
\text { total }\end{array}$ & $\begin{array}{l}\text { Heptachlor, } \\
\text { total }\end{array}$ & $\begin{array}{l}\text { Heptachlor } \\
\text { epoxide, } \\
\text { total }\end{array}$ & $\begin{array}{l}\text { Lindane, } \\
\text { dissolved }\end{array}$ & $\begin{array}{c}\text { Lindane, } \\
\text { total }\end{array}$ \\
\hline $\mathrm{CH}-75$ & 19900823 & -- & -- & $<0.01$ & $<0.010$ & $<0.010$ & -- & $<0.010$ \\
\hline $\mathrm{CH}-1720$ & 19921001 & -- & -- & -- & -- & -- & -- & -- \\
\hline $\mathrm{CH}-1720$ & 19930610 & -- & -- & $<.01$ & $<.010$ & $<.010$ & -- & .02 \\
\hline $\mathrm{CH}-1735$ & 20000906 & $<0.003$ & $<0.003$ & -- & -- & -- & $<0.004$ & \\
\hline $\mathrm{CH}-2186$ & 19930818 & $<.003$ & $<.003$ & -- & $<.010$ & $<.010$ & $<.004$ & $<.010$ \\
\hline $\mathrm{CH}-2439$ & 19810817 & -- & -- & -- & $<.010$ & $<.010$ & -- & $<.010$ \\
\hline $\mathrm{CH}-2440$ & 19810817 & -- & -- & -- & $<.010$ & $<.010$ & -- & $<.010$ \\
\hline $\mathrm{CH}-2459$ & 19820804 & -- & -- & -- & $<.010$ & $<.010$ & -- & $<.010$ \\
\hline $\mathrm{CH}-2460$ & 19820804 & -- & -- & -- & $<.010$ & $<.010$ & -- & $<.010$ \\
\hline $\mathrm{CH}-2461$ & 19820804 & -- & -- & -- & $<.010$ & $<.010$ & -- & $<.010$ \\
\hline $\mathrm{CH}-2461$ & 19830707 & -- & -- & -- & -- & -- & -- & -- \\
\hline $\mathrm{CH}-2461$ & 19950808 & $<.003$ & $<.003$ & -- & $<.010$ & $<.010$ & $<.004$ & $<.010$ \\
\hline $\mathrm{CH}-3316$ & 19880808 & -- & -- & -- & $<.010$ & $<.010$ & -- & $<.010$ \\
\hline $\mathrm{CH}-3316$ & 19900906 & -- & -- & -- & -- & -- & -- & -- \\
\hline $\mathrm{CH}-3317$ & 19880808 & -- & -- & -- & $<.010$ & $<.010$ & -- & $<.010$ \\
\hline $\mathrm{CH}-4126$ & 19910807 & -- & -- & $<.02$ & $<.010$ & $<.010$ & -- & .03 \\
\hline $\mathrm{CH}-4297$ & 19921001 & -- & -- & $<.01$ & $<.010$ & $<.010$ & -- & $<.010$ \\
\hline $\mathrm{CH}-4806$ & 19940628 & -- & -- & $<.01$ & $<.010$ & $<.010$ & -- & $<.010$ \\
\hline $\mathrm{CH}-4931$ & 19940721 & $<.003$ & $<.003$ & -- & -- & -- & $<.004$ & -- \\
\hline $\mathrm{CH}-4933$ & 19940714 & $<.003$ & $<.003$ & -- & -- & -- & $<.004$ & -- \\
\hline $\mathrm{CH}-5420$ & 19980615 & $<.003$ & $<.003$ & -- & -- & -- & $<.004$ & -- \\
\hline $\mathrm{CH}-5421$ & 19980615 & $<.003$ & $<.003$ & -- & -- & -- & $<.004$ & -- \\
\hline $\mathrm{CH}-5423$ & 19980616 & $<.003$ & $<.003$ & -- & -- & -- & $<.004$ & -- \\
\hline $\mathrm{CH}-5424$ & 19980624 & $<.003$ & $<.003$ & -- & -- & -- & $<.004$ & -- \\
\hline $\mathrm{CH}-5425$ & 19980701 & $<.003$ & $<.003$ & -- & -- & -- & $<.004$ & -- \\
\hline $\mathrm{CH}-5426$ & 19981105 & $<.003$ & $<.003$ & -- & -- & -- & $<.004$ & -- \\
\hline $\mathrm{CH}-5428$ & 19981103 & $<.003$ & $<.003$ & -- & -- & -- & $<.004$ & -- \\
\hline $\mathrm{CH}-5430$ & 19980707 & $<.003$ & $<.003$ & -- & -- & -- & $<.004$ & -- \\
\hline $\mathrm{CH}-5431$ & 19980707 & $<.003$ & $<.003$ & -- & -- & -- & $<.004$ & -- \\
\hline $\mathrm{CH}-5432$ & 19980714 & $<.003$ & $<.003$ & -- & -- & -- & $<.004$ & -- \\
\hline $\mathrm{CH}-5433$ & 19980714 & $<.003$ & $<.003$ & -- & -- & -- & $<.004$ & -- \\
\hline $\mathrm{CH}-5434$ & 19980715 & $<.003$ & $<.003$ & -- & -- & -- & $<.004$ & -- \\
\hline $\mathrm{CH}-5437$ & 19981118 & $<.003$ & $<.003$ & -- & -- & -- & $<.004$ & -- \\
\hline $\mathrm{CH}-5439$ & 19981116 & $<.003$ & $<.003$ & -- & -- & -- & $<.004$ & -- \\
\hline $\mathrm{CH}-5440$ & 19981104 & $<.003$ & $<.003$ & -- & -- & -- & $<.004$ & -- \\
\hline $\mathrm{CH}-5442$ & 19981124 & $<.003$ & $<.003$ & -- & -- & -- & $<.004$ & -- \\
\hline $\mathrm{CH}-5443$ & 19981112 & $<.003$ & -- & -- & -- & -- & $<.004$ & -- \\
\hline $\mathrm{CH}-5450$ & 20000911 & $<.003$ & $<.003$ & -- & -- & -- & $<.004$ & -- \\
\hline $\mathrm{CH}-5470$ & 19960822 & $<.003$ & $<.003$ & -- & $<.010$ & $<.010$ & $<.004$ & $<.010$ \\
\hline $\mathrm{CH}-5476$ & 19960904 & -- & -- & $<.01$ & $<.010$ & $<.010$ & -- & $<.010$ \\
\hline $\mathrm{CH}-5477$ & 19960904 & -- & -- & -- & $<.010$ & $<.010$ & -- & $<.010$ \\
\hline CE Ae 8 & 19981028 & $<.003$ & $<.003$ & -- & -- & -- & $<.004$ & -- \\
\hline CE Ae 9 & 19981026 & $<.003$ & $<.003$ & -- & -- & -- & $<.004$ & -- \\
\hline $\mathrm{CE}$ Ae 13 & 19981203 & $<.003$ & $<.003$ & -- & -- & -- & $<.004$ & -- \\
\hline
\end{tabular}


Table 21. Results of laboratory analyses for pesticides in ground water, Big Elk Creek Basin, Pennsylvania and Maryland-Continued

\begin{tabular}{|c|c|c|c|c|c|c|c|c|}
\hline $\begin{array}{c}\text { Well- } \\
\text { identification } \\
\text { number }\end{array}$ & $\begin{array}{l}\text { Date of } \\
\text { sample }\end{array}$ & $\begin{array}{l}\text { Linuron, } \\
\text { dissolved }\end{array}$ & $\begin{array}{l}\text { Malathion, } \\
\text { dissolved }\end{array}$ & $\begin{array}{c}\text { Malathion, } \\
\text { total }\end{array}$ & $\begin{array}{c}\text { Methyl } \\
\text { azinphos, } \\
\text { dissolved }\end{array}$ & $\begin{array}{c}\text { Methyl } \\
\text { parathion, } \\
\text { total }\end{array}$ & $\begin{array}{c}\text { Methyl } \\
\text { parathion, } \\
\text { dissolved }\end{array}$ & $\begin{array}{l}\text { Methoxychlor } \\
\text { total }\end{array}$ \\
\hline $\mathrm{CH}-75$ & 19900823 & -- & -- & $<0.01$ & -- & $<0.01$ & -- & $<0.01$ \\
\hline $\mathrm{CH}-1720$ & 19921001 & -- & -- & -- & -- & -- & -- & -- \\
\hline $\mathrm{CH}-1720$ & 19930610 & -- & -- & $<.01$ & -- & $<.01$ & -- & $<.01$ \\
\hline $\mathrm{CH}-1735$ & 20000906 & $<0.002$ & $<0.005$ & -- & $<0.001$ & -- & $<0.006$ & -- \\
\hline $\mathrm{CH}-2186$ & 19930818 & $<.002$ & $<.005$ & -- & $<.001$ & -- & $<.006$ & $<.01$ \\
\hline $\mathrm{CH}-2439$ & 19810817 & -- & -- & -- & -- & -- & -- & $<.01$ \\
\hline $\mathrm{CH}-2440$ & 19810817 & -- & -- & -- & -- & -- & -- & $<.01$ \\
\hline $\mathrm{CH}-2459$ & 19820804 & -- & -- & -- & -- & -- & -- & $<.01$ \\
\hline $\mathrm{CH}-2460$ & 19820804 & -- & -- & -- & -- & -- & -- & $<.01$ \\
\hline $\mathrm{CH}-2461$ & 19820804 & -- & -- & -- & -- & -- & -- & $<.01$ \\
\hline $\mathrm{CH}-2461$ & 19830707 & -- & -- & $<.01$ & -- & $<.01$ & -- & -- \\
\hline $\mathrm{CH}-2461$ & 19950808 & $<.002$ & $.002 \mathrm{E}$ & -- & $<.001$ & -- & $<.006$ & $<.01$ \\
\hline $\mathrm{CH}-3316$ & 19880808 & -- & -- & $<.01$ & -- & $<.01$ & -- & $<.01$ \\
\hline $\mathrm{CH}-3316$ & 19900906 & -- & -- & -- & -- & -- & -- & -- \\
\hline $\mathrm{CH}-3317$ & 19880808 & -- & -- & $<.01$ & -- & $<.01$ & -- & $<.01$ \\
\hline $\mathrm{CH}-4126$ & 19910807 & -- & -- & 25 & -- & $<.01$ & -- & .09 \\
\hline $\mathrm{CH}-4297$ & 19921001 & -- & -- & $<.01$ & -- & $<.01$ & -- & $<.01$ \\
\hline $\mathrm{CH}-4806$ & 19940628 & -- & -- & $<.01$ & -- & $<.01$ & -- & $<.01$ \\
\hline $\mathrm{CH}-4931$ & 19940721 & $<.002$ & $<.005$ & -- & $<.001$ & -- & $<.006$ & -- \\
\hline $\mathrm{CH}-4933$ & 19940714 & $<.002$ & $<.005$ & -- & $<.001$ & -- & $<.006$ & -- \\
\hline $\mathrm{CH}-5420$ & 19980615 & $<.002$ & $<.005$ & -- & $<.001$ & -- & $<.006$ & -- \\
\hline $\mathrm{CH}-5421$ & 19980615 & $<.002$ & $<.005$ & -- & $<.001$ & -- & $<.006$ & -- \\
\hline $\mathrm{CH}-5423$ & 19980616 & $<.002$ & $<.005$ & -- & $<.001$ & -- & $<.006$ & -- \\
\hline $\mathrm{CH}-5424$ & 19980624 & $<.002$ & $<.005$ & -- & $<.001$ & -- & $<.006$ & -- \\
\hline $\mathrm{CH}-5425$ & 19980701 & $<.002$ & $<.005$ & -- & $<.001$ & -- & $<.006$ & -- \\
\hline $\mathrm{CH}-5426$ & 19981105 & $<.002$ & $<.005$ & -- & $<.001$ & -- & $<.006$ & -- \\
\hline $\mathrm{CH}-5428$ & 19981103 & $<.002$ & $<.005$ & -- & $<.001$ & -- & $<.006$ & -- \\
\hline $\mathrm{CH}-5430$ & 19980707 & $<.002$ & $<.005$ & -- & $<.001$ & -- & $<.006$ & -- \\
\hline $\mathrm{CH}-5431$ & 19980707 & $<.002$ & $<.005$ & -- & $<.001$ & -- & $<.006$ & -- \\
\hline $\mathrm{CH}-5432$ & 19980714 & $<.002$ & $<.005$ & -- & $<.001$ & -- & $<.006$ & -- \\
\hline $\mathrm{CH}-5433$ & 19980714 & $<.002$ & $<.005$ & -- & $<.001$ & -- & $<.006$ & -- \\
\hline $\mathrm{CH}-5434$ & 19980715 & $<.002$ & $<.005$ & -- & $<.001$ & -- & $<.006$ & -- \\
\hline $\mathrm{CH}-5437$ & 19981118 & $<.002$ & $<.005$ & -- & $<.001$ & -- & $<.006$ & -- \\
\hline $\mathrm{CH}-5439$ & 19981116 & $<.002$ & $<.005$ & -- & $<.001$ & -- & $<.006$ & -- \\
\hline $\mathrm{CH}-5440$ & 19981104 & $<.002$ & $<.005$ & -- & $<.001$ & -- & $<.006$ & -- \\
\hline $\mathrm{CH}-5442$ & 19981124 & $<.002$ & $<.005$ & -- & $<.001$ & -- & $<.006$ & -- \\
\hline $\mathrm{CH}-5443$ & 19981112 & $<.002$ & $<.005$ & -- & $<.001$ & -- & $<.006$ & -- \\
\hline $\mathrm{CH}-5450$ & 20000911 & $<.002$ & $<.005$ & -- & $<.001$ & -- & $<.006$ & -- \\
\hline $\mathrm{CH}-5470$ & 19960822 & $<.002$ & $<.005$ & -- & $<.001$ & -- & $<.006$ & $<.01$ \\
\hline $\mathrm{CH}-5476$ & 19960904 & -- & -- & $<.01$ & -- & $<.01$ & -- & $<.01$ \\
\hline $\mathrm{CH}-5477$ & 19960904 & -- & -- & -- & -- & -- & -- & $<.01$ \\
\hline $\mathrm{CE}$ Ae 8 & 19981028 & $<.002$ & $<.010$ & -- & $<.001$ & -- & $<.006$ & -- \\
\hline CE Ae 9 & 19981026 & $<.002$ & $<.005$ & -- & $<.001$ & -- & $<.006$ & -- \\
\hline $\mathrm{CE}$ Ae 13 & 19981203 & $<.002$ & $<.005$ & -- & $<.001$ & -- & $<.006$ & -- \\
\hline
\end{tabular}


Table 21. Results of laboratory analyses for pesticides in ground water, Big Elk Creek Basin, Pennsylvania and Maryland-Continued

\begin{tabular}{|c|c|c|c|c|c|c|c|c|}
\hline $\begin{array}{c}\text { Well- } \\
\text { identification } \\
\text { number }\end{array}$ & $\begin{array}{l}\text { Date of } \\
\text { sample }\end{array}$ & $\begin{array}{l}\text { Metolachlor, } \\
\text { total }\end{array}$ & $\begin{array}{l}\text { Metolachlor, } \\
\text { dissolved }\end{array}$ & $\begin{array}{l}\text { Metribuzin, } \\
\text { dissolved }\end{array}$ & $\begin{array}{l}\text { Metribuzin, } \\
\text { total }\end{array}$ & $\begin{array}{c}\text { Mirex, } \\
\text { total }\end{array}$ & $\begin{array}{l}\text { Molinate, } \\
\text { dissolved }\end{array}$ & $\begin{array}{c}\text { Napropamide, } \\
\text { dissolved }\end{array}$ \\
\hline $\mathrm{CH}-75$ & 19900823 & 0.1 & -- & -- & $<0.1$ & $<0.01$ & -- & -- \\
\hline $\mathrm{CH}-1720$ & 19921001 & -- & $<0.050$ & $<0.050$ & -- & -- & -- & -- \\
\hline $\mathrm{CH}-1720$ & 19930610 & -- & -- & -- & -- & $<.01$ & -- & -- \\
\hline $\mathrm{CH}-1735$ & 20000906 & -- & .064 & $<.004$ & -- & -- & $<0.004$ & $<0.003$ \\
\hline $\mathrm{CH}-2186$ & 19930818 & -- & .004 & $<.004$ & -- & $<.01$ & $<.004$ & $<.003$ \\
\hline $\mathrm{CH}-2439$ & 19810817 & -- & -- & -- & -- & $<.01$ & -- & -- \\
\hline $\mathrm{CH}-2440$ & 19810817 & -- & -- & -- & -- & $<.01$ & -- & -- \\
\hline $\mathrm{CH}-2459$ & 19820804 & -- & -- & -- & -- & $<.01$ & -- & -- \\
\hline $\mathrm{CH}-2460$ & 19820804 & -- & -- & -- & -- & $<.01$ & -- & -- \\
\hline $\mathrm{CH}-2461$ & 19820804 & -- & -- & -- & -- & $<.01$ & -- & -- \\
\hline $\mathrm{CH}-2461$ & 19830707 & -- & -- & -- & -- & -- & -- & -- \\
\hline $\mathrm{CH}-2461$ & 19950808 & -- & .005 & $<.004$ & -- & $<.01$ & $<.004$ & $<.003$ \\
\hline $\mathrm{CH}-3316$ & 19880808 & $<.1$ & -- & -- & $<.1$ & $<.01$ & -- & -- \\
\hline $\mathrm{CH}-3316$ & 19900906 & -- & -- & -- & -- & -- & -- & -- \\
\hline $\mathrm{CH}-3317$ & 19880808 & $<.1$ & -- & -- & $<.1$ & $<.01$ & -- & -- \\
\hline $\mathrm{CH}-4126$ & 19910807 & -- & $<.050$ & $<.050$ & -- & $<.01$ & -- & -- \\
\hline CH-4297 & 19921001 & -- & $<.050$ & $<.050$ & -- & $<.01$ & -- & -- \\
\hline $\mathrm{CH}-4806$ & 19940628 & -- & $<.050$ & $<.050$ & -- & $<.01$ & -- & -- \\
\hline $\mathrm{CH}-4931$ & 19940721 & -- & $<.002$ & $<.004$ & -- & -- & $<.004$ & $<.003$ \\
\hline $\mathrm{CH}-4933$ & 19940714 & -- & $<.002$ & $<.004$ & -- & -- & $<.004$ & $<.003$ \\
\hline $\mathrm{CH}-5420$ & 19980615 & -- & .022 & $<.004$ & -- & -- & $<.004$ & $<.003$ \\
\hline $\mathrm{CH}-5421$ & 19980615 & -- & .006 & $<.004$ & -- & -- & $<.004$ & $<.003$ \\
\hline $\mathrm{CH}-5423$ & 19980616 & -- & .007 & $<.004$ & -- & -- & $<.004$ & $<.003$ \\
\hline $\mathrm{CH}-5424$ & 19980624 & -- & $.003 \mathrm{E}$ & $<.004$ & -- & -- & $<.004$ & $<.003$ \\
\hline $\mathrm{CH}-5425$ & 19980701 & -- & $<.002$ & $<.004$ & -- & -- & $<.004$ & $<.003$ \\
\hline $\mathrm{CH}-5426$ & 19981105 & -- & $<.002$ & $<.004$ & -- & -- & $<.004$ & $<.003$ \\
\hline $\mathrm{CH}-5428$ & 19981103 & -- & $<.002$ & $<.004$ & -- & -- & $<.004$ & $<.003$ \\
\hline $\mathrm{CH}-5430$ & 19980707 & -- & .024 & $<.004$ & -- & -- & $<.004$ & $<.003$ \\
\hline $\mathrm{CH}-5431$ & 19980707 & -- & $<.002$ & $<.004$ & -- & -- & $<.004$ & $<.003$ \\
\hline $\mathrm{CH}-5432$ & 19980714 & -- & $<.002$ & $<.004$ & -- & -- & $<.004$ & $<.003$ \\
\hline $\mathrm{CH}-5433$ & 19980714 & -- & $<.002$ & $<.004$ & -- & -- & $<.004$ & $<.003$ \\
\hline $\mathrm{CH}-5434$ & 19980715 & -- & $<.002$ & $<.004$ & -- & -- & $<.004$ & $<.003$ \\
\hline $\mathrm{CH}-5437$ & 19981118 & -- & $<.002$ & $<.004$ & -- & -- & $<.004$ & $<.003$ \\
\hline $\mathrm{CH}-5439$ & 19981116 & -- & $<.002$ & $<.004$ & -- & -- & $<.004$ & $<.003$ \\
\hline $\mathrm{CH}-5440$ & 19981104 & -- & $<.002$ & $<.004$ & -- & -- & $<.004$ & $<.003$ \\
\hline $\mathrm{CH}-5442$ & 19981124 & -- & $<.002$ & $<.004$ & -- & -- & $<.004$ & $<.003$ \\
\hline $\mathrm{CH}-5443$ & 19981112 & -- & .005 & $<.004$ & -- & -- & $<.004$ & $<.003$ \\
\hline $\mathrm{CH}-5450$ & 20000911 & -- & $<.002$ & $<.004$ & -- & -- & $<.004$ & $<.003$ \\
\hline $\mathrm{CH}-5470$ & 19960822 & -- & .024 & $<.004$ & -- & $<.01$ & $<.004$ & $<.003$ \\
\hline CH-5476 & 19960904 & -- & -- & -- & -- & $<.01$ & -- & -- \\
\hline $\mathrm{CH}-5477$ & 19960904 & -- & -- & -- & -- & $<.01$ & -- & -- \\
\hline CE Ae 8 & 19981028 & -- & $<.004$ & $<.004$ & -- & -- & $<.004$ & $<.003$ \\
\hline CE Ae 9 & 19981026 & -- & $<.002$ & $<.004$ & -- & -- & $<.004$ & $<.003$ \\
\hline CE Ae 13 & 19981203 & -- & $<.002$ & $<.004$ & -- & -- & $<.004$ & $<.003$ \\
\hline
\end{tabular}


Table 21. Results of laboratory analyses for pesticides in ground water, Big Elk Creek Basin, Pennsylvania and Maryland-Continued

\begin{tabular}{|c|c|c|c|c|c|c|c|c|}
\hline $\begin{array}{c}\text { Well- } \\
\text { identification } \\
\text { number }\end{array}$ & $\begin{array}{l}\text { Date of } \\
\text { sample }\end{array}$ & $\begin{array}{l}\text { Parathion, } \\
\text { dissolved }\end{array}$ & $\begin{array}{c}\text { Parathion, } \\
\text { total }\end{array}$ & $\begin{array}{l}\text { Pebulate, } \\
\text { dissolved }\end{array}$ & $\begin{array}{l}\text { Pendimethalin, } \\
\text { dissolved }\end{array}$ & $\begin{array}{l}\text { Permethrin, } \\
\text { dissolved }\end{array}$ & $\begin{array}{c}\text { Perthane, } \\
\text { total }\end{array}$ & $\begin{array}{l}\text { Phorate, } \\
\text { dissolved }\end{array}$ \\
\hline $\mathrm{CH}-75$ & 19900823 & -- & $<0.01$ & -- & -- & -- & $<0.1$ & -- \\
\hline $\mathrm{CH}-1720$ & 19921001 & -- & -- & -- & -- & -- & -- & -- \\
\hline $\mathrm{CH}-1720$ & 19930610 & -- & $<.01$ & -- & -- & -- & $<.1$ & -- \\
\hline $\mathrm{CH}-1735$ & 20000906 & $<0.004$ & -- & $<0.004$ & $<0.004$ & $<0.005$ & & $<0.002$ \\
\hline $\mathrm{CH}-2186$ & 19930818 & $<.004$ & -- & $<.004$ & $<.004$ & $<.005$ & $<.1$ & $<.002$ \\
\hline $\mathrm{CH}-2439$ & 19810817 & -- & -- & -- & -- & -- & $<.1$ & -- \\
\hline $\mathrm{CH}-2440$ & 19810817 & -- & -- & -- & -- & -- & $<.1$ & -- \\
\hline $\mathrm{CH}-2459$ & 19820804 & -- & -- & -- & -- & -- & $<.1$ & -- \\
\hline $\mathrm{CH}-2460$ & 19820804 & -- & -- & -- & -- & -- & $<.1$ & -- \\
\hline $\mathrm{CH}-2461$ & 19820804 & -- & -- & -- & -- & -- & $<.1$ & -- \\
\hline $\mathrm{CH}-2461$ & 19830707 & -- & $<.01$ & -- & -- & -- & -- & -- \\
\hline $\mathrm{CH}-2461$ & 19950808 & $<.004$ & & $<.004$ & $<.004$ & $<.005$ & $<.1$ & $<.002$ \\
\hline $\mathrm{CH}-3316$ & 19880808 & -- & $<.01$ & -- & -- & -- & $<.1$ & -- \\
\hline $\mathrm{CH}-3316$ & 19900906 & -- & -- & -- & -- & -- & -- & -- \\
\hline $\mathrm{CH}-3317$ & 19880808 & -- & $<.01$ & -- & -- & -- & $<.1$ & -- \\
\hline $\mathrm{CH}-4126$ & 19910807 & -- & $<.01$ & -- & -- & -- & $<.1$ & -- \\
\hline $\mathrm{CH}-4297$ & 19921001 & -- & $<.01$ & -- & -- & -- & $<.1$ & -- \\
\hline $\mathrm{CH}-4806$ & 19940628 & -- & $<.01$ & -- & -- & -- & $<.1$ & -- \\
\hline $\mathrm{CH}-4931$ & 19940721 & $<.004$ & -- & $<.004$ & $<.004$ & $<.005$ & -- & $<.002$ \\
\hline $\mathrm{CH}-4933$ & 19940714 & $<.004$ & -- & $<.004$ & $<.004$ & $<.005$ & -- & $<.002$ \\
\hline $\mathrm{CH}-5420$ & 19980615 & $<.004$ & -- & $<.004$ & $<.004$ & $<.005$ & -- & $<.002$ \\
\hline $\mathrm{CH}-5421$ & 19980615 & $<.004$ & -- & $<.004$ & $<.004$ & $<.005$ & -- & $<.002$ \\
\hline $\mathrm{CH}-5423$ & 19980616 & $<.004$ & -- & $<.004$ & $<.004$ & $<.005$ & -- & $<.002$ \\
\hline $\mathrm{CH}-5424$ & 19980624 & $<.004$ & -- & $<.004$ & $<.004$ & $<.005$ & -- & $<.002$ \\
\hline $\mathrm{CH}-5425$ & 19980701 & $<.004$ & -- & $<.004$ & $<.004$ & $<.005$ & -- & $<.002$ \\
\hline $\mathrm{CH}-5426$ & 19981105 & $<.004$ & -- & $<.004$ & $<.004$ & $<.005$ & -- & $<.002$ \\
\hline CH-5428 & 19981103 & $<.004$ & -- & $<.004$ & $<.004$ & $<.005$ & -- & $<.002$ \\
\hline $\mathrm{CH}-5430$ & 19980707 & $<.004$ & -- & $<.004$ & $<.004$ & $<.005$ & -- & $<.002$ \\
\hline $\mathrm{CH}-5431$ & 19980707 & $<.004$ & -- & $<.004$ & $<.004$ & $<.005$ & -- & $<.002$ \\
\hline $\mathrm{CH}-5432$ & 19980714 & $<.004$ & -- & $<.004$ & $<.004$ & $<.005$ & -- & $<.002$ \\
\hline $\mathrm{CH}-5433$ & 19980714 & $<.004$ & -- & $<.004$ & $<.004$ & $<.005$ & -- & $<.002$ \\
\hline $\mathrm{CH}-5434$ & 19980715 & $<.004$ & -- & $<.004$ & $<.004$ & $<.005$ & -- & $<.002$ \\
\hline $\mathrm{CH}-5437$ & 19981118 & $<.004$ & -- & $<.004$ & $<.004$ & $<.005$ & -- & $<.002$ \\
\hline $\mathrm{CH}-5439$ & 19981116 & $<.004$ & -- & $<.004$ & $<.004$ & $<.005$ & -- & $<.002$ \\
\hline $\mathrm{CH}-5440$ & 19981104 & $<.004$ & -- & $<.004$ & $<.004$ & $<.005$ & -- & $<.002$ \\
\hline CH-5442 & 19981124 & $<.004$ & -- & $<.004$ & $<.004$ & $<.005$ & -- & $<.002$ \\
\hline $\mathrm{CH}-5443$ & 19981112 & $<.004$ & -- & $<.004$ & $<.004$ & $<.005$ & -- & $<.002$ \\
\hline $\mathrm{CH}-5450$ & 20000911 & $<.004$ & -- & $<.004$ & $<.004$ & $<.005$ & -- & $<.002$ \\
\hline $\mathrm{CH}-5470$ & 19960822 & $<.004$ & -- & $<.004$ & $<.004$ & $<.005$ & $<.1$ & $<.002$ \\
\hline $\mathrm{CH}-5476$ & 19960904 & -- & $<.01$ & -- & -- & -- & $<.1$ & -- \\
\hline $\mathrm{CH}-5477$ & 19960904 & -- & -- & -- & -- & -- & $<.1$ & -- \\
\hline CE Ae 8 & 19981028 & $<.004$ & -- & $<.004$ & $<.004$ & $<.005$ & -- & $<.002$ \\
\hline CE Ae 9 & 19981026 & $<.004$ & -- & $<.004$ & $<.004$ & $<.005$ & -- & $<.002$ \\
\hline $\mathrm{CE} A \mathrm{Ae} 13$ & 19981203 & $<.004$ & -- & $<.004$ & $<.004$ & $<.005$ & -- & $<.002$ \\
\hline
\end{tabular}


Table 21. Results of laboratory analyses for pesticides in ground water, Big Elk Creek Basin, Pennsylvania and Maryland-Continued

\begin{tabular}{|c|c|c|c|c|c|c|c|c|}
\hline $\begin{array}{c}\text { Well- } \\
\text { identification } \\
\text { number }\end{array}$ & $\begin{array}{l}\text { Date of } \\
\text { sample }\end{array}$ & $\begin{array}{c}\text { Phorate, } \\
\text { total }\end{array}$ & $\begin{array}{l}\text { Picloram, } \\
\text { dissolved }\end{array}$ & $\begin{array}{c}\text { Picloram, } \\
\text { total }\end{array}$ & $\begin{array}{l}\text { Prometon, } \\
\text { dissolved }\end{array}$ & $\begin{array}{c}\text { Prometone, } \\
\text { total }\end{array}$ & $\begin{array}{l}\text { Prometryn, } \\
\text { dissolved }\end{array}$ & $\begin{array}{c}\text { Prometryne, } \\
\text { total }\end{array}$ \\
\hline $\mathrm{CH}-75$ & 19900823 & $<0.01$ & -- & -- & -- & $<0.1$ & -- & $<0.1$ \\
\hline $\mathrm{CH}-1720$ & 19921001 & -- & -- & -- & $<0.050$ & -- & $<0.05$ & -- \\
\hline $\mathrm{CH}-1720$ & 19930610 & $<.01$ & -- & -- & & -- & -- & -- \\
\hline $\mathrm{CH}-1735$ & 20000906 & -- & -- & -- & $<.018$ & -- & -- & -- \\
\hline $\mathrm{CH}-2186$ & 19930818 & -- & -- & -- & $<.018$ & -- & -- & -- \\
\hline $\mathrm{CH}-2439$ & 19810817 & -- & -- & -- & -- & -- & -- & -- \\
\hline $\mathrm{CH}-2440$ & 19810817 & -- & -- & -- & -- & -- & -- & -- \\
\hline $\mathrm{CH}-2459$ & 19820804 & -- & -- & -- & -- & -- & -- & -- \\
\hline $\mathrm{CH}-2460$ & 19820804 & -- & -- & -- & -- & -- & -- & -- \\
\hline $\mathrm{CH}-2461$ & 19820804 & -- & -- & -- & -- & -- & -- & -- \\
\hline $\mathrm{CH}-2461$ & 19830707 & -- & -- & $<0.01$ & -- & $<.1$ & -- & $<.1$ \\
\hline $\mathrm{CH}-2461$ & 19950808 & -- & -- & -- & $<.018$ & & -- & -- \\
\hline $\mathrm{CH}-3316$ & 19880808 & -- & -- & -- & -- & $<.1$ & -- & $<.1$ \\
\hline $\mathrm{CH}-3316$ & 19900906 & -- & -- & -- & -- & -- & -- & -- \\
\hline $\mathrm{CH}-3317$ & 19880808 & -- & -- & $<.01$ & -- & $<.1$ & -- & $<.1$ \\
\hline $\mathrm{CH}-4126$ & 19910807 & $<.02$ & -- & .32 & $<.050$ & -- & $<.05$ & -- \\
\hline $\mathrm{CH}-4297$ & 19921001 & $<.01$ & -- & $<.01$ & $<.050$ & -- & $<.05$ & -- \\
\hline $\mathrm{CH}-4806$ & 19940628 & $<.01$ & -- & $<.01$ & $<.050$ & -- & $<.05$ & -- \\
\hline $\mathrm{CH}-4931$ & 19940721 & -- & $<0.05$ & -- & $<.018$ & -- & -- & -- \\
\hline $\mathrm{CH}-4933$ & 19940714 & -- & $<.05$ & -- & $<.018$ & -- & -- & -- \\
\hline $\mathrm{CH}-5420$ & 19980615 & -- & -- & -- & $<.018$ & -- & -- & -- \\
\hline $\mathrm{CH}-5421$ & 19980615 & -- & -- & -- & $<.018$ & -- & -- & -- \\
\hline $\mathrm{CH}-5423$ & 19980616 & -- & -- & -- & $<.018$ & -- & -- & -- \\
\hline $\mathrm{CH}-5424$ & 19980624 & -- & -- & -- & $<.018$ & -- & -- & -- \\
\hline $\mathrm{CH}-5425$ & 19980701 & -- & -- & -- & $<.018$ & -- & -- & -- \\
\hline $\mathrm{CH}-5426$ & 19981105 & -- & -- & -- & $<.018$ & -- & -- & -- \\
\hline $\mathrm{CH}-5428$ & 19981103 & -- & -- & -- & $<.018$ & -- & -- & -- \\
\hline $\mathrm{CH}-5430$ & 19980707 & -- & -- & -- & $<.018$ & -- & -- & -- \\
\hline $\mathrm{CH}-5431$ & 19980707 & -- & -- & -- & $<.018$ & -- & -- & -- \\
\hline $\mathrm{CH}-5432$ & 19980714 & -- & -- & -- & $<.018$ & -- & -- & -- \\
\hline $\mathrm{CH}-5433$ & 19980714 & -- & -- & -- & $<.018$ & -- & -- & -- \\
\hline $\mathrm{CH}-5434$ & 19980715 & -- & -- & -- & $<.018$ & -- & -- & -- \\
\hline $\mathrm{CH}-5437$ & 19981118 & -- & -- & -- & $<.018$ & -- & -- & -- \\
\hline $\mathrm{CH}-5439$ & 19981116 & -- & -- & -- & $<.018$ & -- & -- & -- \\
\hline $\mathrm{CH}-5440$ & 19981104 & -- & -- & -- & $<.018$ & -- & -- & -- \\
\hline $\mathrm{CH}-5442$ & 19981124 & -- & -- & -- & $<.018$ & -- & -- & -- \\
\hline $\mathrm{CH}-5443$ & 19981112 & -- & -- & -- & $<.018$ & -- & -- & -- \\
\hline $\mathrm{CH}-5450$ & 20000911 & -- & -- & -- & $<.018$ & -- & -- & -- \\
\hline $\mathrm{CH}-5470$ & 19960822 & -- & -- & -- & $<.018$ & -- & -- & -- \\
\hline CH-5476 & 19960904 & $<.01$ & -- & -- & -- & -- & -- & -- \\
\hline $\mathrm{CH}-5477$ & 19960904 & -- & -- & -- & -- & -- & -- & -- \\
\hline $\mathrm{CE}$ Ae 8 & 19981028 & -- & -- & -- & $<.018$ & -- & -- & -- \\
\hline CE Ae 9 & 19981026 & -- & -- & -- & $<.018$ & -- & -- & -- \\
\hline CE Ae 13 & 19981203 & -- & -- & -- & $<.018$ & & & \\
\hline
\end{tabular}


Table 21. Results of laboratory analyses for pesticides in ground water, Big Elk Creek Basin, Pennsylvania and Maryland-Continued

\begin{tabular}{|c|c|c|c|c|c|c|c|c|}
\hline $\begin{array}{c}\text { Well- } \\
\text { identification } \\
\text { number }\end{array}$ & $\begin{array}{l}\text { Date of } \\
\text { sample }\end{array}$ & $\begin{array}{c}\text { Pronamide, } \\
\text { total }\end{array}$ & $\begin{array}{l}\text { Propachlor, } \\
\text { dissolved }\end{array}$ & $\begin{array}{l}\text { Propanil, } \\
\text { dissolved }\end{array}$ & $\begin{array}{l}\text { Propargite, } \\
\text { dissolved }\end{array}$ & $\begin{array}{l}\text { Propazine, } \\
\text { dissolved }\end{array}$ & $\begin{array}{c}\text { Propazine, } \\
\text { total }\end{array}$ & $\begin{array}{c}\text { Silvex, } \\
\text { dissolved }\end{array}$ \\
\hline $\mathrm{CH}-75$ & 19900823 & -- & -- & -- & -- & -- & $<0.1$ & -- \\
\hline $\mathrm{CH}-1720$ & 19921001 & -- & -- & -- & -- & $<0.05$ & -- & -- \\
\hline $\mathrm{CH}-1720$ & 19930610 & -- & -- & -- & -- & -- & -- & -- \\
\hline $\mathrm{CH}-1735$ & 20000906 & $<0.003$ & $<0.0007$ & $<0.004$ & $<0.013$ & -- & -- & -- \\
\hline $\mathrm{CH}-2186$ & 19930818 & $<.003$ & $<.007$ & $<.004$ & $<.013$ & -- & -- & -- \\
\hline CH-2439 & 19810817 & -- & -- & -- & -- & -- & -- & -- \\
\hline $\mathrm{CH}-2440$ & 19810817 & -- & -- & -- & -- & -- & -- & -- \\
\hline $\mathrm{CH}-2459$ & 19820804 & -- & -- & -- & -- & -- & -- & -- \\
\hline $\mathrm{CH}-2460$ & 19820804 & -- & -- & -- & -- & -- & -- & -- \\
\hline $\mathrm{CH}-2461$ & 19820804 & -- & -- & -- & -- & -- & -- & -- \\
\hline $\mathrm{CH}-2461$ & 19830707 & -- & -- & -- & -- & -- & $<.1$ & -- \\
\hline $\mathrm{CH}-2461$ & 19950808 & $<.003$ & $<.007$ & $<.004$ & $<.013$ & -- & -- & -- \\
\hline $\mathrm{CH}-3316$ & 19880808 & -- & -- & -- & -- & -- & $<.1$ & -- \\
\hline $\mathrm{CH}-3316$ & 19900906 & -- & -- & -- & -- & -- & -- & -- \\
\hline $\mathrm{CH}-3317$ & 19880808 & -- & -- & -- & -- & -- & $<.1$ & -- \\
\hline $\mathrm{CH}-4126$ & 19910807 & -- & -- & -- & -- & $<.05$ & -- & -- \\
\hline CH-4297 & 19921001 & -- & -- & -- & -- & $<.05$ & -- & -- \\
\hline $\mathrm{CH}-4806$ & 19940628 & -- & -- & -- & -- & $<.05$ & -- & -- \\
\hline $\mathrm{CH}-4931$ & 19940721 & $<.003$ & $<.007$ & $<.004$ & $<.013$ & -- & -- & $<0.02$ \\
\hline $\mathrm{CH}-4933$ & 19940714 & $<.003$ & $<.007$ & $<.004$ & $<.013$ & -- & -- & $<.02$ \\
\hline $\mathrm{CH}-5420$ & 19980615 & $<.003$ & $<.007$ & $<.004$ & $<.013$ & -- & -- & -- \\
\hline $\mathrm{CH}-5421$ & 19980615 & $<.003$ & $<.007$ & $<.004$ & $<.013$ & -- & -- & -- \\
\hline $\mathrm{CH}-5423$ & 19980616 & $<.003$ & $<.007$ & $<.004$ & $<.013$ & -- & -- & -- \\
\hline $\mathrm{CH}-5424$ & 19980624 & $<.003$ & $<.007$ & $<.004$ & $<.013$ & -- & -- & -- \\
\hline $\mathrm{CH}-5425$ & 19980701 & $<.003$ & $<.007$ & $<.004$ & $<.013$ & -- & -- & -- \\
\hline $\mathrm{CH}-5426$ & 19981105 & $<.003$ & $<.007$ & $<.004$ & $<.013$ & -- & -- & -- \\
\hline $\mathrm{CH}-5428$ & 19981103 & $<.003$ & $<.007$ & $<.004$ & $<.013$ & -- & -- & -- \\
\hline $\mathrm{CH}-5430$ & 19980707 & $<.003$ & $<.007$ & $<.004$ & $<.013$ & -- & -- & -- \\
\hline $\mathrm{CH}-5431$ & 19980707 & $<.003$ & $<.007$ & $<.004$ & $<.013$ & -- & -- & -- \\
\hline $\mathrm{CH}-5432$ & 19980714 & $<.003$ & $<.007$ & $<.004$ & $<.013$ & -- & -- & -- \\
\hline $\mathrm{CH}-5433$ & 19980714 & $<.003$ & $<.007$ & $<.004$ & $<.013$ & -- & -- & -- \\
\hline $\mathrm{CH}-5434$ & 19980715 & $<.003$ & $<.007$ & $<.004$ & $<.013$ & -- & -- & -- \\
\hline $\mathrm{CH}-5437$ & 19981118 & $<.003$ & $<.007$ & $<.004$ & $<.013$ & -- & -- & -- \\
\hline $\mathrm{CH}-5439$ & 19981116 & $<.003$ & $<.007$ & $<.004$ & $<.013$ & -- & -- & -- \\
\hline $\mathrm{CH}-5440$ & 19981104 & $<.003$ & $<.007$ & $<.004$ & $<.013$ & -- & -- & -- \\
\hline $\mathrm{CH}-5442$ & 19981124 & $<.003$ & $<.007$ & $<.004$ & $<.013$ & -- & -- & -- \\
\hline $\mathrm{CH}-5443$ & 19981112 & $<.003$ & $<.007$ & $<.004$ & $<.013$ & -- & -- & -- \\
\hline $\mathrm{CH}-5450$ & 20000911 & $<.003$ & $<.007$ & $<.004$ & $<.013$ & -- & -- & -- \\
\hline $\mathrm{CH}-5470$ & 19960822 & $<.003$ & $<.007$ & $<.004$ & $<.013$ & -- & -- & -- \\
\hline CH-5476 & 19960904 & -- & -- & -- & -- & -- & -- & -- \\
\hline $\mathrm{CH}-5477$ & 19960904 & -- & -- & -- & -- & -- & -- & -- \\
\hline CE Ae 8 & 19981028 & $<.003$ & $<.007$ & $<.004$ & $<.013$ & -- & -- & -- \\
\hline CE Ae 9 & 19981026 & $<.003$ & $<.007$ & $<.004$ & $<.013$ & -- & -- & -- \\
\hline CE Ae 13 & 19981203 & $<.003$ & $<.007$ & $<.004$ & $<.013$ & -- & -- & -- \\
\hline
\end{tabular}


Table 21. Results of laboratory analyses for pesticides in ground water, Big Elk Creek Basin, Pennsylvania and Maryland-Continued

\begin{tabular}{|c|c|c|c|c|c|c|c|c|}
\hline $\begin{array}{c}\text { Well- } \\
\text { identification } \\
\text { number }\end{array}$ & $\begin{array}{l}\text { Date of } \\
\text { sample }\end{array}$ & $\begin{array}{l}\text { Silvex, } \\
\text { total }\end{array}$ & $\begin{array}{l}\text { Simazine, } \\
\text { dissolved }\end{array}$ & $\begin{array}{c}\text { Simazine, } \\
\text { total }\end{array}$ & $\begin{array}{c}\text { Tebuthiuron, } \\
\text { dissolved }\end{array}$ & $\begin{array}{l}\text { Terbacil, } \\
\text { dissolved }\end{array}$ & $\begin{array}{l}\text { Terbufos, } \\
\text { dissolved }\end{array}$ & $\begin{array}{c}\text { Thiobencarb, } \\
\text { dissolved }\end{array}$ \\
\hline $\mathrm{CH}-75$ & 19900823 & -- & -- & $<0.1$ & -- & -- & -- & -- \\
\hline $\mathrm{CH}-1720$ & 19921001 & -- & $<0.050$ & -- & -- & -- & -- & -- \\
\hline $\mathrm{CH}-1720$ & 19930610 & -- & -- & -- & -- & -- & -- & -- \\
\hline $\mathrm{CH}-1735$ & 20000906 & -- & $<.005$ & -- & $<0.010$ & $<0.007$ & $<0.013$ & $<0.002$ \\
\hline $\mathrm{CH}-2186$ & 19930818 & -- & $<.005$ & -- & .034 & $<.007$ & $<.013$ & $<.002$ \\
\hline $\mathrm{CH}-2439$ & 19810817 & -- & -- & -- & -- & -- & -- & -- \\
\hline $\mathrm{CH}-2440$ & 19810817 & -- & -- & -- & -- & -- & -- & -- \\
\hline $\mathrm{CH}-2459$ & 19820804 & -- & -- & -- & -- & -- & -- & -- \\
\hline $\mathrm{CH}-2460$ & 19820804 & -- & -- & -- & -- & -- & -- & -- \\
\hline $\mathrm{CH}-2461$ & 19820804 & -- & -- & -- & -- & -- & -- & -- \\
\hline $\mathrm{CH}-2461$ & 19830707 & $<0.01$ & -- & $<.1$ & -- & -- & -- & -- \\
\hline $\mathrm{CH}-2461$ & 19950808 & -- & .041 & -- & $<.010$ & $<.007$ & $<.013$ & $<.002$ \\
\hline $\mathrm{CH}-3316$ & 19880808 & -- & -- & $<.1$ & -- & -- & -- & -- \\
\hline $\mathrm{CH}-3316$ & 19900906 & -- & -- & -- & -- & -- & -- & -- \\
\hline $\mathrm{CH}-3317$ & 19880808 & $<.01$ & -- & $<.1$ & -- & -- & -- & -- \\
\hline $\mathrm{CH}-4126$ & 19910807 & $<.01$ & $<.050$ & & -- & -- & -- & -- \\
\hline $\mathrm{CH}-4297$ & 19921001 & $<.01$ & $<.050$ & -- & -- & -- & -- & -- \\
\hline $\mathrm{CH}-4806$ & 19940628 & $<.01$ & $<.050$ & -- & -- & -- & -- & -- \\
\hline $\mathrm{CH}-4931$ & 19940721 & -- & $<.005$ & -- & $<.010$ & $<.007$ & $<.013$ & $<.002$ \\
\hline $\mathrm{CH}-4933$ & 19940714 & -- & $<.005$ & -- & $<.010$ & $<.007$ & $<.013$ & $<.002$ \\
\hline $\mathrm{CH}-5420$ & 19980615 & -- & $.003 \mathrm{E}$ & -- & $<.010$ & $<.007$ & $<.013$ & $<.002$ \\
\hline $\mathrm{CH}-5421$ & 19980615 & -- & $<.005$ & -- & $<.010$ & $<.007$ & $<.013$ & $<.002$ \\
\hline $\mathrm{CH}-5423$ & 19980616 & -- & $.003 \mathrm{E}$ & -- & $<.010$ & $<.007$ & $<.013$ & $<.002$ \\
\hline $\mathrm{CH}-5424$ & 19980624 & -- & $<.005$ & -- & $<.010$ & $<.007$ & $<.013$ & $<.002$ \\
\hline $\mathrm{CH}-5425$ & 19980701 & -- & $<.005$ & -- & $<.010$ & $<.007$ & $<.013$ & $<.002$ \\
\hline $\mathrm{CH}-5426$ & 19981105 & -- & $<.005$ & -- & $<.010$ & $<.007$ & $<.013$ & $<.002$ \\
\hline $\mathrm{CH}-5428$ & 19981103 & -- & $<.005$ & -- & $<.010$ & $<.007$ & $<.013$ & $<.002$ \\
\hline $\mathrm{CH}-5430$ & 19980707 & -- & .026 & -- & $<.010$ & $<.007$ & $<.013$ & $<.002$ \\
\hline $\mathrm{CH}-5431$ & 19980707 & -- & $<.005$ & -- & $<.010$ & $<.007$ & $<.013$ & $<.002$ \\
\hline $\mathrm{CH}-5432$ & 19980714 & -- & $<.005$ & -- & $<.010$ & $<.007$ & $<.013$ & $<.002$ \\
\hline $\mathrm{CH}-5433$ & 19980714 & -- & $<.005$ & -- & $<.010$ & $<.007$ & $<.013$ & $<.002$ \\
\hline $\mathrm{CH}-5434$ & 19980715 & -- & $<.005$ & -- & $<.010$ & $<.007$ & $<.013$ & $<.002$ \\
\hline $\mathrm{CH}-5437$ & 19981118 & -- & $<.005$ & -- & $<.010$ & $<.007$ & $<.013$ & $<.002$ \\
\hline $\mathrm{CH}-5439$ & 19981116 & -- & $<.005$ & -- & $<.010$ & $<.007$ & $<.013$ & $<.002$ \\
\hline $\mathrm{CH}-5440$ & 19981104 & -- & $<.005$ & -- & $<.010$ & $<.007$ & $<.013$ & $<.002$ \\
\hline $\mathrm{CH}-5442$ & 19981124 & -- & $<.005$ & -- & $<.010$ & $<.007$ & $<.013$ & $<.002$ \\
\hline $\mathrm{CH}-5443$ & 19981112 & -- & $<.005$ & -- & $<.010$ & $<.007$ & $<.013$ & $<.002$ \\
\hline $\mathrm{CH}-5450$ & 20000911 & -- & $<.005$ & -- & $<.010$ & $<.007$ & $<.013$ & $<.002$ \\
\hline $\mathrm{CH}-5470$ & 19960822 & -- & $<.005$ & -- & $<.010$ & $<.007$ & $<.013$ & $<.002$ \\
\hline $\mathrm{CH}-5476$ & 19960904 & -- & -- & -- & -- & -- & -- & -- \\
\hline $\mathrm{CH}-5477$ & 19960904 & -- & -- & -- & -- & -- & -- & -- \\
\hline CE Ae 8 & 19981028 & -- & $<.036$ & -- & $<.010$ & $<.007$ & $<.013$ & $.003 \mathrm{E}$ \\
\hline CE Ae 9 & 19981026 & -- & $<.005$ & -- & $<.010$ & $<.007$ & $<.013$ & $<.002$ \\
\hline CE Ae 13 & 19981203 & -- & .011 & -- & $<.010$ & $<.007$ & $<.013$ & $<.002$ \\
\hline
\end{tabular}


Table 21. Results of laboratory analyses for pesticides in ground water, Big Elk Creek Basin, Pennsylvania and Maryland-Continued

\begin{tabular}{|c|c|c|c|c|c|c|c|c|}
\hline $\begin{array}{c}\text { Well- } \\
\text { identification } \\
\text { number }\end{array}$ & $\begin{array}{l}\text { Date of } \\
\text { sample }\end{array}$ & $\begin{array}{l}\text { Toxaphene, } \\
\text { total }\end{array}$ & $\begin{array}{l}\text { Triallate, } \\
\text { dissolved }\end{array}$ & $\begin{array}{l}\text { Trifluralin, } \\
\text { dissolved }\end{array}$ & $\begin{array}{l}\text { Trifluralin, } \\
\text { total }\end{array}$ & $\begin{array}{c}\text { 2,6-Diethylaniline, } \\
\text { dissolved }\end{array}$ & $\begin{array}{l}\text { 2,4,5-T, } \\
\text { dissolved }\end{array}$ & $\begin{array}{l}2,4,5-\mathrm{T} \\
\text { total }\end{array}$ \\
\hline $\mathrm{CH}-75$ & 19900823 & $<1$ & -- & -- & $<0.1$ & -- & -- & -- \\
\hline $\mathrm{CH}-1720$ & 19921001 & -- & -- & -- & -- & -- & -- & -- \\
\hline $\mathrm{CH}-1720$ & 19930610 & $<1$ & -- & -- & -- & -- & -- & -- \\
\hline $\mathrm{CH}-1735$ & 20000906 & -- & $<0.001$ & $<0.002$ & -- & $<0.003$ & -- & -- \\
\hline $\mathrm{CH}-2186$ & 19930818 & $<1$ & $<.001$ & $<.002$ & -- & $<.003$ & -- & -- \\
\hline $\mathrm{CH}-2439$ & 19810817 & $<1$ & -- & -- & -- & -- & -- & -- \\
\hline $\mathrm{CH}-2440$ & 19810817 & $<1$ & -- & -- & -- & -- & -- & -- \\
\hline $\mathrm{CH}-2459$ & 19820804 & $<1$ & -- & -- & -- & -- & -- & -- \\
\hline $\mathrm{CH}-2460$ & 19820804 & $<1$ & -- & -- & -- & -- & -- & -- \\
\hline $\mathrm{CH}-2461$ & 19820804 & $<1$ & -- & -- & -- & -- & -- & -- \\
\hline $\mathrm{CH}-2461$ & 19830707 & -- & -- & -- & -- & -- & -- & $<0.01$ \\
\hline $\mathrm{CH}-2461$ & 19950808 & $<1$ & $<.001$ & $.001 \mathrm{E}$ & -- & $<.003$ & -- & -- \\
\hline $\mathrm{CH}-3316$ & 19880808 & $<1$ & -- & -- & $<.1$ & -- & -- & -- \\
\hline $\mathrm{CH}-3316$ & 19900906 & -- & -- & -- & -- & -- & -- & -- \\
\hline $\mathrm{CH}-3317$ & 19880808 & $<1$ & -- & -- & $<.1$ & -- & -- & $<.01$ \\
\hline $\mathrm{CH}-4126$ & 19910807 & $<1$ & -- & -- & -- & -- & -- & $<.01$ \\
\hline $\mathrm{CH}-4297$ & 19921001 & $<1$ & -- & -- & -- & -- & -- & $<.01$ \\
\hline $\mathrm{CH}-4806$ & 19940628 & $<1$ & -- & -- & -- & -- & -- & $<.01$ \\
\hline $\mathrm{CH}-4931$ & 19940721 & -- & $<.001$ & $<.002$ & -- & $<.003$ & $<0.04$ & -- \\
\hline $\mathrm{CH}-4933$ & 19940714 & -- & $<.001$ & $<.002$ & -- & $<.003$ & $<.04$ & -- \\
\hline $\mathrm{CH}-5420$ & 19980615 & -- & $<.001$ & $<.002$ & -- & $<.003$ & -- & -- \\
\hline $\mathrm{CH}-5421$ & 19980615 & -- & $<.001$ & $<.002$ & -- & $<.003$ & -- & -- \\
\hline $\mathrm{CH}-5423$ & 19980616 & -- & $<.001$ & $<.002$ & -- & $<.003$ & -- & -- \\
\hline $\mathrm{CH}-5424$ & 19980624 & -- & $<.001$ & $<.002$ & -- & $<.003$ & -- & -- \\
\hline $\mathrm{CH}-5425$ & 19980701 & -- & $<.001$ & $<.002$ & -- & $<.003$ & -- & -- \\
\hline $\mathrm{CH}-5426$ & 19981105 & -- & $<.001$ & $<.002$ & -- & $<.003$ & -- & -- \\
\hline $\mathrm{CH}-5428$ & 19981103 & -- & $<.001$ & $<.002$ & -- & $<.003$ & -- & -- \\
\hline $\mathrm{CH}-5430$ & 19980707 & -- & $<.001$ & $<.002$ & -- & $<.003$ & -- & -- \\
\hline $\mathrm{CH}-5431$ & 19980707 & -- & $<.001$ & $<.002$ & -- & $<.003$ & -- & -- \\
\hline $\mathrm{CH}-5432$ & 19980714 & -- & $<.001$ & $<.002$ & -- & $<.003$ & -- & -- \\
\hline $\mathrm{CH}-5433$ & 19980714 & -- & $<.001$ & $<.002$ & -- & $<.003$ & -- & -- \\
\hline $\mathrm{CH}-5434$ & 19980715 & -- & $<.001$ & $<.002$ & -- & $<.003$ & -- & -- \\
\hline $\mathrm{CH}-5437$ & 19981118 & -- & $<.001$ & $<.002$ & -- & $<.003$ & -- & -- \\
\hline $\mathrm{CH}-5439$ & 19981116 & -- & $<.001$ & $<.002$ & -- & $<.003$ & -- & -- \\
\hline $\mathrm{CH}-5440$ & 19981104 & -- & $<.001$ & $<.002$ & -- & $<.003$ & -- & -- \\
\hline $\mathrm{CH}-5442$ & 19981124 & -- & $<.001$ & $<.002$ & -- & $<.003$ & -- & -- \\
\hline $\mathrm{CH}-5443$ & 19981112 & -- & $<.001$ & $<.002$ & -- & -- & -- & -- \\
\hline $\mathrm{CH}-5450$ & 20000911 & -- & $<.001$ & $<.002$ & -- & $<.003$ & -- & -- \\
\hline $\mathrm{CH}-5470$ & 19960822 & $<1$ & $<.001$ & $<.002$ & -- & $<.003$ & -- & -- \\
\hline $\mathrm{CH}-5476$ & 19960904 & $<1$ & -- & -- & -- & -- & -- & -- \\
\hline $\mathrm{CH}-5477$ & 19960904 & $<1$ & -- & -- & -- & -- & -- & -- \\
\hline CE Ae 8 & 19981028 & -- & $<.001$ & $<.002$ & -- & $<.003$ & -- & -- \\
\hline CE Ae 9 & 19981026 & -- & $<.001$ & $<.002$ & -- & $<.003$ & -- & -- \\
\hline CE Ae 13 & 19981203 & -- & $<.001$ & $<.002$ & -- & $<.003$ & -- & -- \\
\hline
\end{tabular}


Table 21. Results of laboratory analyses for pesticides in ground water, Big Elk Creek Basin, Pennsylvania and Maryland-Continued

\begin{tabular}{|c|c|c|c|c|}
\hline $\begin{array}{c}\text { Well- } \\
\text { identification } \\
\text { number }\end{array}$ & $\begin{array}{l}\text { Date of } \\
\text { sample }\end{array}$ & $\begin{array}{c}\text { 2,4-D, } \\
\text { total }\end{array}$ & $\begin{array}{c}\text { 2,4-D, } \\
\text { dissolved }\end{array}$ & $\begin{array}{c}2,4-D P \\
\text { total }\end{array}$ \\
\hline $\mathrm{CH}-75$ & 19900823 & -- & -- & -- \\
\hline $\mathrm{CH}-1720$ & 19921001 & -- & -- & -- \\
\hline $\mathrm{CH}-1720$ & 19930610 & -- & -- & -- \\
\hline $\mathrm{CH}-1735$ & 20000906 & -- & -- & -- \\
\hline $\mathrm{CH}-2186$ & 19930818 & -- & -- & -- \\
\hline $\mathrm{CH}-2439$ & 19810817 & -- & -- & -- \\
\hline $\mathrm{CH}-2440$ & 19810817 & -- & -- & -- \\
\hline $\mathrm{CH}-2459$ & 19820804 & -- & -- & -- \\
\hline $\mathrm{CH}-2460$ & 19820804 & -- & -- & -- \\
\hline $\mathrm{CH}-2461$ & 19820804 & -- & -- & -- \\
\hline $\mathrm{CH}-2461$ & 19830707 & $<0.01$ & -- & $<0.01$ \\
\hline $\mathrm{CH}-2461$ & 19950808 & -- & -- & -- \\
\hline $\mathrm{CH}-3316$ & 19880808 & -- & -- & -- \\
\hline $\mathrm{CH}-3316$ & 19900906 & -- & -- & -- \\
\hline $\mathrm{CH}-3317$ & 19880808 & $<.01$ & -- & $<.01$ \\
\hline $\mathrm{CH}-4126$ & 19910807 & $<.01$ & -- & $<.01$ \\
\hline $\mathrm{CH}-4297$ & 19921001 & $<.01$ & -- & $<.01$ \\
\hline $\mathrm{CH}-4806$ & 19940628 & $<.01$ & -- & $<.01$ \\
\hline $\mathrm{CH}-4931$ & 19940721 & -- & $<0.04$ & -- \\
\hline $\mathrm{CH}-4933$ & 19940714 & -- & $<.04$ & -- \\
\hline $\mathrm{CH}-5420$ & 19980615 & -- & & -- \\
\hline $\mathrm{CH}-5421$ & 19980615 & -- & -- & -- \\
\hline $\mathrm{CH}-5423$ & 19980616 & -- & -- & -- \\
\hline $\mathrm{CH}-5424$ & 19980624 & -- & -- & -- \\
\hline $\mathrm{CH}-5425$ & 19980701 & -- & -- & -- \\
\hline CH-5426 & 19981105 & -- & -- & -- \\
\hline CH-5428 & 19981103 & -- & -- & -- \\
\hline $\mathrm{CH}-5430$ & 19980707 & -- & -- & -- \\
\hline $\mathrm{CH}-5431$ & 19980707 & -- & -- & -- \\
\hline CH-5432 & 19980714 & -- & -- & -- \\
\hline $\mathrm{CH}-5433$ & 19980714 & -- & -- & -- \\
\hline $\mathrm{CH}-5434$ & 19980715 & -- & -- & -- \\
\hline $\mathrm{CH}-5437$ & 19981118 & -- & -- & -- \\
\hline $\mathrm{CH}-5439$ & 19981116 & -- & -- & -- \\
\hline $\mathrm{CH}-5440$ & 19981104 & -- & -- & -- \\
\hline CH-5442 & 19981124 & -- & -- & -- \\
\hline $\mathrm{CH}-5443$ & 19981112 & -- & -- & -- \\
\hline $\mathrm{CH}-5450$ & 20000911 & -- & -- & -- \\
\hline $\mathrm{CH}-5470$ & 19960822 & -- & -- & -- \\
\hline $\mathrm{CH}-5476$ & 19960904 & -- & -- & -- \\
\hline $\mathrm{CH}-5477$ & 19960904 & -- & -- & -- \\
\hline CE Ae 8 & 19981028 & -- & -- & -- \\
\hline CE Ae 9 & 19981026 & -- & -- & -- \\
\hline $\mathrm{CE} \mathrm{Ae} 13$ & 19981203 & -- & -- & -- \\
\hline
\end{tabular}

